UNIVERSIDADE DE SÃO PAULO INSTITUTO DE PSICOLOGIA

GUILHERME GIBRAN POGIBIN

\title{
MEMÓRIAS DE METALÚRGICOS GREVISTAS DO ABC PAULISTA
}




\section{GUILHERME GIBRAN POGIBIN}

\section{MEMÓRIAS DE METALÚRGICOS GREVISTAS DO ABC PAULISTA}

Dissertação de mestrado apresentada ao Instituto de Psicologia da Universidade de São Paulo como parte dos requisitos para a obtenção do título de Mestre em Psicologia.

Área de concentração: Psicologia Social e do Trabalho.

Orientadora: Profa. Dra. Ecléa Bosi

São Paulo 
AUTORIZO A REPRODUÇÃO E DIVULGAÇÃO TOTAL OU PARCIAL DESTE TRABALHO, POR QUALQUER MEIO CONVENCIONAL OU ELETRÔNICO, PARA FINS DE ESTUDO E PESQUISA, DESDE QUE CITADA A FONTE.

Catalogação na publicação

Serviço de Biblioteca e Documentação

Instituto de Psicologia da Universidade de São Paulo

Pogibin, Guilherme Gibran.

Memórias de metalúgicos grevistas do ABC Paulista / Guilherme Gibran Pogibin; orientadora Ecléa Bosi. - São Paulo, 2009.

$258 \mathrm{p}$.

Dissertação (Mestrado - Programa de Pós-Graduação em Psicologia. Área de Concentração: Psicologia Social e do Trabalho) Instituto de Psicologia da Universidade de São Paulo.

1. Psicologia Social 2. Memória social 3. Greves 4. Operários 5. Sindicalismo 6. Movimentos sociais I. Título. 
Guilherme Gibran Pogibin

Memória de metalúrgicos grevistas do ABC Paulista

Dissertação de mestrado apresentada ao Instituto de Psicologia da Universidade de São Paulo como parte dos requisitos para a obtenção do título de Mestre em Psicologia.

Área de concentração:

Psicologia Social e do Trabalho.

Orientadora:

Profa. Dra. Ecléa Bosi

BANCA EXAMINADORA

Prof. Dr.:

Instituição:

Assinatura:

Prof. Dr.:

Instituição: Assinatura:

Prof. Dr.:

Instituição: Assinatura:

Dissertação apresentada e aprovada em: 
Para Suely e Alexander, sem os quais eu seria nada.

Para Katia, com a qual sou tudo. 


\section{AGRADECIMENTOS}

À Ecléa Bosi, por tudo que me ofereceu neste percurso: atenção, inspiração, sensibilidade, gentileza, conselhos e ensinamentos. Uma pessoa preciosa, a quem serei eternamente grato por ter me acolhido nesta pesquisa.

Ao Zeca Moura, pelas melhores aulas que tive na minha vida. Sua paixão pelo conhecimento é realmente inspiradora.

À Maria Célia Paoli, pelas importantes contribuições feitas durante o exame de qualificação.

À Heloísa Martins, por ter aceito compor a banca na defesa desta dissertação.

Aos seguintes professores e supervisores que, de alguma forma, contribuíram marcantemente para a minha formação profissional e política e me inspiraram na realização deste trabalho: Leny Sato, Malu Schmidt, Marilene Proença, Lígia Amaral (in memorian), Marcelo Afonso Ribeiro, Iran Jácome Rodrigues, Maria Helena Patto, equipe do CPAT (especialmente Tatiana Neves), Gê Eisenlohr e Adriana Marcondes Machado.

À Nalva e à Cecília, pelo apoio e simpatia.

Aos entrevistados desta pesquisa: Adão, Reinaldo, Wilson, Dimas, Nelson e Rafael. Mais que entrevistas, me deram lições de vida. Também à Nádia, por me apresentar ao Adão, e ao Zé Fernandes, por me receber na Associação dos Metalúrgicos Aposentados.

A todos aqueles com quem participei da militância estudantil, nas diferentes instâncias e entidades: Centro Acadêmico Iara Iavelberg, Conselhos Estadual e Nacional de Estudantes de Psicologia, Diretório Central dos Estudantes Alexandre Vannuchi Leme, BOCA (Boletim do Centro Acadêmico), representação discente da graduação e da pós-graduação, e Cursinho Psico-USP. Também a todos os estudantes, funcionários e professores com quem convivi e aprendi muito durante as greves da USP. 
À "equipe" do corredor do Instituto de Psicologia, especialmente ao Jairo, à Oriana, ao Zé e à Marlene, pelos altos papos e cafés.

À Katia, o grande amor de minha vida. Pela dedicação, carinho, companheirismo, paixão, conversas, ajudas e mimo. Em minha vida, o elo entre passado, presente e futuro. Os sonhos que alimentam nosso amor são bem nutritivos, além de terem um tempero delicioso.

Aos meus pais, Suely e Alexander, pelo amor e apoio incondicionais. Levarei sempre comigo os valores, ensinamentos e conselhos que me deram. Se estou me tornando mestre hoje é por conta dos mestres que tive em casa.

Aos meus irmãos, Christian e Juliana. Amor de irmão é aquele demonstrado nas brincadeiras, nas brigas, no cuidado e no sincero desejo de felicidade.

A toda Gibranzada (êêêêêêêê): Vô Zé, Vó Elza (in memorian), Zete, Marília, João Pedro, Jorge, Solange, Flora, Mário, Leo, Lu, Artur, Rapha, Soninha, Camila, Mark, Zito, Dal, Mariana, Laura, Luiza e Fábio. Família de doidos que eu adoro.

Aos meus sogros, Valika e Helgo, pelo carinho, hospitalidade e apoio. Também ao Marko, à Priscila e ao Yure, que deram seu apoio, mesmo de longe.

Aos queridos amigos de ontem, de hoje e de sempre: Cláu, Bruno, Nina, Max, Lela, Alê, Naty, Danilo, Luís, Bruno, Renata, Ju Farah e Aninha. Cervejas, passeios, viagens e conversas que foram fundamentais durante este percurso.

Ao Kiko, companheiro de política, festança e Corinthians.

Ao Samir, veterano de psicologia e política, um exemplo para a militância.

Ao Ceará, mestre do forró e da vida.

À Lucila, pelo suporte em momentos tão difíceis.

Ao Marley, companheiro durante as duras horas de escrita. 
À Fabiana, pela revisão atenta deste trabalho.

Ao $\mathrm{CNPq}$, pelo financiamento da pesquisa. 


\section{RESUMO}

POGIBIN, G. G. Memórias de metalúrgicos grevistas do ABC Paulista. 2009. $258 \mathrm{f}$. Dissertação (Mestrado em Psicologia). Instituto de Psicologia, Universidade de São Paulo, São Paulo.

Os metalúrgicos da região do ABC Paulista sofreram, desde o golpe militar em 1964, de um lado, a repressão política que impossibilitava a organização dos trabalhadores, tanto sindical como grevista; e de outro, o arrocho salarial e a carestia, causados pela política econômica do governo que, nesta época, era quem determinava os índices de reajuste salarial. Paralelamente, durante a década de 70, o Sindicato dos Metalúrgicos de São Bernardo do Campo e Diadema, progressivamente, adotou um discurso de aproximação aos trabalhadores. Ainda, muitos movimentos populares se organizaram neste período na Grande São Paulo, articulando-se com os movimentos sindicais. Tais processos desencadearam uma série de greves de trabalhadores do setor metalúrgico no ABC Paulista, em um ciclo que começou em 1978 e se estendeu até meados da década de 80. As greves marcaram a fundação do que se chama hoje de "novo sindicalismo", além de ter raízes na fundação da CUT (Central Única dos Trabalhadores) e do PT (Partido dos Trabalhadores). A presente pesquisa tem por objetivo analisar, a partir de uma perspectiva psicossocial, a memória que trabalhadores metalúrgicos do ABC Paulista têm das greves, bem como dos processos que a antecederam. A psicologia social, ciência que foca o homem enquanto participante de grupos ou coletividades, que vive em companhia dos outros, é um campo do conhecimento adequado para a análise de fenômenos políticos, como foram as greves dos metalúrgicos do $\mathrm{ABC}$. $\mathrm{O}$ recurso à memória, por meio de depoimentos, traz pistas de como se deu a participação do trabalhador na greve, assim como da relação dele com as pessoas envolvidas (colegas, sindicalistas, patrões). Foram entrevistados cinco metalúrgicos que participaram das greves referidas, e um que não participou das greves, mas viveu o momento em que elas aconteceram na condição de trabalhador metalúrgico. Foram feitas entrevistas semi-dirigidas, que privilegiaram a narrativa dos fatos vividos. A análise das entrevistas foi feita seguindo uma linha qualitativa, e foi dividida em quatro eixos, expostos a seguir: 1) Sobre os significados das greves, estes apareceram de múltiplas formas. As greves apareceram relacionadas à violência, à conquista de direitos e ao resgate de uma dignidade perdida; 2) A partir dos depoimentos percebe-se uma construção coletiva das memórias das greves, principalmente em relação aos acontecimentos com participação de grande número de pessoas, como as grandes assembleias. Cada depoente, no entanto, destaca o que foi marcante para si. E as narrativas de acontecimentos que tiveram uma participação ativa do depoente têm importante destaque nas entrevistas; 3) Nas trajetórias de formação política dos grevistas aparece com destaque a importância do sindicato e dos movimentos sociais, como o ligado à Igreja Católica. A mediação de tais movimentos coletivos exerce papel fundamental na conscientização sobre a organização política e social relacionada às greves; e 4) $\mathrm{O}$ entrelaçamento temporal nos depoimentos mostra que é inevitável a comparação dos fatos lembrados do passado com o momento presente. As avaliações das consequências das greves no presente e as perspectivas políticas para o futuro estão ligadas ao que o trabalhador construiu como horizonte utópico.

Palavras-chave: Psicologia social. Memória social. Greves. Operários. Sindicalismo. Movimentos sociais. 


\section{ABSTRACT}

POGIBIN, G. G. Memories of striker metallurgists from the 'ABC Paulista' area. 2009. 258 p. Thesis (Master) - Instituto de Psicologia, Universidade de São Paulo, São Paulo.

The metallurgist workers from the $\mathrm{ABC}$ Paulista area suffered, since the military coup d'état in 1964, from on side, the political repression that made impossible the workers' oragnization (either concerning to labor unions or to calling strikes); from the other, the salary devaluation and the accentuated raise of prices, caused by the the economical politics of the government that, in those times, was who determined the salary rates. At the same time, during the 1970's, the São Bernardo do Campo and Diadema Metallurgist Labor Union, pregressively, adopted the intention to get closer to the workers' causes. Furthermore, many popular movements were organized during this period in the Great São Paulo, also tying up with the labor unions. Such processes leaded to a series of strikes of the metallurgist workers in the ABC Paulista, starting in 1978 and continiung until the mid 1980's. These strikes are related to the foundation of the so-called "New Labor-Unionism", as well as having straight relations with the foundation of the CUT (an important labor union central in Brazil) and the PT (Workers' Party). The aim of this research is to analyse, in a psycho-social perspective, the memories that the metallurgist workers have of these strikes, as well as the memories of the processes that preceded them. Social psychology, a science that has its focus on the person that takes part on groups or collectivities and that lives in company of others, is a suitable subject for the analysis of any political phenomena, such as the strikes. The support of the memory, brought up by the testimony of those who wer involved on the happenings, can give us clues of how the involvement of the workers in the strike were, as well as their relations with the people who took part on the processes (co-workers, union traders, bosses). Five metallurgist workers that took part os the strikes mentioned above were interviewed. Also one worker that didn't take part on the strikes, but was working in an metallurgist factory at that time, was interviewed. The interviews were based on the semi-direct method, focusing on the narration of the events. The analysis of the interviews was made according to a qualitative stream, and was divided in four axes, which are the following: 1) About the meaning of the strikes, these apperaed in multiple forms. They were related to violence, to the conquering of rights and to the rescue of a lost dignity; 2) A collective construction of the memory of the strikes was noticed, especially over the events that had a great amount of people involved, like some assemblies. Each interviewee, though, made stand out the facts that were most meaningful for himself. And the events that had an active participation of the interviewees had an important distinction on the narrations; 3) About the political upbringing of the strikers, the union trades and the social movements (such as the one linked to the catholic church) play an important role. The mediation of these movements are essential for bringing up the consciousness of the political and social organization related to the strikes; and 4) There is an inevitable interlacement between past and present during the remebering process. The judgement of the consequences of the strikes on the present and the political perspectives of the future are linked to how the worker constituted his utopic horizons.

Key words: Social Psychology. Social Memory. Strikes. Skilled Industrial Workers. Labor unions. Social Movements. 


\section{SUMÁRIO}

1 AS GREVES DOS METALURGICOS DO ABC............................ 12

1.1 Os antecedentes das greves........................................................... 12

1.2 As greves............................................................................ 18

2 O ESTUDO DA MEMÓRIA EM PSICOLOGIA SOCIAL................. 22

3 OBJETIVOS: AS PERGUNTAS QUE GUIAM A PESQUISA.......... 27

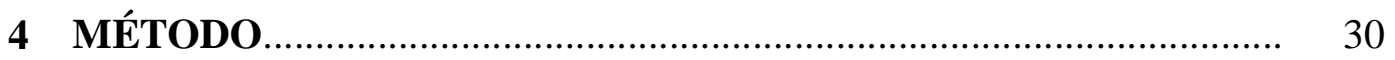

4.1 Entrevista semidirigida.......................................................... 30

4.2 Análise das entrevistas............................................................ 31

4.3 Os depoentes.......................................................................... 31

4.3.1 Adão............................................................................. 32

4.3.2 Associação dos Metalúrgicos Aposentados (AMA)............. 34

4.3.3 As diferenças entre as entrevistas..................................... 36

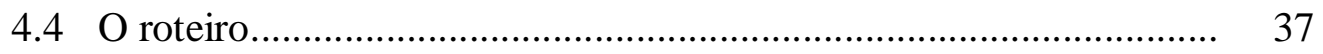

5 AS ENTREVISTAS ................................................................. 38

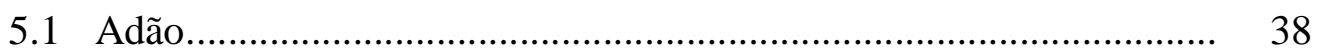

5.1.1 Parte 1 1.................................................................... 38

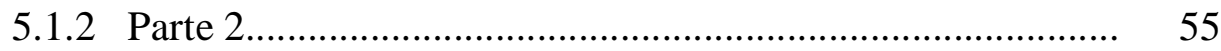

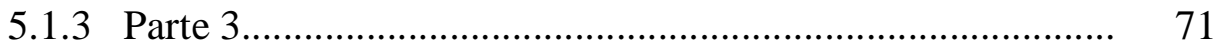

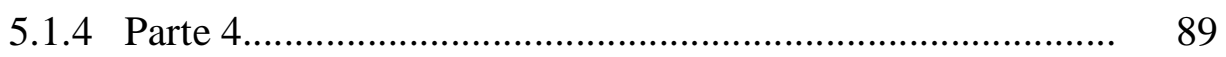

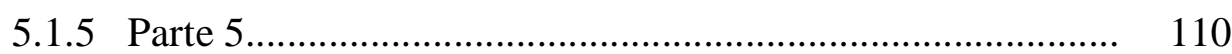

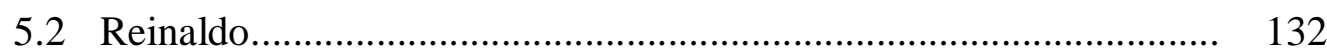

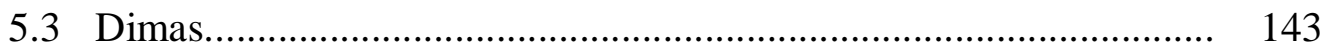

5.4 Wilson............................................................................ 151

5.5 Nelson............................................................................... 166

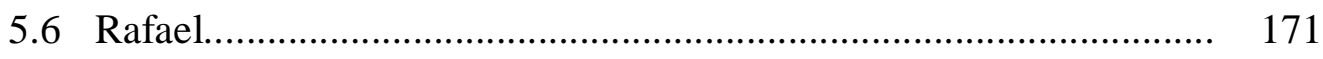

6 OS SIGNIFICADOS DA GREVE................................................ 181

6.1 As motivações para fazer greve................................................ 181

6.2 O grau de envolvimento de cada metalúrgico nas greves................ 186

6.3 Significado das greves: os temas a elas ligados............................. 190

6.3.1 A violência.......................................................................... 191

6.3.2 A criatividade........................................................... 194

6.3.3 A amizade.............................................................. 195 
6.3.4 A solidariedade.................................................................. 195

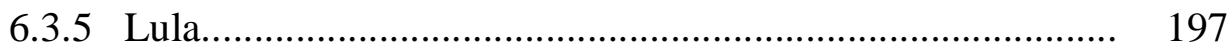

6.3.6 As conquistas.................................................................. 199

6.3.7 O resgate da dignidade......................................................... 199

7 MEMÓRIA COLETIVA/MEMÓRIA DA AÇÃO............................ 202

7.1 Memória das testemunhas............................................................ 202

7.2 Memória da ação.......................................................................... 207

7.2.1 Greve na fábrica............................................................ 208

7.2.2 Enfrentamento à chefia e à polícia...................................... 210

7.2.3 Solidariedade: o fundo de greve........................................ 212

7.2.4 Resistência na fábrica........................................................ 212

7.3 A revelação do agente da ação...................................................... 214

8 TRAJETÓRIAS DE FORMAÇÃO POLÍTICA.................................. 216

8.1 Trajetórias grevistas...................................................................... 216

8.1.1 A resistência no chão da fábrica.......................................... 216

8.1.2 Igreja Católica e movimentos de bairro................................. 218

8.1.3 Conversas informais........................................................ 220

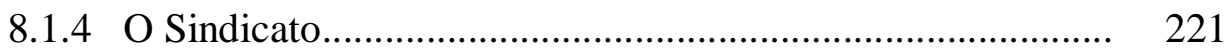

8.1.5 Treinamento para a greve.............................................. 225

8.1.6 As greves................................................................ 227

8.2 Greve e consciência política........................................................... 230

8.2.1 O salário....................................................................... 230

8.2.2 Direitos trabalhistas........................................................... 231

8.2.3 Consciência de classe......................................................... 235

9 TEMPO E MEMÓRIA: PASSADO, PRESENTE E FUTURO.......... 238

9.1 Comparações entre passado e presente............................................ 238

9.1.1 Sindicato e entidades políticas............................................. 238

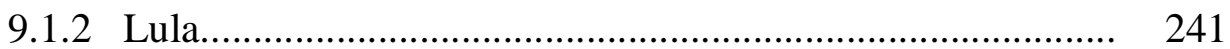

9.1.3 Situação social............................................................... 243

9.2 Temporalidade nos depoimentos: os caminhos da memória............ 245

9.3 Um elo entre o passado e o presente............................................. 247

9.4 Para finalizar, uma questão........................................................... 252

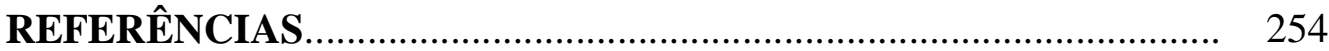

ANEXOS 


\section{AS GREVES DOS METALÚRGICOS DO ABC}

No ano de 1978 teve início uma onda grevista entre os metalúrgicos da chamada região do $\mathrm{ABC}$ Paulista. Muitos trabalhadores do ramo metalúrgico interromperam suas rotinas de produção em nome de melhores condições de vida e trabalho. Apontavam a insegurança, o grande número de acidentes no trabalho, a falta de higiene, o grande número de horas extras que eram forçados a fazer e o despotismo patronal, como justificativas para interromperem suas atividades. Reivindicavam também um reajuste salarial, denunciando o arrocho e a exploração do trabalhador. Esta onda grevista adentrou a década de 80. A organização dos metalúrgicos do $\mathrm{ABC}$ influenciou, em termos de greve e sindicato, os trabalhadores de muitos setores e de muitas regiões do Brasil, inaugurando o chamado Novo Sindicalismo (RODRIGUES, 1999).

A eclosão da greve em 1978 é consequência de uma série de fatores que atingiram diretamente a vida dos trabalhadores no pós 64 .

\subsection{Os antecedentes das greves}

A expansão econômica brasileira, principalmente no período pós 68 , que caracterizou o chamado "milagre econômico", baseou-se em medidas que favoreceram o investimento estrangeiro na indústria de bens duráveis (ANTUNES, 1992). A indústria automobilística teve lugar de destaque nesse processo; e a região do ABC configurava-se na época como um importante pólo industrial metalúrgico, principalmente no setor automobilístico.

Os padrões de acumulação de capital, neste setor (como em outros setores da indústria), apoiaram-se diretamente na desvalorização salarial dos operários. Esse tipo de medida permitia também a competitividade dos produtos brasileiros no mercado internacional. A perda salarial, ou a diminuição do valor real do salário, foi usada como estratégia tanto por parte de governo (que durante o período militar decidia sobre a política salarial), como por parte das empresas no sentido de acúmulo de capital (ANTUNES, 1992). 
As consequências da desvalorização dos salários na vida dos trabalhadores foram concretas. Nesse sentido, Abramo (1999) aponta que:

[...] o salário mínimo era na época [1975] absolutamente insuficiente para garantir a finalidade para a qual havia sido criado 30 anos antes, ou seja, adquirir a cesta básica. Isso se evidencia no fato de que todos aqueles que recebiam um salário mínimo tinham que trabalhar mais que o dobro da jornada legal (15 horas e 55 minutos diários, durante 30 dias por mês) para cobrir os gastos básicos de sua família com nutrição, moradia, transporte e vestuário. [...] Vale assinalar que a diminuição do poder de compra do salário mínimo se acentua nos anos do "Milagre" Econômico. Em razão dessa diminuição, quem recebesse um salário mínimo teria que trabalhar, em 1973, um total de 147 horas e 4 minutos, e em 1974, um total de 163 horas e 32 minutos para adquirir apenas a ração essencial mínima. Em 1959, essa mesma quantidade de gêneros alimentícios correspondia a 65 horas e 5 minutos de trabalho para quem ganhasse um salário mínimo. (ABRAMO, 1999, p. 54).

Vale ressaltar que os salários dos metalúrgicos do $\mathrm{ABC}$, especialmente os de São Bernardo, eram os maiores dentre os dos trabalhadores da indústria no Brasil. O que não significa, conforme procuram mostrar Antunes (1992) e Maroni (1982), que houvesse uma "aristocracia operária", ou mesmo, como comenta Abramo (1999), que os operários estivessem satisfeitos com as condições de trabalho ou seus salários. Além de não acompanhar o aumento do custo de vida, os salários não acompanhavam os índices de crescimento da indústria. E ainda, apesar de políticas de reajustes salariais serem definidas pelo governo durante o regime militar, as empresas também contribuíam para a diminuição do valor real dos salários por meio de mecanismos que estabeleciam cargos, funções, carreiras, faixas salariais, critérios de promoção etc.

Importante destacar que, embora a indústria tenha proporcionado um crescimento no número de postos de trabalho conforme aumentava sua produção, a instabilidade e a insegurança assolavam a vida dos operários. A rotatividade era adotada como medida para "se livrar" dos operários indesejáveis, ou seja, daqueles que não interessavam à empresa, ou pela improdutividade, ou por serem militantes ou membros de sindicato. As empresas chegavam a induzir a rotatividade de mão-de-obra como forma de controle sobre os trabalhadores, realizando muitas vezes demissões arbitrárias.

Além da insegurança quanto à estabilidade no emprego, os trabalhadores tinham que enfrentar outra situação geradora de muito sofrimento: a intensificação do ritmo de trabalho. 
Tal intensificação não correspondia exatamente ao clássico ritmo da esteira que aumenta a produtividade, mas sim à jornada de trabalho que era frequentemente estendida. Como critério de contratação as empresas, mesmo não oficialmente, usavam a aceitação do operário em cumprir quantas horas extras fossem necessárias e solicitadas. As empresas não somente exerciam grande pressão para o cumprimento das horas extras, mas também conseguiam maneiras de burlar a legislação no sentido de não acrescer essas horas na contagem das bonificações. Muitos trabalhadores, por sua vez, solicitavam às empresas para que fizessem horas extras, pois era um complemento no salário importante para seu sustento. As excessivas horas a mais, na jornada de trabalho, resultavam em grandes riscos de saúde e segurança. Os acidentes de trabalho aumentavam drasticamente, assim como as doenças, muitas vezes crônicas, resultantes de grande esforço físico e mental. As condições materiais dentro das fábricas tampouco ajudavam a prevenir os acidentes. Segundo Abramo (1999), “[...] em 1974 e 1976 o Brasil conquistou o título de campeão mundial de acidentes de trabalho.” (p. 117).

A organização do trabalho de pressupostos tayloristas, chamada também de "administração científica", teve peso relevante para o processo de eclosão das greves. Weil (1996), que se voluntariou a trabalhar como operária na França, na década de 1930, aponta para o quanto a desvalorização salarial é uma consequência da inferioridade e da servidão, que são relegadas aos trabalhadores que vendem sua força de trabalho. A divisão e a desqualificação da classe operária estariam na base do método taylorista, o qual encara cada trabalhador individualmente e estimula a concorrência entre eles, em busca de gratificação. Diz a autora:

No espírito de Taylor, assim como no dos industriais aos quais ele ia comunicando regularmente os resultados de seus estudos, a primeira vantagem da nova organização devia ser a de romper com a influência dos sindicatos. Desde seu nascimento, a racionalização foi antes, essencialmente, um método para se fazer trabalhar, mais do que um método para trabalhar melhor. (WEIL, 1996, p. 146).

Nesta linha, Maroni (1982) apresenta esta questão como decisiva em relação ao trabalho dos metalúrgicos do $\mathrm{ABC}$ na década de 70, e a consequente greve em 1978. A organização do trabalho passa pelos níveis superiores da hierarquia, cabendo ao operário apenas conhecer e realizar a sua função específica dentro da linha de montagem. $\mathrm{O}$ trabalho individual é valorizado, em detrimento da coletividade. O planejamento se dá em postos 
individuais de trabalho e as bonificações salariais estão relacionadas a desempenhos individuais. Neste sistema, o trabalho é pensado por aqueles que administram e é executado por aqueles que vendem sua força de trabalho, criando-se assim a necessidade de um supervisor, o qual inspeciona a qualidade da produção e, muitas vezes, o rendimento; ou seja, se o operário produz a quantidade máxima no menor intervalo de tempo.

Maroni (1982) cita ainda as formas mais comuns, à época, de suprimir a resistência dos trabalhadores frente à organização de trabalho taylorista. Ela aponta para a preocupação de algumas empresas em primeiro dominar, desqualificar e desorganizar a mão-de-obra, para depois pensar na produtividade.

Valendo-se de pensamentos de Michel Foucault, Maroni (1982) discute a organização do trabalho fabril em termos de "poder disciplinar". Tal organização vem a serviço da dominação por meio do controle total do tempo e do espaço. O espaço da fábrica é milimetricamente projetado não somente para a eficácia da produção, mas principalmente para o controle e a vigilância sobre os operários. O tempo também é controlado, para que o operário não tenha possibilidade de desviar sua atenção de sua função específica dentro do processo de produção - sendo que manter a atenção em sua função específica significa não ter tempo de apreender o processo de produção em sua totalidade. O controle do tempo e do espaço, de acordo com Maroni (1982), torna possível “o exercício de vigilância, o rompimento de comunicações perigosas e a criação de um espaço útil aos interesses do capital." (p. 29).

Os trabalhadores metalúrgicos não deixaram de se manifestar diante destas condições, a resistência dentro das fábricas ocorria de diversas formas. Não necessariamente levava a grandes movimentos, não favorecia diretamente organizações coletivas, porém simbolicamente exercia um papel de não deixar com que a repressão aniquilasse de vez a possibilidade de luta contra a exploração sofrida pelos operários.

Como formas de se rebelar contra os abusos das chefias, conforme Abramo (1999), os operários realizavam brincadeiras e "loucuras", como eles mesmos denominavam, as quais consistiam em desde atirar bolas de pano embebidas em óleo, até atear fogo na capa dos superiores. Essas ações serviam como válvulas de escape à repressão e ao poder disciplinar. A autora chama a atenção para o termo "loucura" como uma recusa da normalidade repressiva das relações de trabalho. Sobre esses atos, diz a autora: “[...] revelam-se aqui, por meio do poder subversivo do riso, as inesperadas formas de afirmação e recuperação da subjetividade violentada e humilhada no cotidiano do trabalho." (Ibid., p. 115). 
O próprio processo de produção não escapava. Frederico (1979) faz referência às formas de sabotar e atrasar a produção, tais como: mudar a rotação das máquinas, desgastar ferramentas, empilhar mal as peças, entre outros atos. O atraso na produção (chamado de "operação tartaruga", "marcha lenta" etc.) é considerado pelo autor "um passo decisivo para a frente: o operário sai do círculo estreito de sua revolta 'pessoal' contra os chefes e do vandalismo sobre as máquinas, e se lança numa ação cujo limite é a própria greve." (FREDERICO, 1979, p. 85).

Paralelamente a estas ações isoladas dentro das fábricas, o Sindicato dos Metalúrgicos de São Bernardo e Diadema desenvolvia uma linha de ação importante para a eclosão das greves em 1978. Após sofrer intervenção do regime militar em 1964 (como todos os sindicatos do país), o Sindicato se afinou com o discurso oficial do governo em prol do progresso e desenvolvimento do país. Abramo (1999) desenha na linha do tempo, durante a década de 1970, a ação deste Sindicato e como este foi se aproveitando de brechas para uma substancial mudança em seu discurso. A autora mostra as mudanças de discurso por meio de trechos colhidos da Tribuna Metalúrgica, boletim publicado pelo Sindicato.

Nos primeiros números da Tribuna Metalúrgica, encontrava-se um alinhamento com o discurso do Brasil Grande, em plena época do "milagre econômico". O discurso era de colaboração com o desenvolvimento econômico do país, apontando para o importante papel que o setor metalúrgico desempenhava neste sentido.

Aproveitando-se deste canal, a linha editorial da publicação passa a buscar e exigir reconhecimento do trabalho desempenhado pelos metalúrgicos. A reivindicação de uma vida digna, portanto, de salários que tornem a vida digna, passa em meados de 1971 e 1972 a estar cada vez mais presente. A Tribuna passa, então, a apontar que as margens de lucro das empresas aumentam a cada ano e que melhores salários podem ser reivindicados a partir daí. A distinção entre os "ricos" e os "pobres" começa a ser feita como recurso de linguagem e retórica. Posteriormente, por volta de 1974, surgem as terminologias relativas à classe, opondo-se ao patronato. Os abusos de chefias e patrões passam então a ser denunciados; e o tom dos textos passa a fazer apelo à união da classe, mostrando a importância da sindicalização.

Também os movimentos da Igreja Católica, na década de 1970, tiveram grande influência na reorganização sindical. Isto porque a igreja assume um papel e um discurso de combate à pobreza e defesa dos direitos humanos. Sua aproximação aos bairros pobres tornou inevitável seu contato com as condições de vida dos operários. 
Um relevante estudo sobre as relações da Igreja Católica e o movimento operário no ABC Paulista, foi realizado por Martins (1994). Mesmo que este estudo focalize um período que vai até 1975 , a autora comenta que:

O trabalho de organização dos trabalhadores, que vai aparecer nas greves de 1978 e 1980, que atingiram vários setores da classe trabalhadora, foi um longo processo do qual participaram diferentes grupos políticos e, também, grupos de militantes dos movimentos católicos. (MARTINS, 1994, p. 235).

Martins (1994) ainda aponta que:

Diversos depoimentos ressaltam a importância da atuação dos militantes católicos na retomada dos caminhos da luta da classe trabalhadora nos anos difíceis da década de 70. Com a sua incansável resistência, através de um trabalho árduo e miúdo, esses militantes foram rearticulando os operários no interior da fábrica, aliando-se a outros grupos de oposição. (p. 232).

Este trabalho "árduo e miúdo", na década de 1970, estava diretamente ligado às ações dos movimentos Juventude Operária Católica (JOC) e Ação Católica Operária (ACO). Por meio de práticas democráticas, antiautoritárias e de valorização do povo, a Igreja Católica buscava imprimir uma ação libertadora, não mais assistencialista como comumente realizava frente a condições de pobreza e miséria da população. A Assembleia de Medellín, que reuniu representantes da Igreja Católica da América Latina em 1968, teve por foco a luta "pelos pobres, pela libertação integral e pelas comunidades de base." (MARTINS, 1994, p. 223). A Teologia da Libertação também teve papel fundamental neste processo enquanto princípio para ação da igreja.

Sader (1988), em seu trabalho sobre os movimentos sociais na década de 1970, ao identificar "as agências produtoras de discurso", detecta, além do novo sindicalismo e dos movimentos de esquerda, a Igreja Católica tendo importante papel, principalmente, por meio das Comunidades Eclesiais de Base. 


\title{
1.2 As greves
}

Em 12 de maio de 1978 teve início o ciclo grevista que marcaria a retomada do movimento sindical, com toda sua força, depois da intervenção do governo militar nos Sindicatos, em 1964, após o golpe.

$\mathrm{Na}$ fábrica da Scania, a greve teve seu início em uma ação espontânea dos trabalhadores, conforme aponta o militante sindical Gilson Menezes em seu depoimento (A GREVE..., 1979):

\begin{abstract}
A greve nasceu de uma decisão espontânea do pessoal do diurno da ferramentaria. $\mathrm{O}$ pessoal do noturno estava saindo, quando ninguém do dia entrou e não ligou as máquinas. Ninguém começou a trabalhar. Não se ouvia o menor barulho na fábrica. [...] Tudo mundo marcou o cartão, mas ninguém trabalhou. Das sete até às oito horas, nós ficamos de braços cruzados do lado da máquina sem fazer nada. (p. 7).
\end{abstract}

A insatisfação dos trabalhadores era em relação aos salários. A empresa encontrava diversas maneiras de descontar qualquer centavo na folha de pagamento, e ainda não dava o reajuste esperado pelos trabalhadores. Chegou-se então a uma situação limite, onde os trabalhadores não podiam mais suportar sem dar uma resposta. A reação inicial dentro da Scania foi a paralisação. Segundo o depoimento de Gilson Menezes, “[...] a palavra greve estava difícil de sair. Então o pessoal propôs parar dentro da fábrica. Parar, mas não era greve. Era uma parada." (BARGAS; RAINHO, 1983, p. 67). Esta ação ocorreu dentro da Scania, onde os operários espalharam a proposta, no "boca a boca", de paralisação para o dia 12 de maio. O Sindicato dos Metalúrgicos de São Bernardo e Diadema não participou desta decisão, que foi tomada na fábrica.

De qualquer maneira, o Sindicato foi chamado para realizar as negociações. Ao mesmo tempo, a greve espalhou-se pelas indústrias metalúrgicas de São Bernardo, e aos poucos a "onda" grevista chegou a outras cidades do ABC, bem como a São Paulo, a Osasco e outras cidades do Estado. Cada conjunto de trabalhadores em cada fábrica tinha sua própria forma de fazer greve: parciais e/ou setoriais, como na Volkswagen; totais e prolongadas, como na Ford; e paralisações relâmpagos, como na Gemmer e na Cima. Era a eclosão de um movimento que englobou cerca de 150 mil trabalhadores do ramo metalúrgico e, apesar de 
atingir uma imensa proporção deste operariado, foi uma greve por fábricas. Afinal, era um recomeço, não surgiu "do nada", pois como vimos, a resistência operária se deu de diversas formas, inclusive por meio de tímidas movimentações grevistas durante a década de 1970. Porém foi neste momento, de forma espontânea e sem previsibilidade da proporção que o movimento atingiria, que se deu o ressurgimento de movimentos de trabalhadores fora da sombra do regime militar.

A greve de 1978 resultou em acordo coletivo, feito pelo Sindicato com as empresas. O acordo previa reajuste de 39\% para a categoria. Durante o segundo semestre de 1978, algumas greves aconteceram em algumas empresas, com o intuito de cobrar o cumprimento dos acordos. Por outro lado, muitas demissões foram realizadas, além de haver certa precaução por parte das empresas, que com intermédio da FIESP publicou uma circular que sugeria não pagamento das horas de paralisação e fechamento das fábricas em caso de greve.

Em 1979 depois do fechamento da fábrica Resil, durante uma greve em dezembro de 1978, experienciava-se uma nova forma de greve por meio dos piquetes. As ações do Sindicato dos Metalúrgicos de São Bernardo e Diadema intensificavam-se com a aproximação das bases da ação e do cotidiano sindical.

No início de 1979 o Sindicato de São Bernardo elaborava sua pauta de reivindicações, onde estava presente pontos relativos a reajuste salarial (relativo às perdas históricas no valor real dos salários), estabilidade para delegados sindicais, diminuição das jornadas de trabalho, entre outros. Importante ressaltar a divergência do Sindicato de São Bernardo com a Federação dos Metalúrgicos de São Paulo, que representava os trabalhadores da capital. Este último, "expressão clássica da burocracia sindical atrelada e subserviente ao estado" (ANTUNES, 1992, p. 43, nota de rodapé), procurou firmar acordos com o empresariado, enquanto o primeiro não chegou a um acordo satisfatório, o que inevitavelmente culminou em greve.

O Sindicato começou então a organizar as assembleias, com a presença de milhares de pessoas. Não foi o Sindicato que decretou a greve de 1979, mas sim uma assembleia. A greve neste momento, diferentemente de 1978, não era por fábrica, mas sim de massa.

Mesmo não sendo uma greve decretada pelo Sindicato, seu papel foi de extrema importância especialmente por parte do presidente do Sindicato, Lula. Os trabalhadores de sua categoria se sentiam seguros com sua presença na direção do movimento grevista, chegava a ser quase uma dependência. Fato que pode ser percebido na situação em que Lula se ausentou 
durante um curto período de três dias da direção do movimento, e ninguém conseguiu conduzir a assembleia que ocorreu.

Antes mesmo de sua ausência, Lula viu o Sindicato sofrer intervenção por parte do Estado, momento em que a Igreja da Matriz passou a ser o novo local de concentração. Assim, o movimento grevista recebeu apoio da Pastoral Operária do ABC, dirigida por D. Cláudio Hummes. Foi nessa ocasião que Lula se ausentou, e teve sua volta quase que exigida pelo movimento grevista.

Entretanto, ao voltar, o movimento já estava sofrendo um "refluxo", conforme aponta Ricardo Antunes (1992), uma vez que dias depois foi decidido em assembleia a volta ao trabalho. Seria uma volta provisória, isto é, se em 45 dias a FIESP não chegasse a um acordo com o Sindicato, a greve seria decretada novamente. Logo após a volta ao trabalho, as empresas não cumpriram o acordo que haviam feito de não demissão: houve demissão em massa. Os 45 dias de espera por um acordo foram acirrados e tensos. Alguns trabalhadores paralisaram novamente o trabalho e a produção assim que souberam das demissões e do desconto salarial pelos dias não trabalhados. No dia previsto para voltar à greve, chegou-se a um acordo entre a FIESP e o Sindicato. Mesmo não sendo o que os trabalhadores desejavam, o Sindicato avaliou como sendo a melhor saída, pois haveria grandes possibilidades de enfraquecimento de um novo movimento grevista naquele momento.

Ao fazer a análise da greve geral de 1979, Antunes (1992) a considera vitoriosa por ter gerado grande impulso a movimentos reivindicatórios por parte de trabalhadores assalariados em todo o país. Alguns fatores também podem apontar a greve como vitoriosa, tais como: o avanço político por parte do Sindicato, que conseguiu realizar um trabalho de base importante dando sequência e organizando uma greve de início espontâneo; o fato de o movimento ter conseguido afundar um projeto que visava desestruturar a retomada do movimento sindical; a possibilidade de organização do movimento com o Sindicato sob intervenção do Estado; e a própria retomada do Sindicato.

Entretanto, a avaliação geral dos trabalhadores, por não terem conseguido os reajustes salariais reivindicados, foi de uma greve derrotada. Esta análise, do ponto de vista de Antunes (1992), foi equivocada e pode ter acarretado graves consequências ao movimento grevista em 1980.

Mais uma vez nenhuma proposta dos empresários foi capaz de encontrar aceitação por parte do Sindicato e da base metalúrgica, uma vez que o Sindicato tinha como princípio lutar por um reajuste que estivesse à altura de suas expectativas. Outras reivindicações estariam na 
pauta, mas tendo em vista o sentimento de derrota da classe ao final da greve de 1979, devido ao reajuste abaixo das expectativas, a luta pelo salário seria prioridade.

Após dois anos seguidos de greve, tanto o governo e as empresas quanto o Sindicato e a organização do movimento estavam atentos às possíveis mexidas nas peças do xadrez. A repressão estava de prontidão para cortar pela raiz o movimento grevista. Este estava organizado de maneira que não fosse apanhado de surpresa pelas ações repressivas - a diretoria do Sindicato, liderada por Lula, estava à frente na organização da greve -, se houvesse alguma baixa, um comando de greve estaria pronto para assumir a direção do movimento. Cada diretor do Sindicato que fosse preso ou não tivesse condições de seguir à frente seria substituído por alguém do comando. E ainda havia uma comissão de salários e mobilização, que também estaria de prontidão para assumir uma posição na organização da greve. Esta comissão também ficou responsável por fazer a ponte entre o comando de greve e as bases nos bairros.

Após a deflagração da greve e a paralisação do trabalho por parte de $90 \%$ dos trabalhadores da categoria em São Bernardo, a repressão começou a agir. O Tribunal Regional do Trabalho (TRT), que primeiro havia se considerado incompetente para a apreciação da legalidade da greve, reconsiderou sua decisão e declarou sua ilegalidade. A intervenção no Sindicato foi realizada e os líderes foram presos, dentre eles Lula. O embate era constante.

A principal tática do aparelho repressor, quando implantada, foi o fator determinante para o enfraquecimento do movimento, pois houve o impedimento da realização de assembleias. O Estádio da Vila Euclides e as praças públicas estavam bloqueados para qualquer tipo de manifestação, por meio da ação violenta da polícia. E, ao mesmo tempo, o empresariado se negava a negociar. O movimento foi enfraquecendo. O Sindicato, no entanto, por meio de declarações de seus representantes, ou por boletins da greve, manifestava iminente vitória, o que não correspondia à realidade. Os metalúrgicos aos poucos voltaram ao trabalho, e as palavras de ordem tentavam mostrar que o movimento ia bem, com força. Novamente, Antunes (1992) considera equivocada a análise feita pela direção sindical em relação à greve. 


\section{O ESTUDO DA MEMÓRIA EM PSICOLOGIA SOCIAL}

As greves dos metalúrgicos da região do $\mathrm{ABC}$ Paulista são eventos marcantes na história do Brasil. Elas estão inseridas em um contexto de reabertura política, na transição do regime militar ditatorial para um regime democrático. Para os movimentos trabalhistas, as greves têm ligação direta com a fundação do Partido dos Trabalhadores (PT) e da Central Única dos Trabalhadores (CUT). As formas de atuação do Sindicato dos Metalúrgicos de São Bernardo e Diadema são modelo para a instituição do chamado Novo Sindicalismo, na década de 80 .

As histórias das greves dão muito o que pensar. Principalmente se nos voltarmos para o ponto de vista do trabalhador.

O estudo de Antunes (1992) sobre as greves dos metalúrgicos do ABC contém narrativas interessantes sobre os processos das greves, e se direciona para uma análise dos avanços e retrocessos possíveis da consciência do operariado sobre sua condição de classe no contexto capitalista.

Maroni (1982) foca seu estudo nas relações de poder dentro das fábricas, e como a insuportável pressão sobre os trabalhadores, em uma organização de trabalho taylorista, levou-os a organizar a greve de 1978. As comissões de fábrica tiveram importante papel neste processo, uma vez que foi a organização dos trabalhadores, que aconteceu de forma horizontal, o fator primordial para a resistência à organização impositiva e vertical da organização de trabalho.

Abramo (1999) sugere que os significados da greve de 1978 para os trabalhadores estão intimamente ligados ao resgate de sua dignidade. "A greve é que permite ao trabalhador, em última instância, sentir-se novamente um ser humano.” (p. 269). A força do trabalhador em sua própria individualidade e de seu poder coletivo é revelada no processo de greve.

Estes estudos, dentre outros, sobre as greves dos metalúrgicos do $\mathrm{ABC}$, abordam aspectos que interessam ao campo da psicologia social. Mais especificamente, a uma psicologia social atenta ao homem em companhia de seus pares; ao homem agindo de acordo com as convenções sociais e ao mesmo tempo com o que tem de singular. 
O exame de processos psíquicos beneficia-se do recurso ao seu tempo social, um recurso à maneira pela qual cada época geralmente organizou as relações dos homens com outros homens, com a cidade e também com a natureza. Esta disciplina de fronteira, a Psicologia Social, caracteriza-se não pela consideração do individuo, pela focalização da subjetividade no homem separado, mas pela exigência de encontrar o homem na cidade, o homem no meio dos homens, a subjetividade como aparição singular, vertical, no campo intersubjetivo e horizontal das experiências. (GOLÇALVES FILHO, 1998, p. 14).

Um trabalhador metalúrgico convive com seus colegas na fábrica, com seus companheiros na igreja, com seus representantes no Sindicato e passa pela experiência de greve, uma experiência coletiva. Na massa de grevistas seria possível, se houvesse tempo e disponibilidade, destacar cada trabalhador, que tem sua história de vida digna do interesse do pesquisador.

Em psicologia social pode-se recorrer a depoimentos para estudo de determinados fenômenos. Os relatos dos trabalhadores grevistas podem enriquecer a compreensão da participação e adesão destas pessoas às greves. É importante uma escuta atenta e dedicada por parte do pesquisador. Ecléa Bosi (2003) alerta que: "Da qualidade do vínculo vai depender a qualidade da entrevista. Se não fosse assim, a entrevista teria algo semelhante ao fenômeno da mais-valia, uma apropriação indébita do tempo e do fôlego do outro.” (p. 60-61).

A abordagem para a pesquisa deve ser, portanto, qualitativa. Um levantamento estatístico não seria adequado para entendermos a esfera psicossocial de um fenômeno como a greve.

Ainda, no caso das greves dos metalúrgicos do $\mathrm{ABC}$, que ocorreram no fim dos anos 70 e nos anos 80 e que possuem seu lugar social, cultural e histórico, deve-se buscar nos depoimentos que privilegiem a memória destes acontecimentos um recorte psicossocial. É no importante trabalho de Bosi (1994), sobre memória social a partir das lembranças de velhos, que teremos a sustentação teórica para este estudo.

Henri Bergson é um dos autores de referência para Bosi pensar a memória. Ele aponta para a íntima relação entre percepção e memória. Nesse sentido, a percepção do presente em um estado puro seria mais um conceito que uma constatação real, já que a memória carrega uma função de conservação dos estados psíquicos já vividos; e a percepção do presente é necessariamente carregada de lembranças. Então, a memória permite não apenas a relação do corpo presente com o passado, mas também tem interferência decisiva nas representações 
atuais. "A memória teria uma função prática de limitar a indeterminação (do pensamento e da ação) e de levar o sujeito a reproduzir formas de comportamento que já deram certo." (BOSI, 1994, p. 47).

Outro autor de referência para o estudo da memória de velhos para Bosi é Maurice Halbwachs, sociólogo durkheimiano, que entendia a memória como fenômeno social. Para Halbwachs, “[...] uma semente de rememoração pode permanecer um dado abstrato, pode, ainda, formar-se em imagem e como tal permanecer, ou, finalmente, pode tornar-se lembrança viva. Estes destinos dependem da ausência ou presença de outros que se constituem como grupos de referência." (MAHFOUD; SCHMIDT, 1993, p. 288). Este grupo de referência é aquele ao qual o sujeito pertence de forma enraizada. A memória do sujeito é construída no grupo e muitas vezes evocada em grupo, apesar de ser o sujeito quem lembra. A memória individual pode ser então entendida como uma forma singular de confluir e articular as influências sociais nas lembranças do sujeito. A memória coletiva é o trabalho de um grupo em articular as lembranças de seus indivíduos, localizando-as em "quadros sociais" (Ibid.).

A ideia de memória como um reviver, portanto, não cabe ao pensamento de Halbwachs, que a encara como ato de reconstrução, pois, dentro de um contexto atual de interesses, as vivências do passado são resgatadas e localizadas no tempo, no espaço e no conjunto de relações sociais.

É na memória coletiva que as tradições dos grupos encontram sua força. As imagens, lendas e crenças antigas se atualizam e são re-significadas a cada momento de lembrança. Mas a força coletiva sobre a memória a leva ao risco de "ideologização". A interpretação do grupo sobre um fato significativo do passado, muitas vezes, supera o caráter testemunhal do sujeito que, mesmo participante da sua história, privilegia a versão imposta pelo grupo sobre o acontecimento.

$\mathrm{Na}$ análise de sua pesquisa, Ecléa Bosi (1994) discorre sobre dois temas bastante presentes nos depoimentos de seus entrevistados: a memória política e a memória do trabalho.

Sobre a primeira, Bosi alerta, em relação às lembranças de militantes, para o risco de estereotipia, caindo em um discurso ideológico majoritário em seu grupo político. Mostra também, as formas como o entrevistado "vai misturando na sua narrativa memorialista a marcação pessoal dos fatos com a estilização das pessoas e situações, e, aqui e ali, a crítica da própria ideologia.” (BOSI, 1994, p. 459). Esta mistura é decorrência de como se imprime uma marca pessoal nas lembranças que são fruto de testemunho de fatos coletivos: familiares, sociais e políticos. Muito embora uma memória coletiva se construa por laços sociais, é o 
indivíduo que lembra e, na sua história de vida, encontra significados para os acontecimentos que ficaram em sua memória. As histórias de vida imprimem marcas na participação política, ou ainda, a participação política está imbricada na história de vida de um militante.

Sobre a memória do trabalho, Bosi (1994) afirma o quanto os entrevistados, principalmente os que já não trabalham, trazem um laço afetivo muito forte ao ofício em seus detalhes e segredos, quando o fazer passa a ser o próprio lembrar. A autora demonstra que o trabalho envolve "os movimentos do corpo penetrando fundamente a vida psicológica" (p. 471), e ao mesmo tempo é meio de inserção nas relações sociais. Pensando na condição operária, como Simone Weil descreve, ficam as perguntas: Quais são as memórias de um trabalho na fábrica na linha de montagem? Há o que narrar sobre o trabalho repetitivo? Que aspectos do trabalho poderiam ter levado o trabalhador a entrar em greve?

A memória, segundo Bosi (2003), é "um trabalho sobre o tempo, mas sobre o tempo vivido, conotado pela cultura e pelo indivíduo.” (p. 53). O tempo mercadológico, no entanto, é aquele que culmina no desenraizamento. Weil (1996) afirma que "o ser humano tem uma raiz por sua participação real, ativa e natural na existência de uma coletividade que conserva vivos certos tesouros do passado e certos pressentimentos do futuro.” (p. 411). Esta raiz é cortada no tempo mercantil, na opressão alienante e, consequentemente, no trabalho operário, alijado de qualquer pensamento e reflexão na linha de montagem e fora dela, dada a fadiga e o adoecimento resultantes. A memória como enraizadora de grupos ou coletividades talvez encontre forças na militância dos trabalhadores.

Em um estudo sobre a militância estudantil no Instituto de Psicologia da Universidade de São Paulo, Mortada (2002) afirma:

A militância estudantil, sem dúvida, é um fenômeno que deita raízes no passado, beneficiado pelo recurso a outros tempos. Mas é também no militante, em seu percurso singular dentro do movimento estudantil, que a militância se revela, aparece como experiência enriquecedora ou esvaziadora, ativista ou não. Para refletirmos acerca da experiência política no movimento estudantil, de seus impasses e das angústias que provoca, não podemos dispensar o recurso à memória de seus agentes. Um outro tempo, evocado por aqueles que o atravessaram, pode assumir uma realidade e uma vitalidade que não encontramos em arquivos mortos ou registros inertes. (p. 4-5). 
Nesta linha, podemos sugerir a importância do recurso à memória para o estudo da participação dos operários nas greves. Cada um deles trará uma história única, com seus caminhos percorridos de acordo com sua experiência. Por meio da narrativa, o depoente resgata o tempo vivido. Resgata a experiência do trabalho, da exploração de classes, e da militância enquanto forma de resistência a esta exploração. A memória de um homem pertencente a uma coletividade, participante de um movimento coletivo como a greve, evoca a experiência singular ante a um acontecimento político. A participação em greves, que ocorreram em um momento de retomada da organização sindical e reivindicatória dos operários, tem repercussões não apenas sociais, mas também psicológicas, na subjetividade dos trabalhadores. 


\section{OBJETIVOS: AS PERGUNTAS QUE GUIAM A PESQUISA}

O foco nesta pesquisa incide nas lembranças da vivência concreta de um indivíduo enquanto metalúrgico do $\mathrm{ABC}$ que trabalhou na fábrica, que sofreu as duras condições de trabalho e que fez greve. Memória de uma pessoa que viveu e agiu em companhia de outras: seus companheiros de trabalho, de Sindicato e de bairro, sua família; e em oposição a outras: patrões, governo, imprensa. Memória, como vimos antes, que é do indivíduo, mas que tem em sua construção uma participação coletiva.

Buscaremos, a partir de então, saber o que motivou os trabalhadores entrevistados a aderir à greve. As motivações foram apenas salariais? Qual foi a influência de seus companheiros neste processo? Como foi para o trabalhador a decisão de entrar em greve?

As lembranças da fábrica, do ofício, do salário, das condições de trabalho, da higiene e da segurança no ambiente fabril, e ainda das relações entre os colegas e destes com os patrões, podem dar pistas sobre as motivações que levaram o trabalhador metalúrgico a entrar em greve. Estas pistas aparecerão em narrativas de episódios ocorridos na fábrica. $\mathrm{O}$ despotismo patronal, por exemplo, se mostrará por meio de alguma história que o metalúrgico tenha para contar, talvez a de como foi obrigado a fazer hora extra sob ameaça de demissão. Ou então, contará a história de um acidente de trabalho que presenciou ou mesmo sofreu.

As duras condições de trabalho podem ter levado o trabalhador a refletir sobre a exploração e a repressão política. Mas será que somente estas experiências de trabalho na fábrica seriam suficientes para se revoltar contra as condições vivenciadas? A memória política entra com importância neste contexto. Provavelmente as conversas com companheiros, a adesão a grupos de bairro ou da Igreja Católica, a vivência de protestos silenciosos, como as operações de retardamento de produção, foram momentos importantes para que o trabalhador pudesse tomar consciência da opressão sofrida. Esta tomada de consciência pode aparecer na narrativa do depoente, implícita ou explicitamente, por meio do percurso de sua participação nos movimentos operários ou sindicais, e no processo que levou à realização das greves.

Deve-se, ao analisar a memória política, prestar atenção a possíveis idealizações ou estereotipias que, geralmente, estão atreladas a interpretações que o grupo de referência dá aos fatos. Na narrativa de sua trajetória política, que culmina em uma greve, o trabalhador pode 
entrelaçar suas vivências de caráter testemunhal com as versões construídas coletivamente para o fato.

A greve é uma forma de resistência e luta frente às condições do operariado. Mas não apenas, pois se trata de um momento de quebra da rotina de trabalho, a temporalidade das ações se transforma e toma outros significados que podem ser diversos. Weil (1996), sobre uma greve de metalúrgicos da qual participou como trabalhadora, escreve:

Como a gente se sente entre colegas nessas oficinas em que, quando eu estava lá, cada um se sentia tão só, atrás de sua máquina! Alegria de ouvir, em vez de barulhos impiedosos das máquinas, símbolo tão patente da necessidade dura que nos dobrava, música, cantos, risos. (p. 127).

A memória das greves caracteriza-se como a memória de um momento de ruptura do cotidiano, quando o trabalhador pode refletir sobre este e agir com propósito de sua mudança. Interessa-nos que o depoente conte sobre este momento e qual foi sua implicação nele. Teria o trabalhador aderido imediatamente à greve? Como ele sentiu a interrupção do trabalho? Perguntas como estas serão respondidas com a narração deste momento de irrupção da greve, contada sob o ponto de vista de alguém inserido nos acontecimentos.

Considerando ainda que a memória parte de interesses e preocupações atuais em direção ao passado (é reconstrução do passado, não revivência), deve-se buscar a identificação desta trajetória. As greves no $\mathrm{ABC}$ tiveram consequências e repercussões que moldaram a sociedade e a política de hoje. O atual presidente da República, Luís Inácio Lula da Silva, foi a principal liderança das greves. Foi eleito pelo partido que teve um dos ramos de suas origens no sindicalismo do $\mathrm{ABC}$. Como se daria este entrelaçamento na memória? As perguntas que serão feitas aos entrevistados referem-se às lembranças de fatos ocorridos na década de 1970, mas provavelmente não escaparão as idas e vindas do presente para o passado e do passado para o presente.

Esta pesquisa pretende também investigar como os trabalhadores significam sua experiência de participação em greves. Mais especificamente, quais são as lembranças dos trabalhadores sobre as pessoas, os grupos e os sindicatos na ação grevista; o entrelaçamento das lembranças pessoais, de caráter testemunhal, com as versões e interpretações coletivas; como os fatos narrados relacionam passado e presente. Em outras palavras, o que permanece de importante e significativo dessas greves para o trabalhador? A organização coletiva teria deixado marcas na maneira de se relacionar com o mundo e as pessoas? A luta pelos direitos 
guia o trabalhador até hoje no campo da política? Tentaremos responder juntos, pesquisador e depoentes, a estas perguntas. 


\section{MÉTODO}

\subsection{Entrevista semidirigida}

A coleta de dados foi feita com base em uma abordagem qualitativa, por meio de entrevistas individuais semidirigidas. Estas procuram criar condições para uma narrativa pessoal da experiência vivida, ao mesmo tempo em que estimulam a comunicação do entrevistado com o conteúdo que procuramos pesquisar (GONÇALVES FILHO, mimeo) ${ }^{1}$.

Foi elaborado um roteiro de entrevista que buscou estimular o depoente a realizar um trabalho de memória expresso pela narrativa, já que o trabalho da memória, realizado pelo depoente, deve ser estimulado pelas questões do roteiro. Estas questões não pressupõem respostas certas ou erradas,.tampouco devem fazer o entrevistado buscar o que, supostamente, o entrevistador espera. O depoente deve sentir-se livre para narrar, para contar sua experiência, a seu modo. Muitas vezes as marcações da memória não seguem o tempo cronológico, mas uma lógica dotada de um significado próprio, significado este encontrado na vida do depoente.

Não se trata, no caso desta pesquisa, de trabalhar com histórias de vida. Sendo assim, o roteiro se presta a manter o foco das narrativas em um tema específico. Nesse sentido, as narrativas sobre as greves dos metalúrgicos do $\mathrm{ABC}$, bem como seus antecedentes e desdobramentos, devem ser suscitadas pelas perguntas do roteiro. No entanto, o respeito à temporalidade singular da narrativa de cada depoente se mantém. As perguntas demandam trabalho por parte do depoente.

Procurou-se criar condições para a narrativa pessoal, ao mesmo tempo provocando relacionamento do depoente com a experiência que, em comum, pretendemos todos interrogar e pensar (GONÇALVES FILHO, mimeo). Como afirma Gonçalves Filho (2003), "o que chamamos de 'coleta de dados' pressupõe proximidade entre nós e quem vai ser entrevistado, fora de qualquer recurso nosso a expedientes de superioridade.” (p. 207).

\footnotetext{
${ }^{1}$ Texto usado na disciplina Psicologia Social I (graduação IP-USP).
} 
É importante destacar que os dados da pesquisa basearam-se em depoimentos e foram gravados em fita cassete com autorização dos depoentes, que posteriormente foram transcritos por mim, o pesquisador.

\subsection{Análise das entrevistas}

Sobre a análise de depoimentos, que deverá ser qualitativa, afirma Gonçalves Filho (2003) que esta implica na "comunicação de uma perspectiva (do depoente) com as demais" (p. 211), pois o trabalho é de autoria de ambos, pesquisador e depoente. A interpretação se dá pelo diálogo entre as teorias e os depoimentos, sem sobreposição de um sobre outro, diálogo “convergente, complementar e divergente." (p. 213).

\subsection{Os depoentes}

Inicialmente, estabeleceu-se como primeiro critério de escolha dos depoentes que estes tivessem trabalhado como metalúrgicos em alguma empresa localizada na região do Grande $\mathrm{ABC}^{2}$, no período em que aconteceram as greves (a partir de 1978).

Como segundo critério, a pessoa deveria ter "participado das greves", independentemente da maneira que participou. A organização dos trabalhadores muitas vezes implica em distinções de papéis na participação da greve: comissão de negociação, comissão de fábrica, diretoria do Sindicato, comando de greve. Estas são algumas formas de organização dos trabalhadores para atividades que impossibilitam a participação de todos os

\footnotetext{
${ }^{2}$ A região do Grande $\mathrm{ABC}$, ou $\mathrm{ABC}$ Paulista, se localiza no sudeste da região metropolitana de São Paulo, e engloba as cidades de São Bernardo do Campo, Santo André, São Caetano do Sul, Diadema, Mauá e Ribeirão Pires. Até 1993, havia sindicatos dos trabalhadores metalúrgicos separados por cidades. Assim, havia um sindicato para São Bernardo do Campo e Diadema, outro para Santo André e outro para São Caetano do Sul. Embora ligada a sindicatos diferentes, a onda grevista iniciada em 1978 atingiu toda a região (ANTUNES, 1992). Assim, a princípio, poderiam ter participado desta pesquisa o trabalhador metalúrgico de qualquer uma destas cidades. No entanto, dos metalúrgicos que se dispuseram a conceder entrevista, cinco trabalhavam em indústrias de São Bernardo do Campo (Reinaldo, Wilson, Rafael, Dimas e Nelson) e um em uma indústria de Diadema (Adão). Coincidentemente todos eram ligados ao mesmo sindicato na época das greves.
} 
grevistas. Ou seja, uma negociação com alguns poucos empresários comporta a participação de somente alguns trabalhadores. Há também aqueles que estrategicamente organizam e realizam passeatas, panfletagens, piquetes, arrecadação de fundos, pintura de faixas e cartazes etc., são os que participam das atividades mais braçais, que ficam na retaguarda para que a greve seja viabilizada. Há ainda aqueles que participam de assembleias, reuniões, passeatas, mas sem se envolver diretamente nas atividades estratégicas da greve.

Para a escolha dos depoentes não fiz nenhuma objeção à forma de participação na greve, embora reconheça que há diferenças entre ser ou não uma liderança no movimento, entre estar ou não em certas atividades da greve. Essas diferenças devem ser levadas em conta na análise das entrevistas.

Como se verá a seguir, houve dois casos que os critérios não foram rigidamente seguidos, por circunstâncias do trabalho de campo. Reinaldo estava aposentado havia pouco tempo quando a primeira greve aconteceu em 1978. E Rafael não participou das greves por ter uma função vital para o funcionamento da fábrica (era responsável pela distribuição de energia elétrica). Esses dados foram revelados no momento das entrevistas, e não antes delas, isto é, as entrevistas foram realizadas imaginando-se que esses dois depoentes se encaixavam nos critérios estabelecidos.

No entanto, julgo pertinente manter as entrevistas para a análise. No caso de Reinaldo, houve participação efetiva nas greves, mesmo na condição de aposentado. No caso de Rafael, não foi possível incluí-lo em todos os pontos de análise das entrevistas. Mas em alguns outros, serviu até como comparação dos pontos de vista de quem participou e de quem não participou das greves.

Segue então uma breve narrativa da minha incursão, como pesquisador, no campo e como se deu o encontro com os entrevistados.

\subsubsection{Adão}

No início da pesquisa, entrei em contato com a mãe de um colega meu, chamada Nádia. Nádia participou do movimento Oposição Metalúrgica de São Paulo na década de 1970. Em um encontro, em sua casa, contou-me algumas histórias de sua participação no 
referido movimento. $\mathrm{Na}$ época, ela era estudante universitária e tornou-se posteriormente operária em uma fábrica de Osasco.

Nessa ocasião, Nádia me passou os contatos de Adão, um metalúrgico conhecido seu que atuou em greves no $\mathrm{ABC}$, onde trabalhava. Liguei, então, para Adão para contar sobre minha pesquisa e perguntar se ele desejaria conceder-me uma entrevista. Marcamos um encontro em sua casa.

A primeira preocupação de Adão quanto à entrevista foi o receio que esta se transformasse em matéria para comércio $^{3}$, segundo suas próprias palavras. Ele não queria que seu depoimento servisse para um eventual enriquecimento de outrem. Tranquilizei-o ao dizer que a pesquisa seria publicada por uma universidade pública, e os exemplares da dissertação ficariam na biblioteca da respectiva universidade, com acesso gratuito ao público em geral.

Adão, ao mesmo tempo em que mostrava esta preocupação, disse que poderia confiar em mim por eu ter sido apresentado por Nádia, uma pessoa que conhecia há muito tempo e por quem tem muita estima.

Estas referências no primeiro contato com Adão permitiram que estabelecêssemos, a partir dali, uma relação de confiança e confidência. Todas as vezes que fui a sua casa me recebeu com hospitalidade. Conheci toda sua família. Sempre me ofereceram café, bolo, lanche. E por duas vezes almocei com Adão e sua família.

A entrevista com Adão durou ao todo cerca de oito horas e meia, sendo que foram necessários cinco encontros para realizá-la. Todos aconteceram em sua casa, localizada no bairro Parque Bristol, em São Paulo. Adão trabalhava em Diadema e sua residência, apesar de ser em São Paulo, fica quase na divisa de São Bernardo do Campo. Não sendo longe de Diadema tampouco.

Nas visitas que fiz, Adão geralmente me encontrava no ponto de ônibus e íamos a pé até sua casa, não raramente conversando sobre algum tema relacionado à política ou sociedade. Adão também me mostrava alguns lugares do bairro, como o posto de saúde onde atua como conselheiro, a igreja onde conheceu dois padres de esquerda e a barbearia de seu companheiro de passeatas. Certa vez me apresentou seu companheiro, o Zé. Nessa ocasião pararam para conversar e rememoraram espontaneamente algumas passagens de suas vidas de militante, como o episódio de uma passeata na Praça da Sé, onde a polícia agiu com violência e todos os manifestantes se espremeram na Catedral. Contaram que diante dessa situação um bispo da Igreja Católica negociou a saída dos manifestantes.

\footnotetext{
${ }^{3}$ As falas dos depoentes estarão destacadas no texto em itálico, a partir deste capítulo.
} 
Muitas vezes fui questionado sobre minha opinião a respeito de algum tema, pois Adão se interessava no que eu tinha a dizer sobre a política universitária, ou sobre as greves das quais eu participei na USP; e um certo dia me perguntou sobre minhas posições partidárias. Estas conversas serviram para uma aproximação, criando uma confiança entre mim e Adão, que certamente teve reflexos na entrevista, a qual levou tanto tempo para ser realizada. Ouvir o que ele tinha a dizer foi importante não apenas no momento da entrevista, assim a troca de ideias nos trajetos que percorríamos a pé em seu bairro, ou as que se davam a sua mesa durante o almoço ou um cafezinho, tiveram muito valor.

\subsubsection{Associação dos Metalúrgicos Aposentados (AMA)}

O primeiro contato que fiz com a AMA foi por telefone. A pessoa que me atendeu, ao escutar sobre a proposta da minha pesquisa, sugeriu que eu procurasse um dos diretores da referida entidade.

A sede da AMA, em São Bernardo do Campo (próxima ao Sindicato dos Metalúrgicos do $\mathrm{ABC}$ ), ocupa um prédio de tamanho razoável. A entidade realiza atendimento aos aposentados em relação às questões da previdência social; oferece cursos, bailes, viagens e outras atividades de lazer aos metalúrgicos aposentados; funciona também como um ponto de encontro informal destes; e realiza uma assembleia mensal entre os sócios, geralmente com alguns pontos de discussão na pauta e também uma palestra de algum convidado.

Marquei meu primeiro encontro com F. ${ }^{4}$, um dos diretores da Associação. Conversei com ele sobre o projeto de pesquisa e F. me contou que na época das greves já não trabalhava como metalúrgico, por motivos políticos. Embora parecesse que ele teria muito para contar e que estava desejoso de dar um depoimento, achei melhor procurar outra pessoa, pois ele não atendia aos critérios de escolha dos entrevistados.

Agendei uma entrevista com Wilson, mas ela teve que ser desmarcada por conta de outros compromissos do depoente. Ele me sugeriu que eu entrevistasse G., um outro diretor da AMA. No entanto, foi difícil agendar entrevista com ele, pois ocupava um cargo na diretoria que exigia muito de sua agenda.

\footnotetext{
${ }^{4}$ Não serão citados os nomes daqueles que não concederam entrevistas, pois não foi pedida autorização para tal.
} 
Mesmo sendo difícil encontrar uma data que fosse mais apropriada para G., consegui agendar a entrevista. Porém, na data marcada, quando eu já estava a caminho da sede da AMA, onde seria a entrevista, G. por telefone me avisou que não poderia conceder a entrevista, pois teria que resolver alguns problemas. Diante dessa impossibilidade pergunteilhe se não havia alguém que pudesse me conceder uma entrevista, ele então indicou Reinaldo, outro membro da diretoria da entidade.

Dessa maneira, realizei a entrevista com Reinaldo, em uma sala da AMA onde ficamos à vontade, sem interrupções.

Voltei à AMA, dois meses depois, para procurar alguém que quisesse conceder outra entrevista. Mais uma vez as pessoas indicaram Wilson, o presidente da Associação. Insisti que não deveria ser necessariamente um diretor da entidade; no entanto duas ou três pessoas, para quem perguntei se gostariam de dar um depoimento, responderam que eu deveria entrevistar o Wilson.

Mais uma vez foi difícil marcar um horário com Wilson. Até que finalmente conseguimos marcar um horário, sem haver qualquer desencontro. Cheguei à sede da AMA e Wilson me recebeu na sala da presidência. Conversamos um pouco até que Dimas, um membro da diretoria da AMA, entrou na sala para conversar com Wilson. Wilson, então, aproveitou a oportunidade para perguntar a Dimas se ele não gostaria de dar um depoimento, e a resposta foi afirmativa. Perguntei para quando marcaríamos a entrevista e Dimas disse que poderia ser naquele exato momento. Então, na mesma manhã, entrevistei Dimas e, logo após, Wilson.

Um mês depois voltei à AMA para entregar as transcrições ${ }^{5}$ das entrevistas para Dimas e Wilson. Dimas pareceu muito feliz em ver sua fala transcrita e impressa. Assim que recebeu a cópia de sua entrevista começou a ler.

Logo após, Dimas caminhou comigo pela sede da Associação e apresentou-me a algumas pessoas perguntando, espontaneamente, se gostariam de me conceder uma entrevista. Duas pessoas, que não eram membros da diretoria da AMA, Nelson e Rafael, aceitaram. Marquei para a semana seguinte as entrevistas com os dois, as quais foram realizadas também na sede da entidade.

Apenas no transcorrer da entrevista com Rafael descobri que ele não havia participado das greves. Decidi manter essa entrevista para a análise, apesar de fugir a um ponto

\footnotetext{
${ }^{5}$ Todos os entrevistados receberam uma cópia da entrevista transcrita e autorizaram a publicação da mesma nesta dissertação.
} 
importante do critério de escolha dos entrevistados, pois seria possível fazer uma comparação, em alguns momentos, entre o ponto de vista daquele que não participou do movimento grevista e daqueles que participaram. Como se verá na transcrição de seu depoimento, Rafael não era contra a greve; porém não participou por exercer uma função importante na fábrica, e por correr o risco de demissão se abandonasse seu posto.

F., a primeira pessoa com quem me encontrei na AMA, também não se encaixava em todos os critérios estabelecidos inicialmente para a escolha dos entrevistados. Naquele momento achei melhor não realizar uma entrevista com ele. Entretanto, após entrevistar Reinaldo e Rafael, que tampouco atendiam a todos os critérios, percebi que também poderia ter entrevistado F. , e que seu depoimento poderia enriquecer as análises. Mas já não havia mais tempo hábil para realizar a entrevista, transcrevê-la e incluí-la na análise.

\subsubsection{As diferenças entre as entrevistas}

Como se notará, a entrevista concedida por Adão foi muito mais longa do que as outras. Foi realizada em cinco encontros e durou no total cerca de oito horas e meia. Já as outras cinco entrevistas levaram um encontro cada, e a variação de suas durações foi entre 40 minutos e duas horas, aproximadamente.

As diferenças existiram não apenas no tempo de duração das entrevistas, como também no quanto cada entrevistado ateve-se a detalhes e aprofundou-se em suas lembranças durante as narrativas.

Dois fatores foram decisivos para que houvesse tamanha diferença. O primeiro diz respeito à maneira como conheci os depoentes. Adão foi apresentado por uma amiga em comum, o que, segundo ele, lhe transmitiu plena confiança em mim. Em relação à AMA, cheguei sem conhecer ninguém. Fui conhecendo as pessoas aos poucos, e todas, inicialmente, diziam para eu entrevistar os dirigentes da entidade.

Outra diferença importante foi o local onde foram realizadas as entrevistas. A esse respeito, argumenta Bosi (2003): "Se o local do encontro for a casa do depoente, estaremos mergulhados em sua atmosfera familiar e beneficiados pela sua hospitalidade.” (p. 59). Adão

me recebeu em sua casa, o que o deixou à vontade para lembrar e narrar. Os outros 
depoimentos foram dados na sede da AMA, onde por vezes as pessoas poderiam ter presentes questões e preocupações relativas a sua estada naquele local.

As diferenças entre as entrevistas não impossibilitaram suas análises, mas impuseram limites. Talvez pudéssemos ter tido entrevistas mais detalhadas, se o encontro com cada depoente tivesse sido pautado pela hospitalidade à qual Bosi se refere. Mas a pesquisa de campo, na maioria das vezes, é pautada pela imprevisibilidade.

\subsection{O roteiro}

Uma primeira versão do roteiro foi elaborada para a entrevista piloto com Adão. Esta versão procurou contemplar perguntas que seguissem os objetivos da pesquisa (ver Anexo 1). Assim, esta primeira versão buscava percorrer a trajetória do operário entrevistado, desde seu ingresso no mundo do trabalho, passando pela formação política, até chegar às greves. As perguntas sobre as greves seguiam uma ordem cronológica (1978, 1979 e 1980), que correspondem às três greves analisadas por Antunes (1992).

Com a experiência da entrevista piloto, o roteiro foi reformulado (ver Anexo 2). A ordem cronológica da trajetória do metalúrgico foi abandonada. As primeiras perguntas passaram a ser sobre as greves, por ser este o tema central da pesquisa. As questões deixaram de ter o enfoque sobre as greves que aconteceram em um ou outro ano. E o número de perguntas foi reduzido.

$\mathrm{Na}$ entrevista com Adão, o roteiro não foi seguido à risca. Serviu mais como um estímulo para suscitar as narrativas sobre os temas. Muitas perguntas foram contempladas sem serem feitas. Enquanto que para a entrevista com Reinaldo foi usada a segunda versão do roteiro. Foi esta versão que usei nas demais entrevistas.

Apesar das diferenças entre as versões, a entrevista com Adão não fica invalidada. Como se verá, foi uma entrevista rica e será utilizada na análise da pesquisa. 


\section{AS ENTREVISTAS}

A transcrição das entrevistas é apresentada a seguir. Todas as entrevistas foram gravadas em fita cassete e transcritas pelo próprio pesquisador. Cada entrevistado recebeu uma cópia da transcrição. Todos autorizaram a publicação na íntegra, inclusive a publicação de seus nomes.

Durante o processo de transcrição, houve a tentativa de manter o texto o mais próximo de como foi falado, e, ao mesmo tempo, de adaptá-lo da melhor forma possível para a linguagem escrita.

Algumas vezes não foi possível entender uma palavra ou outra na gravação em fita cassete. Nesses casos, foi feito algum tipo de emenda na frase para que o texto permanecesse fluído, sem prejudicar a essência do conteúdo.

As entrevistas estão apresentadas conforme a ordem em que foram realizadas.

\subsection{Adão}

Como mencionado no capítulo anterior, a entrevista de Adão foi feita em cinco dias diferentes. Ela será apresentada dividida nas cinco partes correspondentes.

\subsubsection{Parte 1}

Onde você nasceu, Adão?

Eu nasci em Pinheiros Altos, Minas Gerais, no ano de 1941.

Na década de 70, você morava onde?

Na década de 70 eu já vim morar em São Paulo. Eu vim para São Paulo em fevereiro de 1969. Eu comecei a trabalhar na metalúrgica aqui em São Paulo, na Rua Jussara, 272, no Bosque da Saúde. Iniciei lá no dia 17 de março de 1969, como ajudante. Meu nível de 
escolaridade era o segundo ano primário. Sentia necessidade de correr atrás de aprender um pouco mais. Não tinha escola pública pra gente. A gente freqüentava algumas escolas particulares. Aí consegui alfabetizar um pouco melhor. E continuei trabalhando nessa fábrica. Aqui em São Paulo, no endereço que eu citei, trabalhei até mil novecentos e setenta e... setenta e seis. No início de 76, fui para essa mesma fábrica. Ela foi transferida para o $A B C$. Não podia mais permanecer aí devido ao... se tornou um bairro nobre, não podia mais fazer barulho ali. Ela já tinha feito os barulhos que tinha, levou punições, essas coisas todas, e aí, com o incentivo que abriu no $A B C$, eles foram pra lá, e levaram.... até na época, isso foi em 76, nessa época eu já tinha feito, como eu já te disse, tinha passado por um processo de melhorar um pouco a alfabetização. Corri atrás de um curso profissional, que na época não tinha assim como tem hoje, tantas oportunidades. Eu paguei uma escola particular, na Avenida Dom Pedro. Fiz um curso de manutenção e instalador. Peguei o certificado. Propus para a direção da empresa, no caso, que eu queria estar mudando de área. Trabalhava no setor de montagem. Quando trabalhava no setor de montagem e fiz este curso, eu achava melhor mudar para a área de manutenção, no campo de elétrica, que era o campo que eu via que queria expandir, crescer um pouco mais. Fui barrado pelo chefe do setor, que disse que não aceitava peão da fábrica para ser transferido. Preferia pegar gente de fora que pegar peão lá da fábrica. Aí um dos diretores da empresa foi claro para mim. Disse que não poderia contrariar as vontades dele e fazer a minha. Permaneci nesse mesmo setor. Pedi a conta, não aceitaram. Pedi a conta outra vez, não aceitaram. Como eles estavam montando esta unidade lá em Diadema, um dos diretores me fez uma oferta, que na época eu era líder. Me fez uma oferta que precisava de alguém para coordenar um trabalho no setor de galvanoplastia. Eu não conhecia nada disso, era um palavrão. Mas eu queria sair. Como não teve acordo algum para eu sair, acabei aceitando essa proposta, esse desafio. Acho que foi mais um desafio. Acho que o objetivo dele era desafiar mesmo a gente. Fui pra lá. Comecei a trabalhar nessa área. Um fato muito interessante, e faço questão de frisar isso aí, é que um senhor de idade, negro, foi quem me ensinou tudo que eu tinha que fazer nessa área. Eu tive muita sorte, nesse ano de 76, eu fui pra lá, e tinha esse senhor da raça negra, tinha uma certa idade, tipo uns 55 ou 60 anos. Mal assinava o nome, mas era uma pessoa fora de série. Nem sei se está vivo ainda. De vez em quando fazíamos contato, infelizmente perdi contato com ele ultimamente. E o químico, que coordenava o trabalho disso, ele viu a minha força de vontade, percebeu essa força de vontade, e começou a me treinar também na área química. Então fui muito favorecido nessa época. Fui muito favorecido nessa área devido a eu ter, de um lado, quem botasse a mão na massa para fazer a coisa, que era esse senhor, Sr. Roberto Lima, e seu Osíris Rezende, que era o químico. Ele ia lá duas vezes por semana, e o resto ele me passava por telefone. Até os métodos de fazer análise, e essa coisa toda. E comecei a coordenar um trabalho de galvanoplastia, que é um sistema de eletro-reposição de superfície metálica.

E isso foi avançando nessa parte em 76. Um amontoado de gente, a fábrica em péssimas condições, não tinha basicamente nada. Banheiro, assim, ridículo. Não tinha papel higiênico, não tinha água filtrada, não tinha nada. Restaurante nem se fala, café nem se fala. Complicado. Foi um pouco esse tipo de vida que a gente levou no início dessa nova etapa, quando saí do setor de montagem para ir para uma outra área de nome galvanoplastia. Então, nessa luta toda acabei fazendo cursinho, através do SENAI aqui no Brás. Por incrível 
que pareça, isso veio a ocorrer em 79. Depois a gente volta um pouco para falar dessa data. Só pra basear um pouco como foi a trajetória da gente nessa área. Nesse cursinho, um dos critérios era que você tinha que estar trabalhando na área, ou ser um profissional qualificado nessa área pra fazer esse curso no SENAI aqui do Brás. Um cursinho pequeno, deve ter a ficha de freqüência, deve estar guardada nos meus arquivos aí ainda. Então vinha gente de algumas cidades vizinhas para fazer esse curso. E o único que não tinha formação era eu. A maioria do pessoal que freqüentava, você tinha pessoas formadas em engenharia química, técnico, esse pessoal todo. Mas eu me dediquei bastante, pedi ajuda a um colega que era da firma. Ele me ajudou bastante a fazer os trabalhos. No fim eu sei que tive uma nota boa nesse cursinho. Recebi o certificado, e saí com uma nota boa. Isso me ajudou muito. Mas eu nuca parei. Fiz o curso de elétrica, depois de técnica em galvanoplastia, em laboratório e supervisão, e depois fui fazendo outros cursinhos.

Aí, voltando um pouco pro nosso início lá no ABC. Como aqui em São Paulo, na época que comecei a trabalhar, que foi em 69, a questão de você se filiar no sindicato, já era uma coisa assim que você não precisaria ir no sindicato para se filiar, nem o sindicato vinha até você. Já tinha ficha na empresa. Quando você ia ser registrado, já fazia sua filiação no sindicato automaticamente, já era o sindicato tudo junto com a empresa ali. O próprio recursos humanos já fazia um monte de propagando do sindicato - de São Paulo, no caso, eu estava em São Paulo nessa época - que a gente tinha acompanhamento médico, colônia de férias e tantos outros benefícios. Bom, mal cheguei do interior, tinha pouca experiência, $e$ tudo bem, fiquei sócio automaticamente. Indo pro $A B C$, eu transferi do sindicato de São Paulo pro sindicato de lá. Já tinha o sindicato no ABC, mas estava começando a se discutir isso. Me lembro bem dessa questão do ABC, pelo fato de eu liderar o setor, mesmo com as limitações que eu tinha, a gente foi chamado para algumas reuniões com a direção da empresa, aonde eles colocaram a preocupação que eles tinham com a questão... tem que citar o nome da pessoa, que no caso era o Lula na época. Os boatos que andavam... em 76 eu não tinha tanto contato com ele, eu fui conhecendo através desses papos de reunião lá na empresa. $O$ diretor industrial nos reuniu e disse: "Olha, vamos tomar muito cuidado que tem um nordestino aí, barbudo, que está com uns discursos de comunista”. Isso foi em 76. "Ele está fazendo de tudo para ganhar as eleições do sindicato aqui no ABC e formou um novo sindicato aqui no ABC". Isso foram palavras do diretor dessa empresa. "Se ele ganha o sindicato aqui no ABC pode acontecer um monte de coisas ruins". Aí ele citou: "Pode haver um monte de desemprego, um monte de firmas podem ir embora. Porque vocês imaginam, um comunista... não vai dar certo isso aí. Vamos ver no que vai dar. Então vocês fiquem atentos com o pessoal que trabalha com vocês. E vocês fiquem atentos com o que pode acontecer se ele vier a ganhar esse sindicato". E aí eu procurei me informar que tipo de coisa era essa. Como já era sócio "automático" - de São Paulo me transferi pra lá - eu disse "Poxa, vou precisar conhecer isso melhor". E aí tentei procurar conhecer isso aí, aí que eu fiquei sabendo que o Lula - Luís Inácio Lula da Silva, mas todo mundo o conhecia por Lula - fez uma reunião com o pessoal que compunha a direção do sindicato lá do ABC que não era simpático à maneira como o Sindicato dos Metalúrgicos de São Paulo era conduzido. Essa equipe se reuniu. Nessa época o Djalma Bom era o presidente, ou diretor. Não me lembro exatamente o cargo que ele ocupava lá, era representante dos trabalhadores nesse sindicato. O Lula sentou com ele e disse o seguinte: "Olha Djalma, nós precisamos montar uma chapa, 
conversar com o pessoal nas portas de fábrica, e com isso a gente ganha a direção desse sindicato para a gente dar um rumo neste sindicato. Que a gente ter um sindicato para ficar descontando mensalidade e não estar a serviço dos trabalhadores não faz sentido. Ou a gente muda esse sindicato para ele ser um instrumento para os trabalhadores, ou vai deixar de existir, porque do jeito que está não tem utilidade nenhuma. Só tirar dinheiro das pessoas com essas histórias de assistência médica e colônia de férias e essas babaquices todas aí. Então isso não serve, não é o modelo de sindicato ideal. O pessoal aqui do ABC está crescendo muito, muitas indústrias estão vindo, e nós precisamos ganhar este sindicato $e$ mudar os rumos dele". E aconteceram estas eleições, o Lula venceu, ficou sendo presidente desse sindicato, e eu continuei aí observando, ouvindo o que acontecia dentro da empresa e acompanhando também o movimento dentro do sindicato. E aí o bicho começou a pegar e a pegar feio a partir de 76 pra cá. As preocupações que tinham, tanto os patrões de um lado, e os trabalhadores ainda não muito informados, ou seja, bastante desinformados ainda, sobre esta questão, estava ainda em processo de formação... Até a empresa que eu trabalhei não teve muita participação pelo tamanho. Pelo número de trabalhadores que tinha lá, o sindicato não chegou a priorizar tanto isso nessa época, então eles tentaram centralizar força mais nas grandes empresas. A Scania e a Mercedes-Benz foram o foco das maiores discussões que teve, as primeiras greves que teve, essas coisas todas. E aí essa coisa foi se alastrando, foi ganhando nome, foi apresentando resultado, foi ganhando adesão de outras categorias, de diversos setores, e foi crescendo. Aí a repressão era contínua. Quanto mais evoluíam as discussões dos trabalhadores e a participação, maior era a perseguição por parte das empresas, por parte da polícia. Na época a gente estava no regime militar, o autoritarismo. Então os caras não mediam esforços para meter o pau, não. Você tinha que fazer essas reuniões um pouco camuflado. Os convites para a pessoa participar de uma reunião tinham que ser feitos de uma maneira bem discreta. Porque já começou a nascer os "olhão" dentro da firma para ver quem se destacava mais com esse movimento; já estava convidado a deixar de participar, sobrava. Muito complicada essa situação. Essa coisa foi se alastrando, ganhando maior dimensão e acabou virando uma coisa monstruosa. E isso veio a pegar uma intensidade de maior volume a partir do ano de 78. Porque em 77, como eu te disse, as duas partes ainda estavam um pouco indecisas. Ou seja, não sei se é indecisão. Mas estudando como lidar com isso aí. Do lado dos trabalhadores, se preparando para ir para o enfrentamento. Do lado das empresas eles se muniram para saber como enfrentar essa problemática. Muito embora o clima era muito tranqüilo ainda para quem tava no poder, que tinha os militares, tudo estava sob comando deles, eles davam todo o apoio. Era só dar um apito lá que chegava a moçada toda pra se envolver...

Foi mais ou menos assim, Guilherme, até o ano de 78. Aí depois a gente pode estar falando pra você como é que foram as organizações, as conquistas que a gente foi obtendo através de muita luta, greves, muitas demissões, prisões, mortes, tudo isso aí que a gente acompanhou, presenciou algumas, participou de algumas. Foram anos bastante complicados. Ninguém estava preparado para estas coisas. De repente você tinha que automaticamente fazer isso. Você não podia estar distribuindo jornalzinho na porta da fábrica, se não os caras prendiam. Mesmo na rua pra você distribuir isso tinha que montar um esquema, senão, não funcionava. Você colocava debaixo do braço, ou coisa parecida, deixava cair, o colega que vinha atrás tropeçava, aquilo espalhava, o outro pegava e a notícia começava a espalhar. 
Você não podia distribuir. Tinha espião em vários lugares e te engaiolavam mesmo e ninguém poderia garantir que você voltava com vida, não. Se os caras pegassem, era muito difícil sair vivo. Você era enquadrado como comunista. Foi mais ou menos nesse contexto que o nosso sindicato de São Bernardo nasceu. E aí o que acontece? A partir de 78 começou a acontecer o crescimento da participação das pessoas. Não posso dizer com muita certeza se é consciência ou se é conseqüência do que estava se passando naquela época, o salário sendo achatado, sem direitos quase nenhum. Acidentes de trabalho: isso é o que mais rolava, e era tudo camuflado. Então fica até difícil eu falar pra você: o pessoal começou a tomar consciência. Ou não... corrigindo: eu acho que o pessoal começou a tomar consciência, mas naquele momento você não pode dizer que era um pessoal que estava fazendo a coisa conscientemente. Eles começaram a tomar consciência a partir desses acontecimentos. Cada acontecimento era pra nós, eu e tantos outros colegas, uma etapa de aula que a gente teve. Na luta que a gente ia, cada acontecimento era mais uma lição que você aprendia para dar os próximos passos. A gente tinha que ter bastante jogo de cintura para driblar os espiões dentro da firma, e conseguir participar desse movimento muito camuflado. Estas reuniões tinham que ser feitas em lugares não divulgados, senão tinha muitos observadores que traziam informação. No meu caso, não chegou a pesar muito devido ao tamanho. Nós éramos na época 1.400 funcionários. Mas como a Mercedes, a Volks, a Scania, outras firmas nas imediações ali, tinham um volume muito grande, então a perseguição maior era por lá. A gente ia, como se diz, no contrapeso, só para somar. Mas de repente começou a despertar interesse de estar trabalhando com o pessoal que já tinha avançado um pouco na consciência. Começou a despertar um pouco a questão de também fazer este trabalho em fábrica do porte dessa que eu trabalhei esse tempo todo da minha vida profissional.

Mas muitas coisas, Guilherme, ocorreram. Muito, muito mesmo. Assisti muitas prisões, agressões, demissões, e muita coisa que a gente conseguiu presenciar que fica até difícil você lembrar detalhe por detalhe. Mas a partir daí começou a pintar aquela questão de fazer a formação das pessoas. E isso já não ocorria ali na sede do sindicato, pois sofria intervenção. Mas então a gente fazia em alguns porões, em algumas garagens. Salas quase não existiam naquela época, a maioria dos operários eram só quarto e cozinha. Não tinham como, era muito difícil viver. Então essas discussões ocorriam em finais de semana. A gente batia uma bola, trocava idéia. Começamos a estar discutindo essas questões. Foi nascendo esta idéia. Começou a ter as associações de bairro. Aquelas que tinham alguém já voltado para este idealismo do mundo do trabalho, sindicato, essa coisa toda, fazia uma coisa bem feita, mas com jogo de cintura também para evitar prisões. Tinha espiões também. Tive o privilégio de estar fazendo isso aqui no meu bairro mesmo. Vinha o pessoal já com mais informação e passava para gente. Começaram a mostrar para a gente a questão do capital versus trabalho, que era dado outro nome, que era mais-valia. Com isso a gente aprendeu bastante, muitas pessoas aprenderam bastante. Aí começaram a mostrar em termos de números, faziam algumas simulações para saber quanto você rendia de lucro para trabalhar na empresa. Já vinha a informação de como os metalúrgicos de países desenvolvidos viviam. Era bem diferente do nosso mundo aqui.

Já no final de 78, 79, como eles tinham o instrumento, o aparelho do estado do lado dos patrões, quando a coisa fervia muito, inchava... vamos falar assim: a panela ficava inchadona com a pressão dos operários, os militares iam lá e intervinham. Prendiam. O Lula 
mesmo foi preso, e outros tantos militantes do sindicato. Prendiam, fechavam a sede e a gente tinha que se virar. Eles fechavam a sede e a gente corria para outro lugar e ia fazer movimento nas garagens das casas, nos porões... praticamente não existia garagem, quase ninguém tinha carro. Era coisa difícil ter carro. $O$ carro não estava ao alcance de quem trabalhava como metalúrgico que ainda não tinha conhecido tanto ferramenteiro, que foi o pessoal que mais teve salário alto na época, ou torneiro mecânico, que nessa época tinha muito. Esse pessoal foi o primeiro a comprar carro. Mas não se pensava nem em garagem. Era uma questão mesmo de porões, e casas de amigos, para evitar mais prisões que aconteciam se você fizesse em outros lugares. Já em 78, 79, como aconteciam essas intervenções no sindicato, nossas greves quando iam para julgamento, todas elas eram consideradas abusivas, que feriam a lei, ou coisa parecida, aí era demissão uma atrás da outra. Complicava, foi intimidando o pessoal. Aí começou a nascer uma organização maior. Pensamos: "Puxa, tudo que a gente consegue, de repente vem alguém aqui e pára, fala que isso fere as leis, e vai tudo por água abaixo, e começa tudo de novo. Aí vai companheiro preso, perde emprego, companheiro é assassinado e essa coisa toda." Aí nasceu a idéia de começar a discutir como fazer para desmontar isso. Então o primeiro passo precisaria tentar mostrar para a população que aquele sistema que a gente estava vivendo de autoritarismo não funciona. Foi uma primeira análise, estar mostrando passo a passo esta questão do pessoal que usava e abusava do poder. Parece que essa coisa foi sofrendo pressão, pressão, pressão, pressão... não só interna, mas começou a ter uns reflexos externos também, então começou a ter uma pequena abertura, que para nos foi uma coisa boa. Aí a gente ganhou força para fazer uns movimentos bem elevados mesmo, já pensando em desmontar o regime autoritário e ver qual o caminho a ser percorrido a partir daí. Essas discussões, por incrível que pareça, a gente com o trabalhador, no local de trabalho. A questão dos direitos, que estavam sendo afetados, as condições, essas coisas todas. Mas, começou a se perceber que com esse pessoal no poder só estava acontecendo mais mortes. Aí pintou então esta idéia de estar trabalhando esta questão de derrubar esse sistema. Depois golpe de 64, a gente teria que desmontar isso. Parece que eles também se sentiram um pouco perdidos no poder, e com a pressão que foi feita eles foram cedendo até... que aí não foi só o nosso sindicato do $A B C$ que contribuiu, houve várias contribuições. Movimentos de bairro, militantes. Nós fizemos aqui no nosso bairro a "passeata da panela vazia", um panelaço. Fizemos com o pessoal que estava passando fome. Imprensa veio registrar, mas depois não dava certo. Aí houve grandes manifestações em ruas, em estádios. Teve uma vez que estávamos em uma manifestação em São Bernardo, lá na Vila Euclides, e parece que o Lula já tinha ganhado um popularidade muito grande. E foi muito emocionante o acontecimento, e de repente sai uma foto na "Folha de São Paulo" que mostrava o Lula lá com o microfone e aquela multidão de gente ouvindo ele. Se tornou um grande líder a partir daí. Todo mundo atento, seguia rigorosamente as orientações dele, porque percebeu que o cara tinha uma idéias que levavam a gente a algum lugar que a gente desejava. Se tornou uma pessoa muito importante para nós. A nível de sindicalista, é o que o Brasil não teve e não sei se vai ter um como esse cara. E numa manifestação nós estávamos na Vila Euclides, ainda quando os militares... não me lembro exatamente se foi em 79... a coisa ficou feia, rapaz. Olha! A ordem lá de cima era para que não acontecesse essa manifestação. E os diretores do sindicato e todos os trabalhadores entendiam que tinha que acontecer. Aí fomos para a Vila Euclides. Aquilo ficou de um jeito 
que não dava nem para andar. Começaram as falas. Daí a pouco chegou a tropa aqui de São Paulo. O Maluf estava no poder na época, era governador biônico. E mandou a tropa toda daqui para lá para descer o pau, nos dispersar, descer o pau. Tinha cachorro, cavalo, e muitos caras à paisana no meio para tentar agarrar um aqui e agarrar outro ali. Além do pessoal com equipamentos oficiais dos poderosos, tinha também o pessoal que estava disfarçado. Esse dia houve um derramamento de sangue em São Bernardo que eu achei que iria marcar legal a bandeira do Brasil. Um derramamento de sangue dos maiores que a gente poderia imaginar. Mas tivemos a felicidade de um cidadão de nome Tito Costa, que era o prefeito de São Bernardo na época, ele subiu na escada, pegou um megafone (não tinha carro de som naquela época). Subiu na escada e ordenou que o comandante daquela tropa retirasse aquela tropa dali. Ali estava acontecendo uma manifestação de várias pessoas, tinha muita criança, mães, e não era justo que as coisas andassem daquele jeito. E colocou a seguinte fala: "Olha, na cidade de São Bernardo, eu sou a autoridade máxima porque eu sou o prefeito, e eu não solicitei a ajuda de São Paulo. Portanto eu sugiro que o comandante dessa tropa se retire imediatamente ou ele, junto com quem mandou ele para cá, se responsabilizará por tudo. E gostaria que a imprensa registrasse isso, se é que tem alguma imprensa por aqui, que eu, Tito Costa, prefeito de São Bernardo, estou ordenando que a tropa vinda de São Paulo, se retire para evitar maiores problemas. Caso contrário, o comandante, junto com o governo de São Paulo, responderá pelos acontecimentos." E aí ele fez o toque de recolhimento, retirou o tropa. Porque a gente também não ia deixar barato, já tinha combinado com o pessoal, que a gente não ia provocar, mas não ia aceitar provocação. Se era para quebrar o pau a gente ia quebrar mesmo. Já tinha alguns esquemas para entrar no enfrentamento. A gente sabia que não era fácil, ia ocorrer um grande derramamento de sangue se não houvesse essa intervenção do então prefeito de São Bernardo. Se foi bom ou foi ruim são outros quinhentos, mas se muitas vidas se salvaram, se deve à posição desse cara que acho que agiu na hora certa. No meu ponto de vista, né? De repente, não está certo. Mas no meu ponto de vista ele evitou que muitas mortes acontecessem. Com certeza ia morrer gente inocente. Não ia dar para separar quem é quem. Ia ser uma guerra mesmo.

Com isso aí a tropa saiu. A gente conseguiu continuar e terminar o ato. E começou, como eu citei em algum momento, a gente começou a pensar como estruturar os trabalhadores, as associações, a população toda. E esse regime que a gente estava vivendo não dava mais. Estava a serviço de uma pequena parcela da sociedade e massacrando a maioria. Aí começou a trabalhar essa questão, ver se conseguia derrubar os militares. Como eu já te disse a gente não pode ser tão ingênuo de pensar que a gente tomou. Não foi bem assim. Acho que eles sentiram também que fracassaram. Durante esses mandatos deles muita coisa estava sendo registrada, essas mortes clandestinas que aconteciam, esquadrão da morte e tantas outras coisas. Isso aí estava dando um reflexo já muito grande e eles foram bambeando pouco a pouco. Foi até aonde o Geisel disse que quem sucedesse o governo dele já estaria abrindo... Não sei se foi o Geisel ou o Figueiredo, mas parece que a proposta era que o Geisel passava para o Figueiredo e a sucessão do Figueiredo já seria feita via outro sistema, não seria nomeado mais. Aí foi aquela discussão toda onde a gente não teve eleição direta, foi o colégio eleitoral, onde entrou na disputa o governo biônico de São Paulo que era o Maluf. Ele disputou no Congresso Nacional com o Tancredo Neves. Essa parte acho que você já conhece bem, como foi esse processo. É que não consigo falar para você só do 
movimento sindical sem misturar. Estou falando para você coisas que eu vivi, que a gente presenciou no dia-a-dia. Foi aonde aconteceram todas essas coisas. Nós fizemos várias manifestações, passeatas para agilizar e forçar mais rápido a saída desses caras do poder. Com a eleição do colégio eleitoral, ou seja, na disputa entre o Maluf e Tancredo, o Tancredo falava que era do lado... sei lá, maleável, do povão, da democracia, ou coisa parecida. O Maluf, linha dura. Entre os dois acho que não tinha muita diferença, acho que só mudava o discurso. Até me lembro que perguntaram pro Maluf se ele vencesse, que destino ele daria pro Tancredo Neves. Ele falou: "O Tancredo Neves já tem um cargo determinado pra ele. Tão logo que terminar o processo, vou mandar ele pra ser embaixador em Roma. Eu vencendo mando ele pra Roma, e se eu não vencer, o Tancredo Neves não governa”. O que ele quis dizer com isso já não consigo entender, já fica um pouco complicado. [risos]

Mas nós metalúrgicos continuamos nossas lutas, nossas greves, tentando buscar nossos direitos. Redução de jornada de trabalho, reposição das perdas salariais. Para você ter uma idéia: naquela época não tinha aquele negócio de licença paternidade, licença maternidade era pouquíssimo tempo, quase não tinha. A questão da higiene: a saúde no local de trabalho também não tinha. Água: não vou nem falar de água gelada, hein! Água filtrada não tinha. Bebia água da torneira. Banheiro: se você quisesse papel higiênico e pudesse comprar, tudo bem. Se não, se virava com jornal mesmo. Não tinha jeito. Bacia de banheiro nem pensar, tinha aquele outro modelo que você tinha que se agachar. Limite de hora de trabalho e hora extra: não tinha limite. Você tinha que fazer o tanto que precisasse, senão você era substituído. Estabilidade: não tinha. Direito de participar desses movimentos: era participar e ir embora pra rua. Não tinha também. Pelo menos o local em que eu trabalhei era assim. E não era diferente em outras fábricas do mesmo porte, que eu conversava com meus colegas. $O$ único pessoal que gozou um pouco de privilégio de ter seus direitos assegurados, não pela lei, mas de outro forma, porque isso ia virar lei mais tarde, era os das firmas grandes. A Volks, a Scania, a Mercedes. Essas firmonas assim, era mais tranqüilo. Mas em firmas de menor porte se você se identificasse com essas bandeiras de luta você sobrava mesmo. Não queriam nem saber se você tinha dívidas, se tinha família. Não interessa, você sobrava. Um fato que aconteceu também foi que com esse novo sindicato voltado na época para nossos interesses, começou a ter observadores daqui de São Paulo, que iam fazer observação no ABC. Fingiam que eram também das mesmas idéias. Não sei se eram contratados pelas empresas ou pela polícia. Não sei quem contratava. Tinha algumas pessoas que se infiltravam fingindo vestir a mesma camisa que a gente. Depois que eles obtinham todas as informações, eles passavam essas informações para as áreas superiores, $e$ de repente você sobrava. Você era chamado no Recursos Humanos, que na época era chamado de Departamento de Pessoal, e "Olha, infelizmente não vamos precisar mais de seus serviços”, pronto, um abraço, já era. Então, de direitos, que eu estava te falando, paternidade não existia, acho que no máximo um dia, a maternidade era muito reduzido. Esse negócio de dar de mamar pro filho era conversa torta, mesmo porque quase não tinha mulher. As mulheres começaram a trabalhar mais nas fábricas, principalmente no $A B C$, de 78 pra cá. Tinha pouquíssimas mulheres. Eu me lembro em 76, eu fui trabalhar lá, de 1.400 profissionais, o máximo que tinha lá eram umas 20, 30 mulheres. Depois que começou a aumentar mais. Esse negócio de multa do fundo de garantia, não tinha. Os pagamentos eram 
feitos a cada dia 10 de cada mês. Os aumentos, a gente nem sabia aonde eram feitos. De ano em ano eles estipulavam um valor e bom, tinha um aumento de tanto. Isso quando tinha.

E a coisa rolava mais ou menos nesse caminho. Foi muito complicado. Com a questão que eu te falei do Tancredo Neves, houve aquele rebuliço todo, assume o Sarney, e virou aquela coisa toda. Era gozado, eu me lembro... até tenho uns arquivos aí, preciso procurar isso aí ainda... um livro onde aparecia o Lula com uma chave de fenda combatendo o Sarney fantasiado de dragão. Era uma briga legal essa daí. [risos]

Então com essa coisa do Sarney ter assumido o lugar foi que nossa luta continuou. Com essas coisas aí a gente conseguiu, como já era um governo que não foi nomeado, mas foi eleito pelo Congresso, mas a gente nunca perdeu de vista de quem ele estava a serviço. Mas de uma forma ou de outra, moderaram um pouco as represálias. Não sei se foi mais por causa do nosso movimento. Não dá para entender claramente isso aí. Se o Sarney tinha outras pretensões, o que acontecia. Como tudo que a gente fazia, como eu disse: o sindicato sofria intervenção, tudo que a gente tinha conquistado em assembléia ia por água abaixo, e a gente ia pra estaca zero. Tudo via lei. Aí nasceu a necessidade de intervir mais em cima. "Bom, nós vamos precisar ter representantes dos trabalhadores na composição das leis, porque essas leis não estão servindo pra mais nada. Estão uma tranqueira. Estão servindo bem para quem as criou." Foi aí então que nasceu essa idéia de estar discutindo um partido dos trabalhadores para estar elegendo trabalhadores que fossem até o Congresso tentar barrar essas leis que poderiam detonar muito fácil nossas conquistas, jogar tudo por água abaixo. Pensamos assim: "Tudo está sendo feito em cima da lei, então precisamos colocar alguém que possa ajudar a elaborar essa lei." Aí então surgiu a idéia de criar o Partido dos Trabalhadores. Bem antes disso, um personagem conhecido como João Ferrador, que mandava várias cartas pro Geisel, pro Figueiredo, fazendo denúncias, criticando o que acontecia. Eu sempre gostei de guardar essas coisas, esses livrinhos. Eu devo ter guardado em algum lugar, posso estar procurando e passar pra você. Eram umas críticas que ele fazia, muito legal. Mandava, questionando o "Excelentíssimo Fulano de Tal”. Ia por aí, fazendo aqueles questionamentos e tudo.

Bom, daí nasce o PT. Com uma proposta linda, maravilhosa, que a gente poderia, se seguisse aquilo ali, dar certo. A principal maneira era a mudança de sistema. O capitalismo pra gente não ia ter jeito. Eu, por exemplo, nunca perdi isso de vista, até hoje. Está aí o partido no poder, está a porcaria que está. Saiu lá do princípio; este partido que está no poder não é o que nós criamos. Era um partido com outro objetivo. Não era fazer essas besteiras que são feitas. Até queria voltar um passo a uma reunião que eu tive aqui no Ipiranga, com outros companheiros. Foi uma assembléia regional que trouxe várias pessoas do ABC para participar. E o Lula estava nessa. Até me lembro, numa manhã, ele com a camisa listrada, aquele jeitão dele, com o charuto dele, o chapéu de palha. E eu, como o conhecia bem, cheguei nele, pus a mão no ombro dele e falei: "Ô., Lula. Por que você não desiste dessa idéia de ser candidato a presidência da república? Porque você é a pessoa que a gente mais se orgulha, e o mundo todo te conhece, como um grande líder que nasceu no ABC.Era engraxate, passou por um processo de ser torneiro mecânico, e tantas coisas que aconteceram na sua vida. Ninguém tira esse rótulo seu. Ninguém pode lhe tirar esse mérito que foi conquistado ao longo do tempo. Não é estranho, e você sabe disso, que alguns amigos seus não tiveram a mesma sorte que você. Foram presos, perderam o emprego, separaram da 
família, passam fome, ninguém sabe o destino deles. E você, graças à sua luta, essa coisa toda, e o esforço de outras pessoas, se tornou uma figura conhecida mundialmente, questionada mundialmente. E nós temos um grande orgulho de ter um Lula igual você, representando nosso sindicato, com todas qualidades que você tem. Por que você não abre mão de ser presidente da república? Porque, se eu não estou enganado, várias vezes nós conversamos, e chegamos a uma conclusão: com o sistema capitalista, ninguém consegue melhorar isso, não. Primeiro tem que derrubar o sistema. E, pelo que nós percebemos aqui e agora, está muito longe de isso acontecer ainda. Eu acho que você vai estar queimando etapa". Aí a resposta dele foi direta pra mim: "Olha, eu vim pra uma assembléia aqui na sede do Ipiranga, não é pra tratar desse assunto. Eu acho que você deveria tratar desse assunto nos diretórios do partido, ou em diferentes instâncias. Vai na instância que você acha que deve ir, porque hoje já não sou eu quem decide. Quem decide isso é a direção do partido". Eu disse pra ele: "Olha, Lula. Eu lamento muito que isso está acontecendo. Boa sorte. Eu não estou nesse barco, não”. Isso muito antes de ele ser eleito presidente da república. "Eu lamento que isso está acontecendo, e até lembrando o sangue de alguns amigos nossos, que você sabe, derramaram. Exemplo: o Santo Dias, em Santo Amaro, assassinado brutalmente, um grande amigo nosso". Acabou o pessoal chamando a gente lá pra dentro, e fomos fazer assembléia, tratar de um assunto de movimento popular.

A partir daí não cruzei mais com o Lula. Participei de alguns eventos, comícios, essa coisa toda. Mas, com a penetração desses espiões dentro do nosso sindicato pra dedurar a gente, e esse sindicato aqui de São Paulo dirigido por... o Joaquinzão na época, acho que era o Joaquinzão. Um amigo nosso, concorreu com ele, ganhou as eleições. Foi o Anísio Batista, morador aqui da região. Concorreu ele, o Santo Dias, o Valdemar Rossi [na mesma chapa]. Ganharam, mas não levaram. Os militares botaram fogo em parte das urnas e deram posse pro Joaquinzão. Então nasceu a necessidade de criar uma central pros sindicatos, com uma outra linha de ação que não fosse atrelada ao Estado, como esse de São Paulo. Aí nasceu a CUT. O PT nasceu em 80... fim de 79, 80. Com o objetivo de levar a gente pro Congresso, para a elaboração de leis, e até a possibilidade de uma nova constituição. Aquela constituição, para a gente, não estava servindo mais, estava muito defasada. Então nasceu o partido com esse objetivo. Como eu te disse, a gente tinha um objetivo com esse partido. Não é isso que está acontecendo hoje, de forma nenhuma. Guarda bem isso: não é isso que a gente queria. Não me sinto responsável por isso, de forma alguma. Porque nós criamos um partido com carta de princípio. A gente tinha um objetivo, a gente sabia onde queria chegar. Isso ia custar muitos outros trabalhos, outras conseqüências, com certeza ia, porque ninguém ia querer entregar o sistema, que favorece tão bem poucas pessoas, de mão beijada. Iria ser muito sacrifício. Mas eu e alguns amigos que conheço nunca perdemos de vista isso.

Com essa questão dos espiões desse outro sindicato, ligado ao patrão, em São Paulo, começamos a discutir a criação de uma central para substituir isso aí. Nasce a Central Única dos Trabalhadores, a CUT. Também com uma maravilha de projeto. Durante um bom tempo a gente tinha bastante esperança que isso ia dar certo. Aí vieram vários presidentes. Quando terminou o mandato do Lula de presidente de sindicato, veio o Menegueli, veio o Vicentinho, e tantos outros. Iam pulando do sindicato pra CUT. Foram pulando de galho em galho até chegarem aonde eles estão. No caso do Vicentinho, é deputado. Parece que é vice do Suplicy. O Menegueli é chefe não sei daonde, do departamento de sindicato da indústria. E foi por aí. 
A CUT hoje também não representa nossos interesses mais, não. Ela ficou tão ruim quanto o Sindicato de São Paulo. Porque hoje ela obedece rigorosamente às doutrinas do governo federal. Ela está a serviço do governo federal e não dos sindicatos que ela representa. Ela chegou a ser o maior... o maior não, porque continua sendo o de São Paulo. Mas tinha tudo para ultrapassar e passar por cima de tudo isso. Mas infelizmente se debandaram para outro lado. Coisas muito recentes que você está vendo. O último presidente, que inclusive eu votei, no Sindicato do ABC, o Luiz Marinho, hoje está como ministro do trabalho, fazendo as burradas que ele está fazendo lá. Eu fico assim, Guilherme, totalmente frustrado. Pra quem conhecia esses elementos, e ver as merdas que eles estão fazendo hoje, não dá para entender. Esse sistema que a gente vive é um sistema muito desgraçado. Me desculpe se fere seus princípios, mas eu não tenho outras palavras pra dizer a não ser essas: é um sistema que é um dos piores assassinos que a gente pode ter conhecido, não tem nada que mata mais do que isso, não. É muito complicado.

Então, Guilherme, basicamente, sem falar dos movimentos que a gente participou, de bairro, o movimento das "Diretas Já", “impeachment" do Collor, defesa da indústria nacional. Então, no geral, é uma trajetória que a gente conseguiu estar passando. Agora, existem coisas mais típicas da organização do local de trabalho, junto do sindicato. Mesmo contrariando alguns diretores de sindicato a gente conseguiu fazer na época grandes greves, greves de 42 dias. Existe uma infinidade de coisas que a gente pode estar falando. A minha trajetória basicamente, desde começar até chegar nessa coisa que está aí hoje... Agora tem coisas mais específicas que a gente pode estar lembrando e contando para você.

Queria que você falasse sobre o trabalho na fábrica. Como que era o trabalho? Que função você exercia? Como era a fábrica?

De que ano você quer saber isso aí? De 78? Qual ano mais ou menos? Você diz da fábrica que eu trabalhei, né?

Isso. Você trabalhou em mais de uma, né?

Não, eu trabalhei em uma só. Ela mudou de endereço e de dono várias vezes. Na época era de italianos. Hoje é uma multinacional. Mudou várias vezes, mas continuei no mesmo lugar. Basicamente qual ano você está querendo saber? Porque mudou... em 76 que eu comecei lá no $A B C$, era bem diferente do que é agora.

Nos anos que você trabalhava.

Trabalhei até ano passado.

Então na década de 70. No período antes da greve, até a greve.

Olha, não era nada muito fácil, não, viu Guilherme. A coisa era bem complicada. A fábrica, inclusive nesse esquema de ela ter mudado, e mudando gradativamente de São Paulo pro $A B C$, propiciou uma série de problemas lá. Tudo se justificava porque estava mudando. Tinha que ter paciência pra arrumar aquilo ali. Então a infra-estrutura era, principalmente nesse ano de 77, 78, na década de 70 propriamente dita, era super, super difícil. E basicamente não tinha CIPA, era forjada. Os homens que determinavam Fulano, Fulano e Sicrano, faziam uma ata, e esse pessoal que era "cipeiro". Dentro da fábrica a situação era 
terrível. Questão de higiene, segurança, alimentação. Quando a gente começou a restaurante lá, já foi no final de 78. Tinha três padrões de comida: "lavajão" pro pessoal do chão de fábrica; uma mais ou menos, que aí você não precisava passar na fila pra pegar o bandejão, já tinha uma sala separada pro pessoal de supervisão, e eles mesmos se serviam lá, a comida era um pouco melhor; e, pra diretoria já era a cozinha própria do local. Banheiro, não tinha bacia. A maioria das portas não tinha como você fechar por dentro. Papel higiênico não tinha. A água era água normal que vinha do poço. Poço artesiano. Vinha pra cá, pra torneira, não tinha filtro, muito menos geladeira. Estou falando da década de 70. Depois lógico que mudou. Além disso aí, as máquinas em péssimas condições de uso. A maioria dos funcionários que entravam eram analfabetos. Chegavam de tantos cantos do país. Pintou emprego, eles entravam. Não tinha nem muito negócio de ficha, ou coisa nenhuma. Não tinha exame médico pra começar a trabalhar. Entrou, no meio do dia já produzia. Quem produzia bem, ia ficando. Não produzia, já era. Era mais ou menos nesse aspecto. Perseguição da chefia era muito grande, super elevada. Era na base do chicote mesmo. Aí surgiu um tal de cronometrar o tempo da máquina, o tanto de tempo que o operário gastava pra fazer uma operação em uma máquina. Porque eles montam esses esquemas assim: eu gasto tanto tempo aqui, então a máquina seguinte, se gastar o dobro de tempo, preciso instalar duas máquinas, senão eu vou folgar quem está aqui atrás. E assim sucessivamente. Isso era marcado por um cara especializado, no caso, o cronometrista, pra fazer isso aí. Na medida que ele fazia essas varreduras todas aí, você já passava a ter a obrigação de produzir aquele tanto. Se você não produzisse você já era penalizado. O cara avisava uma vez, duas, e não era numa boa não. Era assim não base do empurrão mesmo. Ou vai ou racha. Não deu certo, trocava. Punha outro no lugar. Então era mais ou menos nessa base.

Ninguém tinha informação dos valores dessas peças, como eram vendidas, pra onde iam. Nem coisa nenhuma. As máquinas eram todas super ultrapassadas. Não tinha protetor, não tinha óculos pra proteção da vista. Luva, aquelas luvas de raspa, grandonas. Mais no sentido de proteger a peça que a própria mão. Então deu para a gente presenciar, infelizmente, algumas vezes, colegas terem o dedo decepado, mão decepada. Isso eu presenciei. Seu Antônio, que trabalhou junto comigo um longo tempo, no dia de sábado, depois do almoço, botou o pé no pedal da prensa, era uma prensa de corte. Ia correndo a fita de chapa de aço, e a prensa bateu direto. Você tinha que puxar, e pisar. Aí punha aquela fita e puxando. Já fica uma coisa automática. Ia puxando aquilo e a mão dele passava debaixo do estampo de corte. O pé dele fixo lá. Logo depois do almoço, não dá para saber exatamente o que aconteceu, se foi a comida que pesou, ou alguma coisa assim. Mas não tinha dispositivo de segurança nenhum. De repente [imita barulho da máquina] a munheca dele foi decepada. A mão dele caiu lá pro chão, dentro da luva. A gente já catou aquilo, já levou ele pro hospital. Depois esse aí já ficou alijado. Outro teve parte dos dedos decepados. Segurança lá era mais pra vigiar as pessoas, se estavam roubando alguma coisa, se estavam organizando alguma coisa, conversando sobre sindicato, ou alguma coisa assim. Segurança era mais pra fazer isso aí. Organizar fila na hora der vir embora, pra um não cortar na frente do outro, pra não sair sem marcar cartão. Inclusive os guardas na época eram armados. Hoje modernizou, naquela época não tinha esses negócio de chefe cumprimentar funcionário. Patrão passava de nariz empinado e não cumprimentava ninguém, não. Sujeira no chão era uma coisa demais. Eram péssimas as condições. Comida, você comia aquilo ali e não tinha 
nenhum direito de reclamar, não. Médico, eu já te disse: não tinha exame pra entrar ali, você imagina pra acompanhar. Se você saísse para ir no médico, você tinha que trazer o atestado e não podia ser médico particular. Tinha que ser médico da área pública, que também não era fácil você conseguir consulta. Então era mais ou menos nesses esquemas. Cesta básica não tinha. Vale-transporte não tinha. Um monte de coisas que a gente tem hoje, que não tinha naquela época, de jeito nenhum. E a jornada de trabalho naquela época você sabe, era 48 horas semanais, e você ainda era intimado a trabalhar depois dessa jornada, a fazer hora extra. Se você não fizesse, no decorrer do tempo você era substituído. Falavam que você não estava colaborando, que só via seu lado e não via o lado da firma. Então, assim não dava pra a continuar trabalhando lá. Além das perseguições que tinham, acontecia isto. E não tinha nessa época, na firma que eu trabalhei, participação do sindicato. Apesar de ter alguém que já estava contribuindo pro sindicato, mas não tinha participação ativa do sindicato como um todo. A discussão do sindicato pra valer começou a vigorar de 76 pra cá. Agora não posso negar pra você de forma nenhuma que quando se organizou o sindicato, o povo tomou consciência e essas coisas foram mudando gradativamente. A gente foi conquistando uma coisa, conquistando outra. Mas foi tudo assim na base da organização, e muitas vezes não dava pra negociar muito na conversa, não. Então a gente tinha que parar mesmo. Aí surgiu um monte de idéias, surgiram vários nomes de greve, a gente pode estar falando o nome delas, da época. Mas aí já pulando pra década de 80. Porque na década de 70 você não podia nem fazer greve, porque senão o pau comia solto. Muito complicado esses troço. Quem trabalhou na fábrica naquela época, como eu trabalhei, e tantos outros companheiros, sofreu um bocado. $O$ trabalho naquela época, em relação a hoje... hoje está bem mais moderado. Muito embora o ritmo de produção hoje, tem que correr mais. Mas naquela época os riscos que você corria eram bem maiores. Você não tinha muito por onde correr, não. Então a coisa era mais ou menos por esses caminhos aí. Que eu me lembro... Uma coisa importante: da entrada das mulheres pra trabalhar. Pela aparência física, eram muito cobiçadas pelo pessoal que tinha cargo lá dentro. Sofriam cantadas uma em cima da outra. Muitas vezes elas tinham que sair com o chefe pra não perder o emprego. Isso foi coisa que eu presenciei várias, que eu já andei questionando. Às vezes até ela tinha namorado que trabalhava na mesma fábrica, e ele, pra não perder o emprego, ou ficava calado, vendo até a namorada dele ser perseguida, cantada, ou tinha que sair da firma. Tirar ela da firma, ou sair. Porque se ele entrava em conflito, dançavam os dois. Uma coisa bastante complicada mesmo. Nesses anos duros...

Mas eu peguei como lição também que isso, apesar do sofrimento que a gente teve, foi uma etapa que a gente conseguiu aprender também. Ninguém conhecia os direitos que tinham. Coberto por um monte de coisas, mas ninguém lia história, não existia esse negócio de constituição. Não tinha essa coisa toda. Era fechado. A gente começou a ter acesso a essas informações na década de 80. Na década de 70 era muito difícil você falar sobre isso aí. Então era bastante, bastante, bastante complicado mesmo. O recebimento do salário era efetuado bem próximo ao horário do almoço. Aí você tinha que ir na hora do almoço até o banco trocar seu cheque. Então você tinha que deixar de almoçar e enfrentar uma fila no banco, que não tinha banco dentro de firma, não. Firma pequena não tinha banco. E se chegasse atrasado no mínimo era descontado. Não queriam nem saber. Na década de 80 pra cá foi essa coisa, depois da organização dos trabalhadores, do sindicato, essas coisas foram 
mudando. Até me lembro, isso não foi na década de 70, já foi na década de 80, que já tinha avançado um pouco, nós conseguimos colocar bebedouro dentro da fábrica. Foi uma luta danada isso aí. Participei da CIPA na época e nós implantamos bebedouro dentro da fábrica, em alguns pontos. Não era gelada, só tinha uma linha de água, colocava um filtro. Só que esse filtro ficou velho, rapaz. No bebedouro, tinha dia que saía uma larvazinha na minha água. Isso me marcou muito pelo seguinte: os colegas meus foram tomar água, não sentiram isso na boca, o outro percebeu num copo... não era copo descartável como hoje em dia tem, naquela época cada um tinha seu copo. Acionou o botão pra tirar água, veio um monte de bichinho dentro da água. Como eu era da CIPA, ele veio reclamar isso pra mim. Levei essa reclamação pro gerente. O gerente ignorou isso. Foi lá, coletou, viu, mandou que eu levasse o caso para o presidente da empresa. Eu levei. Quando levei esse caso pro presidente, o falecido Leonel, ele disse o seguinte: "Você é um agitador. Você é dos barbudos. Isso você está inventando pra arrumar encrenca aqui dentro da fábrica. Eu vou pegar o meu copo..." ele tinha um armário na sala dele, tinha o copo dele, a secretária dele, garrafa de água mineral. Disse assim: "Eu vou pegar meu copo, vou mandar a Zezé, que é minha secretária, pegar amostra da água lá. Se não tiver, você vai pra rua”. Aí pegou o copo, e eu perguntei: "Aonde você vai coletar essa água?" Ele falou assim: "Você pode ir com ela". Eu fui. Chegou lá, quando ela acionou o botão, vieram mais ou menos uns cinco ou seis bichinhos dentro do copo. Nós trouxemos, ela mostrou pra ele. Ele falou: "Ah, ela é uma tonta. Você enrolou ela, e ela deixou você deixar cair isso aí dentro. Ela é uma tonta". Aí ele foi, mandou ela jogar aquela água fora, lavou o copo, e falou pra ela: "Agora você vai ficar e ela vai buscar água sozinha. Leva guardanapo, você coloca em cima do copo, que eu quero ver isso". Aí eu falei pra ele assim: "Olha, se ela for pegar água no mesmo bebedouro, tudo bem. Se não for... que eu não sei os demais bebedouros como estão. Três bebedouros eu sei que estão assim, os demais eu não sei". Ele falou: "Então faz o seguinte: fala pra ela o bebedouro que ela vai pegar". Eu falei: "Você pega no mesmo bebedouro que a gente pegou”. Ela foi, quando veio, estava com bastante bichinho novamente. Aí ele pegou o telefone, ligou pro engenheiro de manutenção, e falou pra ele: "Olha, você tem até à tarde pra trocar os filtros de todos os bebedouros, senão amanhã te boto no olho da rua”. [risos] Foi bem assim. Aí o engenheiro acionou o chefe da manutenção e os funcionários dele. Foram tirar. Como eu tinha amizade com o pessoal da manutenção, e eu tinha comentado isso com eles, então o Zé Batista falou assim pra mim: "Olha, Adão, quando eu tirar os filtros eu falo pra você como é que está. Com certeza, eu que vou mexer com essa parte aí”. Ele tirou o filtro e falou que estavam empesteados de lodo e larvas. E tinham dois bebedouros que alguém já tinha tirado o filtro que naqueles filtros não passava mais água. [risos] Então era mais ou menos esses esquemas, viu, rapaz. Com esse acontecimento, eu acabei não sendo mandado embira nesse dia, porque, foi constatado que realmente tinha. Então, acabou sobrando pro engenheiro de manutenção acionar o chefe do setor e todo mundo correr atrás. Mas não houve troca de tubulação, nem coisa nenhuma. Simplesmente trocaram os filtros, e os bichinhos eram barrados no filtro, e a gente continuou tomando água.

Então foram algumas coisinhas que a gente pôde estar presenciando. Em cima disso aí, que deu essa melhorada, a gente foi ganhando mais um pouco de força. Isso já depois que implantou os restaurantes, com três padrões de comida. Serviram uma comida podre pra gente. Asa de frango. E a asa de frango estava estragada. Estão tinha três horários de 
almoço. O pessoal do primeiro horário não reclamou nada. Do segundo horário, teve um que conseguiu escapar e falar pra mim [faz voz de cochicho]: "Adão, a carne de frango está podre”. Eu fui lá e parei a fila. Foi um fuzuê desgraçado, vieram os guardas da firma, quiseram me agredir, porque eu não podia fazer aquilo, que eu estava agitando. Veio o chefe de segurança, veio o chefe de recursos humanos, veio um dos diretores. "Não dá para servir esta carne. Está podre. Está azeda. Não dá pra comer de jeito nenhum”. O que eles fizeram? Eu falei: "Eu vou tomar as providências. Porque vocês estão fazendo o pessoal comer isso, meio mundo vai passar mal”. Liguei pra polícia. Alguém estava me seguindo, viu que eu liguei pra polícia. Eles recolheram imediatamente aquela carne, puseram num tambor, levaram lá pro terreno vazio no fundo da fábrica. E aí colocaram um outro tipo de carne, que estavam servindo no outro padrão de comida, eles trouxeram para aquela linha. Aí quando chegou a viatura: "O que é que está acontecendo?" Quem fez a recepção foi o chefe de recursos humanos, junto com o chefe da segurança. "Não, é que tem um cara aí que é agitador. Parou a fila, arrumou um fuzuê danado aí, isso, isso, isso...” Aí eu encostei, não teve como eu cortar a conversa, que eu estava... Porque eu tinha que ser envolvido na conversa. Encostei pra ouvir. "Quem chamou a polícia fui eu, não foram eles. Eles foram fazer a recepção, eu encostei pra saber realmente o que está acontecendo”. Aí o... eu não sei como é o nome do cara que comanda a viatura, estava lá, mas sempre tem um chefe ali. "Quem é o cara?" “Ah, é esse que encostou aí”. "Olha aqui”, meteu o dedo na minha cara, "eu vou lá ver essa carne. Se não estiver podre, você vai preso, e você vai passar uns dias conosco lá pra você ver o que é podre". Falei: "Vamos lá ver sim". Chegaram pra ver a carne. "E aí? Tem alguma coisa podre aqui?" "Não, aí não tem, não." "E agora? Vou ter que te algemar." "Não, senhor. A carne que estava podre aqui está em um tambor lá nos fundos". Porque a essas alturas do campeonato, um amigo meu, que presenciou... quando eu estava no telefone lá eles fizeram isso, um amigo meu, que presenciou, correu e me avisou: "Olha, recolheram a carne, botaram num tambor e mandaram o faxineiro levar lá embaixo". Aí, o policial já com a mão na arma, eles não sabem andar sem essa porcaria. "Onde é que está isso?" Eu falei: "Está naquele tambor lá embaixo”. O chefe de recursos humanos: "É mentira, isso não aconteceu, não”. Falei: "Aquele tambor que está lá, Sr. Moisés”. Aí o guarda: "Vou lá ver". Fui eu, o Moisés, o chefe da segurança, os funcionários e três policiais. Chegamos lá, quando tirou a tampa, veio um cheiro, rapaz! Falei: "A carne que estavam servindo é essa. Se você quiser perguntar pro pessoal que comeu antes, é isso que estavam servindo lá". Aí o policial: "É, realmente é ruim isso que está aqui". Aí, falou pro chefe de recursos humanos: "Manda trazer dois saquinhos de plástico". Trouxe, coletou a amostra, levou os saquinhos. Não se teve mais notícia disso. [risos] Ficou por isso mesmo.

E, depois disso aí, teve um outro problema, que foi bicho na salada. Uma salada de alface ruim, cheia de bicho. Aí fui acionado novamente pra ver isso aí para os colegas, a reação do recursos humanos foi imediata. Me chamou lá e falou: "Ó, está aqui sua carta de demissão sumária. Mais uma agitação que fizer, você vai para o olho da rua”. E eu não pude falar para ele para dar, senão dava. Eu estava gozando de estabilidade. Eu tinha mais um ano pela frente de estabilidade pela CIPA. Mas se eu falo assim "Dá!”, ele dava na hora. Eu pagava esse ano em casa, ficavam livre de mim lá, e pronto. Mas eu preferi ficar calado, porque eu entendi que, eu tinha capacidade de arrumar outro emprego, mas a minha existência lá dentro era muito importante. Até que viessem outras pessoas. E surgiu, através 
de formação nas entidades, táticas de como se organizar no local de trabalho, é onde eu tive um sucesso maior com os colegas. Porque tinha aquele pessoal que você ia conversando com um, conversando com outro, na hora de almoço, na hora de entrada e de saída, até que você começasse a conhecer. Um negócio legal também é que tinha um time de futebol, na época, e eu ia bater bola com o pessoal. E no boteco não dava pra coletar porque eu não era de freqüentar boteco, nunca gostei. Coletava mais nos finais de semana e em horário de almoço. Aí comecei a ver assim: mais ou menos umas cinco ou seis pessoas da fábrica passavam informação rápida, passavam informação de uma maneira que ninguém sabia quem é que falou para quem. Isso foi muito legal pra gente se organizar no local de trabalho. Mais na medida que a gente foi avançando pra tentar organizar, não esqueça que a indústria também foi dando curso um atrás do outro pro pessoal dela e preparando o pessoal pra perseguir a gente. Perseguir não da maneira igual a dos policiais. Fingir que era teu amigo, provocar discussões quanto à fábrica, pra você ir soltando pra depois eles já... Tinha gente exclusivamente para isso dentro da fábrica. Então até isso a gente teve que começar a aprender e viver, pra você não se prejudicar tanto. Eu, na greve de 1980, foi uma greve dessa fábrica, o bicho pegou feio. Parou todo mundo. No terceiro dia de paralisação... não pode ser ingênuo de dizer que todo mundo parou porque queria parar. Tinha aquele pessoal que queria entrar para trabalhar ainda, mesmo sabendo que estava sendo lesado de tanta coisa errada que tinha, mas já estava começando a ficar difícil. Naquela época não estava muito tranqüilo, mesmo porque se saísse de uma firma, para entrar em outra, com esse negócio de greve, já era difícil. Mas a gente conseguia montar um pessoalzinho em uma esquina e outro em outra pra controlar, impedir a entrada. Qualquer afirmação que uma greve, de qualquer fábrica, teve $100 \%$ de participação, sem ninguém acuar ninguém, eu desafio. Eu não conheço. Pelo menos das que eu participei não foram. Tinha época em que se conseguia muito, tipo 80\%, 85\%, no máximo 90\%. Mas no resto, você tinha que cercar mesmo. Cercar, desviar, conversar, desviar as pessoas, até ir embora. Senão dava uma voltinha por aí e entrava dentro da fábrica. Com isso os empresários foram se organizando. Já não começou a funcionar mais esse negócio de jogar bola e ir comentando, porque já tinha penetra no meio. Tinha o esquema de saber que o pessoal já ia tomar uma pinga em final de expediente, principalmente nos finais de semana. Mandavam nego pra lá, até pagando. O cara chegava e propunha estar pagando pinga pros outros. Quanto mais o cara bebia, mais ele cutucava pro cara ir soltando quem estava fazendo o quê dentro da fábrica. Na segunda-feira, você chegava na fábrica e eram três ou quatro que estavam dispensados sem saber porquê. Nessa greve pesada que estou te falando, da qual nasceu meu filho mais novo, meu filho fui conhecer com três dias de idade. Eu estava ajudando a coordenar essa greve. Então eu entendi que a situação era muito grave, mas muito grave mesmo... eu minto, não foi em 80, foi em 82. A de 80 foi outro caso. E como eu vi que muitas cabeças iam rodar, minha esposa foi para o hospital para dar a luz a esse filho mais novo. Eu falei: "Bom, lá no hospital, está sob os cuidados do médico, tudo beleza. E aqui na fábrica, vai rolar muita cabeça. Então se não tiver alguém com a cabeça no lugar para tentar negociar, e tentar evitar expressões erradas, evitar conversa torta no boteco, vai rolar muita cabeça”. Nesse processo de greve, eu fazia, vamos falar assim, uma reunião ampliada, não era nem uma assembléia, para tomar uma decisão para saber se ia continuar ou não na greve. Deu parecer favorável que ia continuar, que não tinha decisão nenhuma tomada ainda, a negociação não avançava, tava 
só cada vez travando mais. Aí, uma parte ia pra casa, outra parte ia pro boteco. E pros donos do boteco era uma grande felicidade. Vendiam que era uma beleza. Vendiam muito. E ali, o pessoal já ficava tomando uma, tomando outra, quando dava oito horas que vinha o pessoal administrativo, uma parte entrava, outra parte ia lá pro boteco provocar uma discussão, que era para levantar nomes de pessoas que estavam mais envolvidas no assunto, que era pra levar lá pra dentro. A gente tinha essa preocupação de estar orientando: "Gente, greve é coisa séria! Greve é um estado de guerra. Quando você está de greve, você tem que estar mais consciente que nunca. Quando você não tem que passar a noite toda na luta, tenta dormir, tenta descansar, e se alimentar, porque você está numa guerra, você não pode estar fraco, senão o cara te quebra mesmo. Agora, você vai beber? Você vai estar inconsciente, cara! Você não vai poder estar consciente nem dos atos que você pratica, você vai estar bêbado. Se você for pego pela polícia, além de agitador, você é um cachaceiro também. Bêbado, um incompetente. Vai acabar perdendo seus direitos todos. Vai entregando o ouro todo. Então, tudo que a gente faz, que está fazendo de mobilização aqui, vai por água abaixo, que você vai entregar de bandeja”. Mas a cabeça do pessoal é meio fraca, viu, meu? Principalmente o pessoal que gosta de um gole, toma uma, começa a bater papo, vem tomando outra, daqui a pouco começava a xingar chefe A, chefe B, diretor tal. Aí já começava dedar um cara, outro cara. Era terrível, o negócio não era fácil, não. Pra você tentar costurar nesse meio, não era muito fácil, não. Bastante complicado. Tinha aqueles companheiros mais ponta firme, aqueles companheiros que eram mais pé no chão. Encaravam com eu estou te falando. Quando tinha uma greve, você tem que ter uma consciência que você está como se fosse um cara que está com uma "metranca" na mão pra meter fogo a qualquer hora. Qual é sua arma? Você não tem nenhuma faca, nenhuma arma explosiva. É seu braço, sua força, sua cabeça, o convencimento. Tinha que usar desses artifícios. Nessa década aí ainda, qualquer artifício que você ia usar, nem que fosse pra sua defesa, era complicado. Você era preso, e apanhava, e se saísse vivo ainda era sorte. Tem alguns companheiros vivos aí ainda, mais velhos que a gente. Você vai ver que eles têm lesões deixadas pela polícia. Hoje estão usando aparelho no ouvido, porque sofreram, como se fala, operação tampão. Pá! Estoura. Outros têm problemas de lesão no corpo mesmo, de tanto levar borrachada. Além dos que morreram, que a gente não sabe. Você já ouviu falar naquele cemitério de Perus, a vala do Maluf? Alguns dos colegas nossos, que eram mapeados e pegos pelo chamado "Esquadrão da Morte". Era morte encomendada, isso aí. Coisa que a gente não viu, mas a gente sabe que isso acontecia, porque a gente sabia da atuação do companheiro, de repente desaparecia. Depois aparece a ossada, a gente já sabia o autor disso aí. Então era assim.

Todos os direitos que nós conquistamos com esses esquemas que estou te falando, não foi dado de graça. Foi na porrada, foi no grito, foi na paralisação, na mobilização, não foi fácil, não. Hoje você negocia até participação de lucro. Você nem sabia o que era lucro, hoje você faz discussão de participação de lucro, de resultados. Mas é fruto de lutas do passado. Isso está acontecendo de maneira sacana. Pelo fato de nossos representantes estarem no poder, levou o sindicato junto. O sindicato hoje negocia muito mais com o patrão do que com a gente. Pra eles estão muito mais a serviço do patrão que do próprio empregado. Isso eu estou falando do sindicato nosso, lá do ABC. De São Paulo tenho informação que é pior ainda. Dos outros setores não tenho tanta informação assim, não. 


\subsubsection{Parte 2}

Você lembra, na época, final dos anos 70 , quanto você ganhava? Como era o orçamento familiar?

Dá pra ter uma base, viu, Guilherme. Um salário, principalmente de 70 até 76, o salário, no meu caso, estava muito baixo. Ainda não tinha fixado nenhuma profissão. Foi um momento de mudança. Eu tinha terminado um curso, e trabalhava em linha de montagem. Achei que aquilo pra mim já tinha superado, todas as minhas expectativas já tinham chegado num limite. Falei: “Assim não dá mais pra continuar, preciso avançar”. Depois de uma hora fiz até umas propostas pra sair da empresa, eu tinha feito um curso, essa coisa toda. E daí que eu entrei em outro ramo. Continuando a ser metalúrgico, porém não exercendo aquela função no setor de montagem, que era uma coisa que poderia ser feita por pessoas que não tinham muita pretensão a seguir carreira como metalúrgico e avançar um pouco. Só que encontrei bastante dificuldade nisso. Fiz o curso de eletricista, instalador e manutenção na época. Analisei que meu salário estava super baixo. No setor que eu trabalhava, que era o setor de montagem, eu já estava no nível maior que tinha, como oficial. Pra eu avançar mais eu teria que mudar de cargo, e não teria esse espaço, e nem tinha interesse mesmo, porque cheguei à conclusão que na linha de montagem era um mero apertador de parafuso. Eu queria conhecer mais essa coisa todo. Então eu fiz algumas propostas à empresa pra sair. Não foi aceita nenhuma das propostas. Eu cheguei e pedi a conta. Não foi aceito. Eles prometeram melhorar as coisas pra mim. Eu fiquei dando um tempo. Foi onde fui transferido pra... estou falando da década de 70, no final de 75, eu saí daqui do Bosque da Saúde, que essa empresa a matriz era aqui, e fui pra... São Bernardo não, Diadema, quase na divisa de São Bernardo. Lá entrei num campo diferente. Fui aprender uma coisa totalmente diversa daquilo que tinha sido treinado, em linha de montagem. Nem era meu objetivo também, pois eu queria trabalhar naquilo que estudei, que era eletricista. Não foi possível, fui barrado. $O$ chefe da manutenção na época não aceitou. Eu cheguei até o engenheiro diretor da empresa, apresentei meu diploma de eletricista, me prontifiquei a fazer um teste, ele mandou que eu conversasse com esse chefe da manutenção, ele não me deu atenção, retornei a esse engenheiro, ele mesmo foi falar que esse chefe disse na época: "Olha, não pego peão daqui de dentro. Se tiver que pegar, eu pego de fora”. Pra mim foi bastante desagradável essa postura do cara, mas por outro lado eu aproveitei isso, sinceramente eu aproveitei. Porque como eu me senti muito chateado com essa postura dele, serviu pra mim de escola para não praticar esse ato com outras pessoas depois. Não deixou de ser uma aprendizagem. Foi uma coisa que me denegriu, mas não deixou de ser uma aprendizagem pra mim também, de não denegrir a imagem das pessoas humanas, um companheiro, um colega, pode classificar da maneira que queira. Um companheiro de categoria. Aí, esgotadas todas essas possibilidades, como a firma estava em fase de crescimento, construíram em Diadema, já tinha transferido o setor de estamparia, e estavam transferindo o setor de acabamento de superfície metálica 
para lá. Polimento, galvanização, essa coisa toda. Aí eu, num determinado dia, estava até bastante revoltado com aquela situação, eu cheguei para a diretora da empresa, de recursos humanos e falei: "D. Aparecida, não dá mais. Eu já pedi para ser dispensado, você não dispensou. Pedi um acordo, você não quis fazer. E estou pedindo minha conta”. Aí ela se assustou, não quis me dar a conta, pediu que fosse até a sala do presidente da empresa, onde eu coloquei toda essa problemática pra ele. Ele falou: "Pode deixar que eu vou resolver esse problema pra você. Me dá um prazo de uns quinze dias". Aí passada uma semana ele me chamou e falou: "Você topa ir pra Diadema?" "Topo, sou um cara novo, preciso trabalhar". Naquela época já tinha casado, já tinha a primeira filha, pagava aluguel ainda, salário bem baixo. Eu nem entrei em mérito de salário com ele. Falei: "Topo sim. Se é pra mudar de área, pra melhorar, eu topo sim”. Fui pra lá e ele quis me dar um monte de setores pra coordenar. Eu já disse logo de cara pra ele: "Olha, eu não conheço nenhum desses setores que o senhor está jogando pra eu coordenar o trabalho. Eu não conheço esses setores. Primeiro preciso conhecer. Vou até sugerir para o senhor que a gente fosse por etapas. Em vez de eu pegar polimento, pintura e galvanoplastia, eu não vou dar conta. Eu não posso assumir uma responsabilidade que eu não está no meu poder, que sai do meu controle. Eu não consigo. Como é que eu falo pro senhor que eu vou fazer, sendo que eu não conheço? Então eu vou estar mentindo, e eu não gosto de mentira". Ele falou: "Então faz o seguinte: eu vou tirar polimento e você fica com o setor de galvanoplastia e pintura”. Eu falei: "Não, vou ficar com um só. Um desses três. Nada impede que no decorrer do tempo a gente possa estar avançando para outras áreas. Mas nesse momento, eu vou ficar com uma porque eu vou conhecer esse um. Aí você vai ver se o meu serviço está atendendo à sua necessidade, e a partir daí a gente conversa sobre outras áreas". E assim foi, eu fui pra lá. Eu entendi que era mais um desafio para mim nessa época. Correr atrás, fui. Peguei a área de galvanoplastia. Era uma máquina que ela sozinha fazia o serviço de 42 pessoas. A princípio a gente pode achar super ignorância isso. Aí depois eu fui ver que isso não era tão ignorante assim, porque essas 42 pessoas estariam sendo contaminadas com produtos bravos, altamente tóxicos. Cianeto, soda, ácido muriático, ácido nítrico, e tantos outros sulfatos. E com o sistema automático, duas pessoas que abasteciam essa máquina. Um colocava a peça e o outro tirava, ele não tinha o contato direto com esses produtos. Nessa parte foi vantajoso. A idéia era substituir.

Com seis meses, Guilherme, eu consegui dominar esse setor. Aí eu já tirava de letra isso aí. Não só de coordenar o serviço, deixar tudo em dia, construí amizade com todo mundo ali, e já consegui dominar até o controle químico desses produtos. Tinha um químico, que ainda estava na unidade de São Paulo, ele ia duas vezes por semana lá, e ele me dava as coordenadas. Eu mesmo analisava isso, passava por telefone pra ele, e ele já me dava as coordenadas de correção, e a coisa foi que chegou até um ponto que ele falou: "Olha, a partir dessa semana, você não precisa mais telefonar pra mim. Você pode fazer as análises, pode fazer os cálculos, e pode colocar que eu vou deixar um memorando pra empresa autorizando você a assinar a solicitação desses produtos. E eu como químico sou quem tiro esses produtos, respondo tecnicamente por isso. E vou passar essa responsabilidade pra você, que você provou que é capaz”. Então a partir daí, é que eu voltei a correr atrás do salário. Estava passando uma necessidade danada. Só que nesse intervalo eu também fiz um curso no SENAI aqui do Brás, que era só pra profissionais, ou seja, quem trabalha na área e 
quem estudou aquele assunto. Então eu fiz um curso de técnico em galvanoplastia, e a única pessoa com baixo nível de cultura, sem escolaridade que estava lá nessa equipe, era eu. Tinha pessoas de Sorocaba, tinha pessoas de Campinas, e de várias cidades aqui de São Paulo fazendo esse curso juntos. Correndo atrás de estudar, com apostilas, e prestando atenção nas palestras, e sendo até auxiliado pelo químico, que era professor de química também. As dúvidas eu reportava a ele, que me explicava. O nome dele é Osíris. Chamar o cara de químico; químico é uma profissão, ele tem um nome. Osíris Rezende. Eu não sei se ele está vivo ainda. É até uma falha em não tê-lo procurado, porque ele tem uma grande significativa na minha vida, esse cara aí. Me ensinou muita coisa.

A partir daí então, quando eu voltei, vou falar da briga do salário. O salário estava tão baixo, foi até na época que eu comprei esse terreno aqui, onde está a casa que a gente mora. Você imagina: uma mulher, uma filha, a filha meio doente, o salário baixo, pagando prestação e aluguel. A coisa estava pegando feia mesmo pro meu lado. Falei: "Bom, tenho que brigar com esses caras pelo salário. Não tem jeito”. E eu tinha informação que o serviço que eu estava executando, tinha que ter pelo menos umas cinco vezes mais o salário que eu estava recebendo. Falei pro chefe, ele me enrolou. Falei pro gerente, e ele me enrolou também. E essas enrolações aí, de um chefe, pro gerente, até eu chegar no gerente da empresa, isso rolou quatro meses. Isso porque eu acelerei o processo, senão ia demorar mais. Eu sei que quando o supervisor me enrolou, o gerente me enrolou, fez promessas e não cumpriu, eu tomei a iniciativa. Porque pra mim não tinha nem mais sentido continuar. Apesar de eu já ter passado por linha de montagem, ter feito curso de eletricista, já ter aprendido a coordenar o trabalho desse setor de galvanoplastia, e até a área química a gente fazia, falei: "Não dá mais. Está muito baixo o salário. Ou eles vão acertar meu salário, ou eu vou ter que partir pra outra”. Até recebi uma oferta de emprego para ganhar três vezes mais o que estava recebendo lá. Aí cheguei no presidente da empresa. O posto dele era aqui em São Paulo ainda. Ele ia duas vezes por semana lá. Pedi para falar com ele e ele atendeu. Como ele estava por dentro de todo meu assunto, de minha transferência, foi ele que me convenceu a ir pra lá, coloquei pra ele: "Sr. Leonel, estou executando um serviço técnico com salário de ajudante. Eu não exigi nada do senhor antes porque eu estava em fase de aprender, como o senhor me ofereceu três setores, eu falei 'Não. Vou ficar com um, porque eu não conheço.' Então o senhor sabe que eu sou uma pessoa que não gosta de enrolar ninguém, mas por outro lado eu não gosto de ser enrolado. Então hoje vim falar com o senhor, até reconheço que estou pulando etapas, que não seria o certo vir falar com o senhor. Eu teria que me reportar a outras pessoas antes do senhor. Eu já fiz isso e fui enrolado. $O \mathrm{Sr}$. Nito, que é o chefe geral" - o nome dele é Osvlado, mas todo mundo conhece ele por Nito "ele prometeu, e não cumpriu. O seu irmão, que é o diretor, também prometeu pra mim, e nada. E agora vim falar com o senhor, que eu sei que o senhor é o que manda tudo aqui. $O$ senhor é o presidente, o que o senhor falar pra mim, eu vou acreditar. Como eu nunca menti pro senhor, eu não vou dar o direito de o senhor mentir pra mim". Foi bem assim, Guilherme. Fui bem taxativo com o cara. Eu sempre gostei de trabalhar com essa linha. E naquele momento pra mim ali, se ele falasse "Você está dispensado agora", pra mim era uma boa, porque eu já tinha até oferta de emprego. Meu objetivo era até trabalhar na minha profissão, que eu já tinha estudado, e eu queria me aprofundar mais. Fui impedido por aquele chefe que eu tinha citado há uns minutos atrás, que recusou. Ele pegou e falou assim 
pra mim: “Adão, sabe porque você está...", ele nem falou recebendo, porque eles não usam o termo receber, eles usam o termo ganhar, "Você saber porque você está ganhado só isso até agora?" Falei: "Olha, Sr. Leonel, eu não sei o porquê, mas estou muito aborrecido, porque não está dando mais pra manter minhas despesas, não". Ele falou: "Porque você quer. Se você já tivesse me procurada há mais tempo, eu já teria resolvido seu problema”. Falei: "Não, Sr. Leonel. O senhor vai me desculpar, mas aí o senhor está pisando nas autoridades que o senhor tem aqui, que são o chefe geral e o diretor, que é seu irmão. Eu não falei que tive que passar por eles primeiro para depois vir aqui? Disse que estou reconhecendo o erro. Tenho que negociar com eles. Eles têm que negociar com o senhor". Eu não sei qual foi a jogada dele, Guilherme, mas ele disse o seguinte: "Pra mim, ninguém falou nada até hoje". Acho que é sacanagem do cara. Acho que ele sabia, sim. Mas aí eu falei: "Ó, Sr. Leonel, o que o senhor decidir, pra mim, está decidido. Só que eu gostaria dessa decisão hoje. Eu queria sair da sua sala já com a decisão tomada. Se o senhor acha que eu sirvo pra continuar trabalhando na sua empresa, pelo que eu já mostrei pro senhor até agora, o senhor veja o que pode fazer. Se o senhor pode melhorar meu salário ou não. Se o senhor acha que a gente não responde às suas necessidades dentro da empresa, o senhor fica à vontade. Meu cargo está à disposição. Que aliás, eu estou exercendo o cargo, mas não tenho salário”. Foi onde ele voltou a repetir: "Você está ganhando só isso até hoje porque você quer. Se você tivesse falado comigo, a gente já teria resolvido". "Isso quer dizer que o senhor vai arrumar meu salário?" "Vou” Isso era mais ou menos dia... foi pouco depois do pagamento. O pagamento naquela época era a cada dia dez de cada mês. Isso foi em torno do dia doze, de um determinado mês, que eu não me lembro o mês certo agora. Ele pegou e disse assim pra mim: "Olha, eu não vou falar qual o valor que você vai ganhar". Eles não falavam "receber", mas sim "ganhar". "Mas, no seu vale, do dia 25, já vai vir. Se não vier, eu vou continuar vindo aqui duas vezes por semana, você vem direto nessa mesa, porque eu vou tirar do meu bolso e te pagar. Tá bom assim?" Eu falei: “Tá ótimo”. Também nem perguntei quanto que era. Eu estava calculando que fosse em torno de uns $30 \%$, por aí. Já aliviava um pouco. Aí quando chegou no dia 20, meu salário veio mais que o dobro. Poderia dizer que seu eu estivesse ganhando 100, veio 250. Foi um aumento que nunca tive, foi uma coisa inédita. Quando eu saí da sala dele, o chefe geral perguntou: "Você estava aonde?". Eu falei: "Eu estava falando com o Sr. Leonel, presidente da empresa”. Ele falou: "Você é louco, rapaz! Você é burro! Você não pode fazer uma coisa dessas. Você tem que falar é comigo, ou então com o Sr. Valdomiro, que é o diretor industrial”. Falei: "Não, Sr. Nito. Quantas vezes eu já falei com o senhor? O senhor não me achava com cara de moleque? Quantas vezes eu já falei com o senhor? O senhor não resolveu coisa nenhuma. Falei com o Sr. Valdomiro, que é o diretor industrial, ele fez a mesma coisa que o senhor fez: nada. Agora falei com o dono", soltei um vocabulário meio pesado, "falei com o dono dos porcos, que é o Sr. Leonel, e ele me garantiu que vai resolver o problema”. "Ele vai te mandar embora, rapaz. Tomara que mande pra você deixar de ser burro, porque você não pode pular por cima dos outros assim". Falei: "Olha, pra mim tanto faz como fez. Se o senhor falar pra mim que seis ou meia dúzia, pra mim é a mesma coisa. Não estou ligando. Só que tem uma coisa, Sr. Nito. Sou um homem, tenho vergonha, vou continuar meu ritmo de trabalho, até a hora que eu for dispensado. Agora se o senhor achar que pode quebrar o [inaudível] pra mim, fica à vontade. Vai lá e 
fala pra ele que o senhor não quer, e o senhor me manda embora. $O$ senhor tem poderes pra isso”. Mas ele nem resposta deu, ele saiu.

Quando chegou no dia 25 veio, como eu disse pra você, foi um aumento bem acima do que eu esperava. Aí eu peguei o holerite, que chamávamos de envelope na época, não comentei nada com esse supervisor e nem com o diretor. Esperei o dia seguinte, esse diretorpresidente veio, e eu fui até a sala dele novamente e falei: "Sr. Leonel, obrigado pelo que o senhor fez, agora vou continuar fazendo meu trabalho como sempre fiz. O senhor não vai ter decepção. Pelo menos o senhor provou pra mim sua autoridade, e a exerce na hora que o senhor pode. Devo adiantar para o senhor que o seu irmão e o chefe geral estão colocando obstáculos, e eu não gostaria de estar criando conflito com ninguém". Ele falou: "Pode deixar que eu vou conversar com eles”. E assim ficou. Quando eu saí de lá, o chefe geral já me veio perguntar novamente o que eu fui fazer lá. Eu falei: "Fui agradecê-lo, que ele me arrumou o aumento que você não me arrumou”. "Como, arrumou?" E peguei e mostrei pra ele: "Olha aqui o holerite. Vai ver o que eu ganhava, recebia antes. E olha o que eu recebo hoje”. Ele falou: "Mas nem eu estou acreditando nisso. Esse cara é doido!". Falei: "Bom, se ele é doido ou não é, a firma é dele, e ele achou que tinha que fazer isso". Foi aí, Guilherme, que então eu dei uma melhorada no meu salário, e a partir daí não tive mais promoções. Foi promoção brutal que eu tive, foi essa. Só que nisso aí meu salário pulou, o dos outros colegas de trabalho que exerceram a mesma função que eu, em outros departamentos. Sem comentar nada, eles acabaram descobrindo isso aí depois, e gerou polêmica. Arrumaram um bafafá danado, eles vinham perguntar pra mim, e usavam o mesmo linguajar: quanto que eu ganhava. Eu dizia: "Eu não ganho nada. Eu recebo tanto pelo meu trabalho". "Mas não pode. Por quêe? É a mesma função. Vamos reclamar!" "É um direito seu”. E muitas vezes eu comecei a falar: "Ó, eu não vou dizer pra vocês quanto que eu recebo, porque isso diz respeito à minha pessoa, porque você não vai interar o que falta, e nem eu vou te dar o excedente. Cada caso é cada caso". E ficou assim. E a partir daí então eu não tive mais promoções. Tive só os aumentos de lei, e meu salário continuou sempre na frente dos demais que tinham a mesma função que eu, que no caso era supervisor. Eu fui promovido a supervisor. Aquela faixa de salário só poderia ganhar quem era supervisor. Com isso aí deu pra estabilizar um pouco a minha parte econômica. Quem está acostumado a administrar com 100, passa a administrar com 250, é bem mais fácil. Foi o que aconteceu comigo, e foi assim, essa questão. As dificuldades familiares: já tinha a primeira filha, depois veio a segunda filha. E aí eu também já fui começando a puxar minha família pra casa. Foi mais ou menos... mais ou menos, não. Fui isso realmente o que aconteceu. Quando veio essa promoção, isso arrastou até o último dia que eu tive dentro da empresa. Sempre tinha gente falando pelas esquinas porque eu tinha que ganhar mais do que eles, se eu exercia a mesma função. Foi até o dia que eu saí da empresa. Aquilo que eu te disse, cada um sabe o que está fazendo. Não sei se consegui responder o que você está querendo saber...

Claro que sim. Ainda sobre esta época, você freqüentava alguma igreja ou praticava alguma religião?

Olha, Guilherme, nessa época foi que eu comecei a... eu sempre fui, por tradição de família, participante da igreja católica. Mas sabe o católico “misseiro”, que vai à missa aos domingos? Sempre que podia, eu ia à missa aos domingos. Segui a doutrina que meus pais 
passaram pra mim, que foi a questão de aprender a fazer essas rezas... Sei lá, hoje a gente já tem outra concepção, fica até difícil a gente estar falando isso. Mas todo mundo tinha que aprender a fazer o sinal da cruz, rezar a Ave-Maria, o Pai Nosso, umas outras orações que eles ensinam. Fiz a primeira comunhão, fiz o crisma.

Mas eu vim participar de igreja mesmo, assim: deixei de ser "misseiro" e comecei a participar de discussões dentro da igreja. Foi a partir de 75 já comecei a participar disso, desses assuntos. Foi de uma organização que tinha o nome, na época... Eu trabalhei em alguns setores da igreja. Eu comecei a ter essas formações na chamada... um grupo que tinha, é um grupo muito importante no meu ponto de vista: ACO, que é Ação Católica Operária. Nisso eu aprendi muita coisa. Aprendi bastante mesmo! Foi essa questão de algumas palestras que a gente ia aos domingos. Aí já não era dentro da igreja, já era numa associação, mas o mesmo padre que celebrava a missa, tinha uma cabeça muito arejada. Um italiano. Eram um italiano e um francês. Esse italiano, inclusive, está na Itália agora. A família dele foi pra lá. E esse francês está aqui no Brasil ainda. Costumo encontrar com ele duas ou três vezes por mês, eles têm reunião juntos por aí, fazemos trabalho juntos. E a gente foi [inaudível] muito o nome dessas pessoas. O italiano, que na época era o Padre Virgínio, que depois deixou o sacerdócio, que ele entrou em conflito com alguma coisa da igreja, e achou melhor deixar de rezar a missa. Mesmo na época que ele era padre, ele não aceitava esse negócio da comunidade ter que sustentá-lo. Ele celebrava aos domingos, e trabalhava como mecânico numa fábrica. $O$ chefe dele, um bispo, não gostou, na época, e começou a pressioná-lo. Ele achou melhor sair, deixar o... não sei como que é o nome... presbítero, ou alguma coisa assim. Ele deixou de ser, e foi exercer como cidadão comum. Mas mesmo assim sofrendo as conseqüências da hierarquia, porque, uma vez consagrado padre, eles não abriam mão de ele ser um cidadão comum. Até hoje ele não pôde legalizar a situação dele com sua companheira perante a Igreja Católica. Ele não pôde casar, a Igreja Católica vivia dizendo a ele que ele já havia recebido o sacramento [inaudível]. Pros tradicionais isso pesa muito. A gente não quis nem saber disso aí. $O$ importante é que ele vive bem com a companheira dele e com a filha dele. Mas essa foi uma das pessoas que mais colaborou, que começou a mostrar pra gente como que funcionava a mais-valia. A questão da força de trabalho versus capital. Sei que ele fazia o convite a muitas pessoas. Isso normalmente acontecia aos domingos, às três ou quatro horas da tarde, mas já não era no salão da igreja, era numa associação de bairro. Na igreja não tinha essas aberturas, não. Eles não deixavam fazer. Os padres reconheciam isso pra associação. Então eles traziam várias pessoas para dar o curso. Traziam economista, traziam algumas pessoas bem interadas do assunto. E davam essas palestras pra gente, e iam mostrando pra gente como é que funcionava essa questão. A partir daí ele mostrou pra gente como é que funcionava a sociedade, como a sociedade estava dividida entre uma classe dominada e uma classe dominante. Isso foi muito importante. Fez com que no decorrer do tempo a gente fosse descobrindo uma coisa aqui e outra coisa ali, as falcatruas ideológicas, que surgiam propriamente dentro da igreja, com seu rebanho todo. Ensinou muito pra gente. Portanto, até hoje, não me desvinculei da igreja católica. Não por ser simpático às práticas dela. É uma instituição muito poderosa, mas manipula o ser humano, quer que ele fique com a cabeça bem assim, não enxergando nada, que seja aquele misseiro dizimista. Isso aí não faz o meu tipo. Só que, atuando lá dentro, eu acabei assumindo o Grupo dos Vicentinos, não sei se você já ouviu falar nisso aí. É uma 
organização que se originou depois da segunda guerra mundial, lá na França, para pessoa seguir o exemplo do apóstolo Vicente de Paula, que vou chamar de São Vicente. Até se você pesquisar, você vai achar. No Brasil inteirinho tem essa organização. Essa organização não era reconhecida dentro da igreja. Mas ela foi tomando uma dimensão, crescendo tanto, que ela foi criada com o objetivo de cuidar das viúvas e dos órfãos da segunda guerra. Por isso a igreja condenou, porque achava que quem estava fazendo isso estava pecando, em apoiar os órfãos e as viúvas. Era pecado, porque de uma certa maneira estavam ligados às pessoas que morreram na guerra, que participaram da guerra. Como se a pessoa fosse pra guerra porque quer. Que bom se fosse, mas não é. E atuei por um bom tempo. Fui tesoureiro desse grupo por um bom tempo. Criei muitos mecanismos para sustentar isso dentro de uma igreja. Consegui trazer isso mais pra próximo da igreja, e como tinha mais amizade com os padres, e depois que esse padre francês, e esse padre italiano foram afastados da comunidade, vieram outros padres, e a gente começou a ter amizade com eles, a conversar, a falar da importância disso. Até que chegou a um determinado ponto que a própria hierarquia da igreja reconheceu esse fragmento vinculado às bases da igreja. Mesmo sem seu consentimento, tinha ganhado uma dimensão muito grande. Achou melhor trazê-los pra dentro pra prestar serviço. E eu estava dentro do grupo nessa época. Teve um grande evento que aconteceu no Estádio do Pacaembu. Lotaram vários ônibus. Aquilo acho que foi um ponto chave pra Igreja falar assim: "O rebanho é muito grande, não posso perder esse pessoal. Vou trazer pra cá”. [risos] E fizeram isso. Então trabalhei com isso aí. Depois, o padre me encheu o saco pra trabalhar dando curso preparatório para pais e padrinhos pra batizado. Aí comecei a ver tanta palhaçada nesse troço aí, Guilherme. Desculpa, não sei qual é seu credo, mas comecei a ver tanta palhaçada, que falei: "Puxa, meu grande objetivo aqui é convencer esse pessoal, os pais e os padrinhos, que eles não devem batizar uma criança. Deixar ele crescer e procurar o caminho dele". Por incrível que pareça, isso aconteceu. Tinha um casal lá, nessa época eram três encontros que a gente fazia, e conseguimos passar pra eles a responsabilidade de um cristão, e eles acabaram questionando tantas coisas que decidiram não batizar a criança. O padre ficou meio bravo comigo. [risos] Ele até chamou esse pessoal pra conversar, mas não teve como ele reverter o quadro, não. Eu nem sei... foi até lerdeza minha. Eu deveria ter acompanhado pra ver que rumo deu isso aí, se esse jovem já foi batizado hoje, se deixou de ser. Mas acho que foi importante naquele momento. Depois, essa instituição, que era a C.O., por imposição de um papa, deixou de ser, porque ela estava incomodando. Pra ela continuar, e ela já não era pequena, já tinha crescido, o papa impôs que tinha que ter um " $P$ " de pastoral. Então tirou a "ação", que era Ação Católica Operária, e colocou Pastoral Operária, que é a que está aí hoje. Junto com a C.O., tinha a J.O.C., que era Juventude Católica Operária, que também teve um papel fundamental. Basicamente, é essa a história de igreja. Nisso, antes do papa que antecedeu esses alemão que está aí agora, o Bento XVI, acho que foi o Papa João XXIII. Não, foi o João Paulo II. Entrou esse polonês lá. O papa antes dele, tinha deixado a gente fazer essa teologia da libertação, através desse grupo nosso, a gente conseguiu montar um curso de teologia da libertação. Vinham uns teólogos dar curso pra gente numa linha libertadora, colocando a história do Brasil, colocando a questão do getulismo, colocando a questão dos senhores feudais, as bandidagens que rolavam por debaixo dos panos. E a gente começou a aprender. Nisso, João Paulo II assumiu, com a morte do papa que o antecedeu. Só que quando ele 
assumiu, já era esse Bento XVI que dava as cartadas. Uma pessoa muito poderosa, um alemão muito filha da puta. Começou a dar as cartadas. Primeira coisa que ele fez, foi suspender o curso de teologia da libertação. Tirou. A gente já tinha até as datas marcadas, $e$ comunicamos por telefone: "Olha, não vai mais ter aquele curso". E naquela mesma semana que ele suspendeu, ele impôs três anos de silêncio pro Leonardo Boff, que é um teólogo, ficava no Vaticano. E foi proibido de dar entrevista pra qualquer meio de comunicação, de escrever... inclusive eu tenha a coleção de livros dele, intitulada por "Fé e Política". Muito bom! Tiver várias palestras com ele. Mas foi imposta a lei do silêncio pra ele. E por incrível que pareça, a gente consegue entrar em conflito nos lugares que a gente vai quando se vê essas coisas alienadas. Porque eu lembro que nos fizemos uma reunião, já que estamos falando de igreja, pra acabar de explicar essa parte, de tudo isso que a gente fez aqui. A gente teve um encontrão ao lado da Praça da Sé, ali num colégio grande que tem ali, não me lembro o nome. Tinha gente pra dedéu. O bispo regional, D. Antônio Sérgio de Queiroz, e o da Praça da Sé, era D. Décio... não me lembro, esse que hoje é cardeal de São Paulo, ele participou, mas nem sei por que região que era. Nesse dia do evento que a gente fez, foram algumas análises de conjuntura, mas na linha eclesial. Só que teve alguém da Pastoral Operária, que já tinha organizado, e acabou alavancando isso, e foi muito legal, porque nós conseguimos montar dois documentos. Um em protesto à atitude do papa em ter cortado a teologia da libertação. E o outro foi do autoritarismo de ele impor a lei do silêncio pro Leonardo Boff. A gente ficou muito indignado com isso. Então mandamos uma moção de repúdio com muitas assinaturas. Foi meio polêmico, o bispo teve que falar isso durante a fala dele. Foram dois documentos. Foi esse em repúdio às atitudes do papa, e junto dessa, a gente mandou pro mesmo papa uma cópia do documento em solidariedade ao Leonardo Boff, que dizia o seguinte: "Boff, por mais que tentem calar, sua voz está em nossos ouvidos". Isso foi muito legal. A gente nunca deixou de lembrar do Boff. Eles não revogaram, não voltaram atrás. Ele teve que cumprir os três anos de silêncio. Ele cumpriu, mas sempre a gente estava discutindo essa questão do Boff, sempre a gente mandava carta pra ele dizendo: "Por mais que calem sua boca, sua voz entra em nossos ouvidos".

Então de igreja, eu participo até hoje, uma vez ou outra. Ainda estou na Pastoral Operária, trabalhando com um grupo de operários. Essa Pastoral Operária hoje é vista como os "politiqueiros" da Igreja Católica. Nem um padre gosta da gente. Bom, tem algumas exceções, tem alguns padres que são simpáticos e até apóiam nosso trabalho. Não sei te dizer exatamente se é por coerência deles, ou se é medo do grupo. Mas, poderia dizer, de um grosso modo, que é um filho indesejado da Igreja Católica. Ela não gosta. Fazendo uma ressalva, que D. Paulo Evaristo foi um grande companheiro nosso, e continua sendo. Eu até tenho uma gravação que eu fiz com ele, no dia 30 de outubro de 2005, ao completar 35 anos da Pastoral Operária. Nessa comemoração dos 35 anos da Pastoral Operária, D. Paulo Evaristo foi nosso convidado de honra que foi expor bastante coisa para nós, já bastante debilitado. A gente teve que policiar um pouco, porque a gente conhece as delimitações do cara. Mas tem a gravação aí, e o cara é porreta até hoje. E junto dele trabalhava o D. Luciano, que morreu não tem nem um mês. A cúpula de Roma, vendo D. Luciano e D. Paulo, o trabalho que desenvolviam na linha de libertação e de conscientização, e o D. Luciano era secretário geral da Conferência Nacional dos Bispos do Brasil. Quem tem essa função, tem que viajar um monte de vezes durante um mês. Tem que ir a Brasília prestar contas não sei 
com quem, acho que com os embaixadores, e tem que ir a Roma prestar contas com os cardeais. O que eles fizeram? Tiraram ele daqui de São Paulo e mandaram lá pra cidade de Mariana em Minas Gerais, porque em Mariana, pra ter acesso a aeroporto, ele que fazia essas viagens, ia pra Brasília e pra Roma, não dá pra pensar que vai fazer isso de carro, tem que ser de avião. Então eles falaram: "Vamos colocar esse cara lá num lugar bem longe", isso foi uma avaliação que a gente teve, "numas estradas terríveis que tem naqueles meios lá todo montanhoso, que ele vai gastar o tempo todo dele na estrada, pra ir até o aeroporto e voltar, e não dá tempo pra ele fazer os conchavos dele e perturbar o silêncio de quem quer salvar os fiéis". Há quem diga que esperavam que acontecesse um acidente mais rápido com ele, para se ver livre dele. Isso é o que a gente ouviu falar, mas a gente não pode provar isso. E acabou acontecendo um fato estranho com ele nessa estrada, que há possibilidades muito grandes de ter sido um atentado, mas não foi divulgado. Ele se recuperou logo. Veio a falecer há uns 20 dias atrás, mês passado. Nós estamos em setembro, ele faleceu em agosto. Finalzinho de agosto, ou começo de setembro, não me lembro exatamente as datas. Faleceu aqui no Hospital das Clínicas, aqui em São Paulo, de câncer. Não sei qual parte do corpo ele pegou. Mas foi uma figura importantíssima. Após a morte dele os demagogos começaram a fazer elogios. Você sabe que nossa sociedade é cheia de construir herói morto. O cara está morto mesmo, pode virar herói, não tem problema. Até o padre lá daqueles cantos do Norte do país, veio fazer um curso aqui em são Paulo, e ele está fazendo um curso aqui em nossa comunidade, estava falando na celebração dele, logo no primeiro domingo depois da morte do D. Luciano. Ele falou: "Não se assustem vocês em ouvir que D. Luciano vai ser canonizado em pouco tempo pela prática que ele teve na igreja”. E aí ele até perguntou: “Tem alguém que já ouviu falar nesse bispo, conheceu ele?" Eu levantei minha mão e falei: "Eu conversei com ele duas vezes. Aqui em São Paulo conversei com ele num encontro que a gente teve”. Foram mais vezes, mas eu disse duas vezes. Contato direto com ele, só um papo eu e ele, foram duas vezes. Foi uma aqui em São Paulo e uma lá em Minas Gerais, lá bem no meio do sertão. Aí eu fiquei sabendo que esse cara... esse cara, Guilherme, foi tão porreta esse cara, que só lendo as histórias dele que a gente fica sabendo. O cara não aceitava acumular nada. Ele tinha dois pares de roupa, que era um pra ele estar usando, e outro pra estar lavando. Quando alguém doava algo mais pra ele, ele dava pro primeiro pobre que ele via na frente. Quando alguém fazia doação em dinheiro, podia ser num envelope, ou qualquer coisa - há provas, presenciaram isso aí - que ele nem conferia. E se fosse da igreja, ele já passava logo pro tesoureiro. Agora se fosse pra pessoa dele, do jeito que ele recebia, ele já entregava pra um pobre na frente. Ele sempre se preocupou com a pobreza.

Então, de historia de igreja, basicamente é isso. Até hoje eu tenho que fazer esses enfrentamentos com os padres, porque mesmo não acreditando em nada do que a igreja prega, um monte de papagaiada, mais um atraso de vida do que tudo, mas eu não fujo de lá pelo seguinte: lá acumulam pessoas. E eu estando lá, eu tenho como policiar um pouco as falcatruas que são pregadas, e aquelas pessoas mais próximas, a gente conversa com eles, $e$ tenta mostrar pra eles que aquilo ali é um meio de arrecadar dinheiro também. Esquece esse negócio de pregar que você vai viver bem depois que morrer. Pô, isso é conversa pra boi dormir. A gente quer viver bem aqui, agora, já. Por isso que eu não abandono tudo: lá tem um aglomerado de gente que é manipulada, e eu sinto a importância de estar ali, até ter um certo jogo pra não ser expulso de lá, que você sabe que eles podem expulsar a gente fácil, 
fácil. Então por isso ainda me mantenho lá. Mas não é porque sou simpático a isso, não. Não quero criticar nenhuma religião, mas não vou dar aval a nenhuma. Pra mim todas são manipuladoras de idéias. Então, de igreja, resumidamente, seria isso que eu tenho pra te falar. A gente sofre com isso que a minha família é religiosa. Pra eles não faz mal; passa fome, se lasca todinho, mas depois morre e vai pro céu. É muito complicado.

Ainda sobre essa época, que jornais ou revistas você lia?

Olha, jornais, Guilherme, nessa época eu não lia jornal, praticamente. Eu lia alguns jornalzinhos de sindicato. Não é um jornal de grande circulação, é mais uma coisa de organização interna. Eu sempre procurava estar lendo esse tipo de coisa. Revista, a primeira revista que eu comecei a ler, foi uma revista entitulada "Sem Fronteiras", que eu nem sei se existe mais essa revista. Essa revista, as notícias dela eram muito voltadas para as injustiças praticada no sertão pelos grandes proprietários de terra, sempre ela mostrava os conflitos que tinha no campo. A Globo falava uma coisa, na revista chegava - não estou dizendo que era dona da verdade - mas ela mostrava com outra clareza, como que funcionavam os donos terra, e o pessoal do campo que trabalhava lá. O conflito dos índios, de grandes fazendas. Fui depois que eu comecei a ler mais os outros livros. Comecei a ler o livro "Fé e Política", do Leonardo Boff. Lia parte da Bíblia, achava ela bastante complicada também. Tem várias maneiras de ela ser interpretada. Se você não tomar cuidado, você pode ser manipulado por ela também. É um livro bom, não sei se você já leu. Eu andei lendo muitas partes dela, e consigo ver a Bíblia como o livro mais subversivo que tem. Por isso sempre tenho algum em casa e quando julgo necessário leio. Mas na minha ótica, não na ótica que o padre prega, que o pastor prega: "Olha, Jesus disse isso aqui". É a história de um povo que viveu no passado, eu consigo ver assim. Eu a leio como se fosse a história de um povo que viveu em determinada época, porém não consigo acreditar em tudo aquilo ali, porque devido às traduções dela, cada um traduz e já dá uma modificada de acordo com seu ponto de vista. Mas consigo ver que é um livro bastante subversivo, que pena que ele não é lido como deve ser lido. Ele é lido, interpretado, passado pra alguém de uma maneira estúpida, no meu ponto de vista.

Depois eu comecei, mais recentemente, dos anos 80 pra cá, a ler um jornal muito filha da puta, que é o "Estadão", fiquei com ele um tempo. Depois cancelei, e peguei a "Folha". Depois, como pegava as revistas da classe operária, elaborada pelo sindicato e outras organizações, lia bastante coisa relacionada a trabalhadores e empregadores. Eu lia bastante coisa nessa parte. Sempre me empolguei muito em ler essas questões. E via necessidade também... falei: "Bom, eu sempre vivi minha vida toda em conflito com a direita, eu preciso conhecer um pouco desse pessoal". Aí peguei a revista "Veja”, e fui assinante dessa revista por muito tempo. Assinei durante muito tempo, e a lia, lia as partes que me interessavam, a cada semana tinha um cara que escreve lá, tinha aquelas páginas amarelas, que davam mais destaque. Você vê que eles colocam a capa da revista com pessoas que você imagina que nunca iriam chegar numa capa de revista, mas quando você olha e fala "fulano está na capa da Veja”, só que você não sabe o que estão escrevendo referente a ele lá dentro. Então comecei a ler e perceber isso, como esse pessoal é filha da puta. Eles manipulam tudo, e desgraçam a vida das pessoas mesmo. Isso aconteceu com várias lideranças que foram capa de revista. Eu li, e agora já tem uns dois anos que não assino mais a Veja, que acho que 
já conheci o que queria conhecer dela. E hoje continuo recebendo a Folha de São Paulo nos finais de semana. Sexta, sábado, domingo e segunda, pego os tópicos ali que me interessam, e o resto vai mais na prática mesmo. [risos]

Voltando ao trabalho na fábrica, como que era a rotina na fábrica? Que horas você entrava pra trabalhar? Saía a que horas? Quantos intervalos você tinha, de quanto tempo? O que você fazia nesses intervalos?

Isso aí seria em qual ano? Dentro da década de 70, ou mais pra cá um pouco?

Mais pra década de 70, no período que antecedeu às greves.

Então acho que vou fazer o seguinte, Guilherme. Vou te falar como eu tive meu primeiro registro em carteira em 17 de março de 1969, entrei nessa empresa, que mudou de nome várias vezes. Mudou de dono várias vezes, que era de uns donos descendentes de italianos, depois foi mudando, mudando, mudando e hoje é uma multinacional que na América Latina tem 4 ou 3 unidades. Em 69, em 17 de março de 69 comecei a trabalhar. Até foi um primo meu que me levou. Quando eu cheguei lá, já podia chegar e começar a trabalhar no mesmo dia. Não tinha muita exigência. Ainda mais que eu tinha um primo que me indicou. Embora os caras naquela época iam até na rodoviária buscar peão que vinha de fora. Como no meu caso que vim de Minas Gerais, pouca saúde. Acabei entrando lá. Na portaria, onde fica o guarda que toma conta dos cartões, eu comecei a ouvir aquele barulho de prensa, que era a primeira sessão, comecei a ouvir a aquele barulho: "Pein pein". Comecei a imaginar do lado de fora: "O cara deve ficar feito um louco ali. Pula pra um canto, pula pro outro. Como é que vai se defender no meio de tanta porrada que deve dar esse negócio. Isso é barulho demais". Isso já preenchendo a ficha. Então isso foi um fator que me marcou muito. Veja bem, em 69. Me lembro como se fosse agora disso aí. Nisso aí, a gente se organizou pra começar a trabalhar, já deixou pronta a documentação toda, pra começar a trabalhar no dia seguinte. No dia seguinte já fui trabalhar, minha marmitinha com feijão com arroz já levei, quando eu coloquei ela na bandeja, que chamam de banho-maria, pra esquentar aquilo ali, eu falei: "Mas é tanta marmita aqui. Como é que vou achar a minha marmita depois?" Aí meu primo falou: "Não esquenta a cabeça, não. Na hora de comer, cada um sabe qual é a sua." "Mas como é que eu vou saber? Tem um monte de marmita igual à minha! Como é que eu vou saber? Não teria que colocar alguma coisa marcando ela, pra identificação?” Ele falou: "Não, não precisa. Até porque nós vamos sair pra almoçar um pouco mais tarde que os outros, então é fácil. Dá pra saber sim. E se na hora você estiver meio perdido, você abre. Você sabe o que pôs dentro dela, você sabe o que tem lá. Se não for a comida que você trouxe, não vai tirar". Aí fui lá pro trabalho. Aquela loucura toda, uma pressão desgraçada. E aí quando fui assinar o contrato de trabalho, a chefe de recursos humanos já trouxe o papel pra assinar. "Assina aqui, assina ali, assina aqui, assina ali”. Fui assinando. Nem sequer ela falava pra mim o horário de trabalho, nem qual era minha remuneração, e eu muito menos perguntei. No cartão de ponto já estava dizendo a hora de entrada, de almoço e de saída. A gente trabalhava naquela época 48 horas por semana. De segunda à quinta entrava às sete da manhã, horário normal. Entrava às sete, saía quinze pra meio-dia pra almoçar, e voltava à uma hora. Tinha uma hora e quinze de almoço, que era controle deles lá na época. Só que esses quinze minutos a mais que eu tinha de almoço, se estendia na parte da 
tarde. De segunda à quinta eu trabalhava das sete, com esse intervalo de almoço, e saía às quinze pras seis da tarde. Isso era no dia que saía, porque não saía. Normalmente você ia até quinze pras oito. Era basicamente obrigado a fazer duas horas extra por dia. Resumindo: entrava das sete horas da manhã e saía às oito horas da noite, quinze pras oito. Não tinha intervalo pra café. Nem de manhã, nem de tarde. Tinha o café. Cada um levava sua garrafinha, quando era ali pelas nove e meia mais ou menos, descia um guarda, com aquilo pendurado no braço, que eram vários setores, cada horário ele levava em um lugar. A gente já sabia, quando chegava lá já tinha o lugar onde você deixava sua garrafa. Ele enchia aquele caixote, você imagina um caixote de mais ou menos uns 60 centímetros de comprimento por uns 40 de largura, e com uma alça no meio. Ele enchia aquilo de garrafinhas e levava, já punha em cima de um caixote ou qualquer coisa, cada um vinha e pegava o seu e já ia trabalhar imediatamente. Não tinha esse lance de parar pra beber café, não. Ventilação: não tinha no setor. Super abafado. Desmaiava gente direto. Água: era água da rua. Acabava da rua, eles puxavam do poço. Vinha direto pra caixa. Não passava em sistema de filtro nenhum. Não tinha tratamento, não tinha coisa nenhum. Era temperatura ambiente. A temperatura que estivesse a água era a temperatura que você ia beber. Não tinha filtro, nem geladeira, nem porcaria nenhuma. Banheiro: eram quatro banheiros pra atender... Pra nós que éramos homens era mais fácil. Tinha quatro banheiros pra atender em torno de uns 25 homens. Aí um esperava um pouco o outro mijar, ou fazer outras necessidades, que eram só quatro. Não era bacia também, não. Você agachava lá e se virava. Papel higiênico, nem falar. Normalmente alguém levava algum papel que vinha embrulhando peça, ou qualquer coisa assim. O pessoal utilizava isso aí. Papelão, papel... mesmo assim os chefes ficavam de olho para não pegar os saquinhos que faziam embalagem. Não podia pegar, não, senão era desperdício. Jornal naquela época era coisa muito escassa, revista nem tinha. Então era um "Deus nos acuda" essa parte. Então as condições de trabalho nessa época eram essas. E nessa festa de assinar isso, assinar aquilo, sem saber de salário, sem saber de coisa nenhuma, quando terminou de assinar tudo lá, ela falou: "Daqui uns dias vai vir a carteirinha do sindicato para você. Você já assinou aqui a filiação ao sindicato”. Que era o sindicato do Joaquinzão, na época. Nem sei se já era o Joaquinzão. Era o Sindicato dos Metalúrgicos de São Paulo, que na época estava a serviço da indústria. Faziam com muita precisão esse negócio de consulta médica. Você ia lá, tinha consulta com o médico. Porque a firma não tinha convênio. INPS, naquela época não existia. Era um tal de "Sandu", depois foram mudando o nome. A coisa mais difícil que tem é unidade básica de saúde, não existia. A mais próxima da gente aqui era na Vila Mariana. Por aqui não tinha. Então tinha lá no sindicato um médico para te atender. Ele até dava atestado. A maioria dos remédios, que hoje o posto fornece, o sindicato fornecia. Como o sindicato conseguia isso eu não sei. Se comprava ou deixava de comprar, eu não sei. Sei que você adquiria. Colônia de férias tinha, porém a gente não usufruía, porque o cara fudido, com salarinho pequenininho, não recebia porcaria nenhuma, como vai pra colônia de férias? Votação naquela época também não tinha, votação para sindicato. Sei lá quem nomeava. Calculo eu que tinha alguém lá dentro que organizava isso. Aumento de salário era divulgado pelo governo uma vez por ano. Hora extra: lembra que eu estava te falando, que nosso horário de trabalho era até quinze pras seis de segunda a quinta, e sexta-feira era até às dezoito e trinta. E aí como você tinha que fazer mais duas horas extra, você ia até às oito e meia da noite. Sábado, a gente quase que 
não tinha sábado livre, a gente era convocado pra fazer hora extra todos os sábados. No sábado você entrava às sete e saía às quatro. Eles não pagavam almoço também nessa época, não. Você tinha que levar sua comidinha também. Não tinha vale transporte, não davam pra gente porcaria nenhuma. E percentual de hora extra em dia de semana era assim: em dia de semana eles pagavam dez por cento a mais que a hora normal. E aos sábados eles pagavam quinze por cento. Hoje mudou tudo isso aí. E no domingo que a gente ia eles pagavam vinte por cento. Não era cem por cento como é hoje, não. Então eram essas as condições. $O$ refeitório que a gente tinha lá eram umas mesas tudo atrapalhada, uns bancos grandes, assento coletivo, e se você se mexesse no banco todo mundo se mexia junto. Higiene, basicamente quase nenhuma. Quando eu comecei a trabalhar era desse jeito, e se alastrou por muito tempo. Depois vieram as mudanças, as coisas alterando. Aí foi melhorando o percentual que eles pagavam a hora extra. Importante: férias. Burrice desgraçada! Eu passei doze anos sem pegar umas férias ou descanso. Eles pagavam férias pra gente. Não tinha esse negócio de um terço a mais de férias. Nem aquela questão de você perder dez dias das férias, não. Eles pagavam lá pra gente e está certo. A gente não entendia porcaria nenhuma de lei. Davam o pagamento das férias, continuava trabalhando e você recebia o outro salário depois. Às você marcava cartão, às vezes não marcava, e recebia as férias trabalhadas, não tinha esse negócio de afastar. Era basicamente assim. Em relação a máquinas, eram das piores que você pode imaginar, os barulhos. Tinham as furadeiras elétricas, que poderia comparar hoje: sabe essas furadeiras manuais que a gente faz buraco em parede? Que o pessoal chama de "maquita" ou da marca Bosch. As parafusadeiras que tinha na época, tinha um barulho maior do que esse. E você trabalhava com aquilo no seu ouvido. Você apoiava ela aqui, pra apertar os parafusos. Isso aí já foi um avanço, porque antes era uma chave de fenda. Surgiu o parafuso Philips depois, não tinha aquela chave Philips. Era fenda mesmo. Com a chave de fenda, se você riscasse uma peça era uma bronca desgraçada, até suspensão levava. Sua mão, não interessa. Se fosse pro saco, não tinha problema, não. A peça não podia riscar, que era complicado. Depois veio essa furadeira que eu estou te falando, que zoava sua cabeça toda. E quando tinha que fixar uma peça na outra, que não fosse parafuso, chamava-se rebite. Tinham os furos que culminavam na fixação de uma peça na outra. Tinha uma máquina que chamava rebitadeira. Hoje isso não existe mais nesse modelo. É tudo pneumático, com ar comprimido. Naquela época, não. Era marretada mesmo. Girava a polia. Tinha um eixo epicêntrico, e você pisava com o dedão e aquilo lá: "prrrrrruum". Era um puta de um barulhão. Devia chegar a - hoje que a gente conhece esses palavrões: os decibéis - devia chegar a mais ou menos uns 140 decibéis. E não tinha limite de horas pra você trabalhar com esse barulho aí. Era o dia todo. Inclusive eu perdi a audição em vinte por cento, graças a essas condições de trabalho e à desinformação que eu tinha na época. Serviu como escola pra mim. Depois que eu fui tomando a consciência, já serviu pra trabalhar em cima disso depois. No início, Guilherme, a coisa era exatamente desse jeito que eu estou te falando. E de uma firma pra outra não tinha muita diferença. Batia papo com outras pessoas que trabalhavam em firmas do mesmo ramo. E o trabalho era o mesmo, quando não era pior ainda. Era muito complicada essa situação. Não se ouvia falar em direito, nem em porcaria nenhuma. Era super complicado. Só quem trabalhou nesses anos sabe o quanto o trabalhador se ferrou. Bom, continua se ferrando hoje. Modernizou um pouco, mas naquela época a coisa era bem cruel. A vantagem é que naquela época você tinha 
uma grande oferta de emprego. Tinha muita frente de trabalho. O peão chegava do sertão hoje, e se quisesse trabalhar hoje, trabalhava hoje mesmo. Mas era uma loucura. Transporte coletivo, meu Deus! Que merda que era aquilo. Não tinha metrô ainda. Os ônibus vinham da Praça João Mendes, faziam ali a Av. Jabaquara, caía na Bosque, e ia pegar a Av. do Cursino. Eu pegava ele, quando pegava. Quando pegava, pegava ele na Bosque, aí vinha, você imagina o ônibus, superlotou, já vinham uns pendurados na porta, depois já vinham uns quatro ou cinco pendurados uns nos outros. Ficava só pé ali, e ficava quase deitado pra não ir embora. Era esse esquema. Mas a maioria das vezes eu ia e voltava a pé. Onde eu estava morando era próximo daqui, até lá eram seis quilômetros e pouco de distância. A gente ia e voltava a pé. Não tinha só o fator da superlotação do ônibus, mas o fator econômico mesmo. O salário era tão baixo, que não podia mexer no dinheiro. Então, era basicamente assim essa parte que você me perguntou. Não sei se era basicamente isso aí, mas o que eu vivi foi isso. Não dá pra ficar jogando panfleto. Eu tenho que falar aquilo que eu vivi.

Quem eram seus companheiros de trabalho? Vocês se encontravam fora da fábrica pra outras atividades? Vocês conversavam dentro da fábrica?

Dentro da fábrica não dava pra conversar. De jeito nenhum. Tinham lá os encarregados e sub-encarregados. E tinha a questão do barulho. Pra você falar, era gritando um com o outro. Não tinha jeito. Porque era essa a questão: você tinha que fazer sua operação aqui, empurrar pro outro lá. Depois que surgiu a linha corrente, que era uma correia largona, que o motor girava aquilo e já tinha a faixa pra colocar as peças, você não podia pular as faixas. Mas antes de surgir isso, já foi um primeiro avanço. Era uma mesa de madeira grandona, aquela mesa compridona. Tinham as tomadas, tinhas as prensinhas, pra você fazer esse serviço de montagem, e tinham um que colocava a primeira peça, e ia passando um pro outro. Um fazia uma parte, outro fazia outra. Então, quem estava na ponta aqui, normalmente o chefe ficava mais ali. Porque aquele ia pondo a peça ali, aí chegava o [inaudível] pra fazer frente aqui. Ninguém podia amarrar. Não sei como é que eles conseguiam descobrir que essa operação era mais demorada que a outra ou não. Mas não podia acumular. Na medida que esse aqui pôs, aquele ali fez a operação dele, o máximo que poderia acumular eram duas peças. Mesmo assim você já levava bronca. Se fossem três peças então você estava sujeito até a suspensão. E ia até sair no final da linha. O pessoal do final da linha, tinha duas pessoas que a gente considerava que eram pessoas mais valiosas dentro da empresa. Uma fazia a inspeção final, e a outra fazia a embalagem. Além do trabalho delas ser mais suave, não exigia tanto esforço. E eram enquadradas como privilégio. Quem ia fazer aquilo ali não queria nem se misturar com as de cá, porque elas achavam que estavam mais como patrão que empregados. Só que sobrava bronca também. Se elas iam pro banheiro e sobravam peças pra elas inspecionar, chegava o inspetor, e quando elas vinham, chicote nelas. A de embalagem final era do mesmo jeito. Então isso não permitia que houvesse diálogo. A hora de almoço era aquela correria. Você tinha que disputar lugar pra sentar. Tinha pouco lugar no refeitório. Dividiam em vários horários de almoço. Inclusive eles não colocavam um setor junto com o outro. Pegava um setor e jogavam tudo lá. Acabou aquele setor, vinha e colocava outro. Então não dava pra você trocar muita idéia. Agora depois de uma jornada dessas, você não tinha muito mais o que conversar. Agora, existia sim. Por exemplo, no meu caso, eu tinha alguns conterrâneos, da mesma região que eu 
nasci, que arrumaram serviço nessa empresa. Então a gente sempre conversava. Sempre lamentava um com o outro, que estava com o dedo todo lascado por causa das borrachas duras, o outro por causa da chave de fenda. E o papo girava mais ou menos em torno disso aí. Não era muito diferente. Ou reclamando que já estava com saudade de pai e mãe, ou coisa parecida. Os papos giravam um pouco assim, mas ninguém discutia mais nada, não. Basicamente, não rolava muita amizade.

Com o decorrer do tempo, você já i a ficando um pouco mais esperto. Principalmente no meu caso, que tinha 19 anos quando entrei nessa empresa. Lá pelos meus 20 ou 21 anos, trabalhavam muitas meninas ali, já começavam as paquerinhas também. Aí já arrumava um jeito de almoçar rapidamente pra bater um papo com as garotas lá fora. E às vezes até dava certo de ir embora juntos. Mas eram aqueles papos, como se diz... muito restritos. Quando não se falava de serviço, você falava de namoro com a menina. A maioria o pai já estava na cola também. Meio complicada essa história aí. Então não tinha muito diálogo. Você não tinha muita diversão também. Não tinha basicamente diversão pra ninguém. Que eu lembre, não. Com o decorrer do tempo, começaram a arrumar um time de futebol. Aí foi quando a gente começou a ampliar a amizade, através do bate-bola que a gente fazia. Aí gerou uma polêmica desgraçada. O cara falava: "Não, eu não vou poder trabalhar esse domingo. Eu vou jogar bola". Teve uma época que eles até interferiram: "Se o pessoal continuar com essa postura de deixar de trabalhar pra jogar bola, não tem mais time”. Eles não davam nem um centavo pro time, e a gente ainda levava camisa com o nome da firma. Fazia propaganda da firma [risos]. Pra você ver como as coisas aconteciam.

O meu despertar da consciência crítica se deu nos papos que nós falamos há uns minutos atrás, naquelas palestras que a gente teve que eu fui ver que o peão era explorado, e continua sendo. Cada vez exploram de um jeito. Mas dentro da fábrica, naquela época, não tive condições de crescer coisa nenhuma. Foi depois dessa formação, que a gente passou por algumas palestras, por algumas formações, a gente começou a... como eu já te disse, mais dos anos 80 pra cá que a gente passou a conhecer a questão do capital versus trabalho, da organização no local de trabalho, e essa coisa toda foi mudando. Primeiro a gente começou a formar grupinho de amigos, e depois a gente até começou a saber como você vivia dentro da sociedade. Importante foi que nesses cursos, não os com os padres, mas já na Pastoral Operária, na linha da teologia da libertação, nós fizemos alguns trabalhos analisando como era o governo Jânio Quadros... desculpa, Jânio Quadros não, Getúlio Vargas. Que teve duas fases, a autoritária e a outra, dizem que popular [risos]. O pai dos pobres, a mãe dos ricos [risos]. Complicado esse carinha. E foi quando a gente começou a aprender como identificar quem era quem dentro da fábrica. Isso aí eu não aprendi dentro da fábrica, não. Isso aí eu aprendi nesses movimentos sociais conhecidos como extrema esquerda. Poderia te dizer, com bastante propriedade, que seria a oposição sindical. Tem hora que eu paro e penso: "Que bosta! O sindicato deveria ensinar isso pra gente”. Nós temos que fazer oposição ao sindicato pra conhecer isso. Foi aí que a gente começou a fazer esse reconhecimento de como se organizar na sociedade, principalmente dentro da fábrica.

Aí eu não sei se vou fugir um pouco do roteiro, da pergunta que você quer fazer, Guilherme, mas acho que é importante você saber disso. Nós aprendemos... eu não sei se hoje isso existe mais, mês que vem completa um ano que eu me desliguei da empresa. Inclusive eu deixei um grupo muito bom nessa empresa, com essa linha de formação que eu aprendi. Não 
só eu, mas várias pessoas aprenderam. Eu tive oportunidade de aprender e praticar, colocar em prática isso daí. Conseguia fazer mapeamento de fábrica. Por isso que eu te disse, que essa coisa que eu estou te falando não é matéria pra comércio. Eu jamais deixaria isso pro comércio, que se isso for pra ser comercializado, vai ferrar com a vida dos futuros trabalhadores. Se você publicar isso e alguém, ler, você vai estar colaborando para a classe exploradora aprimorar os conhecimentos deles e reprimir mais ${ }^{6}$. Então fica totalmente proibida a comercialização disso aí. Se um dia eu souber, eu te processo. Se eu estiver vivo ainda, eu te boto na cadeia [risos]. Minha proposta foi de fazer isso aí pra falar o que eu vivi. Isso interessa a você que está fazendo pesquisa, mas já deixo bem clara essa parte: pelo amor de Deus não vai vender isso, porque quem passou isso pra mim sofreu muito pra aprender, $e$ eu tive que lascar muito pra conhecer isso aí. Não foi em faculdade, que infelizmente eu não pude fazer.

A gente se organizou, a organização em local de trabalho, mais na linha de oposição sindical e patronal. Com o decorrer do tempo da convivência que você ia tendo ali, você conseguia identificar. A gente começou a qualificar: o dedo-duro, o boca-mole e o pontafirme. Você tinha esses três tipos de pessoa. A gente aprendeu algumas táticas. Por exemplo, se tinha uma notícia que você queria que corresse pela firma, mas que não aparecesse quem era o pai dessa conversa, você comentava com o dedo-duro, perto do boca-mole: "Poxa, eu estava no banheiro e ouvi uma pessoa falando assim, assim. Mas olha," falava pro dedoduro, “ isso aí é segredo absoluto. Não vai falar pra ninguém. Não vai dedar isso pra ninguém, que é complicado. Eu ouvi, não sei quem falou. Eu ouvi já no banheiro, ouvi em outro lugar também, o pessoal comentando". Mas você nunca citava que lugar que era isso daí. Essa era a estratégia pra você espalhar aquela notícia dentro da fábrica. Às vezes você não tinha ouvido falar porra nenhuma, era a primeira vez que falou, mas você dizia "ouvi alguém comentando isso". Aí o boca-mole, daí a pouco espalhava pra fábrica todinha. $O$ sucesso era você pedir segredo. Você dizia isso pro dedo-duro, mas perto do boca-mole. $O$ boca-mole espalhava pra fábrica todinha. Era impressionante como isso corre pra caramba. Agora, quando tinha uma estratégia que você tinha que montar pra desmontar a perseguição que os patrões faziam em cima da gente, tinha o trabalho de fazer esse mapeamento, de encontrar o ponta-firme em cada setor. Não adianta você ter dois ponta-firmes no mesmo setor. Podia até ter. Por falta de um, você conversava logo com os dois. Funcionava bem. Mas a principal estratégia da gente era essa: você ter esses tipos, essas figuras, em todo setor da fábrica. Esses três tipos de posição de pessoas, de comportamento de pessoas, melhor dizendo. Então o ponta-firme era aquele que você podia botar por dentro desses assuntos estratégicos, que você tinha que programar pra uma greve, pra uma discussão, ou esse tipo de coisa, você comentava com ele e ele já sabia como lidar com isso. Em determinadas situações, aquela pessoas que você podia contar. Então qualquer coisa de errado, de perseguição que acontecia naquele setor, você já sabia que tinha o ponta-firme observando aquilo. E sempre ele era o bobo. Todo mundo comprava ele por besta. "Esse aí é um bobo. Você pode falar o que quiser perto dele que ninguém sabe”. Mas o comportamento desse ponta firme aí, Guilherme, é super importante. O ponta-firme nunca subia em cima de um

\footnotetext{
${ }^{6}$ Em conversa posterior à entrevista, Adão autorizou a publicação desse trecho, alegando que esse conhecimento foi muito importante na época das greves, mas hoje já é bastante difundido.
} 
banquinho pra fazer discurso pra ninguém. Ele nunca pegava o microfone. Ele nunca se aproximava do representante do sindicato. Ele ficava na dele. Mas é o cara que estava por dentro de todo lance que acontecia. Isso é uma coisa que a gente aprendeu. Eu não sei se isso veio da Itália, de onde que veio. Eu sei que eu aprendi isso nos cursos que a gente andou fazendo de como funciona a sociedade. Foi muito bom isso aí. Eu fiz questão, mesmo pulando um pouco a sua pergunta, de frisar isso, que acho que é importante você saber disso aí. Você que está pesquisando essas coisas, é importante. A gente ia falar de outras épocas, mas são coisas que a gente aprendeu a fazer. E eu consegui fazer isso na fábrica que eu trabalhei esse tempo todo, e foi um sucesso incalculável. Foi um sucesso, que assim, pelo amor de Deus, foi muito bom, muito bom! E mesmo depois que eu saí da fábrica, agora vai fazer um ano que eu me desliguei, e eu ainda mantenho contato com essas pessoas. Muito secreto. Lógico que eu não vou telefonar pra eles lá dentro da firma, que você saber que existe um meio de eles gravarem. Então a gente tem o telefone um do outro, um conversa com o outro pelo telefone. Uma vez ou outra que a gente se encontra, essa coisa toda. Então é muito dez isso daí, é super legal. Então era basicamente isso, Guilherme. Eu pulei um pouco fora do seu roteiro...

Tudo bem.

Mas a gente volta a repetir, é importante estar falando essa experiência que eu vivi. Super importante.

\subsubsection{Parte 3}

Adão, você era filiado a algum sindicato?

Sim. Fui filiado ao sindicato aqui de São Paulo em março de 1969. E fiquei filiado a esse sindicato até 1976. Aí não é que eu deixei de ser filiado. Como fui transferido de São Paulo para o ABC, nessa mudança eu pedi minha transferência para o sindicato de São Bernardo. Então fui filiado ao sindicato, não lembro exatamente a data. Foi no mês de março de 1969. Até o ano de 2005 eu fiquei filiado ao sindicato, inclusive hoje ainda sou, mas não estou na ativa. Hoje ainda sou aquele sócio remido, ou alguma coisa assim. Passou um determinado tempo, você não precisa mais contribuir financeiramente, e passa a usufruir da... ou seja, tem direito a participar de uma reunião, porem não pode estar votando. Em alguns momentos, eu não vou poder estar votando. No caso da campanha salarial da categoria, eu não vou poder votar. Minha categoria agora é outra, sou aposentado. Inclusive, esse mês que vem vou estar me filiando ao Sindicato dos Metalúrgicos Aposentados, que a sigla é AMA. Fica basicamente junto do Sindicato dos Metalúrgicos do ABC, lá na R. João Bosco. Esse tempo todo a gente contribuiu com o sindicato, não só financeiramente, mas em outros pontos.

Como funcionava o sindicato na época? Mais especificamente o de São Bernardo? 
É o seguinte, Guilherme, o Sindicato de São Bernardo, como eu fui filiado... de 69 até 76, o sindicato era como aqui, o de São Paulo. Eles têm um número de representantes para assinar os acordos. O aumento era uma vez por ano, determinado pelo governo, não tinha discussão, não tinha coisa nenhuma. Era só pra legitimar essa coisa. A CIPA não existia, nem coisa nenhuma. De 76 pra cá eu comecei a participar mais ativamente, alguma coisa me chamou a atenção. Ao ir pra São Bernardo, pro ABC, que era o sindicato de São Bernardo, eu fui no final de 75, e minha transferência se deu em 76. Nas discussões que estavam acontecendo nos anos 70, quero crer que isso começou até um pouco antes de eu começar a participar. Me lembro que uma reunião que teve dentro da fábrica, que não foi com o sindicato, foi uma preocupação do diretor financeiro da empresa. Tinha gente que olhava pra tudo que estava acontecendo. O Lula, na época, trabalhava na Villares, e ele que começou a questionar essa questão do sindicato. Porque pagava aquele determinado valor, e a preocupação era oferecer algumas vantagens que seriam conquistadas por lei. A questão da assistência médica, e essa coisa toda, o sindicato daquela época se sentia muito bem em fazer isso. Fazer consulta pros seus filiados, já fazendo propaganda das colônias de férias na praia. Não tinha discussão nenhuma. Chegava na época dos reajustes de salário para repor a inflação, simplesmente eles assinavam sem falar nada pra ninguém. O Lula começou a questionar isso junto ao Djalma Bom, que era o presidente do sindicato, na época, em São Bernardo. Ele disse pro Djalma: "Djalma, esse sindicato veio de São Paulo pra cá, e ele tem esses objetivos, que não traz basicamente benefício nenhum pro trabalhador. Tira o dinheiro do trabalhador, e assina algo em nome do trabalhador. Sequer discute com o trabalhador se é isso que ele quer ou deixa de querer. Simplesmente se vê no direito de fazer isso, reajusta a mensalidade do jeito que acha melhor, e em contrapartida começa a oferecer substituição do serviço do INPS, que nós já pagamos, que seria pra dar essa assistência médica. O sindicato começa a fazer esse tipo de coisa. Então nós vamos tentar mudar um pouco essa realidade. Esse sindicato precisa estar a serviço do trabalhador, que hoje trabalha uma quantidade de horas muito elevada em relação a outros países, sem segurança nenhuma, com muita perseguição dentro da fábrica, e é um pessoal que não tem uma concepção ainda do que é um sindicato, pra que serve, como funciona, ou como deveria funcionar". Então em cima dessas conversas, Guilherme, dele com o Djalma e mais alguns outros diretores, que não consigo buscar o nome de todos agora, mesmo porque eu não convivi com o pessoal dessa época, tive mais informações desses nomes... Isso que estou te falando, devo lembrar que o João Felício também participou da diretoria nessa época.

Começaram então a articular com o sindicato pra se desvincular do sindicato de São Paulo. Que esse sindicato de São Paulo, tão logo nasceram as indústrias em São Bernardo, principalmente as montadoras, que foi por volta do ano de... já foi bem lá pra trás, já não é da minha época, em torno de 59, 60, por aí que começaram a montar os primeiros carros. A Scania, e assim foram expandindo outras. Mercedes, Volks. E começou a aumentar muito o número de funcionários, sem ter uma diretriz de sindicato que respondesse às expectativas. Então nessas discussões que o Lula estava fazendo, ele usou esses argumentos, que os trabalhadores eram usados de uma maneira que os donos do poder quisessem fazer, porque não tinham concepção. Não tinham informação de como o sindicato lá fora já tinha avançado. Aí começou a fazer essa discussão. E como os patrões tinham gente paga no meio pra ficar observando o que poderia estar acontecendo nessas organizações. Isso ainda no 
regime militar, no auge do regime militar. Passavam pra eles essas informações, onde eu tive essas reuniões dentro da empresa, onde os diretores falavam: "Vocês têm que tomar cuidado, porque tem um nortista que está com um discurso meio atrapalhado, um discurso de comunista". Sempre usavam essas palavras que chocavam muito as pessoas. "Isso é muito perigoso, pode fazer com que todos nós fechemos nossas portas. Não dá pra trabalhar com comunista". Essa era a posição da maioria dos dirigentes de empresas na época. Quer seja dono, quer seja dirigente. Naquela época as multinacionais eram pouca coisa. Eram só as montadoras mesmo. As outras, a maioria eram indústrias de origem estrangeira, mas seus presidentes eram brasileiros. Boa parte deles eram até donos de pequenas empresas. Isso deixou muito chocados os empresários. Foi aonde eles foram se organizando, faziam essas reuniões internas.

Por outro lado, o sindicato já começou a trabalhar essa questão. O Lula já começou a trabalhar essa questão. O Djalma topou essa proposta: "Você, Lula, acho que tem razão. Eu acho que a gente precisa realmente criar um sindicato... criar, ou construir, ou reformular um sindicato que esteja realmente respondendo o interesse dos trabalhadores. Passando pra eles as informações, como funciona o sindicato". Até se baseavam muito nas práticas dos sindicatos italianos. Se usava muito isso aí como parâmetro pra estar discutindo.

E aconteceu que o Lula montou uma chapa e venceu as eleições no ABC. A partir daí começaram então a vir as problemáticas todas. Foi uma derrota incalculável pra classe patronal. Que eles sabiam que iam mexer com muita coisa, como mexeram mesmo. Se brigava por pouca coisa, tinha que fazer greve. Se fosse necessário, se fazia greve. E aí começou a conscientização. $O$ sindicato começou a chamar os operários pra ir até a sede do sindicato. E aí já foram proporcionadas um monte de palestras, de cursos, se criou apostilas, se criou tribunas. Então tudo isso aí era um meio de formação.

Só que lá no início, nós estamos falando de década de 70 ainda, isso era muito complicado. Que até para você distribuir papel pra você divulgar uma palestra, ou divulgar uma nota, ou um recado que você quisesse passar. A gente não tinha liberdade de forma nenhuma de ficar com papelzinho debaixo do braço folhetando, como se faz hoje. Hoje é fácil, naquela época não era assim. Pra gente espalhar uma notícia do sindicato, ou uma possível greve, ou denunciar uma possivel falcatrua, os militantes tinham que passar por um processo de formação, que tinha que se dar muito rápido, senão você não conseguia acompanhar a evolução do tempo. Como se dava isso? Os primeiros passos foi alguém fazer esse documento, bem escondido, que era pra ninguém saber quem eram realmente os autores disso aí. Então se arrumou um monte de nomes de autores conhecidos, que eram companheiros, e outros nomes mais que eles davam. E pra distribuir era assim: digamos que nós dois estávamos com a incumbência de espalhar essas notícias em uma determinada fábrica. Então um de nós ia na frente, como se um não conhecesse o outro, com um pacote. De repente, você deixava isso cair, e o que vinha atrás, despercebidamente, tropeçava naquilo e espalhava, e aí pessoal passava e catava e começava a ler. E aí, ninguém sabia quem deixou cair. O cara sumia. Cada um entrava pra sua fábrica e não tinha nem como perguntar como isso funcionava. E isso começou a funcionar de militante pra militante. Era uma forma que a gente tinha de divulgar como se organizar dentro do sindicato. E aí um bom tempo foi assim. Imprensa, esquece. Era inimiga número um, não tinha como confiar nesse pessoal de jeito nenhum. Não divulgava nota nenhuma em jornal, nem na imprensa falada. 
Televisão quase nem existia, era só a elite que tinha na época. Então era super complicado. E pra você ter uma idéia: aconteceram esses fatos com mais freqüência, foi durante aquele ato institucional, o AI-5. A gente viveu aquela época, a gente considera que foi uma das piores do regime militar. E eu fiz isso, outros companheiros fizeram. Só que a gente usava essas táticas. Digamos assim que eu trabalhava a um quarteirão daqui, eu ia fazer esse trabalho a dois quilômetros daqui. Fazia esse trabalho e voltava pra casa de ônibus, ou de outros meios que dessem pra vir, e ninguém ia descobrir quem foi que fez isso aí. Ia trabalhar normalmente, se por alguma eventualidade qualquer fosse levantada alguma suspeita, eu tinha como provar que não era eu, porque tal hora eu estava na fábrica, tinha o cartão marcado. Uma coisa até bem organizada. E essas coisas foram se espalhando, Guilherme. Até ir pegando outras dimensões. A partir desse acontecimento, a perseguição foi aumentando por parte da polícia, principalmente o pessoal que trabalhava a serviço do AI-5. As perseguições ficaram bem mais severas e a gente teve que tomar mais cuidado. Já não dava pra fazer esse trabalho de deixar cair pro outro catar. Então você já tinha que aplicar outros golpes, outros tipos de coisa pra tentar encaminhar essa coisa. E aí, foi crescendo o número de pessoas descontentes, porque as informações que vinham nesses documentos falavam da nossa dura realidade. A falta de assistência, o baixo salário, a longa jornada de trabalho e as péssimas condições de ambiente de trabalho. Máquinas sem equipamento de segurança. Água: você não tinha água nem filtrada, banheiro era de qualquer jeito, não tinha papel higiênico. Comida: das firmas menores, nenhuma tinha. Só mesmo nas montadoras. Então era uma briga para os caras entrarem nessas firmas grandonas, Mercedes, Scania, Volks, Ford. Todo mundo queria, porque o rango... se você comparar com o de hoje, naquela época era sucata, mas pro pessoal estava bom demais, pois não conheciam aquilo ali. Então como essa coisa foi passando de cabeça a cabeça, surgiu a idéia que só lá no sindicato a gente não ia avançar muito. Com a ação do AI-5, você ia sendo espremido, espremido, e chegava uma hora que você estava totalmente controlado. Aí, começou a ganhar dimensão maior quando começou a espalhar para as comunidades de bairro. Aí vinham as associações, quando você tinha certeza que as pessoas eram confiáveis, que você poderia confiar naquela pessoa. Não a ponto de chegar em uma reunião e expor isso. Você tinha uma diversidade de pessoas ali, e ninguém poderia garantir pra gente, que até espiões tinha. Isso não era seguro de forma nenhuma. Então com o decorrer do tempo, das conversas, das palestras, quando as pessoas iam se manifestando, você ia descobrindo quem era quem, pra se identificar com o trabalho do sindicato, e ser um agente transformador dessa idéia, pra ver o que poderia estar fazendo.

Os anos 70 foram basicamente todos assim. O bicho pegou feio. A época da repressão foi complicada mesmo. Mas eu diria pra você sem medo nenhum de errar. Foram os anos das leis mais duras dos militares, mas foram os anos em que a população mais evoluiu. Houve uma necessidade de o pessoal evoluir. Se muito embora a cultura, digamos assim... não sei o nome técnico pra estar falando... a questão da escolaridade, era baixíssima. Quase ninguém tinha nem a quarta série. Era muito baixo o nível de cultura das pessoas. Mas o trabalhador sempre foi inteligente, ele sempre conseguia associar uma coisa à outra. E aí aquelas comparações que a gente fazia: quanto você produziu por dia, e o quanto iria pro segmento da empresa, o quanto sobraria pro Estado, e a parte que você podia fazer. Chegava-se à conclusão que uma hora que você trabalhava, você já cobria suas despesas. O resto era lucro pro patrão. Essa consciência foi crescendo, foi crescendo, e daí começaram a surgir alguns 
movimentos mais fortes no sindicato, ou seja, liderados pelo sindicato, ou encabeçado pelo sindicato.

Só que começaram a acontecer algumas coisas bastante atrapalhadas. Tudo que a gente fazia em reunião, e houve diversas reuniões, e depois a gente afunilava em uma grande assembléia e colocava em votação, isso era desfeito por lei. A lei não dava cobertura pra gente. Os militares tinham o poder, então eles mandavam e desmandavam. "O sindicato agora serve, agora ele não serve. Sem ele está ruim, então vamos tentar articulá-lo novamente". E foi aquela coisa. Só sei que tudo que a gente conquistava através das reivindicações, de várias formas, era cercado por cima. Então a questão do sindicato foi muito complicada. Houve muito conflito, muita prisão, pessoas que sumiram. Bastante complicado. Tanto é que, baseado nessas comunicações todas, isso ainda na década de 70, numas discussões mais filtradas, vamos falar assim. Se trouxesse para os tempos de hoje e você tivesse que discutir um assunto da suas especialidade, você ia pegar um grupo da sua especialidade pra discutir aquele tema. Se eu tivesse que discutir um assunto da minha especialidade, eu ia pegar mais aquele pessoal pra aprofundar aquela questão. Então às vezes até nem era muito apontado pela própria direção, mas às vezes era eleito um núcleo e outro, pessoas pra fazer essa discussão. Aí vinha gente com a formação maior pra clarear nossas idéias, que a gente precisava cercar isso lá em cima. Daí foi que o sindicato viu a necessidade: "Não adianta só organizar o trabalhador, só fazer enfrentamento com o patrão, porque eles têm todas as leis que favorecem eles. Tudo o que a gente conquista aqui, como eles têm representantes lá em cima, pessoal breca por decreto-lei. E decreto-lei é decreto-lei, não tem como você bater contra. A não ser que você derrube aquilo”. Foi daí que... eu não sei se a gente está queimando algumas etapas, que existe um monte de procedimentos no decorrer desse tempo pra ter chegado a essa posição, que seria necessário que a gente começasse a eleger pessoas, do meio dos trabalhadores, pra ir pro Congresso. Isso em todas as esferas, no Congresso Nacional, na Assembléia Legislativa e nas câmaras dos municípios. Para ter lei que nos garantissem. Foi uma pauleira danada. Não tinha como você legalizar nada, pois estava em um regime autoritário. Isso acabou gerando intervenção no sindicato, os caras intervieram. Expulsou os dirigentes sindicais, uns perderam o emprego, outros foram torturados. Cada um se virou da maneira que pôde.

Tivemos ainda a sorte que uma instituição muito poderosa no Brasil, que é a Igreja Católica, não me lembro que papa estava comandando a igreja nessa época. Uma fracção [facção ou fração] da igreja decidiu apoiar esses trabalhadores do sindicato. A Igreja Católica abriu as portas. Então a gente poderia fazer reunião em algumas igrejas. Não em todas. Como eu disse, era apenas uma facção da Igreja Católica. Porque tem umas que, Deus que me perdoe, até hoje não dá nem pra conversar, é muito complicado. Aliás, hoje a maioria é assim. Mas na época tinha uma fracção mais orientada pelos italianos e franceses, e alguns espanhóis também, que ajudaram bastante nessa questão. Então tem dois nomes que eu faço questão de frisar ao te contar como foi esse movimento no sindicato nas décadas de 70 e 80. Um está vivo ainda, está bem decadente. O outro morreu há dois ou três meses atrás, mais ou menos, que é o D. Luciano Mendes, um ex-cardeal. Esse colaborou demais com a gente. Eo outro está encostado, parece que estava até internado há alguns dias. É restrita a visita a ele, não é aberta pra todo mundo. Muito embora contra a vontade dele, mas a ordem deles determina assim. É o D. Paulo Evaristo Arns. Inclusive o regime militar o enquadrou como o 
homem mais perigoso na época. É o que mais fez frente a eles. Eu pude presenciar algumas ações dele. Muito bom aquele cara. Então nisso, a gente conseguiu avançar bastante.

Com esses apoios, em cima das nossas necessidades, saiu então a necessidade de se criar um partido, porque não dava pra você lançar candidatura de algum nome pelos partidos conservadores da época. Você ia ter que ter obediência ao partido, senão você ia ser expulso, e não ia nem ser ouvido. Então nasceu essa necessidade. Aí foi que o sindicato, no meu ponto de vista, começou a perder um pouco a sua identidade no local de trabalho. Foi a partir de quando começou a pensar em uma coisa maior. Vão ter que criar primeiro alguns vereadores, alguns deputados estaduais, alguns federais, senado, pra amparar a gente lá por cima. E isso começou a gerar muito trabalho. Às vezes a gente deixava de fazer uma discussão mais voltada direto pra questão do dia-a-dia do trabalhador pra fazer uma discussão das táticas que você teria de usar pra eleger o fulano de tal. Mas tinha um ponto importante nessa época, Guilherme, eu não sei hoje, como vocês que são novos enxergam isso, eu considerei muito importante naquela época. E continuo acreditando que isso não poderia ter sido perdido de vista de jeito nenhum. Não era só eleger sindicalista ou trabalhador pra cercar ali lá pra cima, mas precisaria fazer um grande número e tentar provar pra elite que o sistema em que a gente vive é um sistema que não funciona. Antes de tudo você teria que derrubar esse sistema. E eu sou um dos que cheguei a defender que não seria via voto pra mudar isso aí. Teria que fazer algumas organizações, mesmo depois que a gente começou a adquirir um pouco mais de conhecimento, a gente começou a conhecer as limitações que a gente tem. A questão da formação, de você conhecer geograficamente seu país, seus pontos estratégicos. Ninguém saberia lidar com armas. Nós chegamos a pensar em uma época em querer tomar o poder na base da porrada, da bala mesmo. Chegar, subir a rampa, e falar: "Chega! Agora é nossa vez, já fizeram muita cagada”. Mas, tem uma maioria que pensou diferente e falou: "Não, vamos fazer isso por uma via saudável. Ou seja," na linha de raciocínio de alguns amigos meus "vamos brincar de bobo". Quando você vai conseguir que o sistema capitalista proporcione uma boa condição de vida para o trabalhador? Eu, por exemplo, nunca perdi isso de vista. No conflito capital e trabalho, quem sempre vai levar mais vantagem vai ser patrão. Ele tem o maior poder disso aí. Mas infelizmente... ou felizmente, essas coisas aconteceram. E junto com isso aí, uma coisa bem complicada, junto com esse conjunto de coisas que estava acontecendo, dentro do sindicato começou a gerar divisão. Tinha aqueles que defendiam essa linha de raciocínio que eu acabei de falar pra você. Tinha outros que defendiam uma outra linha de raciocínio, que tinha que ser no diálogo, no voto, na lei. E aí começou a gerar os conflitos dentro da própria classe trabalhadora: as maneiras de pensar.

Só que aí se criou dentro do sindicato, antes de consolidar o partido, que a gente precisava dele para ter a lei, dentro do sindicato já começou a acontecer essas coisas que a gente costuma chamar de rolo compressor. O que é o rolo compressor? Aquele pessoal que tem o poder na mão, ou seja, aquele que está com a presidência, ou que tem um grande número de delegados do lado dele. Então ele vai pra assembléia e aprova as medidas que ele acha que é melhor. Não interessa a opinião dos demais, não se abre pra fazer um debate. Você respeita uma outra chapa. Então olha, se nós dois somos de chapas opostas, e eu preciso de quinhentos votos, eu tenho como bancar isso. Então eu começo a mandar perua pra cá, perua pra lá, oferecer lanche, e eu levo quinhentas pessoas pra votar favoráveis a 
minhas idéias. Agora você que tem um poder de fogo menos, vai conseguir levar no máximo cem pessoas, duzentas. Porque você vai levar pessoas conscientes, pessoas que vão lá pra fazer uma discussão pé no chão, uma coisa madura, já fruto de um trabalho de conscientização. São pessoas que não estão esperando o ônibus que as levem de graça. Ele tira do bolso dele pra pagar condução pra ir. Se tiver que tomar um lanche, porque a discussão é demorada, ele tira do bolso dele pra se alimentar. Se for o caso até de ter que fazer um seminário de um dia pra outro, dormir de qualquer maneira, ou cada um paga sua parte. Se virava do jeito que pudesse, enquanto os outros tinham todo conforto. Essa coisa já aconteceu dentro do sindicato. E isso hoje, nesses tempos de agora, dá pra você perceber isso, que já é da sua época. O que está acontecendo no Partido dos Trabalhadores acontecia lá no sindicato. É bom deixar bem claro que não foi com a mesma dimensão, porque roubo, a gente não conseguiu detectar desvio de dinheiro, assim estupidamente. Se houve alguma coisa, eu desconheço.

Algumas discussões que nós fizemos na época até para subsidiar a Nicarágua foram propostas, a gente conseguiu que passasse, conseguimos até dar um pequeno subsídio pra Nicarágua na época. Estou falando do sindicato e de repente entra essa questão da Nicarágua. Mas quem sofria lá na Nicarágua não era patrão, era operário também. Então a gente tinha consciência. Na época que os opressores da Nicarágua determinavam os ataques era a época da safra do café. "Qual é o forte deles? É café. Vamos pra guerra, eles vão vir combater a gente, eles perdem o café e perdem o recurso financeiro". Então eu conheço várias pessoas que foram, infelizmente eu não pude ir. Já era casado, já tinha família, tinha uma responsabilidade. Não era só minha vida que estava em jogo, tinha mais gente por detrás de mim que corria risco também. Eu não pude prestar esse serviço. Gostaria de ter ido ajudar o pessoal da Nicarágua. Enquanto os nicaragüenses estivessem guerreando, a gente estaria colhendo o café para garantir o recurso deles. Isso eu nã pude fazer, mas vários companheiros meus fizeram.

E voltando lá pro nosso sindicato, a coisa continuou rolando desse jeito. Se criou o partido, mas aí se viu que essas questão de parlamento teria que atender toda a classe trabalhadora. Todos os trabalhadores, que na época a força maior estava no Sindicato de São Paulo. Acho que a CGT, Central não sei das quantas dos Trabalhadores, que dividiu na época um monte de tranqueira. Mas até montamos chapa uma vez, pra concorrer no Sindicato de São Paulo, e isso foi na década de 70. Quem ganhou essa eleição pra presidência do sindicato, que tinha sede na Rua do Carmo, foram Valdemar Rossi, Anísio Batista, Santo Dias, que foi assassinado na porta Sylvania. Inclusive sábado agora vamos estar celebrando em memória dele, foi em 79, vai fazer trinta e poucos anos já. Eles ganharam, e quando os militares viram que haviam elegido a oposição do sindicato, eles deram um jeito de queimar algumas urnas. Aquele mapeamento, né? Tinha urna que só dava voto favorável a nós. E tinha urna que só era favorável a eles. Os militares conseguiram prender várias lideranças nossas aqui na R. Tabatingüera, Rua do Carmo, Praça da Sé, essas imediações, queimaram algumas urnas, prenderam o Valdemar Rossi, prenderam o Anísio Batista. O Santo Dias nesse dia não foi preso. Eles conseguiram dar posse ao Joaquinzão. Você já ouviu falar no Joaquinzão? Um ex-presidente do sindicato. Deram posse pra ele. Ele não ganhou as eleições naquela época. Ele levou o sindicato pelo pulso dos militares. Os coronéis empossaram ele no cargo, e deram a derrota pra oposição. E de lá pra cá a gente 
nunca mais teve força pra fazer frente pra esse pessoal. Qualquer unidade de fábrica que se montasse uma estrutura sindical que fosse contra as vontades do sindicato do Joaquinzão, aquilo era desfeito rapidamente. Ele já comunicava a empresa, a empresa já dava uma desculpa. Mandava esse pessoal embora, ou caía na mão da polícia, ficava desempregado e já estava condenado a ficar desempregado várias vezes.

Aí, em São Bernardo, parece que essa doença, apesar da discussão, o discurso que o Lula fez com os objetivos que ele tinha pra criar o sindicato, só que isso contagiou lá depois. Ele criou o sindicato com uma filosofia de trabalho, um determinado idealismo. Mas isso contagiou lá, e acabou gerando essa facção, algumas facções dentro do sindicato, e uma delas, a dominante, que a gente chama de rolo compressor, ou pelego. O nome mais fácil é rolo compressor mesmo, que passa por cima de tudo e predomina a vontade deles. E isso eu presenciei. Fui em várias assembléias onde a gente não tinha o direito... quer dizer, você tinha direito, mas não podia correr o risco de vida de manifestar a sua insatisfação com aquele acontecimento, que você estava correndo risco de vida. Você corria risco de ser dedado na fábrica que você trabalha pra própria direção, ser mandado embora e ser uma pessoa condenada a não arrumar mais emprego. Então, não tenho medo nenhum de falar pra você isso aí, porque eu acompanhei muito de perto isso e até o ano passado, que eu posso falar com propriedade, eu estava junto, a coisa no sindicato nosso funciona desse jeito. Prevalece a vontade daquela facção que tem o poder na mão, o domínio. E esse domínio, seria até legal que fosse fruto de um trabalho de conscientização, mas não é. É troca de favores. Tipo, vou facilitar a entrada do seu filho na indústria tal, teu marido, ou tua mulher. Vou facilitar a concessão do uso da casa de campo, ou da casa de praia, ou da consulta médica, ou da bolsa de estudo. E coisas mais ou menos parecidas. Num possível mandato meu, você pode ocupar um cargo lá dentro. Quando alguém dessa facção dominante sofria uma represália da empresa, que a empresa começava a pressioná-lo, a primeira medida que o sindicato faz é essa: o busca e o coloca na sede do sindicato pra fazer um trabalho de diretor. Muito embora, em 2005 aconteceu uma mudança importante. Digo importante porque há uma possibilidade de voltar ao que era. Mas ela foi criada com segundas intenções, ela foi criada para que em todas as fábricas, essa facção que tem poder de domínio controle aquilo ali. Se criou então o chamado sindicato de base, no piso de fábrica. Mas aquela questão, os caras são escolhidos lá pelo sindicato: "Você vai pra empresa tal". É tão sacana isso, Guilherme, que chegava a direção do sindicato a negociar com a direção da empresa, e dizer: "Eu vou estar mandando uma pessoa pra procurar emprego aí". E a empresa contratava essa pessoa, e dentro de pouco tempo o cara era um delegado sindical, um representante de comissão de fábrica, essa coisa toda.

Até voltando um pouco ainda dentro da década de 70, eu fui eleito alguns mandatos como CIPA - Comissão Interna de Prevenção de Acidentes, que é baseada na portaria 3214. Um monte de normas regulamentadoras. Salve engano, eram 29 e passaram a ser 32 normas regulamentadoras, e eu aplicava mais a de número 5, que tratava do assunto mais específico do acidente de trabalho. Então eu tinha esse suporte na mão pela CIPA, devido ao bom relacionamento que eu tinha com os colegas de trabalho, minha votação ia lá em cima. Às vezes até a empresava lançava candidato, o sindicato lançava candidato paralelo, divulgava ainda um documento. Eu nuca precisei ir lá no sindicato e falar: "Bota na Tribuna o meu nome aprovado por vocês”. Não, nunca aceitei isso aí. "Eu não quero rabo preso!” Falei 
isso dentro do sindicato. Eles me chamaram na reunião, e eu falei: "Eu vou trabalhar pra ser eleito, e tenho quase certeza que vou ser eleito, na fábrica que eu trabalho, pelos funcionários de lá, e juntos nós fazemos um bom trabalho. Mas eu não quero vir aqui pra perguntar pra vocês o que eu tenho que fazer lá. Já existem as normas. Como eu não quero estar na sala do diretor perguntando pra ele o que é que eu vou fazer. Já tem lei, foram criadas leis pra isso aí. Existe a portaria 3214 que dá todo suporte do que você pode fazer ou não. E qual vai ser minha outra instância de decisão? Uma discussão com os trabalhadores, no local de trabalho. Se eles acharem que tem que parar por um motivo A ou B, a gente vai parar sim. E aí vamos precisar do suporte de vocês". Aí tinha algum diretor metido à besta: "Mas se você não estiver cem por cento de acordo com nossos encaminhamentos, fica difícil apoiar suas decisões. A gente considera decisão isolada". Falei: "É uma absurdo isso. Eu não vou vir aqui ver meu interesse. Eu vou estar aqui trazendo a vontade de uma maioria. Isso eu já disse. A gente vai estar fazendo uma discussão e uma votação. O que a maioria decidir a gente vai encaminhar. Tendo já o sucesso lá, ou seja, o resultado, eu nem vou envolver vocês no assunto. Não tendo esse respaldo lá, não conseguindo tudo isso lá, vocês são uma instituição legalizada, à qual a gente é filiado, a gente paga, e eu vou contar com o respaldo de vocês”. Então eu fui eleito pra CIPA, dois mandatos consecutivos. Um primeiro com uma votação boa, conseguindo uns quarenta e poucos por cento dos votos, que eram vários candidatos. Aí eu tive um ano de mandato, e ficava gozando de estabilidade por mais um ano. Só que abri mão desse ano de estabilidade, lancei meu segundo mandato. Isso permitia uma avaliação. Falei: "Isso é um desafio pra mim. Eu estou há um ano na CIPA, não tenho muito respaldo da direção do sindicato. Sou muito questionado pela direção da empresa. Mas eu vou lançar esse desafio. Vou me inscrever e vou ver qual avaliação eu tenho na urna". E foi uma surpresa das maiores que eu pude ter. Basicamente oitenta por cento dos funcionários da fábrica votaram em mim. Foi uma coisa que deixou o sindicato coçando a cabeça. Quer dizer, os dirigentes do sindicato; o sindicato somos nós, os trabalhadores. Deixou eles coçando a cabeça. A direção da empresa ficou louca, não sabia o que fazer. "Poxa, mas o que você faz? Como você compra tanto voto assim?" Falei: "Com o salário que vocês me pagam”. [risos] Falei na base da gozação também. E isso, Guilherme, gerou uma preocupação tão grande na direção da empresa, que ao terminar esse segundo mandato, me gerava mais um ano de estabilidade. Porém eu não tinha direito de lançar minha candidatura novamente. Só se permitem duas eleições. Eu posso cumprir o mandato e ficar um ano fora. Ou reeleger e dar continuidade ao mandato. Só que com esse esquema aí eu acabo diminuindo a estabilidade em um ano. Se eu tiver o mandato de um ano e ficar um gozando da estabilidade, eu posso me eleger. Eu me reelegendo eu perderia. Eu sendo reeleito, eu ficaria mais dois anos, mais um de mandato, e aquele outro ano que eu teria, eu teria que abrir mão dele por ter lançado minha candidatura. Só que ao término desses dois mandatos, com essa votação expressiva, gerou uma preocupação tão grande na direção da empresa. O que eles fizeram? Quando estava terminando, que a gente ia jogar o edital de convocação pra fazer uma nova eleição, a direção da empresa me convidou a uma reunião, me propôs que eu assumisse a presidência da CIPA. O presidente não é votado, é escolhido pela direção da empresa. Pensei bem e falei: "Caramba, vai ficar meio confuso isso. Antes de deixar isso na mão de qualquer um, é melhor eu segurar isso. Estabilidade eu tenho por um ano”. Eu li o regulamento da empresa, não ia jogar por água abaixo aquela estabilidade que 
eu tinha. Eu pensei que fosse só jogada deles, que se eu aceitasse, a hora que terminassem as eleições eles me descartavam. Mas eu li direitinho, inclusive eu fui lá na sede do sindicato e pedi uma cópia da convenção coletiva, li o item direitinho. Aí peguei a presidência da CIPA, de maneira que eu tive dois mandatos eleitos, e um representando o patrão. Mas era gozado, porque eu cutucava o pessoal que foi eleito pra pedir as coisas: "Pô, pede as coisas, que agora que eu estou na presidência é mais fácil impressionar isso pra ir pra ata”.

Mas era assim, na questão do sindicato, você não tinha um grande respaldo. Mesmo tendo essa popularidade toda que eu tive na fábrica, eles tinham muita preocupação de manipular minha idéia pra se aliar a essa facção do rolo compressor. Não fiz isso, não. Não posso me vender de forma nenhuma. Isso aí, Guilherme, tem um certo peso pra gente.

Eu acho que já disse isso pra você em outro momento, e vou repetir porque faz parte faz parte da trajetória do sindicato. Eu, como sindicato também, não como diretor da entidade, mas como sindicalista praticante, como eu fui. Esse filho mais novo que você conheceu agora, fui conhecê-lo com três dias de idade. Foi em fim de 84, começo de 85. Isso aí a gente começou no final de 84. Ele nasceu em janeiro de 85. Quando minha esposa foi para o hospital pra dar a luz, eu estava coordenando uma greve na fábrica. Eu não podia sair naquele momento de forma nenhuma, porque a gente era a pessoa que estava mais com o pé no chão. Eu não ia pro boteco beber pinga pra não falar besteira. E ficava de olho no que estava acontecendo ali pra gente fazer a jogada toda, negociar, participar com a direção do sindicato, participar com os companheiros. O telefone naquela época não era tão fácil pra gente ficar ligando. Mas aí eu tinha notícia quando chegava em casa, na tarde da noite: "Como é que está? Está tudo bem?" "Está tudo bem". Tinha na minha cabeça assim: lógico que o apoio moral é super importante, mas minha companheira, com meu filho, está no hospital. Creio que estão tendo todas as assistências. Aqui, se eu arredar o pé, muitas cabeças vão rolar. Muitos direitos conquistados vão rolar também. Então isso foi o motivo básico, não querendo justificar, que me levou a me comportar desse jeito.

Agora, muita coisa chocou. Lógico que durante todo esses meu tempo na CIPA, não vou dizer pra você que fiz tudo numa linha esquerdista, radical. Não. Teve momento que eu fazia negociação. Por exemplo, pulando dos anos 70 pros anos 80 , veio aquela confusão toda. Houve a necessidade da criação de um partido. Como, comecei a falar e não continuei, os parlamentares teriam que representar todos os sindicatos, e o Joaquinzão não passa na nossa garganta até hoje, aí gerou essa questão de criar uma Central Única dos Trabalhadores. E filiar o máximo de sindicatos que pudesse com uma linha única de ação bem diferente do sindicato conservador, o sindicato pelego, como a gente chama, aqui de São Paulo. Falei mais do Joaquinzão, mas vieram os sucessores dele, que são o Medeiros, e aquele que foi ministro do trabalho, aquele lá da cachorrinha... como é o nome dele? O... Magri. $O$ da cachorrinha. [risos] E veio agora esses outros cabeças de bagre, todos com a mesma linha de ação. Mas eu fiz algumas negociações nesses mandatos meus. Nessas transições, a gente precisava de povo na rua. Aí tive até respaldo do sindicato, como instituição. Eu negociei com a empresa na época assim: "Na questão das Diretas Já, nós precisamos também participar”. E eu discutindo isso com a direção da empresa e com os trabalhadores. "Nós não podemos ficar alheios a essa discussão." A direção da empresa nunca apoiou essa idéia, porque eles não abriam mão do sistema de governo. Pra eles tinha que continuar a linha dura e pronto. Mas eu consegui falar: "É a vontade da maioria, todo 
mundo está querendo participar disso. Se a gente não negociar, o que vai acontecer? Muitos vão faltar ao serviço. Vai quebrar a produção. Então eu proponho a vocês o seguinte: a gente pode estar negociando. Vocês liberam tantas horas pra gente ir participar, e depois a gente repõe essas horas. Aí vocês não descontam da gente. Vocês não vão perder a produção e nem nós vamos perder nosso salário. Eu não tenho dúvidas nenhuma, e vocês têm até suas razões. Se eu faltar pra ir correr atrás de coisas que eu acredito, e pode até estar contrariando seus princípios, eu vou estar ferindo a lei do trabalho e dando o direito a vocês de aplicarem as penalidades que julgarem necessárias. Descontar as horas que eu faltei, descontar minha remunerada. Não sei se você têm suporte pra advertir ou alguma coisa parecida, mas eu não duvido muito que isso possa acontecer. Então vamos evitar esse conflito. A gente vai, participa do ato, e a gente volta depois pra negociar com vocês. A gente vem repor em dia de sábado, ou a gente vai ficar até mais tarde”. E assim eu fiz essa negociação quando foi pra chamar as Diretas Já. Quando foi pra gente fazer a defesa da indústria nacional, naquela questão das besteiras que o Collor começou a fazer, quando foi eleito. Nós fomos ao centro da cidade, no Palácio das indústrias. Um monte de ônibus. Em defesa da indústria nacional. Como a gente foi pra rua - isso dentro do meu mandato de CIPA, ainda - reforçar o impeachment do Collor, pelas burradas que ele fez. Nessa do impeachment do Collor já não foi muito difícil pra negociar, porque a empresa também estava se sentindo prejudicado com isso. Não sei como está escrito na história do Brasil essa coisa toda, mas me lembro bem que o pontapé inicial nós demos no ABC. Isso começou a ganhar dimensão, as cagadas que ele fez. E a mídia partiu pra cima, os cara-pintadas entraram em cima. Então hoje, eu acho que se surgir uma pergunta na história de quem que encabeçou isso aí, eu não teria medo de dizer que os caras vão dizer: "foram os cara-pintadas". Mas essa discussão nasceu lá embaixo. Não podemos desprezar de forma nenhuma a participação dos estudantes, foi importantíssimo. Sem a quantidade de estudante que foi com a gente pra Paulista, Ibirapuera, ficaria meio comprometido o impeachment do homem. Mas juntou central sindical, os movimentos populares e o movimento estudantil, isso deu um impulso muito grande pra acontecer o impeachment do Collor.

E aí essas questões do sindicato na década de 80, Guilherme, ela veio mais ou menos desse jeito: sempre elegendo um presidente que fechava com todas as idéias daqueles que se diziam dono da verdade, aquilo que eu chamei de rolo compressor. Aqueles que tinham o poder na mão. Por exemplo, vamos começar: o Lula foi o primeiro presidente do sindicato que tinha essas idéias. $O$ sucessor dele já foi o Jair Menegueli, que era apoiado por ele. $O$ sucessor do Jair Menegueli era o Vicentinho, que já era apoiado pelo Jair Menegueli. $O$ sucessor do Vicentinho... quem foi... quem foi antes do Luiz Marinho? [longa pausa para lembrar] É , foi o Luiz Marinho, e já foi apoiado pelo Vicentinho também. Aí vêm aqueles pulinhos. Delegado, diretor de fábrica, diretor do Sindicato, virava presidente do Sindicato, pulava pra presidente da CUT, depois que criaram a CUT. O primeiro presidente da CUT foi o Jair Menegueli. O Lula não chegou a ser presidente da CUT. Ele foi um dos que participaram da criação, mas como partidário, ele não chegou a ocupar o cargo de presidente da CUT. Ele foi um dos que alavancou a CUT, mas nesse momento ele estava voltando a vida dele mais pra política partidária que pro sindicalismo. Apoiava o Sindicato, mas defendendo tese. Não é à toa que ele foi o deputado mais votado da época, na composição da constituição de 88, os constituintes. Até que ele disse que tinha quinhentos e 
poucos picaretas em Brasília. Ele foi pra lá e esse pessoal continua picareta até hoje. [risos] A picaretagem continua. Aí vem pulando, com a chegada dele no poder, o Menegueli foi eleito federal. $O$ Vicentinho também foi eleito deputado federal. Ocupou, como eu já disse, a presidência do Sindicato, a presidência da CUT, aí já veio pra política partidária, hoje é deputado federal, foi candidato a outros cargos, mas não foi eleito. O Marinho, Luiz Marinho, é a mesma coisa. A gente teve várias reuniões com ele. Hoje, de presidente do Sindicato ele foi pra CUT, da CUT ele foi pro ministério do trabalho, e está fazendo as besteiras que está fazendo em Brasília. Eu fico p. da vida, rapaz, quando vejo o Luiz Marinho que eu conheço, com as idéias boas que tem, chegar e falar tanta besteira assim como ministro. Meu Deus! Como é que pode um cara mudar tanto assim? Será que ele ficou tão horrivel de uma hora pra outra? Será que ele já deixou de ser o fabricante das montadoras, aquele que está na linha de montagem, e agora está pertencendo à direção da Volkswagen? Será que ele virou alemão? Pô, que diabo que é isso aí? É muito complicado. E ultimamente agora nós temos o Feijó, José Malta Feijó o nome dele, que é o atual presidente do sindicato, que mantém... essas coisas não tem muito como mudar, não. A maior resistência de sindicato de oposição, o sindicato que prega um trabalho mais digno pro trabalhador é uma organização da Mercedes-Benz, da Scania. Da Volks, não. Da Ford também não. Volks e Ford sempre foram, e acredito que enquanto elas existirem por aqui, elas serão a base de sustentação do presidente do Sindicato do ABC. Porque ali, a maioria dos que compõem o rolo compressor, as chamadas convenções, o legado que volta às teses, estão todos elogiando os outros. De vez em quando um tenta fazer outra discussão, mas aí ele é chamado lá no tronco. Os caras chegam junto neles e ele muda de posição ou sai fora. Na próxima convenção que tiver, ele nem participa mais como delegado. Cada pessoa porreta, rapaz, que se lançou, se inscreveu dentro dos critérios normais do sindicato, pra ser delegado sindical.

Meu! Não sei se você conhece o Pavilhão Vera Cruza ali em São Bernardo. Se um dia você tomar o trole pra ir praqueles meios de lá, tão logo que você passar sobre o Viaduto Anchieta, desse lado de cá você vai olhando que você vai ver o Pavilhão Vera Cruz. É bastante falado aquele lugar. $O$ Sindicato alugou algumas vezes pra gente fazer essas assembléias. Mas existe uma infinidade de filmes que foram gravados ali. Cinema, teatro. Tem uma história muito bonita o Pavilhão Vera Cruz. Então eu participei de algumas convenções ali. Tirada de delegado é terrível. Agora não precisa mais, porque tem um salão muito grande nas dependências do Sindicato de São Bernardo. Tem um auditório muito grandão. É gozado que lá já tem carta marcada. Tem uma ala, vamos dizer assim, ala governista. [risos] E tem um outro pessoal que já se encosta em um outro canto lá, que são aqueles que fazem oposição, que querem um sindicato diferente. E essa coisa vem brotando em vários segmentos, e, sei lá, pode ser que eu esteja errado, mas acho que é um prejuízo pra classe operária. Como isso aconteceu no Sindicato, na CUT, e hoje no Partido. Partido que nós criamos no passado com uma carta de princípios. Tinha um objetivo. E virou essa porcaria que virou hoje. Temos um governo com uma pessoa na qual a gente acreditava. Está no governo e está fazendo jogo do outro lado. Como dizem alguns companheiros da gente, entre os males é o menor. Ele está atendendo o interesse da burguesia, mas não está deixando o pessoal morrer totalmente de fome. Está sobrando alguma migalha pra esse pessoal do interior. O famoso fome zero, bolsa-família. Existe alguma coisinha. 
Mas frisando aquela parte que eu disse lá atrás, dentro desse sistema não tem como melhorar muito, não, Guilherme. Se não mudar o sistema, nós vamos viver eternamente isso. E aí na questão das fragmentações, que nós chagamos a ter no Sindicato, em muitas organizações, hoje está no partido, o que aconteceu lá atrás, lá no governo da Luíza Erundina, uma fração, que tem a sigla PSTU, foi expulsa do Partido. Depois se criou uma outra com o nome de Causa Operária. Também, fora do Parido. E a última, agora, foi essa da Heloísa Helena. Não sei se é muita coerência dela, se é incentivo de outros setores, ou se é cagada mesmo dos parlamentares. E aí se for cagada dos parlamentares, é coerência dela. Criou-se esse outro partido, que é o PSOL, que por sua vez é a primeiro participação como partido, e teve uma votação, no meu ponto de vista, até bem elevada. Chegou na casa dos seis por cento de votação. Inclusive eu, particularmente, votei nos candidatos não do executivo, mas do legislativo. Eu acredito no trabalho deles, porque eles defendem nossa carta de princípios. O Ivan Valente, deputado federal. E o Carlos Gianazzi, que não sei se chegou a ser eleito, preciso ver a lista, deputado estadual. Carlos Gianazzi deu um trabalho danado pra nós, que quando a Marta era prefeita, eles montaram um esquema que ela mexeu nos recursos da escola, e ele foi defender nossa carta de princípios e a elite do partido propôs a expulsão dele. Naquela noite, nós ficamos até umas duas horas da manhã nas imediações do Hospital São Paulo, onde é a sede nacional do Partido... nacional não, é do estado. Eles iam expulsá-lo, nós não deixamos, não. [inaudível] tremenda democracia, e a gente lá de porrete na mão mesmo. Fechamos rua, ameaçamos dirigente de partido, parlamentar. "Se tem alguém certo aqui, é ele, que está defendendo nossa carta de princípios. Errados estão vocês. Estão seguindo ordem de uma loirinha que nunca foi trabalhadora na vida dela, e que ganhou a prefeitura de São Paulo". Hoje eu posso até falar pra você que eu gosta da postura da Marta. Eu acho ela uma pessoa inteligente, coerente. Ela enfrenta os problemas como eles são. Ela não é medrosa. Desmantelou a máfia dos transportes. Ela aceita os filhos dela do jeito que eles são. Separação do marido. Isso é um ato de pessoa corajosa. Não é todo mundo que tem coragem de fazer isso numa vida pública. Mas isso é doidice. Esquece. Marta não tem nada a ver com o PT. É uma loirinha que nasceu no berço de ouro, sempre comeu do bom e do melhor e pegou essa carona. Casou com uma família muito rica, os Matarazzo. Acho que ela também é de uma família tradicional, tem as raízes dela. Se juntou a uma riqueza danada. Já o Suplicy, apesar de ser de uma família tradicional, todo mundo sabe que ele abriu mão de um monte de coisa da família dele pra se dedicar à vida pública. E eu o admiro, admiro muito.

Aí até peco desculpas, porque sua pergunta era uma, e a gente acabou falando de outras coisas. É porque uma coisa é conseqüência da outra, viu Guilherme? Não teria jeito de eu falar só do Sindicato em si. É o sindicato e as conseqüências geradas por ele, até chegar na época de hoje. Eu não sei se responde às suas expectativas essa afirmação.

Ainda sobre o Sindicato, você pertencia a algum grupo político, desses que você citou? Como você se situava politicamente na época que o Lula assumiu o Sindicato?

Quando o Lula assumiu o Sindicato, Guilherme, eu não tinha tanta... eu comecei a clarear mais os horizontes pra mim em cima das necessidades dos anos 70, ou seja, eu comecei a participar mais com o aparecimento do Lula. Quando se criou o Partido, eu vi a sigla do Partido - PT. Então todos candidatos, para mim, tinham as mesmas idéias ou teriam que 
fazer as mesmas coisas. Eu jamais imaginava, talvez até por falta de estudo, ou tempo de aprofundar, que um presidente do sindicato, que criou um partido com um objetivo, deixaria infiltrar pessoas com idéias tão atrapalhadas. Não tenho vergonha nenhuma de falar pra você. Já votei em um cara que hoje eu olho, vejo o nome dele, foi reeleito deputado, que é o José Mentor. Considero-o um grande bandido, na minha concepção. Inclusive eu ajudei na campanha, ajudei, votei nele. Foi a primeira eleição do Partido dos Trabalhadores aqui em São Paulo, ele não foi eleito pra vereador. E eu fiquei sabendo depois que a Ford do Ipiranga patrocinava a campanha dele. Como pode, no auge da criação de um partido com idealismo, no auge do sindicalismo forte, você tem um candidato do partido sendo subsidiado por uma multinacional? Isso para mim foi o fim da picada. Falei: "Agora vou ter que conhecer um pouco mais”. A partir daí, meu amigo, eu tomei posição. Minha posição é a seguinte: eu sempre estou com a esquerda do partido. Ou seja, aquela ala do partido que defende, que os tradicionais do partido, os "donos da verdade", costumam tratar a gente de dinossauro. "Você não conseguiu acompanhar a evolução do tempo, que hoje os tempos são modernos, você tem que fazer aquilo e isso". Eu não abro mão dos meus princípios. Lá nos anos 70 eu era trabalhador, e hoje em 2006 eu continuo trabalhador. Nos anos 70 eu recebia salário. Hoje eu continuo recebendo salário. É a mesma coisa. Se eu comia feijão naquela época, eu continuo comendo feijão hoje. Se eu morava num casa humilde naquela época, hoje eu moro em uma casa humilde. Eu não deixei de ser trabalhador em momento nenhum. Não posso abrir mão dos princípios de quando nós criamos, ou o Lula criou, um sindicato de resultado, um sindicato progressista. Nasceu da discussão com o Lula. Quem trouxe isso pra ele, eu não sei te explicar. Como ele conseguiu, e nós conhecemos a história do Lula, de onde ele veio, o que ele fez e essa coisa toda, com certeza alguém o trabalhou muito bem pra formá-lo. Foi um cara inteligente pra fazer o que ele fez, não dá pra negar. Hoje, honestamente, não comungo com muita coisa que ele faz, e principalmente os grandões do partido fazem. Não estou de acordo de forma nenhuma. Pra você ter uma idéia, quando o Roberto Jefferson fez aquela denúncia, eu comentava com um cunhado meu e mais uns outros colegas de uma linha mais avançada, de uma visão mais progressista: "Olha, o Lula tem que chamar amanhã o Zé Dirceu e falar: 'Zé Dirceu, venha cá. O Valdomiro é seu homem de confiança, seu braço direito. Não é?' 'É.' 'Você é meu braço direito. Houve uma denúncia do Roberto Jefferson que diz isso, isso e isso. Você está fora do ministério. Vou pedir pro partido isolar você, até que se apure os casos. Que eu sei que a burguesia é complicada. Eles não medem esforço pra matar trabalhador. Mas você vai ter que provar o contrário. Você vai ter que provar que é inocente. Enquanto não provar sua inocência, você não vai ser mais meu ministro, muito menos o Valdomiro. Eu não vou transferir a culpa só pro Valdomiro. Você é o chefe dele. Então você que responde pra mim. Eu sou presidente, e nós fomos eleitos com uma bandeira pra isso, isso e isso. Portanto eu não posso aceitar essa podridão de forma nenhuma'”. Se o Lula tivesse feito isso na época, Guilherme, ele teria ganho no primeiro turno, e acho que as repercussões políticas no Brasil seriam bem diferentes. A moral dele estaria bem diferente. Aí tinha nossa bandeira de transparência, de honestidade, de coerência. Ao deixar de fazer isso, acho que o Lula perdeu. Não só acho, como tenho certeza, que os resultados do primeiro turno apontaram pra isso. Muito embora eu, por fidelidade à minha filiação, votei no Lula. Como votei no Mercadante, que não gosto dele de jeito nenhum, acho uma péssima pessoa pra governo, por ele ser um dos manobristas, um grande articulador do rolo compressor. 
Diria que ele é o motorista do rolo compressor. Ainda bem que ele tomou uma bordoada no meio da cabeça, quem sabe ele não reflete um pouco no senado, e não faz besteiras.

Mas aí, respondendo a sua pergunta, desde quando se começou a discutir a criação de um partido, com aquele objetivo que falei anteriormente, eu me filiei, ao partido. Militei muito tempo pelo partido, defendia com unhas e dentes do partido. De quatro anos para cá não faço mais isso. Um partido que abraça o sistema não é meu partido. Não posso falar que esse partido é a bandeira que eu carrego. Não, não. Minha bandeira não é essa. Minha bandeira é bem diferenciada, inclusive até alguns pontos da reforma agrária, reforma urbana, distribuição de renda, a gente tem uma posição bem diferente daquela que o partido prega. Você pode questionar assim: "Adão, você é a favor ou contra reforma agrária?" Dentro do sistema capitalista, sou contra. Eu não apoio reforma agrária. Explico: se nós fizermos reforma agrária no sistema capitalista hoje, não tenha dúvidas que daqui a dois anos as terras estarão concentradas nas mãos da minoria novamente. Nosso pessoal não foi educado pra isso, não vai saber controlar. Essas terras vão retornar todas. Pra eu defender a reforma agrária, defendo-a com a seguinte bandeira: vamos implantar reforma agrária agora em 2007? Vamos. Então a partir do momento que a reforma agrária for implantada, não existe mais comércio de terra. Acabou a comercialização de terra. A terra vai ser um bem comum, pra ser usada da melhor maneira, e zelada por todos. O responsável maior disso aí é o governo, que vai tomar conta. O dia que eu não quiser mais trabalhar nessa terra, eu vou pra uma outra terra, mas eu não tenho o direito de transformá-la em moeda. Ela vai ficar lá pra quem quiser trabalhar. E tem outra: durante meu tempo de gestão nessa terra, eu tenho o dever não só de usufruir, mas de cuidar também. Pra não ter tantos desastres ecológicos como a gente tem. Eu vejo um monte de gente: "Reforma agrária já! Reforma agrária urgente!'. Não vamos brincar de bobo, não, que isso é uma coisa muito séria. Esse é meu ponto de vista, não é a pura verdade. Mas se eu fosse uma pessoa que tivesse um poder de articular e fazer alguma coisa, eu faria nesse esquema. Eu não mudaria de jeito nenhum. Aí entram também as questões de empresa, que o pessoal tinha que participar mais da produção, saber o lucro, saber como este sendo investido o dinheiro, saber quais são as diretrizes. Se você é um empresário bem sucedido, vai poder lucrar tanto em cima do seu capital. Passou disso aí, esse montante será revertido para o Estado, para o bem de todos. Como você está gerando além daquilo que está previsto, você pode até gozar de algumas regalias pra incentivar a fazer mais disso, mas isso é muito complicado dentro do sistema. A última coisa que eu faria é incentivar o grande a crescer mais. Quanto maior fica, mais vai pisotear alguém.

Então eu continuo, Guilherme, filiado, até esse ano de 2006, ao PT. Não sei se vai pintar alguma coisa melhor. Se pintar algo que eu me identifique mais, com certeza vou retirar minha filiação, porque o partido não está correspondendo às minhas expectativas de jeito nenhum. Em termos gerais. Questão de saúde, educação, transporte, reforma agrária sem critério nenhum, distribuição de renda. Não apoio esse negócio que eu te falei, que eu comentei com alguns colegas, que se o "homem" for bom pros grandes, mas deixa uma parcela da ralé passando menos fome, eu não gosto de governo que dê esmola. O povo não precisa de esmola. O povo tem que passar por um processo de educação, ensiná-los a respeitar seus direitos, cumprir sues deveres, e ele mesmo produzir pra ele comer. Não é esse negócio de pegar esmola. Pra dar não sei quantos milhões de cestas básicas, que é o tal do 
Fome Zero, eи vou ter que tirar de algum lugar. Não existe uma árvore que produz esse negócio. Você vê as conseqüências disso aí nitidamente. Não é que sou totalmente contra. Pra quem está com fome tem que dar o que comer, sim. Mas cobrar dele a responsabilidade de produzir pra comer também. Não tem esse negócio de ficar dando esmola. Isso gera muito comodismo. Incentivar a escola, melhorar o sistema de saúde do pessoal. Existe uma infinidade de coisas pra serem feitas. É um grande desafio pra vocês que são jovens. A gente já está no fim da picada. Não me arrependo de nada que fiz até agora. Acho que o que pude contribuir, eu contribuí. E vou continuar contribuindo até quando eu viver. Ainda ontem à noite conversava com minha filha, quando eu vi aquela imensidade de peixe boiando por causa do esgoto, sujeira nas águas lá no Sul, falei: "Você é uma educadora. Vê o que você passa pros seus alunos pra não ficar chorando em cima do dia de amanhã. Porque alguém que fez isso, com certeza não teve um trabalho de conscientização quando ele estudou. Ou é um filha da puta muito grande mesmo. Ou alguém que está ao redor dele, por mais besta que seja, poderia perceber isso e denunciar. Não tem dinheiro que paga aquilo ali. Mas pelo menos punir. 'Você não vai fazer mais. Você não vai matar mais ninguém. Você vai ficar encostado agora. Você não está apto a viver na sociedade. Olha o que você fez. Matou todos os peixes, poluiu a água, ferrou tudo isso aí.' Isso passa muito pela área da educação”. Eu sempre converso com minha filha, que é pedagoga. Com esse outro que está fazendo matemática lá na USP, falo: "Teu campo vai ser de educar. Não é só ensinar número, não, cara. Educação é muito além do que se pensa”. [risos]

Então é basicamente, Guilherme, essas coisas a gente aprendeu no dia-a-dia. Não querendo justificar coisíssima nenhuma para o Sindicato, mas foi muito importante, porque o Sindicato me proporcionou aprender um pouco disso aí. A buscar conhecimento. Então, o sindicato e os movimentos populares, quando não tem uma pessoa ou um grupo pra fazer o rolo compressor, é a força maior. Eu diria que isso tem mais poder que nossa constituição. Quando você tem um povo bem organizado, você consegue quebrar até lei da Constituição Federal. Você consegue inverter esse quadro.

Essa semana participei de uma reunião na escola do meu neto, pois minha filha estava trabalhando. Fiquei horrorizado com essa instituição, o SESI. Meu, eles já fecharam vinte por cento da rede. E vão fechar muito mais. Inclusive, lamentavelmente, quem está na direção disso aí é o Jair Menegueli, presidente do SESI. Vai fechar uma infinidade, já fechou um monte. E a partir do ano que vem, vai começar a cobrar uma taxa elevada dos alunos. Eles não estão nem aí se podem pagar ou não podem. E a grande surpresa minha, ao participar dessa reunião, que não era uma reunião, você foi num auditório ouvir uma notícia, não abriram pra nenhum debate. Simplesmente veio lá: "Eu sou a diretora...” Aliás, "estou representando a diretora, que ela foi embora, e vai ter essas mudanças assim, assim e assim, A partir do ano que vem vão ser tantas horas de aula por dia. E os alunos que estão não têm mais direita a isso ou aquilo. Comunidade não vai participar mais. Quem tem direito a isenção disso é filho de funcionário. Prioridade pro filho de quem está na indústria, pagando essa taxa. Pronto. Quem vai estudar aqui, vai reduzir mais ou menos a setenta por cento, que vai ser a base do vestibulinho”. E você sabe como essas coisas rolam. Se eu sou grande lá dentro, entra a questão do rolo compressor também. Filho do meu amigo passou. O outro que passou, sobrou. Então, eu vejo com muita preocupação o futuro. O sucateamento das coisas públicas, vejo com muita preocupação. Eu acho que esse pessoal novo vai ter que mudar 
muito o comportamento, o modo de pensar, pra dar uma reviravolta. Não dá pra continuar do jeito que está. É muito complicada a situação. As coisas, comecei a aprender no sindicato, e lógico, que correndo aí atrás, perdendo noites de sono, fazendo cursinho aqui, perdendo finais de semana... perdendo entre aspas, pra mim foi um grande proveito, participar de uma palestra aqui, uma palestra á, um cursinho aqui, outro cursinho ali. Participando dos movimentos no bairro, buscando a melhoria do bairro. Como na fábrica a gente fez, como nos bairros a gente faz. Hoje mesmo você viu, acabei te prejudicando. Você ficou mais de quarenta minutos sentado esperando, porque eu estava participando de uma reunião muito complicada. As velhinhas já no final da picada vão participar da reunião. Não tem muito o que fazer mais. Tem que buscar um pessoal mais jovem pra impor essas questões.

Eu gostaria de fazer mais uma pergunta sobre o Sindicato. Você lembra dos boletins do Sindicato? Que tipo de publicação era?

Ah, sim. A gente lembra bem disso aí. Quando foi criada a Tribuna Metalúrgica, se criou a gráfica. Tinha o Henfil, que escrevia umas mensagens. Ele mandava umas caricaturas nas tribunas. E vinha um monte de denúncia. Saía uma vez por semana a carta do João Ferrador. Foi apelidado de João Ferrador porque quando você fala "companheiro", ou "camarada", ficava muito fácil pra polícia identificar. Então, não sei hoje, mas se usar essas expressões perto dos mais antigos, eles o identificam na hora. Agora, essa tropa mais nova, não sei qual é a formação. Hoje pra você se identificar como petista, se chegar em um lugar e chamar alguém de companheiro, recebe o rótulo na cara: petista. Camarada, comunista.

Agora, a questão da Tribuna, ela sempre era divulgada. As questões mais localizadas, dando mais destaque a aqueles lugares mais problemáticos. A Volks sempre foi o prato cheio pra sair na Tribuna. Essas outras firmas grandes. A Mercedes, a Scania. Tinha alguma restrição devido a esses grupos que havia lá. O rolo compressor passava em cima, então eles não faziam muita questão de divulgar os resultados. O filé deles era a Ford e a Volks. Era o filé pra mostrar as vantagens do avanço sindicalista. E essa carta do João Ferrador, como eu te disse, foi mais na época dos militares mesmo. Semanalmente publicavam esse artigo, dirigido ao presidente da República, que era o João Baptista Figueiredo. Isso a gente pode levantar, porque eu tenho o livro. João Ferrador era o bilhete que ele mandava. Era interessante, todo mundo lia isso. A gente tinha que andar escondido com isso na fábrica, porque os guardas já eram orientados pra ver quem trazia a Tribuna pra dedar. Isso antes de ter um local pra colocar a Tribuna. Depois de muita negociação criou-se um lugar pra colocar a Tribuna Metalúrgica. Aí os guardas tinham um papel fundamental: ficar de olho em quem pegava mais, que sabia que se ele pegasse mais, ele distribuía dentro da fábrica. Às vezes a Tribuna chegava depois das seis e meia. O pessoal que chegou às cinco ou às seis, já não tinha acesso. Então o que a gente fazia? Quem entrava às sete, já estava sabendo que o pessoal que entrou mais cedo não tinha... principalmente algumas notícias que a gente julgava importante, já levava pra eles. Eu tinha por hábito pegar por dia logo dez ou quinze exemplares, porque eu já tinha os pontos pra passar na fábrica e distribuir. Já deixava três ou quatro com um, que eu sabia que ele já distribuía pra outro. Não dava pra quem jogava no lixo. Dava pra quem lia realmente, pra depois a gente até refletir sobre o assunto.

Mas chegou uma época, que inclusive eu mandei umas mensagens... infelizmente eu não protocolei isso, eu não tenho como provar isso pra você hoje. Andei mandando algumas 
mensagens pro Sindicato pra que nos respeitassem um pouco mais. A Tribuna era pra divulgar as nossas notícias, os acontecimentos da classe dos operários, e não pra estar a serviço de partido político. Chegou um certo tempo que ela começou a divulgar muito a questão partidária. Mais na linha de interesse da direção. Destacava mais uma candidatura, principalmente dos candidatos proporcionais. Vereadores e companhia limitada. É injusto. Até quando eu escrevi pra eles lá, eu disse: "Se é pra divulgar candidatura, tira de um só partido, divulga todos. Porque tem muito trabalhador que não é petista. E é gente boa. E às vezes é até candidato por outro partido". "Pede pra que procure o partido dele", a resposta era essa. Então ficou uma coisa muito complicada no meu ponto de vista. Ficou difícil pra gente estar até acompanhando, opinando. Não faltava subsídio, mas eles pegaram uma mania do Estadão e outros aí, que era mais fácil contar piadinha, mostrar resultado de loteria, mostrar resultado de partida de futebol, e esses tipos de coisa. Eu falava: "Pra isso já tem a imprensa falada, já tem imprensa patronal. Vamos divulgar assunto que nos interessa. Já que tem esse espaço vazio, e vocês não estão conseguindo escrever tanto, coloca artigo educativo. História, artigo educativo".

Muita coisa, Guilherme, contraria a gente. A gente só não abandona tudo por ter aquela convicção que pode mudar. No meio de tanta coisa que a gente acabou falando, tem coisas importantes de você saber, se não sabe é importante ficar sabendo. Qual é a nossa bandeira principal? A gente não poderia de forma nenhuma estar terceirizando serviços dentro de fábrica. A terceirização de serviços pra nós foi um fracasso total. Fracasso operário. Buscando um pouco lá pra trás, falando de anos 70, 80, 90, isso veio a acontecer numa velocidade maior nos anos 90. Até então, desde o porteiro, até a última pessoa que trabalhava na empresa do ramo, era metalúrgico. Todo mundo votava, participava e gozava dos mesmos direitos. O que aconteceu? O volume ficou muito grande, eles começaram a fazer sacanagem. "Vamos terceirizar portaria. Vamos terceirizar serviço médico”. Então o médico que trabalha dentro da indústria prestando serviço não tinha nada a ver com a gente. Se tem uma greve, ele entra. O guarda, se tem uma greve, ele entra. Não tem nada a ver o prestador de serviço de empresa com a categoria. Ele entra. E assim foi privatizando [terceirizando] e a gente foi malhando isso direto. Rapaz, tamanha surpresa da gente! Sabe quem terceirizou um monte de coisa? O próprio Sindicato. Você vai lá hoje na sub-sede que tem em Diadema, você vai na sede central em São Bernardo, você chega lá, a portaria é terceirizada. O setor de biblioteca, que era nosso, foi terceirizado. O serviço de limpeza foi terceirizado. Mais grave, o serviço de formação, escola, foi terceirizado dentro do Sindicato. Eu fui fazer um cursinho lá uma vez, mais pra conhecer como estavam essas coisas lá, que houve algumas denúncias. Meu, era um curso de matemática básica pra você fazer depois na área de eletricidade. Pra mim, eu já tinha meu diploma de eletricista, já tinha dois cursos de eletricista. Eu falei: "Estou com tempo pra participar, e é perto, são três vezes por semana, eu vou fazer esse curso”. Fui fazer. E no primeiro dia em que a professora foi se apresentar, ela foi taxativa. Acho que foi até um pouco de coerência dela. Ela falou: "Olha, eu não sou funcionária do Sindicato. Eu sou funcionária do SENAI. Estou dando aula aqui pra vocês através de um convênio que a entidade de vocês fez com o SENAI. Portanto, não quero ver buxixo de metalúrgico aqui dentro. Seus problemas vocês discutem quando vocês quiserem, menos no horário de aula. Eu vim aqui pra dar matemática pra vocês, então vou responder de matemática pra vocês, e não vou permitir conversas paralelas de fábrica A ou fábrica $B$, 
diretor $D$ ou diretor $C$. Não quero saber disso. Eu vim aqui para ensinar matemática pra vocês. Mais nada do que isso. Agora, vocês vão ter um dia na semana que vocês podem, se a pessoa que vai fazer isso pra vocês deixar". O sindicato pegava uma parte que era OSPB, que eles davam uma vez por semana. Eles tinham lá um critério também que o cara poderia faltar em até cinqüenta por cento das aulas do OSPB e não sofrer penalidade nenhuma. Se deixasse de freqüentar cinqüenta por cento, ele ficava impedido de fazer outro curso mais pra frente. O pessoal ia uma vez ou outra. Discutiam mais aquela questão da raça negra. Mas não avançava muito, não. Falei: "Putz grila! Olha a que ponto chegamos. Se nós batemos contra a terceirização, por que nós terceirizamos o sindicato?” Foi muito complicado isso. Ainda bem que a gente retomou o assunto, que eu tinha esquecido de falar desse processo dentro do Sindicato. A coisa que mais me chateou foi isso, rapaz. A gente tem gente boa pra dar aula. Poderia dar aula até de graça. Agora só a questão da legalização do SENAI que tem o aval do MEC pra dar um diploma. Também não sei o que a gente poderia fazer. Mas achei uma incoerência incalculável. Você bate contra uma coisa e faz isso. É muito complicado. Como vai ser a partir de agora... E eu pretendo até acompanhar um pouco, mais através da Associação dos Metalúrgicos Aposentados. Não tenho a ilusão de fazer muita coisa, não. Eu já sei até qual é o pessoal que está lá, como age, essa coisa toda. É mais pra administrar plano de convênio médico, colônia de férias. Também, pro pessoal que já está aposentado, não sei como investir muito. Quem fez, fez. Quem não fez, aposto que não vai fazer. [risos]

\subsubsection{Parte 4}

Bom, Adão, vamos falar das greves. Antes da greve de 78, você lembra como era o clima dentro das fábricas? Já se falava em greve?

Já. Em 77 já se começava a falar em possibilidade de greve. Se fosse necessário, se faria greve, sim. Quando esgotassem os recursos, teria que se fazer greve, sim. Isso em 77. Aí, parece que a direção da empresa, o pessoal que controlava a situação, não acreditava nisso de forma nenhuma. Mesmo porque o regime ainda estava forte. Eles não acreditavam muito nisso, não. Só que essas coisas eram comentadas sigilosamente. Todo mundo, apesar de os trabalhadores daquela época não terem vivido esta experiência, já sabia o que poderia acontecer se o pessoal tomasse conhecimento disso. Além do risco de perder emprego, perseguição dentro da empresa, e até ser enquadrado como um desordeiro. Poderia ser preso ou coisa parecida. Você sabe disso. Isso em 77. Em 78, já começou a [inaudível]. Não teve jeito. Dentro disso que eu estava colocando, ao duvidar da organização, ou seja, da força do trabalhador, isso acabou levando a gente a algumas greves. Era uma coisa bastante complicada na época. Você imagina que dentro de um regime autoritário, não mediam esforços nenhum pra manter a ordem dos poderosos, imagina o que era discutir greve nessa época. Não era fácil. Mas eles já começaram a pegar um certo medo, ou pensar um pouco mais com as discussões do Lula. Durante o processo da eleição dele em 76, ele já tinha 
colocado essa proposta de como seria o Sindicato. E se fosse necessário, indiretamente ele já dizia isso, a gente ou teria que fazer greve - só que ele falava em outras palavras - ou a gente fecha esse sindicato pra não ficar tirando dinheiro do trabalhador, ou o coloca a seu serviço. Isso a gente entendia que tinha que fazer o movimento, e o Sindicato estaria dando o respaldo.

Nessa questão da greve de 78, no meu ponto de vista, foi mais um treinamento da categoria, e deveria ser um treinamento e uma ousadia. Essas coisas eram encaradas como um desafio à ordem e ao progresso. Em nome da ordem e do progresso, éramos encarados como desordeiros. Então não era à toa que os líderes eram presos. Eram presos e tomavam destinos que até hoje a gente não sabe. Isso foi no ano de 78. E quando aconteciam essas greves em 78, ela não acontecia em firmas pequenas. Ela acontecia em firmas com poder de fogo maior pra se organizar. São as montadoras. Scania e Mercedes, pra mim foram pioneiras nesse assunto, em seguida vieram a Volks e a Ford. Nessas alturas a Volks já tinha engolido todas as outras empresas. É um pouco fora do assunto, mas não sei se você sabe disso, ela foi engolindo as outras empresas pra tomar conta do mercado. Eles chegavam, compravam e desativavam o ferramental todo deles pra não ter competição. A coisa era desse jeito. E dentro desses desafios, aonde aconteciam essas perseguições, pra gente foi um treinamento e uma demonstração para os grandões que a coisa não estava totalmente controlada, não. A miséria já ia espremendo o pessoal e eles iam ter que fazer essa greve mesmo. E com a postura deles mediante essas greves, gerou uma indignação tão grande nossa, dos trabalhadores, que aí o bicho pegou feio mesmo em 79, 80, 81 e 82. Esses quatro anos foram anos pesados mesmo pra nós, a nível de greve. Foi muito complicado. Em 77 foi basicamente isso aí. 77, 78, e aí a coisa começou a alavancar mesmo. Em 78, as greves já aconteciam, não só pela carestia. Nosso salário estava muito defasado em relação aos gêneros de primeira necessidade, aluguel e outras coisas. As condições de trabalho eram péssimas. A falta de respeito com o trabalhador era muito grande. Cada vez ia indignando mais. A gente costumava usar o vocabulário: inflamando, inflamando. Você imagina uma fogueira, e iam jogando mais combustível. Todas as ações autoritárias que eles tomavam, mesmo a gente não tendo a liberdade de se organizar devido ao regime, gerava muita indignação. Inflamava muito a gente. Cada um que era perseguido, despedido do emprego, apanhava da polícia, ou coisas perecidas, parece que era mais um volume de combustível que jogavam na fogueira. E a coisa foi se alastrando desse jeito.

Até que no ano de 79 o bicho já pegou mais feio. Bastante gente foi presa, e a intervenção era imediata da polícia. Decretou greve, batiam um fio, e a tropa de choque estava ali todinha, como se a gente fosse um bando de bandido. Isso ocorreu durante o ano todo, e eles fecharam o ano com uma sacanagem muito grande, que gostaria até de estar lembrando da morte do metalúrgico Santo Dias da Silva, que se completa agora 26 anos. Foi baleado pelas costas pelo soldado Herculano, na porta da empresa Sylvania em Santo Amaro. Ele era uma pessoa muito ponderada, muito consciente. Era querido por todo mundo, no lugar onde ele trabalhava, no lugar onde ele morava. A gente sabia que ele tinha uma ligação muito grande com a Igreja Católica, ajudava com essa coisa da evangelização, onde entra a formação. E nesse dia 30 de outubro de 1979, uma greve já bem inflamada na Sylvania, e estava pra acontecer. Porque a polícia estava de um lado, o pessoal já não estava agüentando do outro, e em um determinado momento, quando o Santo Dias levantou a mão 
pra sinalizar aos grevistas pra pedir calma, a tropa da Polícia Militar que estava atrás tirou a vida dele. Atirou pelas costas. E deu um trabalho. Como eu falei que sumia muita gente, com o Santo Dias não foi diferente. Logo que o soldado Herculano executou o serviço... lógico que não se poderia atribuir somente a ele, é um coletivo que estava ali, era uma tropa, e alguém estava comandando. Alguém tinha que atirar, e esse alguém foi o soldado Herculano, e não podemos esquecer esse nome de forma nenhuma, porque ele tirou estupidamente a vida de um militante. De repente chegou aquele tumulto de polícia, não deixaram os funcionários se aproximarem da vítima, ali já o jogaram em uma viatura. Ninguém sabia pra onde o haviam lavado, ninguém tinha notícia de nada. Sumiu. Olha que deu um trabalho danado pra localizar o corpo. Com a liderança da Igreja Católica na época, ajudaram muito no resgate do corpo do Santo Dias. Foi o D. Paulo Evaristo Arns, que hoje está doente, ele comandou certo tempo a igreja de São Paulo, e através de alguns advogados, mais voltados pros direitos humanos, conseguiu localizar o corpo do Santo Dias e realizar o enterro. Não é exatamente isso que você me perguntou, mas como eu entrei no assunto, eu encerro. Completou agora 26 anos, e todo dia 30 de outubro, no mesmo horário, que foi às duas e pouco da tarde, ainda se reúne um pessoal no local do assassinato dele e cada um manifesta sua solidariedade da sua própria maneira. Nada é imposto pra ninguém. A família dele a gente sempre tem contato, a Dona Ana Dias, a filha e as três netinhas. Sábado ainda estive com eles. Então a coisa pegava feio mesmo.

E aí, prosseguindo, essas questões de greve, como eu estava falando desse companheiro que era da Sylvania, que não era uma firma tão grande, em comparação com as montadoras, essa coisa pipocou em várias firmas. Lógico, toda a categoria sofria do mesmo modo. As perseguições no local de trabalho pelas chefias, as condições que você tinha, a jornada excessiva, máquinas péssimas, não existia nada de dispositivo de lei pra te amparar. A própria CIPA era feita pra inglês ver. $O$ cara nomeava um pessoal, fazia a ata do jeito que ele queria e tocava pra frente. A maioria dessas firmas não tinha técnico de segurança. Se não tinha técnico, menos ainda engenheiro de segurança. As ferramentas eram construídas e as operações eram feitas baseadas na experiência do pessoal que adquiria de acordo com a necessidade de cada serviço. Tinha uma criatividade muito grande por parte dos trabalhadores pra gerara meios pra manusear, pra trabalhar. Infelizmente, todo acidente que acontecia era encarado como um ato inseguro. Não tenho medo nenhum de afirmar que cem por cento dos acidentes eram causados por condições inseguras. Havia umas prensas de corte, de repuxo. $O$ cara, no cansaço, com aquela quantidade de horas trabalhando, a mão do cara já ia embora. Não tinha dispositivo nenhum de segurança. Nada, nada. A cabeça do cara que funcionava tudo aquilo ali. Disparou uma chave elétrica, uma chave cíclica pra girar o eixo epicêntrico, deixa que o pau come. E a cabeça do cara? Você imagina o cara trabalhando a quantidade de horas que trabalhava, até doze horas por dia. Lógico que não eram todas horas normais, entravam as horas extras. Hora extra existia por alguns motivos: ou você fazia hora extra, ou estava convidado a sair do emprego, porque tinha mais gente pra suprir seu lugar. Por outro lado, salário baixo. Infelizmente a gente fazia isso: "Se eu trabalhar duas horas a mais, já vai ajudar no meu salário”. O percentual que eles pagavam não era o mesmo de hoje. Não tinha uma lei que determinava isso. Hoje, sim. Hoje existe isso. Através dessas lutas se conseguiu avançar, hoje tem a CLT, as convenções coletivas. $O$ limite de hora extra, os valores a serem pagos. Se é na seqüência das suas horas de trabalho 
é um valor, aos sábados já é outro, domingos e feriados já é um outro valor. Hoje, acho que fazer hora extra é estupidez. O cara está se suicidando, e ainda criando um suicídio coletivo, tirando a vez de outros trabalharem .

Pra combater isso, essas questões de máquinas inseguras, o equipamento totalmente inseguro, perseguições, salário super achatado, a questão de higiene, a gente não tinha outro mecanismo a não ser greve. Porque não tinha diálogo. Nessa época não tinha como dialogar de forma nenhuma. O patrão, os "homi”, ele falou, está falado e acabou. Como os caras são muito criativos na época que não tinha nada automatizado. Não tinha... como se diz? Técnico, não tinha pessoas formadas. Essa mesma criatividade que tinha pra gerar recursos pra produzir, pra trabalhar, apareceu num momento muito importante, ao meu ver, foi na época de organizar as greves. Olha, Guilherme, é impressionante como esse pessoal tinha criatividade pra organizar. Lógico, eu já comentei com você em outros momentos, que a gente não tinha liberdade de fazer reunião, de distribuir panfletos nem coisa nenhuma. Já comentei como se dava esse processo. Mas na organização da greve a coisa era rapidinha. Se espalhava isso dentro de vários setores, e o pessoal tinha uma criatividade muito grande. Em cima das perseguições, foram obrigados a ter essa criatividade. Não sei se você conhece fábrica. Imagina o início de uma linha de produção. Como é que fica? Os caras têm uma facilidade muito grande de saber quem é que parou primeiro. Porque tem o cara que abastece a linha, tem o meio de linha, que é o meio de campo, e tem o final. Aonde congestionou mais peças, estão sabendo que é aquele que parou. Existia essa organização que quando parava, era como se desligasse o interruptor. Pá! Parou tudo de uma vez. Então não tinha cabeça. Os caras ficavam loucos. Por isso que até saiu o nome de uma greve, a vaca louca. O patrão, o chefão, ficava feito louco pra procurar. Eles davam aquelas investidas pra saber quem, de onde originou, quem parou primeiro, quem deu a idéia, essa coisa toda. Ninguém entregava ninguém, não. "Bom, parou. Se todo mundo parou, como é que eu vou trabalhar sozinho?" E assim ia. Achava super importante a maneira como aconteciam as coisas nesse processo de greve.

Com cada criatividade que nós tínhamos na época, não podia aplicar outras vezes. Se acontecia uma vez ou duas, fica tranqüilo que os observadores, o patrão já montava uma equipe, quando havia suspeita de algum movimento, já havia uma equipe pra ficar de olho o tempo todo. Não só a linha, o local de trabalho, mas ficava de ouvido em pé no banheiro, na hora do almoço. Café, naquela época, só firma grandona que tinha. O carrinho passava no meio do corredor, o cara pegava um copo, não tinha nem como trocar idéia, era um barulhão desgraçado. Mas mesmo assim eles ficavam de olho no horário de entrada, no intervalo de almoço. No boteco. Quando tinha boteco por perto, esse era um prato cheio pra descobrirem quem organizava. Tudo isso a gente teve que imaginar na época, e cercar essas variáveis pra não deixar mais gente sofrer sozinha as conseqüências. $O$ sofrimento já estava ali. Não era o fato de mandar um embora ou dois, que ia gerar sofrimento. Ia castigar aquele, ia pagar bem mais caro. Mas o sofrimento já estava pra todo mundo, nessa situação que acabei de falar. Aí tínhamos que montar nossos esquemas também, pra não deixar os companheiros entrar em papo furado. A gente já sabia que eles mapeavam, pegavam gente de fora pra trabalhar. $O$ cara chegava se identificando como participante de movimento de sindicato, não era porcaria nenhuma. Era um puta de um dedo-duro que estava ali pra fazer espionagem mesmo. Então tinha que ficar esperto. Até hoje eu tenho essa concepção comigo. Alguns 
movimentos que eu participo, movimento popular, não fico dando murro em ponte de faca. Não dá pra falar a torto e a direito. Não sei quem está ouvindo, quais são as intenções do cara.

Nessas vivências de greve foi uma grande escola, foi onde a gente foi aprendendo. Chegou uma hora que até foi elaborado subsídio pra ser estudado. O pessoal treinar. Esse treinamento você tinha que fazer. Lógico que você não ia fazer isso por parte da fábrica. Como se fazia? As associações, as ONGs, nas periferias, tiveram um papel fundamental pra ajudar nas greves. Uma pequena parcela da Igreja Católica contribuiu muito. Cedia espaço. Não vou falar de igrejas evangélicas, porque naquela época quase não existia. Católica dominava praticamente tudo. Inclusive esse cardeal aqui de São Paulo, D. Cláudio, que foi nomeado pra ser o prefeito de Roma na semana passada, é um amigão do Lula. Sempre batiam papo. Ele tinha um cargo alto na Igreja em Santo André. Ajudou bastante nessa parte. Depois ele se bandeou pra outro lado, conseguiu os objetivos dele. Hoje é prefeito em Roma. Semana passada ele foi convocado e foi pra lá. Vamos ver o que vem por aí. Mas indiferente disso, mudou toda a conjuntura, e nós temos que nos organizar.

Aí, falando desses acontecimentos de 79, nós tivemos que avançar bastante em aperfeiçoamento de greve. Sem fazer esses treinamentos, essas palestras, esse material que o pessoal leu... ou deu pra alguém ler, porque a maioria na época não sabia ler. Hoje mudouse o quadro. Tem analfabeto, mas não na mesma dimensão. Naquela época era uma infinidade de gente que não sabia ler nada. Alguém lia, e as pessoas prestavam muita atenção. Nós temos entidades aqui, inclusive eu faço parte da direção de uma delas, que teve papel fundamental nisso aí. Isso era feito aos domingos. Não precisava nem fazer hora extra. Aos domingos a gente ia pra lá. Tinha alguém que já tinha estudado um pouco, já tinha avançado, e mostrava pra gente a relação capital e trabalho. Foi quando a gente começou a aprender esse troço aí. Como se dava a relação capital e trabalho, ou seja, a mais-valia. A alta produção, o cansaço do cara, como a empresa lucrava. Isso começou a ser estudado e passado para os operários. Foi fundamental pra abrir a cabeça pra ter uma greve mais organizada. Por isso que a greve de 80 já foi mais organizada. Se tornava quase impossível as empresas e a polícia saber quem era quem. Nessa daí, eu não tenho dúvida nenhuma, que muita gente inocente, principalmente os que não gostavam muito de participar de uma reunião no Sindicato, nas comunidades de base, as associações... esses que faziam esse treinamento já estavam um pouco mais livre de sofrer as penalidades porque já sabiam como agir numa greve. Agora esse que não queria nem saber era o primeiro que levava pau. Ele se expunha. Vamos supor que nós dois estávamos lá. Por mais que a gente seja amigo, naquele momento ali, do corpo a corpo, depois que você está não mão da polícia, de corpo a corpo, a não ser que eu fale: "Morre nós dois". E o resto? Muito confuso esse troço. Pra gente foi bastante confuso nessa parte. Até se atingir uma grande parcela. E aí foi onde começaram a surgir essas reuniões de sindicato, palestras.

E aí surgiram as idéias de fazer as negociações. A gente não deixou que ficassem pra fazer as negociações só o Sindicato e a direção da empresa. O medo da classe dominante aumentou com nossa organização. Eles são muito inteligentes. Já começaram logo a negociar. Nós estamos falando do ABC. São Paulo é outra história. Eles cooptaram os dirigentes do Sindicato, então, infelizmente, era mais um braço que a empresa tinha pra se fortalecer. Tinha, não. Tem até hoje. O Sindicato dos Metalúrgicos de São Paulo eu enxergo 
como um braço que as empresas têm pra se sustentarem. Deve haver umas trocas de favores ali. Eu não posso te dizer com propriedade que eu não participei em São Paulo, participei mais no ABC. E eles tentaram fazer isso no ABC também. Lá não foram bem sucedidos. Há informações, que sabendo das péssimas condições de vida que o Lula tinha, a Volks comprou um apartamento, mobiliou, pôs um carro, parece que um Fusca, na garagem. Mandou representante e falou: "Lula, isso aqui é seu. Pra você não se meter mais nesse negocio aí. Deixa agora pros outros presidentes". Eles acharam que era o Lula que resolvia tudo. Grande engano. Àquelas alturas do campeonato, o Lula era um medalhão, mas no resto já tinha surgido liderança pra caramba. Como eu te disso, lá em 30 de outubro de 79, um deles tinha sido assassinado publicamente. Nessa parte foi uma burrice deles. Eu não presenciei. Isso foi o que eu ouvi. O Lula reagiu da seguinte forma com quem fez essa oferta: "Diga pra Globo que vocês têm doze horas pra retirar toda essa proposta, senão eu vou tornar isso público. Eu vou mandar pra todos os lugares. Se no Brasil isso não for aceito, vou tentar denunciar isso na matriz, lá na Alemanha. Eu não me vendo por dinheiro nenhum, porque também sou um operário. Isso é uma sacanagem. Fala pra ela que é melhor tentar oferecer melhores condições de vida e de trabalho, que vai gerar vida, e de segurança, do que me comprar. E esse pessoal que está junto comigo jamais vai se vender”. Eu não presenciei o Lula falando isso, eu não estava durante esse acontecimento. Mas colegas que trabalhavam comigo presenciaram esse fato. Pra mim, isso não é mentira, porque eu confio muito nas pessoas que presenciaram isso. E foi muito terrivel a questão dessas greves.

Eu falei mais do geral pra você, do ABC, e mesmo dentro da empresa a gente só tinha acesso a essas informações nas reuniões do Sindicato, nas grandes assembléias. Como lá no início a gente começou a falar desse processo, os patrões ficaram espertos, perceberam que nossa organização tentava fazer a negociação, então surgiu a proposta. Nas negociações acontecia o seguinte: pode-se criar uma comissão, e seria ingenuidade nossa pôr mil pessoas pra negociar com o diretor. Não é assim, não dá. Então você teria que eleger de um total de funcionários que tinha ali quem se envolvia mais com o assunto, pra negociar em nome da categoria. E nas negociações feitas lá, esses companheiros não tinham autoridade, nós não demos autoridade pra eles, de definir nada com a direção de empresa nenhuma. Seja em casos isolados, ou em coisas mais ampliadas via FIESP, nós não demos autonomia nenhum de eles tomarem decisões. Como faria? Mediante os acontecimentos, eles já tinham uma pauta de reivindicações. Então sentavam à mesa com a direção da empresa e ia negociar. Tinha coisa que a empresa aceitava negociar, tinha coisas que a empresa aceitava até ceder, e tinha coisas que eles falavam: "Não, isso não se discute, eu não dou e acabou”. Bom, então se chamava uma assembléia, e essa pessoa, ou um diretor do Sindicato, vinha apresentar as propostas. Não dá pra gente negar isso, que quando alguém apresentava uma proposta, às vezes ele inflamava mais a coisa, ou amaciava um pouco mais. Ficava muito evidente pra gente essa ciosa toda. Principalmente pras pessoas que tinham uma participação mais ativa. Ou seja, já nasciam aí as manobras. A gente percebia. E aí a assembléia decidia se a gente aceitava ou não. Se não aceitasse, levava à votação a continuidade da greve. Ou a suspensão temporária. Como vai ficar suspendendo greve pra negociar? Porque, pôxa, quantos anos perdemos? Tinha que forçar a barra, inclusive ser o mais rápido possível. Quando os caras viam as máquinas funcionando, pra eles era uma tranqüilidade. A maioria das vezes a gente optava por dar continuidade à greve. Era uma forma de você forçar uma negociação mais 
rápida. Caso contrário, era muita enrolação. O cara ia lá, tirava um pouco de atraso da produção dele.

Aí sem estar contando ainda a intervenção da polícia. Porque parecia que as dependências das empresas estavam cheias de marginais. Você via policial desfilando nos corredores o dia todo. Muitas vezes até com arma na mão. A gente olhava aquilo e falava: "Mas que negócio é esse? O cara trabalhando, do trabalho nosso que sai o salário desses caras, que compra essa arma, e o cara aqui desfilando!”. Tirava toda a liberdade nossa. Nem olhar um pro outro não podia. Qualquer coisa ele já te enquadrava. O pessoal da polícia que estava ali dentro, fardado ou camuflado, tinha total autonomia pelo lado da empresa pra fazer o que muito bem queria. Poderia simplesmente chegar lá e falar: "Desliga a máquina que você está preso”. E aí? Ia preso e acabou. Não tinha muita conversa. Eles faziam relatório lá da maneira que eles achavam melhor pra eles, de acordo com os interesses deles. Então a coisa foi tomando esse pé.

E aí, com essas intimidações, essas repressões todas que houve nessas greves, a gente já não pôde fazer coisas conjuntas. Surgiu a necessidade então de você fazer coisas isoladamente em cada fábrica da categoria. Faziam seus movimentos, criavam seus líderes naqueles lugares. Lógico que era negociado com o Sindicato. A gente nunca deixou de legitimar o Sindicato, porque a gente entendia que era de suma importância a gente ter um sindicato que representasse a gente. Faziam essas negociações, e aí que o pau comia direito, rapaz. Quando se fazia greve em um local isolado, digamos assim que um bairro tem cinco ou seis fábricas. Aí vocêfez greve em uma fábrica, e as outras estão trabalhando, pra polícia era um prato cheio, porque ela ia atacar só ali. O pau comia solto mesmo. Então a gente teve aquelas greves longas em algumas firmas. Aí ocorria um monte de prisões. Eu me lembro, inclusive, na minha unidade... Não só me lembro, eu participei, eu tenho muito que lembrar. A gente que participou de tudo isso aí, não dava pra esquecer de forma nenhuma. Tivemos que fazer umas paradas de muitos dias na unidade que eu trabalhava, na época com o nome de Metalúrgica Rossi. Mudava toda hora de nome, nessa época era Metalúrgica Rossi. Ela foi de São Paulo pra lá. O bairro estava crescendo e ela não podia ficar em um bairro residencial. E lá, rapaz, quando se organizou, e a gente viu que estava perdendo muito pras outras firmas, em termos de organização e salário, quer dizer, condições de trabalho $e$ salário. Desde uniforme, alimentação, café, convênio médico, que a gente não tinha. Papel higiênico, que não tinha. Água, não vou nem falar de água gelada, nem água filtrada não tinha. Do jeito que vinha da rua, você bebia da torneira. Se está quente, bebe quente. Se está fria, bebe fria. Papel higiênico, cada um se virava da maneira que podia. Então a coisa foi bastante complicada.

Um ponto positivo, daquela época pra agora, é que não tinha terceirização. Naquela época, desde o guarda, até o engenheiro, eram todos de uma categoria só, eram todos metalúrgicos. Na hora da briga todo mundo era metalúrgico. Muito embora o pessoal do escritório sempre pelegou. Nas firmas pequenas, sempre pelegou. Eles não faziam parte da greve de forma nenhuma. Tinham alguns que diziam ainda: "Deixem que esses trouxas lutem. Se sair aumento, sai pra todo mundo”. A gente achava um ato covarde, mas tinha que respeitar, vai fazer o quê?

Então a repressão do polícia era bastante complicada. Chegava a ser um ponto, que digamos assim, não era nem o próprio comando da polícia que estava mandando a 
corporação pra lá. A firma já mandava. A coisa começou a ficar tão grande, que não tinha como eles policiarem tudo. O que as firmas faziam? Começaram a contratar os policiais pra prestar serviço fora do expediente de trabalho. Só que eles iam com a farda, com a arma, e às vezes até drogados. Porque se ele já tinha trabalhado o período todo na rua, e iam fazer aquele bico, a maioria das vezes dava pra perceber que esses caras estavam drogados, pelo comportamento deles. E aí até cito um exemplo, na greve de 82, onde eu trabalhei. Ficaram lá quatro policiais uns quinze dias. Sempre os mesmos, nos nossos horários. Eles faziam bico lá, e trabalhavam na Ford, e da Ford já vinham direto. Tinham todas as mordomias, almoçavam lá, café, essa coisa toda. Sempre desfilando com os diretores. Até que chegou um determinado momento que as coisas foram esquentando, esquentando nas negociações. Aí, os patrões começaram a entender que aquilo era uma afronta a eles, que a gente estava desacatando as normas internas da empresa, desacatando as leis. O Sindicato não tinha perna pra acompanhar tudo isso, era muita coisa. Então, esse fato foi interessante. Quando ia ter um conflito, eles queriam mandar uma turma nossa embora. A gente não aceitou, e aqueles quatro policiais que estavam ali não davam nem pro cheiro. Foi quando eles mesmos solicitaram reforço. Daí a pouco chegaram uns dez ou quinze camburões. Na época era a ROTA, e outras tantas outras porcarias. Chegaram assim, e até hoje eles usam essas tática, chegaram naquela velocidade toda, dando aquelas freadas bruscas, sirenes acesas, e os caras já saem dali com arma na mão. Chegaram nessa quantidade, e o comandante deles, cheio de gracinha, "eu sou o bom”, mais ou menos nesse sentido. Foi chegando e chegou uma parte da tropa lá fora, e já entrou com uns cinco ou seis soldados o acompanhando. Foi direto no departamento de pessoal, no recursos humanos. Chegou e perguntou pro chefe de lá quem estava liderando aquela greve. Ele não teve dificuldade nenhuma, o chefe de recursos humanos. Apontou cinco companheiros nossos. Mostrou as fotos. Aí o comandante já saiu de lá, já deixou o pessoal dele de plantão ali, foi efetuar a prisão dentro da empresa. Três camburões entraram nas dependências, já abriram as portas traseiras, e ele procurando o pessoal pra prender. E prendeu. Prendeu cinco. Foi interessante isso, rapaz, um ponto muito interessante nessa unidade. Quando esses cinco companheiros foram presos, o pessoal circulou as viaturas. Acho que tinham três viaturas. Aquele tumulto de gente ao redor fechou as viaturas num círculo. Aí o motorista da viatura que estava na frente, que inclusive era a que estava com os cinco presos... uma cambada de filha da puta, colocaram três viaturas $e$ colocaram os cinco em uma viatura só. Não sei qual eram as intenções deles, mas não foram bem sucedidas, não. Meu, ele ligava aquilo, e sabe aquele balancinho que o cara faz no carro? Aquelas roncadas, com a sirene acesa. O outro guarda que estava no banco do passageiro, os dois com arma na mão, e ninguém afastou. E ele acelerando, e acendia farol, e a sirene tocando. O pessoal se inflamava mais ainda. [risos] Sabe o que acontece? Isso aí, rapaz, é até bonito, que foram as mulheres que fizeram isso. Elas chegaram na lateral do carro e levantaram o carro. O pneu girava em falso. [risos] Foi muito legal isso! Não consigo esquecer, o filme ficou gravado na minha mente. Foi super interessante. A maioria dos funcionários naquela época já eram mulheres. Achavam que os homens estavam ficando meio rebeldes, que a mulher é mais fácil. Caíram do burro. A mulherada levantou aquilo ali. A peãozada juntou naquilo ali, e aí trocavam, iam se revezando, rapidamente, pra ninguém ficar cansado. E aí a gente teve condições de negociar com os caras. E aí a gente já estava com nossa retaguarda também. Como eles tinham a retaguarda deles lá. Nesse momento o 
pessoal já se preveniu com pedras, pedaços de pau, se tivesse que ir pro pau, vai fazer o quê? Não iríamos só apanhar, íamos ter que revidar. Aí pra abaixar o carro, a viatura, a gente impôs uma condição: desliga o carro, desce e deixa a chave no contato. [risos] Mas foi uma coisa que, se tivessem treinado pra fazer, não sairia tão perfeito. Uma coisa improvisada que funcionou muito bem. Aí, o motorista engrossou: "Quem são vocês pra me dar ordem?" "Nós estamos pedindo. Você não quer descer? Então você vai ficar aí até a hora que você sentir vontade. Nós não estamos cansados de segurar o carro. Pode roçar motor, pode fazer o que você quiser". Com muito custo, desceu. O cara desceu. Desceram dois de um lado, dois de outro. Foi a conta de o cara descer, o pessoal fechou a porta do carro de uma vez, e a gente isolou a polícia do carro. Aí falamos: "Agora nós vamos negociar". "Mas negociar o quê? Vocês tem que negociar com a empresa!" "Não. Cinco companheiros estão aí dentro. Nenhum vai preso. Vocês não têm dignidade pra levar nosso pessoal preso. Vocês já mataram uma infinidade. Esses cinco aí vocês não vão matar, não. Se forem matar, vão ter que matar o resto." Eram 1.200 pessoas. "Pode mandar vir transporte da companhia de vocês pra levar todos nós, porque os cinco só não vão. Ou vocês liberam esses cinco, ou levam todo mundo". Aí foi aquele bafafá danado. Chegou o mais forte deles e acabou negociando. Aí chegou a imprensa. Aí a coisa já começou a complicar. De repente ele: "Então vamos fazer o seguinte: eu vou abrir a porta traseira," eles não falam chiqueirinho, o papo deles lá é outro, "os cinco infratores vão descer, e juntos, vocês vão tirar uma comissão pra responder pra nós o que vai rolar daqui pra frente”. Tudo bem. Aí já desceram os cinco. Aí não fomos pra dentro do carro, fomos pra uma sala negociar. [risos] Não foi ninguém preso nessa história. E nisso aí já se formou a comissão. Três dos que estavam presos, e mais dois, sem ser dos que estavam presos, pra dar continuidade à negociação. Primeiro item: a não presença de polícia. Principalmente durante o nosso período de trabalho. Aí nós falamos: "Tem quatro policiais que estavam aqui dentro. Nós queremos saber se foram mandados pela companhia. Porque se é, essa companhia está trabalhando de forma errada. Eles estão bêbados aqui dentro," a gente não falou maconhado, "levando risco de vida pra nós, andando entro da fábrica com arma na mão”. E aí, fomos só colocando as coisas pro comandante da polícia que estava lá. Ele chegou à conclusão que o grande infrator era a empresa. Voltou lá no recursos humanos, conversou com a gerência de lá, e já deu um toque de recolhida. Aqueles quatro que já estavam lá antes de ele chegar não eram do batalhão deles, então não tinham que receber ordens dele. Só que o cara era forte. Ele deu o toque de reunir o pessoal, se reuniram, e ordenaram: "Esse é um problema interno. Nem sei o que viemos fazer aqui. Estamos nos retirando. Só voltamos aqui se houver necessidade. Tem uma comissão, está escrito os nomes deles, são responsáveis por isso, aquilo e tal”. Quando ele alterou um item a mais lá, que qualquer conflito que houvesse lá, esses cinco seriam presos. Nós não garantimos, não. Falamos: "Nós não vamos provocar. Se houver provocação, vamos reagir à altura. Da nossa parte nós garantimos. Não haverá provocação, vamos manter a ordem aqui dentro, não vamos quebrar nada, vamos tomar água, vamos usar o banheiro, o refeitório. Ninguém vai ser desordeiro. Vamos continuar jogando nosso dominó, nosso baralho. A gente não vai aceitar ninguém bêbado aqui dentro, inclusive os policias que estão aí. Agora, se houver provocação pelo lado da empresa, ou pelo lado de qualquer chefe, vai ser respondido à altura”. Ficou nessa questão. O pessoal começou a ir embora. E aqueles quatro, estavam sendo bem pagos, se recusaram à ordem desse cara; "Não, nós não 
pertencemos a seu batalhão, e vamos permanecer". Ele falou: "Os quatro!" Eles chegaram lá, ele tirou um documento: "Vocês querem ir ou querem que eu levo?” [risos] Eles bateram continência na hora, meu. E aí a gente já falou: "Como você percebeu a intransigência, a gente pede até pra dar apoio, que a gente está correndo rico de vida". "Se vocês cumprirem o que vocês prometeram, não haverá mais intervenção”. Sabe o que aconteceu? No dia seguinte a gente foi trabalhar. Porque naquela tarde a gente conseguiu fazer o acordo. Foi só retirar a força bruta, e a gente conseguiu. A gente não deixou que os cinco companheiros fossem presos, não deixou a empresa fazer o que ela estava querendo fazer, conseguimos retirar os policiais de lá, e conseguimos negociar com a empresa. É lógico que essa comissão, inclusive dos cinco presos, dois foram compor a comissão, e mais dois escolhidos em assembléia, eles cederam um pouco. A gente já sabia que tinha que ceder um pouco. Nunca se consegue tudo que o quer. Você pede 100 pra conseguir pelo menos 50 ou 60, já está de bom tamanho. Não é que você abriu mão. Não. Você aceita isso e o resto fica pendente pra um outro momento. Era essa a tática que a gente usava. Isso foi uma coisa muito marcante pra mim na empresa, esse acontecimento. Super marcante. Então esse foi um dos momentos.

Numa outra greve, nessa unidade mesmo, uma greve que durou vinte e poucos dias, também com a presença da polícia, que chegava pra arrepiar, eu fiquei do lado de dentro da firma. Eu já havia sido promovido pra supervisor. A empresa percebeu o poder de fogo que a gente tinha, e a capacidade profissional. E como eu havia sido eleito pela CIPA, eu tinha estabilidade. E eles sabiam que o Sindicato não ia abrir mão pra eles me mandarem embora e me pagarem os meses que eu tinha direito de estabilidade. Eu tinha uns seis meses de mandato, eram dois anos de estabilidade, então eu tinha um ano e meio pela frente de salário garantido. E mesmo assim, eu não ia aceitar de forma nenhuma. Mesmo se o Sindicato acordasse com a empresa pra me mandar embora e me pagar os direitos previstos por lei, me pagar esses meses de estabilidade, jamais eu aceitaria. Inclusive eu já tinha até me programado pra uma greve de fome na porta da fábrica. Se isso viesse a acontecer eu iria fazer. Não ia abrir mão. Enquanto não fosse modificado, eu não voltaria atrás. Eu já tinha até conversado com algumas pessoas mais próximas: "Se isso acontecer, pode ser o meu fim, porque eu vou ficar na porta da fábrica e não vou sair, não. Só saio morto”. Só que o que aconteceu? Me promoveram pra supervisor. E um dos critérios pra supervisor é não participar da greve. E a nossa orientação mesmo, como funcionário, é de não confiar em supervisor. Não dá pra confiar mesmo. Supervisor é bicho safado. Inclusive eu aceitei o cargo de supervisão estrategicamente. Nessa greve aí, vou te contar, eu já estava como supervisor. Aconteceu essa greve, a firma mandou uma infinidade de gente embora. No décimo primeiro dia em diante, começou. A gente chegava de manhã e lá estava a listona dos caras que tinham que assinar o aviso prévio. Dispensados por justa causa ou coisa parecida. E eu, do lado de dentro. Nessa aí, eu comecei a participar das reuniões internas, que a direção da empresa fazia junto com representantes da polícia. Eu vou citar nomes, senão fica muito vazio. Eu poderia falar que alguém da manutenção, ou alguém da segurança. Eu prefiro citar nomes, porque eu não tenho medo de fazer isso. Os caras estão vivos, e se vierem me perguntar, eu vou falar: "Quer negar o que você falou, o que você fez?”. Então tinha o supervisor da manutenção, de nome Ivani. Ele se prontificou a ir à serra da carpintaria, e cortar os sarrafos pra polícia entrar que nem uns loucos. Os policiais falaram: 
"Está inflamado aí fora, o pessoal está pra invadir a qualquer hora, e a gente não sabe se vai agüentar isso sozinho. Então o que vocês vão fazer? Se tiver bastante pedaços de madeira aí, vamos colocar em alguns pontos, e na hora da invasão, todos que estão aqui pegam esses sarrafos e descem o pau. Vocês batem despreocupados. Se quebrar o osso, ou se matar, não são vocês, somos nós da polícia que fizemos". Aí esse Ivani falou: "Não temos essas madeiras, mas eu vou sarrafear as tábuas lá, vou cortar”. Ele sarrafeou um monte de pedaços de madeira. Sarrafos de madeiras de cinco por dois e meio, por um e vinte mais ou menos de comprimento, que era a medida certa pra descer o pau. E colocou em três pontos estratégicos, onde poderia acontecer a chegada do pessoal. Então já fomos orientados: "Se você ver que vão invadir por lá, já tem as madeiras ali. Mete o pau! Qualquer coisa, foi a polícia que fez”. Aí, Guilherme, que eu achei que foi muito importante meu papel em estar lá dentro. O que eu fazia? Se essa reunião acontecia na parte da manhã, no primeiro período e normalmente tinham duas reuniões por dia, uma de manhã e uma à tarde, pra fazer a avaliação e a programação de quais estratégias seriam montadas. E o chefe da segurança, Sr. Lázaro, ficou com a incumbência de articular as pessoas pra fazer espionagem lá fora. $O$ Ivani assumiu o papel de cortar as madeiras, e o Sr. Lázaro assumiu o papel de articular a espionagem. Quando eu saí pra almoçar, eu já tinha aquelas pessoas de alta confiança que estavam na greve. Eu chegava lá e falava: "Fulano," - um deles era o Etevaldo, que não trabalha lá mais, o outro era o Abílio "em tal lugar tem tantos sarrafos. Se nós entrarmos, é pra descer o pau em vocês. Se nós matarmos um de vocês, ou quebrarmos os ossos de um de vocês, a polícia vai assumir. Então a primeira coisa..." Só que aí, Guilherme, você tem que saber com quem você está falando. Não podia falar pra qualquer tranqueira senão você se ferrava todinho. Era meu caso que estava lá dentro. Eu disse: "Vocês já sabem o que fazer. Se vocês entrarem pelo portão tal, os sarrafos estão em tal lugar. Primeiro lugar que vocês têm que dominar é esse, pra não deixar que a gente pegue. Porque eu não vou poder me afastar”. Eram trinta e poucas pessoas de chefia que estavam ali dentro. Eu não podia me recusar sozinho. Pelo menos pegar na madeira eu ia ter que pegar. Muito embora eu já tinha na cabeça em quem eu bateria. Não ia bater em peão. Acidentalmente, eu já sabia em quem eu bateria. [risos] Já que podia matar ou quebrar um, que não teria problema, eu já sabia perfeitamente em quem eu ia bater. E foi muito legal, cara! Porque aconteceu. Aconteceu a invasão. O pessoal quebrou o portão. No que entraram, foram todos em cima daqueles blocos de madeira. [risos] Aqueles sarrafos que seriam pra nós usarmos, serviram de arma pra eles. Aí não deu pra polícia confrontar, não. Recuou todo mundo. Aí foi o dia que apedrejaram, deu um rebuliço mais ou menos. Aí eles ficaram preocupados depois em saber como é que o pessoal sabia que tinha madeira ali. Todo mundo ficou na sua. E a partir desse ponto, já começaram a negociar. Isso aí foi de manhã cedo, que teve a reunião. Eu passei essa informação. Na parte da tarde desse mesmo dia não houve nada. No dia seguinte é que houve a invasão de manhã. Aí a gente não teve nem como fazer essa reunião. O pau comeu. Na parte da tarde a gente já foi fazer a avaliação. E aí que saiu o questionamento: como eles puderam saber dessas madeiras? Ninguém sabia. Lá, quando eu passei as informações, eles também já tinham os contatos deles.

Aí tinha um cara, rapaz, muito amigo meu. Inclusive o irmão dele está aqui em São Paulo, era da oposição, tinha até ganho o Sindicato, que eu falei contigo da outra vez, o Anísio Batista. O Zé Batista, eu chegava nele e falava: "Zé, pelo amor de Deus, Zé! Não 
bebe, caralho. Você fica bebendo na hora do almoço e começa a falar abobrinha, seu nome está lá na lista. Fica tranqüilo que seu nome vai entrar na lista". Ele falou: "Vai tomar no teu cu! Não tenho nada a ver com isso! Você é pelego! Vai lá pra dentro, não vem dar palpite aqui, não". "Zé, há quantos anos a gente está batendo juntos? Você me conhece, porra. Eu assumi uma posição aí dentro, e estou fazendo um papel ridículo, porque eu fui chamado pra ficar do lado de lá e venho aqui dar o suporte. Na minha cabeça, eu nunca deixei de ser peão. Sou peão. Não é porque estou exercendo um cargo de supervisor que sou o dono da empresa. Pô, eu tenho um cargo de confiança”. Lógico que eu não fiz essa discussão toda com ele, porque ele estava bêbado. Como é que eu vou discutir com um cara desses? O meu objetivo era orientá-lo pra não beber, porque ele inflamava bastante a coisa, e mais os outros lá. Enquanto a empresa punha amigo lá fora pra tacar bebida. Pra pagar bebida e jogar panfleto pra colher informação. E aí, quando aconteceu essa invasão, como eu disse, nessa avaliação toda, já saiu uma proposta de negociação. Nessa reunião da manhã. Falei: "Bom, vamos fazer o seguinte. Vamos pedir pra que eles façam assembléia e tirem uns quatro ou cinco pra negociar. Nós vamos ceder em alguma coisa”. Já passei a informação rapidamente. Quando eles já chamaram uma assembléia, dei uma escorregada aqui e ali. Também a gente se comunicava por sinal. Como eu não podia ir lá no meio deles, um sinal que eu fazia, uma pessoa dessas que a gente se entendia bem se deslocava pra algum banheiro ou coisa parecida, e eu ia "pá, pá pá" no ouvido, em voz baixa, e de olho pra ver se não tinha ninguém ouvindo. Tinha que fazer todas essas jogadas. Então se formou a comissão, conseguiram negociar. Só que nessas alturas já tinham rolado muitas cabeças. Em torno de trezentas pessoas já tinham sido mandadas embora. Também já começou o fracasso de produção. Com esse tempo todo parado, já foram perdendo alguns contratos. Mandou uma infinidade de gente embora. Mas a gente conseguiu, através desse confronto, fazer a negociação. Na assembléia tiraram os nomes. Esses nomes vieram pra fazer as reuniões. A firma ia conceder algumas coisas, outras não. Eu até listei pra pessoa: "Já avalia que a firma está concedendo isso, isso e isso. Agora vê como vai ser conduzida a assembléia pra vocês fazerem a votação. É hora de parar e pensar. Trezentas cabeças já rolaram. O clima está meio complicado. Ou a gente decreta guerra pra valer, ou vamos parar de brincar de bobo, porque eles estão vencendo a gente pelo cansaço. Vamos tomar cuidado com isso aí”. E acabaram negociando mesmo. Na assembléia, não daquele dia, mas do dia seguinte, acabaram negociando o fim da greve. Conseguimos bastante resultado. A questão do restaurante... foram tantas coisas que não me lembro de cor, agora. Foi até um erro. Eu deveria ter escrito isso. Mas eu não sou muito de pegar papel e ficar lendo coisa que acontece. Eu vou buscar naquilo que está gravado na memória, que são fatos que me marcaram.

Só que aí, Guilherme, nessa greve ainda, comentei isso contigo em outros momentos, foi nessa greve aí que nasceu meu filho mais novo. Não, essa foi de 82. Essa foi em outro momento. Nessa nasceu minha filha que hoje é professora. Foi na greve de 85. A partir de 82 as greves foram fracassando, fracassando, fracassando. A última greve mais forte que a gente fez lá foi em 85. Foi no ano que nasceu meu filho mais novo, que está fazendo engenharia agora. Essa greve também foi pesada. Muitas cabeças rolaram. Foi mais ou menos nessa base de ir vencendo pelo cansaço, conflito com a polícia. Lá na unidade que eu trabalho a gente conseguiu um esquema de não deixar ninguém ir preso. A gente se 
organizou de um jeito que ninguém fosse preso. Nessa greve de 85, como eu estava inteirado nos assuntos, já de experiência das greves anteriores, falei: "Não posso arredar o pé de forma nenhuma. Porque é muito importante eu saber o que está acontecendo aqui. Meus companheiros lá fora vão pagar o pato por isso. Se não tiver alguém aqui pra informar, muitas cabeças inocentes vão rolar, muitas pessoas que não têm nada a ver como peixe vão rolar. Então eu vou ter que estar passando informação. Pego aqui na reunião, na medida do possível já jogo isso aqui lá pra fora”. Só que nessa de 85, já não era só eu de supervisor, que já tinha essa visão. Tinha um outro líder, inclusive eu trabalhei muito bem durante o processo, que já passou a ter essa concepção, essa visão. Não é porque você pega um cargozinho em firma que você muda sua visão. De forma nenhuma. Ficou mais fácil pra gente estar costurando, pra poder estar passando essas informações. Mas aí rolaram um monte de cabeças, também. Foi aonde pintou essa história do meu filho. Fui conhecê-lo ele tinha três dias de idade, cara. Nesse movimento de greve, eu sabendo de tudo que poderia acontecer, eu fiz a seguinte avaliação: "Lá no hospital, eu tenho a certeza que minha esposa vai ter a assistência necessária. Ela está internada, tem toda a assistência técnica que for preciso. Então, pra mim, nesse momento, eu vou ser muito mais útil aqui do que lá”. Optei por isso aí, uma questão de opinião da gente. É uma coisa que muitos até questionam. Mas uma opção minha, fiz essa opção. Não existe ninguém que gosta tanto da família como eu. Mas consigo ver a coisa mais ampla, um pouco. Nessa aí fui conhecê-lo com três dias de idade, por motivo dessa greve, que foi uma greve longa, que a gente conseguiu quebrar um monte de tabus que havia lá dentro, um monte de pendências. Nessa greve aí foi onde a gente conseguiu o restaurante. Conseguimos vale transporte, conseguimos um aumento, um aumento real além da inflação. Mais o quê além disso aí? A questão das companheiras que ganhavam neném e eram mandadas embora, ao ficarem grávidas eram mandadas embora. Isso aí está na Constituição, mas não estavam obedecendo. A gente conseguiu fazer valer isso aí. Criamos comissão de fábrica a partir daí. E assim foi avançando.

Só que nessa greve de 85, depois que fecharam os acordos das reivindicações que a gente tinha... já tínhamos fechado durante a greve, primeiro que a firma ia dispensar bastante gente. Eles falaram: "Vamos ter que enxugar isso aqui, vamos ter que tirar bastante gente". Aí eles diziam assim: "Não existe um momento melhor do que esse. Todo suspeito vai ser demitido. Todos, todos. Sem exceção de nenhum”. Terminou a greve, começou a caça às bruxas. Já foi convidado um supervisor, o filha da puta já foi logo com uma lista de quinze nomes. Foram todos. Outro, acho que vinte nomes. Não me lembro o número exato. Foram todos. Aí, Guilherme, que eu fiquei bastante marcado nessa empresa. Me convocaram: “Adão, quantos vão lá do seu setor?" "Nenhum." "Como? Fulano é agitador, Sicrano também”. Eles apontaram cinco como agitadores do meu setor. Eu falei: "Engano seu. Vocês não viram eles participando de nada aqui. Desafio vocês: quem daqui viu?". Nessas alturas do campeonato, nessa sala, tinha o Santino Carlos, que era o chefão lá dentro, tinha um japonês de nome Makoto, e o Sr. Moisés, que era o chefe de recursos humanos, já pra deixar tudo pronto. Quando eu fui com essa postura, que ninguém do meu setor iria: "Mas por quê? Se todos os outros setores têm, o seu tem. E nós vamos levantar nomes”. Aí levantaram nomes, citou o Etevaldo, o Zé Bonfim, que está lá até hoje, o Abílio, a Maria Zilda e a Dona Lídia, como os cabeças. Falei: "Não, engano seu, nenhum desses participou. Eles ficaram na greve porque não dava pra ninguém furar a greve. Vocês sabem que quem tentasse passar 
entrava no porrete." "Não, mas tem gente que entrou, porque eles não entraram?" "Bom, essa pergunta não sei responder. Mas eles não são grevistas, não são agitadores, são pessoas excelentes. E no setor, como vocês têm aí no arquivo de vocês, eles estão requisitando mais cinco funcionários. Porque vocês vão mandar mais cinco? Aí eu vou ficar com uma defasagem de dez. Como eu vou atender a produção que vocês querem?”. Aí o filha da puta do japonês, radical pra caramba... inclusive, Guilherme, parece mentira, cara. Acredite se você quiser. Os caras tinham cacetetes em cima da mesa pra conversar com a gente. Parece que os caras eram da polícia e você era bandido. Não os três, dois deles tinham. Os dois que controlavam esse negócio do pessoal, os recursos humanos. Esse do recursos humanos estava com seus livros, suas folhas, mas é um grande filha da puta também, esse cara. Tanto que foi mandado embora antes de aposentar. Se ferrou. A gente lamenta, que apesar de ter cabeça de patrão, é peão também. Tanto que está pagando caro por essa besteira dele. O japonês bateu o cacetete debaixo da mesa: "Você não vai mandar?" "Não." "Então eu escolho!" "Makoto, você fica à vontade. Só que na medida que você está me tirando a autoridade do meu setor, você põe o meu nome em primeiro na lista. Você só vai fazer o que você quer no meu setor depois que você me tirar de lá, porque lá eu sou supervisor. Você é o meu superior, mas supervisor daquela área, quem responde por esse pessoal, sou eu. Pra tirar uma pessoa de lá, você põe o meu nome primeiro. Eu só pediria a vocês que respeitassem uma pessoa, que é um deficiente de audição, e é mudo." "Mediante essa sua postura aí, Adão, não sei." "Já falei, façam o que quiserem, com essa condição: põe meu nome aí.”. Aí conversaram entre os três lá: "Faz o seguinte: nós vamos estudar esse caso" e já ligaram pra vir outro supervisor. Quando outro supervisor foi entrando e eu saindo, perguntou: "E aí? Menos dez lá?" "Depois te falo o número". Ele estava trazendo uma lista de doze. Não é falar que eu sou bonzinho. Mas fui o único supervisor nessa greve de 85 que não deixou sair um dos subordinados. Não saíram. E ficaram lá. Por sinal, a Maria Zilda ainda trabalha lá. O Zé Bonfim ainda trabalha lá, até hoje. A Dona Lígia se aposentou, o Etevaldo teve que sair. $O$ Abílio teve que sair, por algum motivo ele ia embora. Mas saíram assim, de boa. Não foi por perseguição de greve. Foi questão que eles até pediram pra serem mandados embora, que eles tinham que ir embora mesmo. Com a exceção da outra que aposentou, deu o tempo dela e aposentou. Mas hoje estão lá. Dona Maria Zilda que está lá, ela não é bem vista, porque ela adquiriu doença no decorrer da profissão dela lá, esse negócio de problema na junta, deu um monte de problemas. Ela está estabilizada por doença. Mas naquele momento eu a segurei, e depois ela se estabilizou por doença, e vai ficar lá até aposentar. E o Zé Bonfim é uma excelente pessoa, que eu consegui segurá-lo. Eu saí e ele ficou. Está lá até hoje. Olha, todo lugar que ele vai trabalhar, o pessoal o adora. Até que chegou mais pro final dos tempos, que nos setores até o supervisor foi terceirizado. Foi vendido na hora que trocou de dono. Mesmo assim não foi dispensado nenhum dos profissionais do setor. Foram todos transferidos. E a maioria está lá hoje. Aqueles que não aposentaram estão lá, e a cotação é a seguinte: nos setores onde estão trabalhando são os de melhor desempenho. Eles passaram por um puta de um treinamento, eu fiz um puta de um treinamento com eles. Não de produzir, mas de conhecer seus direitos e deveres. Quando eu indico os direitos da pessoa, faço questão de frisar os deveres. Uma coisa não pode ser desligada da outra. Não existem direitos sem deveres, e vice-versa. 
Depois houve outras coisas mais localizadas no decorrer. Aí não sei te citar a data certa, mas foi ainda nos anos 80, 90. Já estava muito fraco o movimento. Alguma coisa que eu tive que peitar lá dentro como presidente eleito pela CIPA. São vários fatos, mas eu vou citar pelo menos dois, ou melhor, vou te contar três, dos que me marcaram mais.

Um foi em relação à água. Com esses problemas que começaram, que, diziam eles, estar em decadência, os filtros - nessa época já havia sido colocada a água, que foi uma conquista lá atrás que a gente teve. Tinha os bebedouros. Não tinha água gelada, mas era água filtrada. Vinha da caixa, mas era água filtrada. Só que a água vinha com muita sujeira, e os filtros ficavam todos impregnados. Como a firma alegava situação financeira difícil, esse mesmo Ivani que cortou a madeira, tomou a liberdade de aumentar a vazão dos filtros. $O$ cara ia beber água e não saía, porque o filtro estava impregnado de sujeira. Então ele foi lá e sacou, jogou os filtros fora, e o pessoal usava a água pensando que estava filtrada, e não estava. Só que aí o que aconteceu? A caixa também não era cuidada. Vinham larvas no meio da água. O pessoal pegou aquilo e percebeu. Exceto aqueles que pegavam água direto do bebedor. Quem pegou no copo teve oportunidade de ver a larva. Já trouxeram pra me mostrar. Aquilo gerou um rebuliço que o pessoal já queria parar. Eu falei: "Calma, vamos acertar isso aí. Eu sei que é uma sacanagem muito grande, mas vou tomar providências de imediato. Se até amanhã isso não for resolvido, aí nós paramos". Fui até o segurança, falei com ele. Fez um sinal que não estava nem aí, o Sr. Lázaro. Falei: "Não posso deixar isso continuar". Fui nos recursos humanos e falei com esse Moisés. Ele falou: "Olha, eu cuido aqui de papelada. Como é que eu vou me envolver com isso aí?". Falei: "Porra, mas tá danado. $O$ chefe de segurança não diz nada. $O$ chefe de recursos humanos não diz nada. A peãozada já quer resolver". Aí pulei todas as instâncias. Fui direto pro presidente da empresa. O falecido Leonel, que na época era um nó cego do caramba. Autoritário que era o diabo. "Sr. Leonel, dá licença". Ele abaixou os óculos assim: "O que você quer?" "Vim mostrar pro senhor a água que o pessoal está bebendo na fábrica”. Ele olhou assim: "Não, isso foi você que pôs". "Sr, Leonel, pelo amor de Deus, não faça uma acusação dessas, que o Sr. está me enquadrando como bandido. Eu não posso fazer uma coisa dessas. O Sr. é louco?" "Olha, vê como você fala comigo!" "Eu vim trazer uma reclamação pro Sr. Eu já falei com o chefe da segurança e ele não está nem aí, o chefe de recursos humanos não está nem aí, e o pessoal vai parar se o Sr. não tomas providências". Ele falou: "Está bom". Chamou a secretária dele que estava na sub-sala. O nome dela era Maria José, a gente a chamava de Zezé. "Zezé, pega o meu copo", um copo de vidro, "e vai com o Adão ao bebedouro coletar amostra de água. Ele me trouxe uma água aqui cheia de bichinhos, que ele deve ter colocado pra incentivar o pessoal a fazer greve”. Deu vontade de dar um murro no cara. Lá fui eu. Essa Zezé trabalhava com serviço social, mas ela estava como secretária lá. Mas era formada em serviço social. Ela falou: "Olha, Adão, isso é uma coisa muito séria. Se você tiver sacaneado, vai sobrar pra sua cabeça". Falei: "Escuta, faz o que seu chefe mandou que já está de bom tamanho. Eu respondo pelos meus atos”. Já estava p. da vida por ser agredido por um e por outro, e ela vai me falar besteira ainda! Falei: "Faz o que seu chefe mandou. Eu respondo pelos meus atos”. E fomos. Chegou lá, ela apertou o dedão no bebedouro pra entronar a água. Seis bichinhos. Ela levou pra ele. "Você é uma tonta. Ele pôs isso no caminho e você não viu”. Você tem que ter paciência, rapaz. Não dá vontade de dar um tapão na orelha do cara? [risos] "Faz o seguinte. Joga essa coisa fora, lava bem esse 
copo, seca e me traz que eu quero olhar". Ela fez. "Pega aquele rolo de guardanapo". Ela pegou. Ele pegou uns três. "Vai com isso aqui tampado. Chega lá, você enche e tampa novamente. E o Adão vai ficar aqui comigo, que eu quero ver se você vai colocar bicho no meio do caminho. Você parece que está dormindo que não vê as coisas". Pensei: "Caramba! Agora que ferrou! Será que essa mulher vai filtrar esse raio dessa água?”. Eu não tive tempo pra botar alguém pra ficar de olho, pra ver o que acontecia. Poderia ter montado esse esquema. Como fui pra tomar uma providência, não deixei o esquema montado. Mas nessa parte ela foi coerente. Ela foi lá, coletou a amostra direitinho e trouxe. Quatro bichinhos dentro do copo. "E agora, Sr. Leonel? Como é que fica essa situação? Eu que sou infrator? Ou a empresa que é incompetente?". Aí já comecei a ficar arrogante com o cara. "Qual prazo que o Sr. quer pra resolver isso aí? O mínimo possível, senão eu volto lá pra fábrica e nós vamos parar agora! Vou denunciar isso na imprensa, vou denunciar no sindicato. Vou fazer um rebosteio danado com isso aí". Já usei palavrão com o cara. Ele arregalou o olho pra cima de mim: "Posso te mandar embora!" "Eu sei, o Sr. é dono da firma. Pode mandar a hora que o Sr. quiser. Menos fazer as acusações levianas que me fez. Mandar embora o Sr. pode mandar, agora fazer essas acusações, o Sr. nunca mais vai fazer isso comigo. Porque hoje demonstrei pro Sr. que sou um homem, não moleque”. Bem na sala dele! Ele falou: "Chega de prosa. Vamos tomar uma ação". Falei: "Isso é o que eu quero". Pegou o telefone, rapaz, ligou pro engenheiro de manutenção chamado Sr. Luís Martinez. "Luís, você tem até à tarde pra colocar filtro em todos os bebedouros e lavar a caixa d'água, senão eu mando você e o chefe da manutenção embora". [risos] "Ah, mas como é que eu vou comprar?" "Problema seu. Você tem até amanhã pra instalar isso". Falei: "Está bom, Sr. Leonel. Vou pedir pro pessoal curtir a sede até amanhã. Eu vou checar bebedouro por bebedouro, que não são muitos. São oito. O que estiver sem filtro já vou colocar uma fita isolando, interditado, com a sigla da CIPA". Ele falou: "Pode fazer". Só sei que no outro dia cheguei a interditar três, que não deu tempo de eles colocarem tudo. O processo de compra, essa coisa toda, um corre-corre danado. Interditei três. Na parte da tarde o chefe da manutenção queria me descer a marreta na cabeça quando eu interditei. "Você quer aparecer? Pendura uma melancia no pescoço, ou pinta a unha de vermelho". Falei: "Meu, dispenso comentários com você. Faz o que teu chefe mandou que já está de bom tamanho. Você acha que eu estou de sacanagem com os colegas de trabalho? Você é doido?”. Ele: "Sai daí senão te pico essa marreta na cabeça". "Eu não duvido nada de você fazer isso. Só que não vou te dar chance de fazer isso, não. Você vai bater em outro, em mim, não”. À tarde ele terminou tudo. Fui lá, coletei as amostras de água. Aí já exigi mais. Peguei a água, fui lá à tarde: "Sr. Leonel. Obrigado pela ação. Só que agora vou pedir pro Sr. fazer mais uma coisa. Vou pedir pra fazer uma análise dessa água e colocar o resultado no quadro. Foi o que eu acertei com o pessoal lá. Que além da troca dos filtros, iria pedir uma análise da água. Já estava gerando bicho, vai saber o que tem nessa água?” Aí ele não quis alterar comigo mais, não. Já chamou o chefe de segurança na hora, o Sr. Lázaro: "Lázaro, coleta a água, manda pro Adolfo Lux, e pede urgência nesse laudo". Trouxe, colocou o laudo lá na mural.

Então esse foi um ponto que me marcou muito durante a minha gestão de CIPA. Porque aí as greves foram reduzidas. Estou falando mais do local onde trabalhei. O outro foi a questão do restaurante. Nas greves anteriores a gente havia conseguido o restaurante. Só que aí tinha três padrões de comida nesse restaurante. Tinha a lavajona pra ralé, tinha um 
intermediário no qual eu me encaixava pra comer. Quase não tinha diferença, a comida era a mesma, só que já não era o bandejão. Tinha mesinha, você se servia do seu jeito, e às vezes mudava a mistura. Só que eu não aceitei almoçar nesse departamento, eu preferia continuar na fila do bandejão com o pessoal. Eu precisava saber o que estava acontecendo. Além desses dois modelos, tinha a comida da autarquia da empresa, os diretores, que já tinha uma cozinheira contratada que fazia comida lá de acordo com o cardápio que eles determinavam no dia. Eram três padrões de comida. E na comida da ralezona, com quem eu comia junto, por opção, eu poderia muito bem estar em uma sala do outro lado - até os colegas meus falavam: "Pô, mas você é dose. Os caras tentam arrumar uma coisinha pra gente, você mija pra trás, e vai lá pro outro lado. Você queima nossa imagem, nosso lugar é pra cá. Você não tem o que se misturar com esse pessoal”. Eu não respondia nada, senão eles me dedavam. Complicada essa situação. O pior de tudo, Guilherme, os peões que almoçavam junto, parte deles achavam que eu estava fazendo espionagem no meio deles. Mas eu tinha uma grande parcela de pessoas que, pelo bom relacionamento, já sabiam qual era meu objetivo ali. A gente sentava junto, fazia brincadeira na hora da comida. Apesar que, com todo respeito à alimentação, era uma bela de uma porcaria. Meu, a mistura vinha uma tranqueira! E a gente não se servia, não. Quem servia a gente era o pessoal do restaurante contratado. Era o tanto que eles queriam pôr, e isso não se discute. Única coisa que podia se servir era o arroz e o feijão. $O$ resto eram eles que colocavam. Era aquilo e não tinha discussão. Pra começar, já ficava o banho-maria e a parte que cobria o resto, e você não via nem quem estava te servindo. Não podia nem fazer assim pra ficar olhando que você tinha chamada a atenção, por estar contaminando a comida. Caía cabelo, saliva, ou coisa parecida. Num determinado dia, meu horário de almoço era meio-dia. O pessoal que saiu às onze pra almoçar, o segundo que pegou a bandeja já veio aquele cheiro. Aquela asa de frango podre. Aí já deu um jeito de sair ali, não podia entrar dentro da fábrica no horário de almoço. Os guardas ficavam olhando. Mas ele deu um jeito que chegou na porta de uma sessão e pediu pra alguém falar pra eu ir ao restaurante. Eu podia ir e voltar, pelo fato de eu estar na CIPA, eu tinha livre acesso. Quando eu cheguei na porta, ele falou: "Adão, mandaram asa de frango estragada. Tá um fedô que ninguém agüenta!", [risos] usou um vocabulário bem popular, mesmo. "Tá um fedô que ninguém agüenta. Tá uma carniça aquilo lá”. Falei: "Sério, cara?" "É”. Cheguei lá, deu uma misturada, subiu aquele mau cheiro, meu estômago fez assim. Falei pro pessoal: "Pára! Ninguém vai mais comer!". Aí veio o chefe da cozinha, começou a me xingar, falei: "Não tenho nada com você. Vai falar com quem te contratou". Falei: "Pessoal, quem estiver com muita fome, pega as outras comidas, não dá o vale pra eles," que não passava o crachá, você dava um contra-cheque, um valezinho, "não dá o vale, e não pega a carne que ela está estragada". Aí veio o segurança, já com dois guardas da firma mesmo. Daí a pouco veio o chefe de recursos humanos: "Mas Adão, porque você sai lá do serviço e vem agitar aqui?" "Não é agitação, não. Essa carne está estragada. Dá uma olhada”. Ele pegou, olhou: "Está estragada coisa nenhuma!". Falei: "Então come”. Aí não conseguiu comer, não. "Então faz o seguinte: vou trocar essa carne”. Falei: "Espera, mas já tem outra pronta? Se não tiver, como é que vai fazer? O pessoal vai ficar esperando aí, tem que bater cartão de volta pra trabalhar". "Não, o pessoal pode ficar, se atrasar, eu abono as horas". "Mas está saindo a outra turma, já. Olha a fila se formando". Ficou uma situação insustentável. Botaram um monte de ovo pra cozinhar, deram ovo cozido pro pessoal. Só que 
aí virou um conflito danado. Porque eles começaram a me agredir, ameaçando de dar justa causa, essa coisa toda. Eu mais que depressa fui até a portaria, catei o telefone, liguei pro Sindicato. O guarda de olha em mim, ouvindo tudo. Já pedi pro Sindicato ligar pra polícia vir imediatamente, pois estava acontecendo um crime grave. Daí a pouco chegou a viatura da polícia. O cara do Sindicato não deixaram entrar. Aí quem foi fazer a recepção aos policiais foi o chefe de recursos humanos, esse tal de Moisés. O policial: "O que está acontecendo?" "Esse cara aí está agitando. Olha lá como está aquele tumulto de gente. Está agitando, ele alega que a carne está estragada". A polícia veio pra cima do meu lado: "O que está acontecendo?". Falei: "Boa tarde. Acontece o seguinte: o restaurante contratado pela empresa está servindo carne estragada pro nosso pessoal. E eu tomei a iniciativa de impedir que essas pessoas se intoxiquem com essa comida. Carne estragada, não sei se vocês conhecem isso, mas é um agente tóxico. Vai dar muito problema isso aî”. Aí o chefe de recursos humanos: "É mentira, rapaz, isso aí não aconteceu. Você pode ver que nem carne tem, estão servindo ovo”. Eu falei: "Não, ele tem razão, estão servindo ovo. Mas foi como opção, porque não tinha outra coisa". Aí o policial: "Eu vou lá. E se não achar carne estragada, você vai preso”. Falei: “Perfeitamente”. Só que aí, valeu toda a organização que a gente tinha. Enquanto eu estava fazendo essa conversa e essa recepção, o restaurante recolheu toda a mistura que estava estragada, jogou dentro de um tambor de 200 litros, o cara meteu num carrinho, e levou lá pro fundão da fábrica. Só que já tinha uns quatro carinhas meus de olho nisso. Na hora que eles viram que eu vinha junto com a polícia e com o cara do recursos humanos, fez um sinal pra mim. Falei: "Dá licença que eu vou no banheiro". Cheguei e ele falou [voz de sussurro]: "O tambor está lá nos fundos". A polícia chegou lá e falou: "Uai! Nem carne tem aqui. Que conversa torta é essa sua? Você vai ter que explicar isso na delegacia". Falei: "Mas primeiro vocês olhem aquele tambor que a carne está lá, a carne estragada." "E se não estiver lá?" "Eu vou preso”. Aí perguntei: "E se estiver?" "Aí é problema nosso". "Tá legal”, ainda na ditadura, meu, não podia fazer muita coisa. Chegamos lá, quando destampou o tambor, tirou o narizfora que não agüentou o cheiro. Estava fedido mesmo. Aí ele pediu pro chefe de recursos humanos voltar e mandar alguém levar sacos plásticos para ele coletar a amostra. Pensei: "Seria bom ter chamado a imprensa. Pena que não deu”. Vestiu um saco plástico na mão, enfiou a mão lá e tirou mais ou menos um quilo e meio naquele saquinho. Isolou e falou: "Vou levar pra análise pra depois a gente ver quais são as medidas que a gente vai tomar. E quando acontecer isso, é melhor que você tome outros caminhos que não ficar agitando". Falei: "O que eu iria fazer? Vou deixar o pessoal se intoxicar? Não seria muito pior ficar empesteando os hospitais de doentes? Podia até morrer gente com isso aí. Eu, na minha concepção, tomei a medida certa. Vamos aguardar o resultado da análise”. Também não quis ficar espichando muito a conversa com os caras. "Vamos aguardar o resultado da análise que vão fazer nessa carne, aí depois a gente discute as medidas que vocês vão tomar a partir daî”. Só que até hoje eu não sei resultado disso, bulhufas nenhuma.

O outro caso foi uma paralisação que a gente teve lá, por conta de duas mortes. Tinha a Dona Maria, que trabalhava no meu departamento mesmo, no período da tarde. Ela arrumou um romance com um guarda, e não sei o que aconteceu que ela saiu pra janta, e quando ela voltou pra trabalhar - naquela época não era cartão eletrônico, era aquele relógio de alavanca - ela bateu o cartão, e esse guarda, que era o amante dela, chamou-a. 
Ela não ouviu, o colega dela tocou nela: "Ô, Maria", não me lembro agora o nome do guardinha, "ele está te chamando lá”. Mas que merda! Voltou: "O que você quer?”. Quando ela chegou na cara dele pra ele falar o que ele queria, sacou um 38 e deu um tiro nela, que os miolos saíram junto com a bala. Aí ela caiu morta. Acho que ele se viu tão apurado que ele meteu o revólver aqui em baixo e deu um tiro nele também. Os miolos dele também saíram. Aí juntaram os outros guardas lá, botaram dentro do carro, levaram pro hospital. Nem a polícia veio fazer perícia nem porra nenhuma. Chegaram lá no hospital, fizeram um arranjo que os caras morreram, essa coisa toda, então não houve interdição, não houve nada. Aí nós, no dia seguinte, resolvemos fazer uma parada em protesto. As pessoas desqualificadas com arma na mão, aconteceu um episódio desses aí. Fizemos a parada, fizemos um ato na parte externa da fábrica. Depois desse ato foi colocada uma proposta pra empresa, pra ela desarmar os guardas. Enquanto ela não oficializasse essa proposta, a gente não voltaria trabalhar. No primeiro dia ela não cedeu. No segundo dia, a gente chegou. Estamos lá. Aí acho que três pessoas em um setor furaram a greve. Já naquela época a coisa estava ficando muito difícil, qualquer coisa mandavam embora, o pessoal se viu no desespero e furou greve, entrou pra trabalhar. O pessoal ficou muito revoltado, queria invadira a fábrica. E esse rapaz com nome de José Bonfim, ele havia concorrido à CIPA, tinha ganhado, e ele conversou com o pessoal pra não fazer aquilo. E nesse meio tempo que ele estava conversando, chegou o pessoal da direção da empresa, pra sentar e fazer a negociação, se eles iriam ceder ou não à nossa proposta. As coisas foram acontecendo rapidamente. O pessoal queria invadir, e o Zé Bonfim os acalmando. Não tinha ninguém do Sindicato pra dizer pra não fazer isso, que era uma coisa errada. Ele reconheceu que o pessoal estava errado em furar a greve, mas é um direito individual. Ninguém pode forçar ninguém a ir. Ele é um cara bem informado. Ele falou: "Olha, nós estamos ferindo a Constituição ao fazer isso. Estamos impedindo o direito do cidadão de ir e vir. Muito embora a vontade da maioria é o que estamos fazendo aqui. Mas esses três que foram pra lá, inclusive um homem e duas mulheres, uma delas da CIPA, nós não podemos impedir o direito deles de ir e vir". Aí o pessoal não se conformava. Ele fez uma proposta: "Pode deixar que eu vou pessoalmente convencer essas pessoas a virem para o meio da gente. Com uma proposta: ninguém vai vaiar ninguém”. Aí foi acatada a proposta deles. Ele entrou. Quando ele entrou pra ir lá conversar com as pessoas, o chefe de segurança foi atrás dele com dois guardas, disse que ia prendê-lo, porque ele tinha ido lá dentro pra agredir as pessoas. Rapaz! Foi um rebuliço danado, aí tive que intervir: "Não, de forma nenhuma. Eu ouvi todo o encaminhamento do pessoal que estava aqui fora, o conheço muito bem. Ele é incapaz de fazer isso. Ele não faria isso de forma nenhuma. Ele foi conversar com essas pessoas pra evitar um acidente maior, porque o pessoal está revoltado. São muitos, mais ou menos umas quinhentas pessoas contra três. Se esse pessoal entra aqui haverá um vandalismo danado, além das vidas dessas pessoas". Era a merda que poderia acontecer, que era o que a empresa queria. Tudo que ela queria era isso, que o pessoal entrasse, quebrasse tudo. Iriam mandar um monte de gente embora, enquadrar, essa coisa toda. Aí foi um Deus nos acuda, porque quando eu vi que o chefe de segurança, que era o Sr. Lázaro, entrou com os dois guardas, fui atrás e falei: "Vocês vão fazer o quê??" "Nós vamos prendê-lo. Ele não pode fazer isso. Se a menina entrou pra trabalhar, ela tem suas razões". "Ele não vai agredir ninguém. Ele veio conversar." "Mas não vai conversar." "Você não pode impedir isso". E acabou que ele não conversou com ela, porque de longe ela já o 
agrediu também. Ele não esperava essa reação. Ele foi tão maduro, que de longe ela o agrediu, e ele abaixou a cabeça. Voltou, e veio negociar com o pessoal. Falou: "Olha, o chefe de segurança já entrou com dois guardas, foi convencê-los a sair”. Olha só a cabeça do cara, ele não chegou inflamando a assembléia. Nesse meio tempo eu já intervim no assunto. Falei: "Sr. Lázaro, por favor, tira essas três pessoas daqui de dentro. Caso contrario, nós dois vamos sentar juntos agora e fazer um relatório, e eu assino e o Sr. assina. O Sr. vai se responsabilizar pela vida dessas pessoas e pelo patrimônio. Porque se o Sr. não fizer isso, eu não me responsabilizo pelo que pode acontecer. Nós vamos colocar isso em papel. O Sr. estava fazendo um ato de covardia com o Zé Bonfim, ele foi impedido de fazer isso, a menina se sentiu fortalecida com sua presença mais os dois guardas, e o agrediu. Nós vamos relatar. Nós vamos anotar que ele entrou por motivo $A, B, C$ e $D$, que a reação dela foi essa, assim, assim e assim, que o Sr. veio com as duas pessoas para capturá-lo e eu vim impedir. E eu vou assinar em baixo. Caso contrário, o Sr. se responsabiliza pelo que pode acontecer”. Ele falou: "Não, não, ele também era um bocudo. E você não vai fazer bosta nenhuma, rapaz, que merda de relatório nenhum. Pode deixar. Uma das coisas que você falou eu vou fazer. Vou chegar lá e pedir pra ela sair pra fora da fábrica, que eu não quero confusão". Falei: "Então você espera um pouquinho, que eu vou lá fora conversar com a assembléia. Agora, nesse momento, a coisa está inflamada”. Cheguei lá, chamei o Zé Bonfim e falei: "Olha, propõe ao pessoal pra deixar um beco aberto aqui, e as pessoas vão sair. Mas eu não quero que ninguém agrida as pessoas, você pede pra ninguém agredir ninguém, que está todo mundo de olho. Pode dar confusão”. Aí saíram. Saíram as duas mulheres e o rapaz. Não levaram pancada não, mas o pessoal: "Filha da puta! Viado!" E os caras metiam a mão na bunda das mulheres, metiam a mão na bunda do cara. Pô, mais do que merecido, uma puta de uma sacanagem. E a partir daí, criou-se um isolamento que nem os funcionários falavam mais com esse pessoal. No fim eles acabaram perdendo o emprego. Foi só a estabilidade deles.

Então, mais no local que eu trabalhei, Guilherme, foram esses fatos assim que marcaram muito. Mas além disso, a infinidade de coisas de greve, fica até difícil, dentro de uma firma, é meio complicado pra você acompanhar tudo. Mas como cipeiro, utilizando desse suporte previsto em lei, que é a portaria 3214, a gente se enquadrava mais na NR5, mais especificamente essas questões de acidente de trabalho, e direitos e deveres da gente. Eu consegui, junto com outros colegas de serviço, fazer muitas coisas. A gente se envolveu nas questões. A gente sai um pouco das greves, mas é conseqüência uma coisa da outra. Foi um processo de a gente participar da derrubada dos militares, Diretas Já, a defesa de indústria nacional, o "impeachment" do Collor. Trabalhei tudo isso. Quando teve a virada do ano de 2002, nas retrospectivas dos movimentos, eu sentado na sala com meus filhos, eu falei: "Olha, naquele movimento eu estava, naquele eu estava, naquele eu estava”. Foi muito legal isso aí, de falar que eu estava, eu estava nesse lugar naquele momento. Foi tudo negociado assim. Foi super legal.

Nas greves gerais, a coisa foi um pouco mais complicada, já não tinha muita ação da gente, porque isso já era uma coisa mais organizada com as instâncias superiores. A primeira greve geral foi um sucesso, muito bom. A última greve geral chamada pela categoria, não sei se foi bem a categoria. Aqui em são Bernardo, no ABC, a categoria sumiu. Não sei te dizer exatamente. Foi nos anos 90, já. Não sei te dizer exatamente o ano. É tanta 
coisa que a gente acaba esquecendo. Pra mim foi uma decepção muito grande essa greve. Eu morava aqui, aliás sempre morei aqui. Saí daqui às quatro horas da manhã, peguei, inclusive eu até pedi a uma pessoa, que eu não tinha carro na época, pedi a um colega meu, paguei a gasolina pra ele, porque nesse horário é complicado. Pra chegar no horário que a gente tinha que chegar lá. Conversei com um amigo, a gente pagou a gasolina pra ele. Fomos eu e um vizinho meu. Nós fomos participar da greve geral. Nós havíamos marcado nosso ponto de partida ali no terminal de Diadema. Quando foi quatro e quinze da manhã, eu e esse colega meus já estávamos lá, e lá já encontramos muitas pessoas. E nós nos reunimos dentro do Sindicato dos Químicos, que era lá, pra traçar algumas ações, algumas estratégias do dia, que não pôde soltar isso na Tribuna porque se você falar todo que você vai fazer, você é impedido. Na hora que eu cheguei lá já tinha viatura da polícia pra todo lado, cavalo, cachorro, helicóptero por cima jogando o farolete por cima da gente. Nos reunimos na sede do sindicato, só que aqueles mesmos esquemas de organização. Alguém percebeu que a polícia ia invadir a sede e prender todos nós. Antes da polícia chegar, nós saímos. Deixamos as portas todas abertas, as luzes todas acesas. Quando a polícia invadiu, só encontrou as mesas. Enquanto eles estavam invadindo o prédio, nesse dia cometi um ato de vandalismo. Quebrei dois trolebus pra impedir a circulação deles. A greve não era só da categoria, era greve geral. E os motoristas dos trolebus são na sua maioria gente que trabalha na corporação da polícia, ou aposentados, ou gente muito próxima da polícia. É coisa de confiança do governo do Estado. Nós chegamos e quebramos logo dois. Impedimos a circulação. Com aqueles dois trolebus quebrados, nos dois sentidos, nós impediríamos a circulação. Só que a gente agiu rápido, porque percebemos que a polícia ia agir rápido também. Ao sair dali, já encontramos uma colega. Ela já tinha levado uns tabefes da polícia. Já estava com o nariz sangrando. Ela conseguiu escapar pulando o muro. Aí tirei minha blusa e dei pra ela vestir a blusa. Meu colega passou o boné pra ela ficar irreconhecível, porque já a tinham marcado. Pedi pra ela: "Dá o fora, porque se eles te pegam, eles te matam”. Só que aí nós fomos conversando, negociando. A polícia dispersou aqui e ali. Deu seis horas da manhã. $O$ número de gente era pequeno. $O$ vice-prefeito de Diadema, Joel Fonseca, era vice-presidente do Sindicato, ele foi. Mais ou menos umas seis e meia, ou sete horas, já tinha mais gente. Nosso objetivo esse dia era fazer uma grande assembléia ali, e fazer uma caminhada dali até o centro de São Bernardo pela principal avenida. O dia que você andar pelo lado de lá você vai conhecer. É a linha do trolebus hoje, acompanha a linha do trolebus. Aí, pra mim foi muito decepcionante isso, porque o Joel, vendo o baixo número de gente que tinha, e o tanto de policial, chegou e conversou com o comandante da polícia, que já o conhecia como vice-prefeito. Falou: "Olha, nós não vamos fazer barulho nenhum. Inclusive até se vocês puderem mandar um carro na frente, a gente vai fazer uma passeata daqui até São Bernardo e fazer um ato público na Praça da Matriz em São Bernardo”. Me senti bastante acanhado de fazer uma greve geral tendo como abatedor a polícia na frente. [risos] Pra mim foi muito decepcionante isso. Pensei: "Não dá pra participar mais". Participei da assembléia, que terminou às duas horas da tarde. Vínhamos eu e esse colega. A partir daí não participei mais de movimento nenhum. Foi muita decepção.

Quando foi isso? 
Já foi nos anos 90. Já não estava mais no poder dos militares, era o regime democrático. Já havia algumas viaturas na frente com a sirene ligada, e nós com o carro de som atrás. Achei chato. Lá na Praça da Matriz de São Bernardo se concentrou bastante gente. Já teve o Menegueli discursando, Vicentinho, Lula, e essa coisa toda.

De greve, era basicamente isso aí que eu pude capturar rapidamente.

\subsubsection{Parte 5}

Retomando as greves, você lembra qual era a pauta de reivindicações? Como era a negociação dessa pauta?

Isso aí mudava, Guilherme, de um ano pra outro. Às vezes, em um ano, dependendo da negociação que acontecia, você eliminava alguma coisa, já estabilizando aquilo por dois anos, três anos, até cinco anos. Então aquilo saía da pauta, e com certeza outros problemas surgiam e já se encaixavam nos pontos de pauta pra se discutir nas próximas... Quando você eliminava alguns itens, com certeza, no processo de negociação, surgiam outros itens, que já se encaixavam na próxima rodada. E essas reivindicações normalmente se davam na época de data-base de reajuste da correção do salário, das perdas do salário. Estava previsto fazer uma correção por ano no salário. Às vezes era difícil acompanhar a inflação. Existiam vários fatores que enrolavam isso aí pra sumir com alguns números pra dificultar um pouco a negociação. Só que aí a gente não se baseava só em cima do valor do salário. Lógico que era importante, mas tinha muita coisa pra estar negociando. Como eu já te disse, de um ano pro outro, tinha diferença nas pautas de reivindicação. Era: eliminação de hora extra, redução de jornada de trabalho, a questão das férias. E entravam aí uma infinidade de coisas mais internas. A coisa que em geral era pra toda a categoria ia nessa linha. E de fábrica pra fábrica variava muito, de unidade pra unidade. Então tinha essas questões, tinha que negociar estabilidade no emprego. A questão da estabilidade dos deficientes, ou portadores de doenças, mesmo já estando previsto na CLT, mas pra ela ser validada na convenção coletiva, teria que ser discutida, negociada e aprovada em cada assembléia. Essas negociações sempre aconteciam. Aí veio a questão da redução da jornada de trabalho sem redução de salário, sempre foi pauta nossa de reivindicação. Uma coisa que a gente custou muito a conquistar, e isso estou falando das fábricas menores, nas montadoras já se conseguia isso com mais facilidade devido ao alto número de funcionários, talvez até o estudo desse pessoal, o interesse de outras pessoas que já viajavam pelo exterior e traziam experiência de lá, passavam pras lideranças e se tornava mais fácil fazer essas discussões e implantar. Essa questão é mais voltada pra representação legal do sindicato dentro da fábrica, que a gente falava o sindicato no local de trabalho, ou o famoso chão de fábrica. A gente demorou muito pra conquistar isso aí. Enquanto a gente não conquistava isso, a gente se beneficiava da Comissão Interna de Prevenção de Acidentes, que é a CIPA. Os eleitos eram estabilizados, então a gente era os mais visados pra fazer essas negociações. Aí entrava a questão do convênio médico, que a gente não tinha, tinha que brigar por isso. Restaurante, 
a questão de água, a questão de higiene nos banheiros, a questão de segurança nas máquinas pra prevenir os acidentes. O que fazia a gente brigar muito nessa parte de prevenção de acidente? O ritmo de trabalho é acelerado dentro da fábrica, é uma coisa automática, tudo feito assim, você imagina uma linha. Existe um nome pra isso que eu não me lembro agora, seria uma produção em série. Você faz uma operação aqui, uma operação ali, o próximo ali, o outro ali, o outro ali, tal e tal. Então fica uma coisa automática, um peão impulsa o outro peão. Qual é o parâmetro que o chefe tinha pra enquadrar o outro que estivesse atrasado? Como é uma linha de trabalho, se acumulasse em algum lugar, ele ia saber daquele operador porque estava acumulando aquilo ali. Segundo o que eles pregam dentro da fábrica, já foi tudo calculado, o tempo que se gasta pra fazer a primeira operação, dividia por maquinas, todas as operações em tempos muito semelhantes um ao outro. Ficava aquela coisa, é uma coisa ridícula, mas se tornava até engraçada: um peão pressionava o outro peão. O que estava atrás pedia pro outro acelerar, porque queria atingir a produção que está prevista pra ele. Ou vice-versa, o que está na frente, se a operação do outro anterior atrasasse, ele começava a pressionar. E chegava às vezes até, como a troca de funcionários era muito grande, chegava às vezes até a um peão dedar o outro pro chefe. Criava uma confusão danada, havia essa questão toda.

Mas as pautas de reivindicação eram sempre baseadas em cima das nossas necessidades. Veio a questão da licença da maternidade, que era bem reduzida. A gente conseguiu conquistar isso, levando pra um prazo maior. Mesmo após os noventa dias de afastamento, a gente conseguiu negociar que a mãe teria uma hora a menos por dia, ou duas, pra sair e alimentar a criança, uma vez que não tinha creche ali. Se tivesse creche ela poderia, de tempo em tempo, ir até a creche alimentar. Eu não presenciei isso porque a fábrica que eu trabalhei não tinha creche lê dentro, mas isso era também uma das reivindicações nossas nas épocas das convenções que se faziam no Sindicato. Aí entrava a questão, mesmo já estando prevista nas convenções, e já prevista na CLT, nunca se cumpria, que era a questão do desjejum. A gente não tinha, conquistamos isso. Restaurante a gente não tinha. Conquistamos isso também. Cesta básica, conquistamos isso aí também. Tudo isso entrava nas pautas de reivindicação. Depois veio a questão da licença paternidade. Inclusive, no meu caso, eu não peguei isso. Durante o tempo que eu trabalhei foi o tempo que nasceram meus quatro filhos. Só que aí a gente só tinha um dia de licença, que era o dia que você ia ao cartório registrar a criança. Trazia como atestado o registro da criança, que abonava seu dia, e já dava entrada na papelada pro salário família.

Então, variava muito, Guilherme. Lá no início, que o salário estava muito defasado e a inflação muito elevada, a gente brigava muito pela questão do poder aquisitivo. Mas depois essas coisas foram ficando, e a gente começou a trabalhar mais em cima das questões sociais mesmo, os direitos a ser conquistados. Eu não teria medo de errar nem um pouquinho afirmando pra você: o que temos de direitos conquistados na área trabalhista hoje, foi muita luta nossa. Eu não diria que foi só do Sindicato do ABC, a gente já pegou algumas partes que vieram anteriormente, algumas já não concluíam, a gente se baseava na Constituição. Até antes da Constituição de 88, tinha uma Constituição mais antiga, que eu não me lembro qual foi a última edição. E a chamada CLT previa um monte de coisas. Mas não era cumprido. Não tinha o interesse de ler a coisa toda, de verificar. Foi mais ou menos por aí. Pra gente fazer uma lista completa de todas as reivindicações... no geral é isso que eu te disse, que era 
abrangente. Mas pra você pegar fábrica por fábrica é bem complicado. Teria que aprofundar mais. A gente lembra de algumas coisas, outras não. Era a questão de garantir o emprego de um determinado percentual de deficientes. Não tinha. Eram discriminados brutalmente. Mesmo protegidos pela lei, mas as empresas se omitiam em pegar essas pessoas. Eu não sei se cheguei a falar pra você nos comentários anteriores sobre um deficiente de audição que trabalhou com a gente. Acho que já comentei isso, sim. Eu estava de férias, esse cara foi entrar. Foi até um delegado de polícia que foi candidato em uma eleição lá em Diadema, e ele costurava bem com a empresa. E essas negociações político-partidárias rumam aos afilhados mesmo, os padrinhos políticos. Foi negociar com a direção da empresa. Só que eu estava de férias na época. Em diversos setores os supervisores negaram de aceitar esse cara. Acharam que ele ia trazer muito problema. Infelizmente é uma categoria que visa só o lado da empresa, não visa o lado social. Disseram até pra esposa desse deficiente auditivo, que é um mudo: "Olha, tem um supervisor de férias. Quando ele voltar, eu vou conversar com ele. Se ele topar, eu chamo”. E isso aconteceu. Quando eu voltei de férias, no segundo dia o recursos humanos me chama: "Tem um problema assim, assim, assim. Gostaria de ver a sua opinião. A gente acabou explicando direitinho o que tinha que fazer ali, mas gostaria de estar conversando com alguém que entendesse os sinais dele, porque eu não consigo conversar com um mudo, fica meio complicado”. E acabou vindo, fiz a entrevista com a esposa dele, junto com ele ali. Já percebi que era um cara descente. Também teria que ver o outro lado. Eu teria que ter aquela pessoa na área de produção pra atingir a meta, e ter a mente voltada pro lado social. Pô, todo cidadão tem direito de vida, de produzir, de andar com suas próprias pernas. Contratamos, e ele ficou comigo uma temporada, até que meu setor foi extinto, e isso já tinha dez anos que ele estava trabalhando comigo. Transferiram pra outro setor, e ele está na fábrica até hoje, vai ficar até aposentar. Isso não é uma questão que foi uma reivindicação da categoria, mas está previsto na convenção coletiva que deveria ter um percentual de deficientes trabalhando. Ele, sendo encaminhado por um delegado que era candidato na época, até facilitou um pouco pra empresa aceitar. Me chamaram pra conversar, muito embora esse delegado é um tremendo de um sacana, fez várias sacanagens na porta da fábrica. Mas não tinha nada a ver com o problema do delegado. Eu estava vendo o lado do cidadão, com sal deficiência, que tinha o seu direito de se manter dentro da sociedade. A partir daí serviu de exemplo, essa questão do cara entrar, trabalhar, sem dar problema nenhum. A gente acabou passando essas informações pro Sindicato, e eles divulgavam que era importante que as fábricas cumprissem a lei e cedessem os espaços pra essas pessoas. E assim isso foi caminhando.

Era bastante problemático. Em todas épocas de negociação, Guilherme, se reviam as pautas de reivindicação, mas ocorriam demissões na fábrica. Porque aquelas pessoas que se destacavam mais nas reuniões, e o Sindicato errava muito nessa parte, talvez por falta de experiência, começavam a cutucar as pessoas pra elas falarem. Só que esqueciam que tinha olhômetro pra passar pra direção. Quando iam discutir ao todo, cada fábrica mandava seu espião lá dentro. Agora quando era reunião específica de uma fábrica, um grande erro que o Sindicato cometia era esse: publicava na Tribuna que tal dia, tal hora, em tal sala ia ter reunião de tal fábrica. Eu julgava isso um grande erro, inclusive me negava a ir, porque sabia que aquilo ali era pra sacrificar algumas pessoas. Então aquelas pessoas que iam denunciar as irregularidades já estavam marcadas pra na primeira oportunidade serem 
descartadas da empresa. Então essa questão das pautas de reivindicação é bastante complicada. Como eu já disse: muita coisa que a gente conseguiu, não tenho medo nenhum de dizer, as conquistas que tivemos foram através dessas lutas. Mas muitas cabeças rodaram com isso aí. Eu não sei se você queria saber de ano a ano. O geral é mais ou menos isso.

Como a gente já falou anteriormente, é muito complicado. A questão da água, a questão do restaurante, a questão da segurança. Gostaria de destacar um pouco mais a questão da segurança. Nas pautas de reivindicação a gente bateu muito em cima disso. Porque todo acidente de trabalho era julgado como um ato inseguro. Não sei se você manja desse negócio, mas existe pra determinar o maior culpado: ato que é praticado pelo funcionário, na nossa língua, o peão. E a condição seria o que a firma oferece. Normalmente quem ia fazer essa avaliação era um técnico de segurança, especializado nesse caso. Sempre, sempre você já sabe que ele puxava a sardinha pro outro lado. Sempre, sempre ele jogava isso como um ato inseguro. Aí, eu, como ocupei cargo de CIPA várias vezes, realmente eu tinha que pegar os documentos ligados à CLT, extraindo a portaria 3214, com um monte do normas regulamentadoras, tinha que sentar com ele e debater: "Olha, tem uma parte que é ato. Mas o ato inseguro aconteceu por um motivo de você não dar uma condição". Então nós conseguimos introduzir isso nas pautas de reivindicação, que inclusive nós da CIPA teríamos o poder de chegar e parar uma máquina por estar em uma condição insegura. Ou seja, aquela que permite que a mão do cidadão entrasse debaixo da ferramenta. Foram pedidos dispositivos pra eliminar isso. Isso se tornou pauta de reivindicação nas épocas de convenções coletivas. Pra gente eliminar os acidentes. Era uma grande quantidade de acidentes que aconteciam. Tais como empilhadeira sem sinalização, as prensas sem proteção, produtos químicos manipulados sem DPI, os dispositivos de proteção individual, ou até de proteção coletiva. O funcionário era dotado de boa vontade quando se prontificava a fazer coisa que não era da sua alçada. Exemplo: desarmou uma chave elétrica, pararam três ou quatro pecas. O cara apavorado, querendo produzir, ele ia lá mexer sem estar habilitado a fazer isso. Nós conseguimos quebrar isso também, só podia mexer quem estava habilitado.

Então, foi mais ou menos assim, essa questão. Muito trabalhosa. Sempre houve resistência. Toda época de negociação a resistência era terrivel. E onde eu acho que houve alguns erros por parte dos nossos representantes sindicalistas, deveriam discutir isso aí mais reservadamente. Como as empresas discutiam e discutem até hoje as suas ações mais reservadamente, pra ir pro ataque. Já o Sindicato não tinha essas artimanhas. A gente já chamou a atenção várias vezes que deveriam fazer isso aí. Tornar pública a pauta de reivindicação, mas quando tivesse que discutir separado, não ficar divulgando dia, horário e local pra evitar espiões.

Resumindo, acho que é isso aí, Guilherme.

Adão, durante as greves, como eram as assembléias e as reuniões?

Aí você diz da categoria, né?

Ou da categoria, ou dentro da fábrica. O que mais marcou pra você.

Bom, na categoria, era assim, Guilherme. Depois de fazer a reunião... Vamos falar assim, tinha uma assembléia geral onde se tirava a pauta de reivindicação. Era encaminhada e era negociada com representante da empresa, o sindicato da empresa. Já tinha esse embate entre 
a representatividade nossa, o nosso sindicato, e o sindicato da empresa, que é a FIESP, e outras coisas que eles colocam no meio. O SINDIPEÇAS, e outras tranqueiras dessas. Quando não havia acordo lá, eles costumavam jogar para as empresas. Aí foi uma esperteza que eles tiveram, que era uma maneira de dissolver o número de peões na rua. Pra eles era muito mais difícil controlar o todo que controlar os focos. O que dava pra negociar no geralzão, através da assembléia geral que o Sindicato realizava pra essa finalidade, se convocava aquele mutirão de gente, e aí aprovava. Encaminhava e se fazia a negociação. As firmas que aceitavam já assinavam o acordo, o que era muito difícil. Normalmente ali, dentro daquela assembléia, pouca coisa avançava. O Sindicato incentivava a pedir um monte de coisas, já prevendo isso, que quando levasse pra mesa de negociação da categoria toda, mesmo se reduzissem aquilo em sessenta por cento, cinqüenta, pra gente já era vantajoso. Nunca fui muito favorável a isso. Falava: "Olha, vamos pedir o que é certo e defender até o fim o que é certo. Não adianta pedir cinco pra pegar um”. É um jogo que eu não concordava muito, mas faz parte da negociação. Então o que dava pra fechar no geral a gente fechava, o que era muito difícil de acontecer. Normalmente eles usavam essas táticas: "Vamos fazer o seguinte, vamos negociar com as auto-peças, forma-s um grupo das auto-peças, e forma-se um bloco das montadoras". E lá depois de formar o bloco das montadoras ainda dividia por montadora, "vamos negociar com a Volks, vamos negociar com a Mercedes, Ford". Aí tinha que ter uma comunicação muito rápida pra um não fechar acordo que prejudicasse a negociação de outro. Digamos assim, que a Volks estava desesperada pra produzir, abria até alguma exceção e fechava, entre aspas, alguns acordos que contemplavam. Mas por outro lado eles já ligavam pra Ford ou pra Mercedes pra não aceitar aquilo, que aceitando aquilo lá, já voltava à estaca zero a negociação. E assim eles iam enrolando, enrolando, até que a gente já convocava uma assembléia. Na assembléia geral a gente já determinava um calendário. Em tal data a gente vai ter uma reunião pra dar um retorno, ver o que avançou, o que não avançou, e qual serão os próximos passos. Quando eles vinham eles apresentavam pra gente essas dificuldades, não deixavam muito claro essas manobras de dividir as empresas, e acabavam dividindo. Acabavam dividindo isso aí pra fazer as negociações. Quando fechavam acordo com as montadoras, e se comunicavam rapidamente uma com a outra, "eu aceito isso", mas ligava pra outra pra não aceitar. Aquela de lá aceitava uma outra coisa, ligava pra de cá pra não aceitar. Aí gerava um impasse que levava a gente até a realizar as greves. Já nas auto-peças, que já é um número mais reduzido, era um pouco mais difícil de fazer essas negociações, devido ao número de pessoas ser menor, e a espionagem por lado da empresa era muito maior, porque elas colocavam os guardas, colocavam a supervisão, gerente e toda essa corriola toda, pra supervisionar isso aí. Normalmente havia pressão, por ali já tinha carro de polícia circulando, essa coisa toda. Eles falavam que era em nome da ordem. Mas aí qualquer bobeada que o cara dava, quando terminava aquela assembléia, se os caras não ficassem espertos, já eram presos nas próximas esquinas por ali mesmo.

Isso aí vai fazendo com que a gente vá aprendendo. A cada dia que passava a gente ia aprendendo. Só que na hora de fechar os acordo vinha gradativamente. Normalmente a Volks era a primeira a fazer o acordo. E dela já repassava pras outras. Aí quando chegava nas auto-peças os índices eram bem menores que o das montadoras. Aí já negociavam um índice menor. Porque as montadoras já ligavam para os seus fornecedores de auto-peças e falavam: 
"Olha, nós fechamos um acordo assim e assim. Tenta diminuir o máximo que você puder no seu, porque não vou comprar o seu produto com esse reajuste. Se você repassar esse reajuste todo, você vai repassar na peça e eu não comprar mais, você vai ter que arrumar outro fabricante”. Então era muito complicado. Eu te digo assim: dirigir uma crítica ao Sindicato é fácil, mas se você se colocar lá dentro do Sindicato, você ia ver que você teria que ser um tremendo de um malabarista. Sem contar que existia, dentro do conjunto de sindicalistas, as propostas que falavam: "você abre mão disso, porque nós vamos ver essa outra parte, benefícios próprios, essa coisa toda”. Infelizmente, lá, uma vez ou outra acontecia alguns casos que a gente tomava conhecimento. A gente partia pra cima e mandava caçar o cara. Aí não tem jeito, não. Ou você representa uma categoria, ou vai correr atrás do seu interesse. Você foi eleito por uma categoria. E a coisa rolava desse jeito. Não era nada fácil, era bem complicado. Aí demorava três ou quatro meses pra você fazer um acordo. Eu sei que o último mais pesado que a gente fez foi um que a gente garantiu uma estabilidade do pessoal. Então em novembro de 2006 terminou a estabilidade que a gente tinha negociado, que envolvia até as matrizes das montadoras, pra não mandar aquela quantidade de gente embora. Agora, de 2006 pra cá eu não estou muito centralizado no Sindicato. Eu não sei como é que foi, se eles conseguiram prorrogar isso ou não. Quero crer que não. Pelo que eu vejo nos telejornais está uma maré bem escura. Começam a fechar fábricas aqui no Brasil e essa coisa toda.

As empresas sempre foram espertas nisso aí. Lógico, quem não for esperto não consegue sobreviver. Acho que nós já comentamos no decorrer das nossas conversas o deslocamento de um lugar pra outro que aconteceu, que facilitava pela isenção de impostos e essas coisas todas. Quando uma empresa se deslocava de um lugar pra outro era prevendo esses benefícios. Não era somente isso, a gente tem clareza que não era somente isso. As empresas que saíram de São Paulo, quando foram para o ABC, tinham um objetivo que foi alcançado. Terminou isso, agora começaram a soltar. Foram pro lado de Campinas, despencou pro lado do Paraná e já se espalharam pelo Brasil todo. Não só pra diminuir a carga tributária, mas também pra desmobilizar a categoria. O Sindicato do ABC se tornou uma coisa bastante desagradável pras empresas. Com as pautas montadas eles começaram a perceber que o trabalhador começou a ver muitos direitos seus lesados. Então esse foi um motivo pra eles pensarem: "Bom, vou mandar lá pra um cantão onde o pessoal nem ouve rádio direito, não circula jornal, não tem ninguém pra fazer essas reuniões”. Aí nós tivemos que fazer a discussão no Sindicato. Falamos: "Olha, deslocou uma fábrica pra um lugar, tem que mandar alguém pra lá. E já chegar e começar a trabalhar”. É o que acontece nos dias de hoje. Quero crer que nos dias de hoje está até mais difícil de fazer essas negociações. Muito embora houve um período bravo, e nós já o vencemos. Foram as conquistas que nós tivemos. Eu vejo, com muita preocupação agora, até saindo um pouco da sua pergunta, o desmonte dos direitos que nós conseguimos. Esses direitos nós não podemos nem pensar em abrir mão deles. Olha, muitas vidas se foram. Mortes ocorreram. Mortes lentas. O que é morte lenta? Aquele cara que ficou excluído do mercado pra nós está em um processo de morte lenta, porque ele não terá condições de se sustentar mais. A família dele vai começar a entrar em degradação porque não tem recursos pra se manter. Aí, dependendo da maneira da família dele, começa até a sobrar, a ser excluído da própria família. "Você já está velho e não está conseguindo arrumar mais porcaria nenhuma, você arrumou um monte de treta lá fora, está 
desempregado, agora vai ficar enchendo o saco”. Esse é um grande problema que a gente está vivendo, dá pra perceber isso nitidamente dentro da sociedade. É muito complicado.

Até aproveitando o gancho, na semana passado eu estava conversando com uns jovens, e infelizmente eu ouvi isso deles: "Pôxa, o desemprego que existe hoje, vocês têm uma parcela de culpa nisso. Porque você começaram a fazer um monte de greves no passado, e as empresas...". Eu tive que explicar bastante pra esses jovens que a coisa não é assim: "Vamos pegar todas as informações que tem, vamos ler. Você vai ver que a coisa não é assim. Você precisa ver como era o meio de produção naquela época e como é hoje. Você precisa ver quantos funcionários havia naquela época e quantos há hoje”. E aí ele ainda rebateu: "Se tem pouco hoje é porque faziam muita greve". Então é muito complicado esse negócio. A gente tem que estar explicando. Às vezes você tem que gastar um bom tempo pra conversar com esse pessoal que está desempregado hoje, que está desesperado, que às vezes eles pensam que a culpa é nossa, é dos metalúrgicos, principalmente do $A B C$, que tinha uma luta mais intensificada. Conseguiam reivindicar mais direitos. Eu acho que ainda é o mínimo, a gente está muito longe ainda dos países de primeiro mundo. Mesmo assim a imprensa é uma verdadeira assassina nesse ponto de vista. Ela consegue passar isso pra juventude. Infelizmente tem algumas religiões que também frisam isso em alguns segmentos da sociedade. Tinham que fazer uma análise melhor disso aí, pra esse pessoal não ter essa visão. Fui muita luta. Eu, quando tenho a oportunidade de conversar com o pessoal jovem sobre o porquê do desemprego, às vezes esbarro nesse questionamento, que você tem que tentar explicar pra ele como isso acontece. Acho que a gente vai acabar entrando nesse assunto daqui pra frente, quando for falar das conseqüencias das greves, as mudanças que teve.

Antes ainda de entrar nas conseqüências, você lembra de mais algum episódio, alguma história marcante das greves, que você queira contar?

Têm várias. Tem vários episódios. Um deles foi em 85, uma greve pesada que a gente teve, na unidade onde eu trabalhei muitos colegas foram presos. Muitos apanharam na porta da fábrica. E era tão ridículo que tinha o portão - naquela época não era um portão alto, hoje fizeram um muro com seis ou sete metros de altura, que aí isola mesmo. Em 85, nas assembléias que a gente fazia na porta da fábrica pra defender nossas pautas, gerava tanto conflito, que as empresas resolveram fazer aqueles murões. Hoje se você andar nas fábricas do ABC, aquelas mais antigas, você vê aqueles muros monstruosos na frente, com cabine de guarda em cima. Agora já até modernizaram um pouco, que na cabine já colocam câmeras pra filmar tudo que está acontecendo por aí, tem um circuito interno. Mas naquela época não tinha câmera, era guarda com a máquina na mão. Se insistisse um pouco, ele, com a cabeça muito vazia, atirava. E nessas assembléias a polícia chegava descendo o pau, não queria nem saber. Chegava descendo o cacete. Abria, entrava, já queria saber quem era o responsável, $e$ se a gente não estivesse bem mobilizado, os responsáveis iam presos e às vezes nem voltavam mais. E nessa questão de 85 o mais ridículo que eu pude presenciar era o descaso da direção da empresa. Durante o processo dessa greve a gente fazia assembléia, e a assembléia determinava que a gente não arredasse o pé, que a gente ficasse nas dependências da fábrica, mas sem fazer nada. Aí eles tentaram expulsar a gente pra fora, pra rua. E de vez em quando saía um comunicado. Como era a maneira de eles comunicarem? Faziam uma lista e colocavam na grade do portão, dizendo que estava suspenso o adiantamento, não iam 
colocar mais papel higiênico no banheiro, não ia ter mais água, porque não ia ter que ligasse as bombas. Tudo pressão psicológica. O médico não viria atender, porque a emprese entendia que não estava funcionando, então não teria como atender. A cozinha não iria funcionar, porque uma vez que está de greve, os cozinheiros também estão de greve. Só que a cozinha já era terceirizada, não tinha nada a ver uma coisa com a outra. Isso, pelo lado da empresa. E ela divulgava a lista das pessoas que seriam dispensadas, pra fazer pressão psicológica. Geralmente eles pegavam aquelas pessoas mais idosas, que era pra mexer com a sensibilidade das pessoas, ou até um deficiente. A gente fazia essa leitura assim: "Não tem mais barreira. Vamos começar com esses aqui que são estabilizados. A gente fazendo essa ameaça em cima desses, o pessoal vai pensar: 'Pôxa, se estão indo em cima desses que são estabilizados, imagina o que vai acontecer com os outros"”. Esse era o lado da fábrica. Agora, toda moeda tem dois lados. Nessa época não tinha comissão de fábrica. Eu estava na CIPA. Pra mim era super complicado. Além dessa pressão da organização da empresa, os colegas, parte deles, depois que a assembléia determinava que a gente ia ficar por ali, eles iam pros botecos beber. Aqueles com pouca consciência. Iam lá jogar um dominó, tomar uma cachaça, comer um salgado, e a firma já mandava alguém pra lá pra ficar cutucando. Ou seja, inflamando pra aquela pessoa começar a tacar o pau naquele supervisor, ou naquele problema da empresa. Então podia ficar tranqüilo que aquele ali era carta marcada. Então isso me marcou muito porque chegava em alguns colegas e falava pra eles: "Gente, a greve é encarada como uma guerra. E você, pra enfrentar uma guerra, tem que estar preparado, tem que estar bem equipado. Agora, vocês vêm pro boteco, enchem a cabeça de pinga, começam a comentar todas as táticas que nós estamos planejando aplicar pra pressionar a negociação, e vocês entregam isso de mão beijada através da cachaça, pra uns filhas da puta que vêm aqui cutucar vocês pra falar. E até pagar pinga!". Porque eles até pagavam pinga, eu acabei descobrindo isso. A empresa patrocinava. Estou mais falando da empresa que eu trabalhei, mas as outras, pelos contatos que eu tive com colegas, era a mesma coisa. A própria empresa liberava o dinheiro para que algum nó-cego dedo-duro fosse lá puxar o assunto. Se o cara começasse a puxar o assunto, ele começava a chamar mais bebida, beber junto. Iam jogando, jogando, pra depois trazer pra empresa. Então isso foi coisa que marcou bastante.

A ação da polícia também marcou muito. Isso era complicado. Eles chegavam e não queriam nem saber. Não vamos dizer a própria justiça. Mas como o cara estava na fábrica com a arma, depois do expediente de trabalho dele, ele ia prestar serviço particular pra empresa. Como eu já te disse dessa pessoa que apresentou aquele deficiente, era um delegado de polícia de Diadema. Ele costurava com varias empresas pra nessas épocas ele dar essas coberturas.Uma coisa ilegal, que até a gente descobrir que é ilegal, a gente tinha que ficar ali acatando ordem, tendo que obedecer, respeitar a farda do cidadão que está ali na fábrica, ferindo brutalmente a lei. Mas pra gente, que já tinha um pouco mais de consciência, não era aquela pessoa. Ele está com um equipamento, ele representa a lei. Qualquer coisa que você fizesse era desacato à autoridade. Esse era um dos grandes problemas que a gente tinha, alem de muitos que apanhavam. Firma pequena era mais difícil acontecer esses negócios assim. O pessoal se dispersava, às vezes nem reunia tudo. Exceto o que eu estou te falando da fábrica que eu trabalhei, era isso que eu acabei de colocar. A informação que a gente tinha das firmas grandes é que era pior ainda. Era pior porque tinha muito investigador à paisana lá dentro. Chegava lá com macacão, naquela época se usava 
muito macacão como uniforme, de outra firma, e falava que is ajudar a pressionar a negociação. E ali ele conseguia captar algumas informações, e já passava direto. Investigador de polícia ia fazer isso. Mas como particular, não determinado pela própria polícia. Então são alguns episódios que aconteceram. Quando apertava muito tinha as manifestações. A gente reunia uma infinidade de gente, invadia avenida, essa coisa toda. Aí a polícia chegava e descia o pau. Muita gente foi presa, muita gente morreu nesse processo, pra gente conquistar os direitos trabalhistas que temos hoje. Os direitos que temos hoje, que a gente julga que está muito aquém das nossas necessidades, mas foram conquistados desse jeito, através dessas greves. Sem greve não teria avançado nada.

Agora, acho que vale a pena ressaltar a mobilização no decorrer do tempo. Foi quando começaram a aparecer outros interesses dentro das direções de categoria. Até uma questão que foi necessária. Mas na medida que se começou a discutir isso, você perdeu um pouco a essência do trabalhador. "Vamos cercar por cima!", direto, pleiteando a criação de um partido pra representar o trabalhador. Isso pra mim foi o fim do movimento dos metalúrgicos. Pode ter pessoas que vêem isso de outra forma, mas pra mim foi o fim. Porque eu digo isso? Nessas manifestações, antes de ter essas pretensões, o número de gente que você levava pra rua era muito grande. Sessenta, oitenta, cem mil pessoas que iam fazer uma passeata. Muita coisa. Depois disso começou a esfarelar a coisa. Uma parte não concordava, outra parte concordava. Aí começaram a criar disputa interna dentro do sindicato. Começou a gerar, através desses conflitos internos, as facções dentro do sindicato, que prevalecem até hoje. Os mais radicais, os moderados, os mais conservadores. Tem aqueles que fazem as negociações com as empresas pra ver os resultados deles. A gente não tem provas concretas, mas há muitas evidências que houve algumas negociações pra chegar até esse ponto. Então acho que foi um dos entraves que a gente teve, que pra mim marcou muito nas greves. $\mathrm{Na}$ última greve geral que eu participei em Diadema, às quatro e pouco da manhã eu estava na praça de Diadema, onde se esperava que a categoria estivesse em massa. Infelizmente não foi assim. A gente teve que ter um jogo de cintura muito grande porque o aparato policial que estava lá era muito maior que o número de funcionários. Foram essas negociações, e eles montaram um esquema com helicóptero voando e filmando a gente. Andaram batendo em alguns colegas. Inclusive eu até tentei controlar a situação pra eles fugirem. Depois que botou a mão ali é complicado. Houve caso, não sei se falei em outras oportunidades, a gente tinha que trocar a roupa de um pra outro pra confundir a polícia, pra aquele colega sair fora. "Sai fora que agora se eles puserem a mão, é fatal!". Isso especificamente nessa última greve geral. Mais tarde, lá pelas sete, oito horas da manha, o Joel, que é vice-prefeito de Diadema, naquela época não era, e ex-presidente do Sindicato. Chegou e negociou com a polícia pra gente fazer uma caminhada de Diadema até o centro de São Bernardo. Foi uma vergonha muito grande. Em vez de nós trabalhadores invadirmos e irmos, fazendo o movimento todo, a polícia foi nosso batedor, abrindo alas pra gente fazer a caminhada com um pequeno número de pessoas. Chegamos na Praça da Matriz. O projeto era esse: sair um grande número do centro de Diadema, um grande número do centro de Santo André, Ribeirão Pires, e nas outras cidades vizinhas, já mais ou menos controlado pra chegar na Praça da Matriz no centro de São Bernardo e fazer uma grande concentração. Foi uma concentração razoável. Como eu te disse, houve pouca adesão. Não foi o número que a gente esperava. Pra imprensa foi um prato cheio. Caíram de pau. Dizendo que foi um fracasso 
total, ninguém estava nem aí, foi uma meia dúzia de agitadores que queriam perturbar a ordem. Fui uma das grandes decepções que a gente teve. Nessa greve de 85, a responsabilidade da gente era tão grande. Foi o ano que nasceu meu filho mais novo, que eu fui conhecê-lo com três dias de idade, pois estava na frente desse movimento. Não tinha como arredar o pé. Tinha consciência que lá no hospital onde minha esposa estava, estaria tudo sob controle. Lá na greve, muitas cabeças estavam a prêmio. Falei: "Bom, esse momento agora é crucial pra ficar aqui orientando”. Foi o que eu falei, da espionagem e dos cabeças leves que iam beber pinga pra falar besteira de pois. São coisas que marcaram.

Vou enfatizar uma outra, uma coisa mais pessoal, mas é uma coisa que foi conseqüência do coletivo, no local onde trabalhei. Eu já citei isso outras vezes aqui pra você, mas vou até reprisar isso aí. A represália que a gente sofreu referente à questão do restaurante. Comida estragada, essa coisa toda. A gente tomou uma ação, tomou a frente disso aí. A minha carta de demissão sumária ficou pronta no recursos humanos. O cara me mostrou. O chefe de recursos humanos me chamou e falou: "Está aqui sua carta de demissão sumária. Qualquer coisinha a mais que você fizer, vou te entregar essa carta”. Percebi que era só falar pra ele: "Dá", e ele dava na hora. Como é que eu is fazer com minha família depois? I a arrumar emprego aonde? Tive que abaixar a cabeça, mesmo estando estabilizado. Eu estava estabilizado. Eu tinha mais um ano e pouco de estabilidade. Mas eu sabia que pra eles era fácil. Elas dariam esta carta de demissão sumária, eu recorreria, ganhava os direitos, e ia ficar em casa. Mas pra mim não era importante eu ficar em casa. O importante era lá no local de trabalho, junto com os colegas. Fui eleito pra estar lá dentro defendendo as causas que visam o bem-estar do trabalhador, que era o conflito que a gente tinha com a empresa. Mas, a gente conseguiu administrar isso, e diria que dei a volta por cima. Não tenho medo de falar isso porque, se eu consegui administrar esse conflito e permanecer lá até me aposentar, ainda fiquei um tempo depois de aposentado, é porque a gente teve um certo jogo de cintura, uma certa inteligência pra tentar negociar, tentar recuar na hora certa, tentar avançar na hora certa. São coisas que aconteceram que marcaram, e tenho até orgulho de reconhecer isso.

Quais foram as repercussões na vida dos trabalhadores depois das greves? O que mudou? É, rapaz, aí é uma coisa bem complicada. Mas houve muitas mudanças. Quais foram essas mudanças? O contingente de pessoas desempregadas, em conseqüência também das greves, foi só aumentando. Então você passou a ter um grande número de mão-de-obra sobrando. Então o patrão tinha como escolher. Usavam um monte de requisitos, que estão usando até hoje nas qualificações profissionais.

Além disso aí, as conseqüências das grandes movimentações que havia do operário junto com o Sindicato, voltado para o interesse do trabalhador, fez com que as firmas automatizassem seus meios de produção. Então, além dela ter se especializado em explorar com mais precisão o tempo de cada funcionário pra que ele produzisse mais, ela foi automatizando seu meio de produção. Mesmo isso custando caro, e tendo um grande contingente de mão-de-obra, não seria nem necessário fazer isso, tem um excesso de gente desempregada. Talvez até sairia mais barato. Mas é muito melhor automatizar os meios de produção, porque a máquina não vai ao banheiro, não tem dor de cabeça, não pede férias. Se você automatizou aquilo ali, fica tranqüilo. Um exemplo concreto, vamos falar da unidade 
onde eu trabalhei. Nós éramos em 1.400, 1.500 peões trabalhando lá dentro. E produzíamos determinada quantia por mês. Hoje está na casa de trezentas e poucas pessoas produzindo muito mais. É lógico que com a automatização dos meios de produção houve essa queda de número. E outro fator muito questionável, que está vigorando muito bem em vários lugares hoje foi a famosa terceirização. Isso é um meio que eles arrumaram, e julgo isso como conseqüência das greves. A coisa foi a seguinte: quando você tem dez pessoas, você vai medir força de dez pessoas. Se você tem cem pessoas, você vai medir força de cem pessoas. Com a terceirização e a automatização, foi um meio que eles encontraram pra desmobilizar toda a categoria. As pessoas começaram a ver como os robôs funcionavam, as máquinas modernas. Até eu diria a mudança de produtos, que antes era tudo na base do aço, hoje é na base do plástico. Isso se tornou bem mais fácil pras máquinas modernas. A questão de preço fica mais difícil de ficar sabendo, o que seria mais viável hoje, se o plástico ou o metal. Mas entra a questão de desmantelar as organizações de trabalhadores. Como eu disse, quando você mede a força de dez pessoas é diferente de medir a força de cem pessoas. Isso fez com que eles fossem terceirizando gradativamente. Por exemplo, o médico era contratado direto pela fábrica pra dar assistência pros trabalhadores. O enfermeiro era contratado direto. Hoje não é mais. $O$ serviço de segurança, de porteiro, era tudo metalúrgico. Hoje não é, hoje tem as firmas terceirizadas que prestam esse tipo de serviço. As fábricas que tinham restaurantes, eram todos funcionários da empresa. Hoje os restaurantes são terceirizados. Então quando chega nas datas da convenção coletiva, ou seja, do reajuste do salário, de apresentar as pautas de reivindicação, fica uma coisa complicadíssima. Porque dentro de uma unidade, hoje você tem no mínimo umas dez empresas diferentes trabalhando. Quando decreta greve, só vai o pessoal que é registrado naquela unidade, como funcionário daquela unidade. Vamos falar assim, o metalúrgico da empresa tal, só vai ele fazer. O outro pessoal fala: "Não posso fazer, porque não é essa a minha categoria. Não é o meu sindicato". Então foi um dos mecanismos que eles conseguiram, que eu avalio que é uma conseqüência das grandes greves. E aí vem as propagandas hoje dos "pequenos negócios, grandes resultados”, muita gente embala nisso, com o grande contingente de desempregados que tem por aí. Então as pessoas começam a procurara essas alternativas. Não só esses segmentos, que poderia ser até viável você ter pessoal especializado em serviço de cozinha, presta serviço de cozinha, especializado em medicina, poderia até ser contratado. Além disso aí, começaram também a dividir. Antes a fábrica fabricava do começo até o fim. As peças iam todas prontas pra montadora. Ali mesmo cortavam as chapas que chegavam, o material plástico que chegava, ia cada um pra sua máquina. Mesmo injetar material, fundição de isamac [inaudível], estamparia, [inaudível], politriz, galvanoplastia. Galvanoplastia que se resume em zincagem, cromoação, nitroação, essa coisa toda, que envolve um contingente grande de mão-de-obra. Ferramentaria, manutenção. Quem trabalha no segmento de iluminação, já entrando na questão dos chicotes, as redes, os terminais que iam nas pontas. Tudo era feito naquela fábrica. Então você formava um grande contingente de operários ali dentro. $O$ que eles fizeram? Foram terceirizando. Eles pegavam até uns funcionários, conheço alguns funcionários que trabalharam junto comigo na fábrica, que foram motivados peal empresa a sair da empresa, receber seus direitos todinhos, abrir um firminha pra fazer aquele componente da seção que ele trabalhava. Mas já ia fazer aquilo ali, como ele abriu uma empresa que era dele, ele ia fabricar aquilo e vender pra empresa que ele trabalhou. A 
esperteza das empresas é tão grande, que digamos que nós dois trabalhássemos com chicote elétrico. Ela me xavecava e eu ia pegar meus direitos e montar lá em um ambiente familiar uma firma. Uma questão séria pra caramba isso aí, Guilherme, porque envolve a mulher que está trabalhando em casa, além de ela fazer o serviço caseiro, ela vai ajudar naquilo ali, pra ajudar no orçamento. Ai entram as crianças na hora que volta da escola, é tudo no ambiente familiar. O começo era assim. Aí você poderia chamar tio, tia, algum outro parente, e formar aquele bloco pra produzir e entregar esse material. Me lembro que um cara que saiu pra fazer isso aí tinha feito um estudo pra um produto específico, um chicote pra antena da moto. Naquela época estava custando, pra montar dentro da firma, em torno de cinco reais. Era o custo. A gente sempre conversava com o pessoal que fazia os levantamentos de custo, avaliava o material, mão-de-obra, espaço. Calculavam tudo quanto era direito, saía por cinco reais. $O$ cara saiu, montou esse mesmo produto, com a mesmo qualidade, vendendo isso por três reais pra empresa. Então você imagina, que além de ela ter esvaziado o espaço dela, e diminuído o número de pessoas que estariam juntas pra lutar por um objetivo comum, ela dividiu esse pessoal e conseguiu obter lucro nisso aí. Você imagina, um lucro de dois reais por chicote, você imaginando dez mil chicotes por mês, quanto que dá? Se isso não for suficiente, ela pegava uma segunda pessoa e incentivava a fazer a mesma coisa. Corria e fazia a mesma coisa. Gerou uma competitividade entre os dois. Na linha desse mesmo produto que eu te falei, custava cinco pra fazer dentro da fábrica, pro cara saía fazendo por três. Quando saiu esse outro, que montou todo o esquema, ele já chegou prometendo fabricar por dois e cinqüenta. Aí o outro que saiu primeiro, temendo a concorrência, abaixava pra dois. $O$ segundo, que montou a concorrência, já abaixava pra um e oitenta. Então o produto que custava cinco reais, com o decorrer de dois anos, caiu pra um e cinqüenta. Só que o preço final do produto que ele vendia pra montadora não teve o valor reduzido, vendia pelo mesmo valor. Então você imagina a margem de lucro que o empresário começou a ter com isso aí. E além disso isento de um monte de responsabilidade. Porque além de ele ter dividido o pessoal na questão das greves, nas épocas de convenção coletiva o número é bem reduzido, imagina o ganho que ele tinha com isso. Então hoje, a maioria dessas empresas terceirizou quase tudo. Com um agravante ainda pra sociedade e pro planeta, pro meio-ambiente propriamente dito. Nessa questão do chicote, não é uma coisa tão perigosa assim porque os resíduos são poucos. Mas quando terceirizaram a área de galvanoplastia, que entra pintura, que entram produtos tóxicos, altamente tóxicos, a fiscalização em uma empresa grande tem uma dimensão, já o fundo de quintal, as autoridades nem sabem que existem. Então isso foi gravíssimo. A poluição do solo, a poluição da água, do ar, teve um crescimento incalculável, expandiu de uma maneira monstruosa. Estou de falando isso com toda a propriedade, inclusive era uma das áreas que eu coordenei o trabalho, fazia muito trabalho de segurança em cima disso na empresa, através do conhecimento que eu obtive na empresa, quando terceirizou isso aí, eu era uma das pessoas, que junto com o engenheiro da empresa is visitar as pequenas empresas de fundo de quintal que iam prestar esse serviço. Duas empresa em Diadema, quando eu cheguei no portão principal, quando is entrar pr afazer uma avaliação do equipamento de produção, pra ver se atingia ou não as normas, eu me recusei a entrar. Falei: "Não, não. Vou voltar daqui". O dono veio que veio pra cima de mim: "Não, mas porque você vai voltar? Você não ia avaliar? Como dá pra ter uma idéia só pela frente? Gostaria que você entrasse pra avaliar, ver isso e aquilo". Fale: "Meu, pára com isso. Olha 
dentro do seu estabelecimento. É uma câmara de gás. Eu não trouxe máscara, não vou entrar nisso. Não posso entrar nisso. É uma câmara de gás, olha a quantidade de vapores que tem aí. Você olha daqui e não consegue nem ver os seus funcionários. Quando você vê, o cara está sem máscara, sem avental, sem bota, sem nada. Meu, não costuma andar nesses lugares que assassinam seres humanos, não". Fui bem taxativo com o cara. O cara ligou pra empresa e falou: "Não manda mais esse cara aqui, não". Eu cheguei na empresa e me falaram: "O que você fez? O cara ligou aqui nervoso, pra você não ir mais lá”. Eu falei: "Eu não vou, não! Em primeiro lugar, não dá pra entrar lá. Se o cara entrar duas ou três vezes vai morrer intoxicado lá, com a quantidade de gases. Eu quero é denunciá-lo pras autoridades". "Não, não faz isso, que você vai arrumar uma confusão desgraçada”. Então a coisa desgambelou desse jeito. O que acontece, essas bocas de porco, esses fundos de quintal, não têm fiscalização nenhuma. Aqui, bem próximo, na Av. Taboão em Diadema, um japonês tinha uma galvanoplastia. Cheguei, chequei o método de produção dele, inclusive tinha gente da família dele, a irmã dele é formada em química, e ele estava fazendo engenharia não sei das quantas. Mas a principal preocupação deles era fazer espionagem em cima do operador. Fui umas três ou quatro vezes nessa empresas pra avaliar realmente se poderia estar produzindo ou não, essa parte de galvanização. Quando comecei a verificar o descarte da água dele, falei: "Você está louco, meu!". Do jeito que fazia lavagem dos desengraxantes altamente alcalinos e de outras coisas, de ácidos perigosos, como o clorídrico, o sulfúrico, o cromo, que oferecem um grande risco à natureza, eram descartados pro esgoto sem tratamento nenhum. Cianeto de sódio, cianeto de potássio, que são todos produtos perigosos, eram todos descartados pro esgoto sem maiores problemas pra eles. Não tinha ninguém pra fiscalizar isso aí. Não sei como conseguiam montar um negócio desses. Não sei se as autoridades faziam vista grossa. Então acho que a degradação da qualidade de visa nossa, principalmente do maio ambiente, está muito relacionada a este fator. Aí fica difícil de dizer assim pra você: foi conseqüência das greves. Sei lá, pode ser que seja. Mas quem está utilizando estes mecanismos é um bando de bandido que não tem nem como enquadrar. Não dá pra falar assim: "Vamos pendurar o pescoço desses caras, vamos cortar o pescoço deles”. É tudo em nome da grana. Esses caras não estão nem aí. O problema deles é faturar. Aí entra essa questão: a montadora não compra direto desse pessoal. Ela compra de uma empresa, por exemplo da que eu trabalhei, que é certificada pela ISO-9000, a QS, que são instrumentos que medem o controle de qualidade de cada empresa. Só que não é divulgado isso. Eles olham os registros de onde veio aquilo, verificam se atende os especificados deles, verificam o laboratório que tem pra analisar esse produto.Mas até o ano que eu trabalhei, foi em 2005, não tinha uma preocupação de ir lá na ponta da produção pra saber como aquilo era feito. Parece, eu fiz contato com um colega meu há pouco tempo, que ainda trabalha na empresa, e parece que está mudando alguma coisa agora. Parece que esses auditores, quando chegam na fábrica, se querem ver um produto tal, querem ir lá onde esse produto é fabricado. Mas o que acontece? Quando vai ter essa visita, a empresa liga pra lá: "Esconde isso, isso e isso que tal dia está indo Fulano pra fazer uma vistoria”. Chega lá a papelada está toda bonitinha, não aparece funcionário, não aparece poluição. Se tem um problema em uma coisa ou outra, se tem um produto que produz risco, se esconde. E a coisa vai.

E eu poderia, a grosso modo, atribuir isso em nome da ganância pelo lucro. A justificativa que se passa é isso, que não poderia continuar fazendo isso dentro de uma só 
empresa porque o Sindicato faz muito barulho, provoca muitas greves. Aí dava muito prejuízo pra nação. Sem contar ainda a questão das notas frias que saem fora da tributação. Então vêm falar de rombo aqui, rombo acolá, dos caras que passam a mão lá em cima, mas existe também essas tranqueiras aqui por baixo. Mas acho que o principal fator das conseqüências das greves foi isso mesmo: a automatização dos meios de produção, a qualidade... não tenho medo nenhum de te dar essa informação: a qualidade do nosso produto perdeu mais ou menos uns $70 \%$ de uns tempos pra cá. Com o avanço tecnológico que houve, a qualidade perdeu demais mesmo. Todos os produtos que você fabricava com material de alta resistência foram substituídos por material de baixa resistência. Os próprios fabricantes já dizem: "Não é pra durar uma eternidade. Se eu for vender uma coisa pra durar vinte anos, como é que eu vou vender depois. Tem que fazer uma coisa que dura dois anos. Se durar dois anos está bom”. Só que ele não consegue medir as conseqüências. Nós não temos uma política de reciclagem. Então esses descartes acontecem aonde? Nas beiradas dos rios, nas margens de estrada. Os caras não estão medindo as conseqüências que isso traz pro meio-ambiente.

Não sei se estou complicando muito sua pergunta, mas é uma coisa muito ampla, não dá pra você resumir isso na relação capital e trabalho, emprego e desemprego. Não consigo reduzir só nisso, porque eu vejo um mal até maior que esse, que é essa questão que acabei de abordar. Se for falar das alterações que estamos tendo no meio ambiente, está tudo relacionado a isso. Você pode perguntar: "Você atribui tudo isso como conseqüência das greves?”. Acho que não é isso, não. Tem que ter responsabilidades. Isso é a ganância de poucos ter muito e muitos não ter nada. Em nome desses pouco que querem ter muito, eles não medem o que vai acontecer, não sabendo que o filho dele no dia de amanhã vai ter horrores de dinheiro, mas não vai ter água pra comprar. Vai ter horrores de dinheiro, mas como é que fica o ar que ele vai respirar? Isso é muito complicado. Hoje não sei como está a educação, que deveria estar aplicando essas matérias. Formar o pessoal pra conhecer isso aí e tentar evitar. Tenho o pessoal que estuda, os filhos, mas até onde eu vejo as matérias que eles estudam, não estou vendo muita coisa. Não adianta formar o pessoal se eles não vão ter como viver, vão morrer. Então existem essas questões todas que estão relacionadas com os movimentos. Tem outras coisas, tem outras pontas da linha pra você ir puxando pra você entender as conseqüências disso tudo. Tem outras coisas negativas, tem outras coisas mais positivas, que as conseqüências dessas greves, como já dissemos anteriormente, elas acabaram gerando linha de raciocínio que era necessário haver mudanças. Considero que foram obtidas das conseqüências das greves.

Vamos partir pro lado governamental agora. Falei das leis da CLT, normas de segurança que a gente tem. Mas todo movimento que a gente fazia, estamos nas conseqüências das greves, mas tem que citar lá atrás. Todas as greves, como nós já dissemos, tinham o respaldo positivo pro lado da empresa, pela chamada justiça. Sempre eles pendiam pro lado deles. Aí foi onde nasceu a necessidade de criar um partido operário, pra que tivéssemos representantes legais, do povo. Pessoas que passaram por esses processos que estivessem lá, nas instâncias de decisão, pra formular leis que favorecem o trabalhador. Acho que isso foi uma coisa positiva. Hoje você tem um presidente da república que veio do Nordeste, que passou por fábrica, que passou pelas repressões. Está presidindo a nação, entre aspas, porque ele tem que falar o que outras pessoas querem. A gente sabe, tenho muita 
clareza disso. O que o Lula aplica hoje não é o que está na cabeça dele, é o que mandam ele fazer. Porque eu conversei com o Lula várias vezes. Ele morou aqui, foi vizinho meu. Aquele ponto onde você desceu, aquela primeira rua pra lá, ele morou ali seis meses. Depois morou ali no Maristela, depois foi pra outro lugar. Em várias reuniões que eu tive com ele, a linha de raciocínio dele é totalmente oposta ao que ele está fazendo hoje. Agora a gente já faz algumas avaliações que a gente sabe, que ou ele faz assim, ou ele sobra. A gente chega até a avaliar que talvez fosse melhor ele sobrar, que estar fazendo tanta besteira, assinando embaixo todas as trapalhadas que estão acontecendo.

Na questão das conseqüências da greve, o que poderia ser positivo pro lado da classe operária, dos trabalhadores, seriam esses representantes eleitos, não do executivo, mas do legislativo. Formular leis que nos favorecem. Quem conhece, deixando essas questões dos parlamentares de lado, pouca coisa se fez de 85 pra cá. Não sei se você acompanha essas parte, mas de 85 pra cá, basicamente o Brasil vem sendo administrado com as medidas provisórias. Não tem decreto lei, basicamente. Às vezes o presidente abaixa um decreto ou outro, mas projetos de lei aprovados, não me lembro de quase nenhum. São todos barrados, tem que fazer as negociações, essas coisas todas. Mas só enfatizar, que é importante, que hoje não dá só pra elite definir os projetos leis. Mesmo tendo um presidente como o Lula, não dá para ele decretar, porque mesmo se ele faz o decreto, ele se complica, porque existe uma fragmentação, ou uma diversidade muito grande de representantes que estão lá dentro. Aí entra a questão operária, a questão patronal, o sindicato A, o sindicato B. Entra até a questão religiosa no meio. Cada um está lá vendo seu interesse. Diria até que é um dinheiro perdido que está com essa corriola. Foi uma abertura que se conseguiu como conseqüência das greves também. Houve uma contribuição muito grande pra destruir o poder autoritário. Essa coisa que a gente chama de sociedade democrática não tem nada de democracia ainda, na prática não é real. O fato de você poder vir aqui conversar comigo não é uma democracia total, os direitos ainda estão muito longe de ser respeitados. Mas também eu julgo que essas conquistas estão relacionadas com os resultados das greves. Isso vendo por um lado político, positivando um pouco a questão da sociedade. Não sei se você acompanhou alguma coisa na semana passada, que os jornais publicaram que o rombo que tem na previdência social está relacionado aos direitos que foram formulados na Constituição de 88. Esse pessoal lá do sertão continua passando fome. Mas a fome era pior, ninguém recebia benefício nenhum. E a partir da Constituição de 88 começou a sair benefícios a essas pessoas. Então hoje a elite atribui o rombo da previdência social de hoje à Constituição de 88, que abriu uma brecha pra estar pagando essa gente. Meu Deus do céu, dar uma esmola de 350 reais pra esse pessoal que ficou a vida toda lá no mato! Talvez até, falando de grosso modo, destruindo a natureza, por falta de informação. Existe uma parte que deformou o meio ambiente todinho com desmatamento, o uso inadequado de produtos tóxicos. Esse pessoal hoje recebe uma ajuda de custo, essas pessoas idosas que nunca tiveram privilégio de nada, nunca viveram, sempre produziam pra comer. Hoje não têm mais força pra trabalhar, a família migra pra cidade atrás de emprego, e a pessoa fica morrendo de fome lá. Com a criação dessa ajuda, prevista na Constituição de 88 , hoje se vende esse argumento ridículo, no meu ponto de vista. Também eu consigo atribuir essas coisas também aos resultados dos movimentos sindicais, das greves. Quando se criou essas leis que favorecem os trabalhadores, as discussões foram profundas. A gente não estava preocupado só em favorecer o cara que pisa no pedal da 
prensa pra cortar a chapa, nem pressiona o botão pra fechar a injetora da matéria de plástico, mas a gente se preocupou com o trabalho rural também, o cara que sempre sofreu. Então não se pode desvincular isso dos resultados dos movimentos, das greves. Por esse lado a gente vê como uma coisa positiva. Muito embora os parlamentares que estão lá, mesmo sendo de um partido que levo o nosso nome, não têm muito a ver com nossas questões. Até, falando de coisa concreta. Semana passada foi eleito o presidente do Congresso, da câmara dos deputados federais, que foi o Arlindo Chinaglia. É interessante, quando você convive com uma pessoa e não conhece bem essa pessoa. Quantas e quantas vezes eu não estive com o Arlindo Chinaglia em porta de fábrica, fazendo esses movimentos? Por várias vezes ele tomou café junto com a gente no boteco da esquina. Depois que teve restaurante dentro da empresa, a gente conseguiu com que ele tomasse café junto com a gente na empresa onde eu trabalhei. Eu nem sabia que ele era médico. Fiquei sabendo agora, que saiu o histórico dele, quando foi eleito presidente do Congresso. Falei: "Porra, tantas vezes com o Arlindo Chinaglia, não sabia que esse cara era um médico". Vai pro quinto mandato, é um cara até que bom. Mas aí eu vejo, por esse caminho. Tem essas questões que não estão relacionadas às conseqüências das greves, mas o grande contingente que há hoje de desempregados, acho que nesse ponto positivo das greves, que é o nascimento do partido pra regulamentar as leis, espero que esses caras comecem a pensar. Comecem a viabilizar projetos que melhorem a qualidade de vida. Como? Controle de natalidade, que hoje não há. Porque tem um excedente de jovens jogados pela rua? Existem vários segmentos da sociedade que acham que os métodos que se utilizam pro controle da natalidade, os métodos anticoncepcionais, por interesse de certas facções, eu diria mais na linha religiosa, quanto mais pobre tem melhor pra esses caras pedirem esmola. Então deixe que vá nascendo. Aí você começa a ver moleques pelados pelas esquinas afora, nas grandes avenidas, fazendo malabarismo na frente de carro, usando drogas. São mecanismos que essas instituições usam pra ganhar dinheiro. Como a gente disse que é positivo dos resultados das greves, espero que esses congressistas criem leis. Aí pode surgir um questionamento: mas aonde vai a democracia? [risos] É meio complicado. E aí diria pra você que, como conseqüências das greves, os maiores ganhadores foram as empresas, continuam ganhando muito. Um número pra você vê como isso avançou pras empresas. No início dos anos 80, só nas montadoras havia 140.000 empregados. Isso só nas montadoras. Esse número hoje está reduzido pra 40.000. talvez 50.000. Não tenho os dados oficiais, mas está mais ou menos nessa base. Agora, você pega de 140.000 e volta pra esse número. Como eu te disse, a qualidade do produto caiu, foi lá embaixo. O preço foi lá em cima. Quem está ganhando horrores com isso? Aí a gente fala: isso foi conseqüencia das greves? Também foi. Porque gerou um mecanismo pra que eles estudassem uma metodologia pra diminuir o número de pessoas produzindo, e então ter mais lucro. Eles estão ganhando muito. Não tenho medo nenhum de dizer que as greves trouxeram um grande resultado patronal também. Os caras faturam horrores em cima disso, talvez até mais que quando a gente fazia as greves. Hoje não tem como você fazer greve mais. Como você vai chamar uma categoria pra greve? A primeira coisa que eles vão falar: "Eu. Fazer greve? Vão me mandar embora, e eu vou viver de quê?”. É muito complicado. Isso aí, Guilherme, se você observar hoje, estamos falando das metalúrgicas, mas sabe onde vai acabar acontecendo? No funcionalismo público. Se você entrar na área de educação, saúde, segurança, vai acabar acontecendo. $O$ Estado vão afastando e transferindo isso pra iniciativa 
privada, o que é muito ruim. O último concurso público pra professor do estado foi há um ano, um ano e meio. Não vai mais ter concurso. Acho que vão abrir alguns concursos na área de educação pro município, porque municipalizou a rede de ensino. Isso eu não sei para as faculdades, mas no básico eu tenho essa informação. O mesmo está acontecendo na área da saúde. Acho que esses dado que eles estão buscando, eles devem ter buscado alguma informação da categoria metalúrgica. $O$ resultado foi muito positivo pra empresa. Então o estado faz a mesma coisa, terceiriza. Mas não podemos ser otimistas que isso não vai ser benéfico pra nó, não. O cara que vai terceirizar vai pegar horrores de dinheiro. A gente vai pagar mais pra esse pessoal, diminuindo muito a qualidade, do que se a gente tivesse pessoal concursado trabalhando. Isso será um outro problema que teremos que enfrentar.

O que sua família achava das greves? Eles apoiavam as reivindicações? Eles tinham medo que alguma coisa acontecesse com você?

Minha família sempre teve muito medo. Pai, irmãos, parentes sempre recomendaram que eu deveria esquecer isso aí. Deixar isso de lado e voltar a cuidar mais da minha vida própria, se dedicar mais à minha própria família, mulher e filhos. Eu sempre dizia a eles o seguinte: "Olha, a minha família, no meu ponto de vista, é muito maior que a família de sangue. Consigo ver que minha família é um pouco mais ampla. Seria covardia resumir a meu mundinho, seis irmãos que nós somos, meu pai e minha mãe. Não que não mereçam, merecem sim toda a atenção. $O$ que a gente pode fazer a gente faz. Mas eu não me sentiria bem, porque eu sei que as conseqüências desse comodismo poderia trazer sérias conseqüências para o coletivo no final. Como eu respeito a particularidade de cada um, peço que vocês me entendam. Me desculpes pelas faltas que eu tenho em casa. Mas não vou abrir mão disso. É uma coisa que eu pretendo continuar. Se por acaso isso trazer um problema maior, se eu tiver que ser preso, ou mesmo morto, eu não gostaria que vocês chorassem por isso. Porque é uma coisa minha, eu faço com gosto. Ninguém está me obrigando a fazer. Faço porque acredito que um dia a coisa pode mudar. Quem sabe depois dessa mudança, as famílias possam viver a harmonia que vocês querem que eu viva, dentro de uma desordem completa". Como minha família é muito voltada pra religião, eu falava assim: "Como vocês não podem somar comigo nessas lutas, então rezem por mim”. [risos] Mas não que eu seja de acreditar. Não acredito em reza, em milagre. Não sou de acreditar nessas coisas, não. Até acho que Deus deva existir, mas não sou de acreditar nisso, não. Freqüento a Igreja Católica, componha até grupo lá, mas por questões estratégicas, não é porque acredito nisso.

Minha esposa questionava bastante minha ausência. A gente tem que se desdobrar muito pra cumprir esses dois lados. Não é só a militância no sindicato ou na fábrica. Isso envolve muito mais que isso. Você tem que participar da comunidade, das reuniões, dos movimentos sociais. Senão você não tem nem base pra fazer o enfrentamento a idéias voltadas pra defesa da classe dominante. Isso nunca perdi de vista. Sofri algumas ameaças. Não de perder o emprego. Como metalúrgico, não sofri tantas ameaças de risco de vida, a não ser de duas ou três vezes em conflitos com a polícia. Mas soube sair bem dessa daí. Mas as maiores ameaças que sofri foi por conta da militância em movimentos sociais. Chegou a ter gente ligando na minha casa: "Você desiste da idéia, que pode custar a vida". Estava marcado pra gente fazer, que era prolongar uma linha de ônibus. "Cuidado que pode sair tiro. Duas horas da manhã que vocês vão fazer isso, pode ter gente armada". Falei: "Pode 
aumentar suas balas que eu também vou levar bastante no bolso". Não cheguei nem a ir armado. Sabia que era mera ameaça. Fizeram até reunião pra me convencer. Como minha mãe é muito ligada a religião, tem amizade com uns padres, um deles me chamou pra conversar uma vez, tentando me convencer: "Não seria tão interessante estar fazendo isso. É um grande desgaste, pode trazer mais transtorno, ser abandonado pela própria família”. Mas a essas alturas do campeonato eu já tinha minhas conclusões próprias, que essas pressões psicológicas não iam mudar nada no meu comportamento. Agradecia a preocupação, o conselho, "mas infelizmente não posso parar". Fiz até um questionamento pra ele: "Você estudou teologia, você conheceu bem a trajetória da história de Jesus Cristo. Como você prega que deve colocá-la em prática, acho até estranho você dar conselho pra desviar desse projeto de igualdade, de uma sociedade igualitária. A sociedade que a gente vive não é assim. Por exemplo, muita gente não tem o privilégio que você tem de ter um quarto pra dormir, uma boa cama, alguém que te leve de carro. Quando você precisa de médico, você tem um hospital de ponta pra te atender. Quando você morre, é enterrado em um cemitério particular, enquanto a gente é jogado em um cemitério público por aî”. Ele sofreu um choque. Depois deu o retorno pra minha mãe: "Deixa, ele tem isso como objetivo, deixa fazer. As pessoas têm que fazer aquilo que gostam”. Mas na verdade não é gostar, é necessidade. Pra mim foi gratificante ter atuado, e atuo até hoje, não no sindicato, mas em outros movimentos.

Mas eu tenho reconhecimento, sim, dos mais próximos. Meus filhos, por exemplo, tenho certeza que não olham com maus olhos isso aí. Algumas coisas que estão sofrendo hoje, eles sabem que alguém lutou pra melhorar, mas não foi possível mudar. Isso foi muito importante de estar trabalhando, de ter conversado isso com eles. Hoje eles têm essa consciência que, se não chegaram a ter tudo o que precisam, pelo menos a gente não foi covarde, a gente tentou fazer o que foi possível. Tanto que isso me levou a sacrificar um pouco minha própria saúde, vida. As conclusões que eu pude chegar com isso, ao ser questionado sobre esse comportamento, é que muito embora eu não tenha feito faculdade, isso era falta de formação, não só acadêmica, mas formação política. Um dos jeitos de estar proporcionando condições de o cara entender uma formação política, seria avançar um pouco na formação acadêmica. Pelo menos nessa parte, que eu não pude fazer, mas pelo menos estou proporcionando condições para que eles façam. Se eles fizerem as cagadas deles no dia de amanha, já não é problema meu. Eu proporcionei condições de eles analisarem e avançarem.

Você lembra o que a mídia publicava sobre as greves? Tanto jornais e revistas, como televisão e rádio?

Sim, lembro sim. O que mais machuca a gente nessa questão dos jornais, da televisão, essa coisa todo, é que eles transferiam a responsabilidade toda pra nós. Nós éramos os agitadores, estávamos provocando uma desgraça muito grande no país, porque travava a produção, impedia o crescimento, impedia que os países de fora investissem, porque tinha o pessoal radical, comunista. Normalmente nós éramos chamados de comunistas. Os barbudos comunistas, radicais. É o que eles mais pregavam. Eles faziam questão de frisar nos momentos críticos das greves os pequenos conflitos. No caso daquelas pessoas que estavam participando já meio alteradas, embriagadas, eles tentavam documentar aquilo com muita 
nitidez pra depois comentar: "Olha o que esse pessoal faz. São perturbadores da ordem. Se esse pessoal parasse com isso, as coisas seriam bem diferentes, porque teria mais emprego, as empresas ficariam mais tranqüilas pra administrar os afazeres, o crescimento”. Então a imprensa trabalhou muito na contramão. Inclusive pra nós, metalúrgicos, houve um momento em que chegamos à conclusão que a Globo era a principal inimiga. Pra mim continua sendo. Inclusive, nós aprovamos uma proposta que nenhum militante daria entrevista pra Globo. Num ato que aconteceu em São Bernardo nós tiramos o equipamento da Globo e quebramos. Sabíamos que aquilo ia ser usado contra nós. Com o decorrer do tempo nós fomos ganhando força, e a imprensa de pequeno porte às vezes dava algum destaque, um radialista, alguma coisa assim. Então nós fomos ganhando algum destaque. Eu lembro da primeira vez que a Folha de São Paulo documentou. O Sindicato de São Bernardo deve ter isso em arquivo. Você vê o Lula, numa foto, com uma imensidão. No dia que eu cheguei na sede do Sindicato e vi aquela foto exposta lá, chegou a arrepiar meu corpo. Falei: "Puta merda, olha que beleza! Conseguimos. Fizemos o maior líder da história do sindicato. Ninguém conseguiu juntar tanta gente como ele”. Exceto aquelas babaquices do Getúlio Vargas, no passado que não era o tempo da gente. Mas aquilo pra mim foi uma coisa fantástica. Quando você for visitar a sede do Sindicato pode ser essa foto ainda esteja lá. Aquilo ali era a menina dos nossos olhos. "Olha que liderança que pintou!". O Lula era novo ainda, tinha bastante cabelo, barbudo. A gente acreditava muito nisso aí.

Tem o lado negativo da imprensa. Por outro lado, se não são os meios de comunicação, não tinha como tornar isso público a nível de Brasil e até a nível internacional. Na época não tinha Internet, esses celulares pra fotografar nada. Eles tinham lá aquelas máquinas super ultrapassadas. Quem tinha equipamento melhorzinho eram as televisões. Como nó determinamos que a Globo não era digna de levar gravação nossa, nós tomamos o equipamento e quebramos. Deixamos bem claro pros repórteres: "Não temos nada contra vocês, você são trabalhadores. Mas a sua empresa não vai levar nada”. Mas levavam, eles têm os esquemas deles. Põe um secreto. Eles têm os equipamentos de ponta deles.

Fica até difícil falar que a imprensa foi totalmente ruim pra gente. Esse lado que acabei de dizer: vira manchete, vira matéria de jornal. Talvez nem seja o objetivo deles divulgar, mas isso era um produto que vendia mais fácil. Quanto maior a manchete, mais facilmente se vende. As informações que a gente ouvia via televisão, via rádio, distorciam muito a realidade. Você estava durante a madrugada, durante o dia, durante a noite fazendo uma coisa, e a imprensa mostrava outra. Ela focalizava os pontos que chamassem mais atenção negativamente. Os pontos mais positivos nossos eles jamais mostravam. Inclusive quando saíam resultados positivos da nossa luta, eles não publicavam que a organização do Sindicato conseguiu tal coisa, mas a empresa concedeu isso e aquilo. A empresa porcaria nenhuma, aquilo era luta nossa, que a gente fez valer.

Da imprensa é basicamente isso. Isso foi depois do desmoronamento do sistema autoritário. No auge do sistema autoritário, que foi na década de 70, não tinha jeito, Você não podia nem distribuir nada, senão o pau comia. Eu acho que já falei das táticas que a gente usava pra espalhar essas notícias. As reuniões que a gente fazia sempre tinha um livro de araque, porque se chegasse algum pescoço, você já desviava o assunto, pr anão dar muito no bico. 
A imprensa é tão depravada, que acho que você já ouviu falar, nessa época você não acompanhava ainda. Na época o Osmar Santos era o Galvão Bueno da vida. Ele dominava esse negócio de narração de jogo. Quando ele subiu no palanque junto com Franco Montoro, Ulisses Guimarães, Brizola, Lula, Hélio Bicudo, Suplicy, pra defendera as Diretas Já. Na segunda vez que ele subiu, a maior represália que ele teve da Globo... deve até ter foto disso aí ainda, o dia que esse pessoal que eu citei estava na Praça da Sé, um segurou não mão do outro e levantaram gritando "Diretas Já”. A partir daí o Osmar Santos nunca mais narrou na Globo. Os caras o afastaram, disseram que ele ficou doente. Hoje nem sei o que o Osmar Santos está fazendo. Ele era um funcionário que era o filezão da Globo. Aquelas improvisações que ele fazia chamavam a atenção, os comentários dos jogos.

Eu não tenho dúvida nenhuma. Até hoje tenho o pé atrás, não confio na imprensa de forma nenhuma. Não tem como. Pelo que eu tenho acompanhado até hoje, os donos de imprensa, seja grande, pequena ou média, pela filtragem deles só passa o que eles querem, não é a realidade. Posso falar pra você com muita propriedade. Nos movimentos sociais, nas vezes que eu dei entrevista, foram umas três ou quatro vezes, eu falava uma coisa e aparecia outra. Então eu até aderi: "Não tem acordo pra falar com o pessoal da Globo". Aí surgiu a rádio, nossa rádio do ABC. Seguem a mesma linha. Se seguir a mesma linha, não vai pro ar também. Agora, quando você vai analisar a imprensa hoje, uma coisa muito recente que você pode perceber é que pela falta de promoção política que nosso povo tem, essas questões do mensalão, dos sanguessugas, a agressividade que eles publicam isso pra denegrir a imagem de uma categoria que está no poder hoje, mas não mandam porcaria nenhuma. Eles querem degradar mesmo. Nesse ponto foi bom que se tornou público. Mas é uma coisa que vem acontecendo desde que o Brasil é republicano, desde quando foi invadido, que esse roubo existe. Eu sou desfavorável, de forma alguma, jamais. Puta que o pariu, se eu tivesse a oportunidade de chegar no Lula eu ia falar um monte. Quem fez o que fizemos no passado, pra chegar aonde chegou hoje - lógico que ele costurou com esses segmentos, senão não chegaria - jamais poderia admitir esses acontecimentos no governo dele. Teria que impiedosamente, na primeira denúncia do Roberto Jefferson, chamar o José Dirceu e falar: "Zé Dirceu, o Valdomiro está envolvido, é seu assessor direto, você está fora do ministério. Sua questão de parlamentar sai da minha alçada, quem vai ver isso é a Câmara dos Deputados, mas como homem se minha confiança você está fora, e só vai voltar se provar o contrário. Se não provar o contrário, vou exigir sua desfiliação do partido, que esse partido tem um nome: é dos trabalhadores. Não é meu nem seu, é dos trabalhadores. E os trabalhadores sempre pagaram um preço muito caro por tudo que está acontecendo. E nós chegamos aqui com uma bandeira de transparência e honestidade. Isso que você está fazendo não é nossa bandeira de luta. Então vai apurar tudo isso pra depois voltar". Veio à tona tudo isso aí, fizeram os acordos, essa coisa todo. Por isso que hoje, nas últimas eleições, não fiz campanha pro PT. Não dá pra fazer campanha. O partido está fazendo uma coisa que eu não acredito. Nossa bandeira é outra. Há colegas que questionam: "Pior por pior, é melhor nós que eles". Eu falo: "Meu, pra fazer trapalhada, deixa quem fazia”. Então, até foge um pouco do seu objetivo, mas é importante ressaltar isso. Dentro do sistema, eu acho que nenhum partido de esquerda deveria se habilitar a exercer cargo executivo. Não tem como. Espero que você viva bem mais tempo que eu, você vai poder provar, analisar isso, e mais tarde você vai poder refletir. Realmente, dentro do sistema, não tem como. O sistema é cruel. Ou você 
segue suas regras e é bem sucedido, ou desiste. Não tem como. O sistema foi feito pra isso. Tem suas linhas oscilantes, mas sempre quem ganha é o grande. O pequeno nunca levou vantagem, e jamais levará. Por isso eu defendo a extinção do sistema. E uma das formas que eu acho que poderia acontecer, seria através do legislativo. Começar e criar leis, e fazer com que elas funcionem. Inclusive impedir o que os governos democráticos fizeram esse tempo todo, que é governar por medidas provisórias. Isso pra mim está errado. Formar um parlamento, e fazer as leis pra vigorar. Ou fecha logo o Congresso, e põe um cara linha dura que vai na nossa linha. Linha dura do lado de favorecer a elite, nós já temos a triste recordação de 64 a 85. Inclusive eu sempre estou perguntando pros colegas, comento com meus filhos, sobrinhos: vejo o comportamento desse pessoal que se intoxicou com esse comportamento sistemático da linha dura, e pergunto: até quando esse ranço, esse cheiro. Vai até quando? Vai demorar, puta que pariu. Será que quando morrer todo o pessoal que viveu essa época, será que isso muda? Tenho lá minhas dúvidas. Sabe que essa coisa é hereditária. O filho se preocupa muito em seguir as doutrinas do pai, os ensinamentos do pai. Infelizmente essa questão dos militares está ainda muito viva na sociedade. Há quem diga ainda que seria bom se voltasse o regime militar. Pelo amor de Deus! Não dá pra bater na orelha do cara, porque você também não é o dono da verdade, mas machuca a gente pra caramba.

Então, basicamente, é essa a visão que tenho da imprensa.

Você ainda encontra os seus companheiros com quem você militou e fez greve?

Encontro. Sempre a gente se encontra. A gente que boa parte deles está dispersa. Um vai pra um lado, outro vai pro outro. Eu tenho companheiros que apanharam, foram presos, e chegaram à conclusão que isso foi inútil. Fica vivendo a vidinha dele num sítio hoje. Ficou tão revoltado com isso... Tem um caso de um cara que não usa luz elétrica na casa dele, não tem rádio, muito menos televisão. Ele quer cozinhar no fogão à lenha e ficar lá no meio do mato mesmo. Ele acha que é melhor assim, que tudo que ele fez pra melhorar a sociedade foi em vão.

Tem outros que já pensam diferente. Já partiram pra movimentos sociais, tentando conversar com a juventude, tentando colocar em prática o que aprendeu no passado. Às vezes de outra formas, mas passando isso. Outros que se introduziram dentro de alguns segmentos religiosos pra tentar passar as mensagens. Mas de vez em quando a gente se vê. Não que a gente tenha uma organização, em tal época a gente vai se encontrar. Mas sempre a gente troca informações por telefone. Um dia muito propício pra encontrar várias dessas pessoas é o primeiro de maio. Vai na Praça da Sé, a gente encontra esses companheiros. Não sei se você observou, os últimos primeiro de maio que teve foram o absurdo dos absurdos. A Força Sindical em um lugar fazendo sorteio de apartamento, carro e o diabo à quatro. A CUT, com não sei quantas mil pessoas na Avenida Paulista, pagando horrores de dinheiro pra artista, e também fazendo sorteio. E a gente, enquanto movimento, participando ali na Praça da Sé da celebração na Catedral. Depois a gente fazia nossa caminhada por ali. Infelizmente, a gente era surpreendido por alguns oportunistas com bandeira partidário pra tirar proveito próprio. Era contra nossos princípios. Mas é uma coisa mais coerente, é onde a gente tem oportunidade de fazer denúncias. A imprensa não dá muito destaque, porque pra imprensa é muito melhor reforçar a Força Sindical, que tem os interesses da classe patronal. Super 
interessante ela mostrar os artistas que cobram horrores de dinheiro da CUT, desfilando, fazendo show na Avenida Paulista, dizendo: "A CUT perdeu a identidade de luta. A CUT hoje á um negócio de fazer comício, fazer show. Pra desviar a atenção”. A gente não participa disso aí, não. A nossa participação, desse pessoal que tem uma ideologia mais voltada pra destruir o sistema, que sofreu na pele as conseqüências, quando a gente vai pro primeiro de maio a gente vai pra refletir mesmo. Essa é uma data que não é pra fazer sorteio ou grande comemorações, é uma data pra refletir. Quanta gente morreu por isso aí. E é uma data, que ficou sendo no Brasil o dia que era divulgado o valor do salário mínimo. Até já mudaram essa data. Eles fizeram tanta coisa, que até teve a corrida da morte do Senna, que coincidiu com o primeiro de maio. [risos]. Não sei se foi felicidade ou infelicidade, mas com a morte do Senna no primeiro de maio, com todo o carisma que ele tinha no automobilismo, conseguiu abafar o segmento do primeiro de maio voltado para os trabalhadores. Não quero dizer que alguém provocou a morte dele por isso. Foi uma corrida que eles fizeram, sabe-se lá porque aconteceu esse acidente. O sistema é capaz de tudo, não duvido que tenham feito isso pra desvincular uma coisa da outra.

Então existem umas datas, Guilherme, o primeiro de maio, o sete de setembro em Aparecida do Norte, o dia oito de maio, que é o dia internacional da mulher. A gente sempre se encontra na Paulista, ou qualquer que seja o lugar marcado. Mas aí você pega meia dúzia de companheiros de luta, faz a maçaroca toda, e não estão nem sabendo o que está passando. Mas é muito importante quando a gente senta com esses companheiros pra refletir o que a gente fez no passado, se foi útil, se não foi. Aquele bate-papo, de ser amigo, a gente tem bastante. Mas devo dizer pra você que a maioria hoje está desarticulado, exceto aqueles que se envolveram em algum movimento, em alguma coisa assim. Estão lá pra dar sua pequena contribuição. A gente conhece vários.

Pra finalizar então, Adão, o que você achou de dar essa entrevista, de lembrar das coisas? Como você se sentiu?

Olha Guilherme, me senti bem em resgatar, ou seja, registrando as coisas que eu vivi há muito tempo. Isso ainda está vivo dentro da gente. Tenho certeza que não consegui nem cinqüenta por cento. Foi uma falha, deveria ter escrito tudo isso. Mas essas informações que estou te passando não são coisas tiradas de telejornais, nem de livros, nem de textos de Internet. Tenho passado aquilo que eu vivi, que eu consegui lembrar, e passar informações de coisas vividas. De uma coisa você pode ter certeza: durante esse período todo que nós estivemos conversando, eu não busquei nada inventado, nada fabricado. Eu passei uma parte do que eu vivi durante minha trajetória como trabalhador, como operário que sou. Não vou deixar de ser nunca, mesmo aposentado. Mas pra mim foi muito bom, foi muito bom isso aí. Acho que é uma maneira de, quem sabe, daqui a alguns anos, se alguém se interessar, tornar isso... você vai escrever isso, né? Quem sabe daqui a algum tempo alguém pegar isso, ler e falar: "Mudou? Alguém já trabalhou essa mudança há muito tempo. Não mudou? Mas alguém já trabalhou há muito tempo tentando mudar, mas esse bicho é feroz, não tem muito jeito com ele, não". Se várias pessoas pegam o texto pra ler, cada um vai interpretar de um jeito. Mas o que fica bem claro de tudo isso aí é que a gente está falando de tudo aquilo que a gente viveu no dia-a-dia. A gente não pegou essas coisas em meio de comunicação nenhum. Pode até ser que você encontre alguma coisa meio parecida em alguns livros, alguns textos 
de internet. Pode ser que você ache alguma coisa que se aproxime disso que a gente viveu. É meio complicado, às vezes alguém que se dedica a escrever se interessa mais em ir no seu ponto de vista que em falar a realidade. Eu estou me sentindo muito contemplado nesse tempo todo que você está dedicando a fazer essas perguntas, ter a paciência de estar ouvindo, às vezes a gente fala além do que deveria falar. Você faz uma pergunta e acabo estendendo demais a resposta. Mas o objetivo é tentar clarear isso num âmbito maior, não resumir muito só na ação sindical, do trabalhador na fábrica. Seria isso mais as conseqüências disso. Então foi muito bom. Espero que você possa ter entendido. O que você não entendeu durante esse processo, se tiver dúvidas, a gente pode conversar no momento que você achar melhor. Não tenho dúvidas que se você for procurar nos arquivos do Sindicato, você não vai encontrar tudo isso. Porque se conta a coisa de acordo com o interesse do presidente, em cada época. Talvez se você pegar a época que o Lula foi presidente do Sindicato, e lá no começo do Jair Menegueli, pode ser que você ache umas coisas meio parecidas com o que eu te passei aqui. Mas de lá pra cá, não. Se preocuparam muito em estar com a mídia, coisa essa que a gente nunca foi pretensioso. A gente está pronto pra tentar ajudar você melhorar seu entendimento, o que não ficou claro pra você. Se você precisar de maiores informações, a gente pode estar tentando recapitular isso aí. Lógico, que apesar desse tempo todo que você se dedicou a isso aí, como eu te disse, isso foi uma passada superficial. Não dá pra ir detalhe por detalhe. São trinta e poucos anos de janela. Então não dá resumir dentro de poucas horas.

\subsection{Reinaldo}

Entrevista com Reinaldo...

Reinaldo Moreira. Eu nasci em 1923. Tenho 84 anos.

Onde que o senhor nasceu?

Nasci em Salvador.

O senhor é casado? Tem filhos, netos?

Sou casado, tenho 4 filhas. Não tenho nenhum filho. Filho homem, não. Minhas filhas todas se casaram, elas têm a vidas próprias delas. São casadas, bem casadas. Vivem as vidas delas. E isso é muito bom.

O que o senhor faz hoje em dia?

Hoje em dia sou aposentado. Sou aposentado e dou meio expediente aqui na AMA. Estou aqui desde o início. Ajudei o Lula a formar esta entidade em 1978. Ele era na época o presidente do Sindicato, e ele: "Tem muito aposentado. Não estou dando conta, não." Perguntei: "E qual é o melhor? Manda embora, ué!”. Ele falou: "Não! Vou reuni-los em um grupo, em um lugar só pra eles." Falei: "Como? Como reunir?" "A gente faz uma associação de aposentados. O pessoal da ativa fica de um lado, continua fazendo tudo que estão fazendo. E 
os aposentados vão seguir seu caminho." Eu falei: "Mas nós aposentados não temos essa experiência toda pra chegar e tocar nosso destino." "Nós vamos enfiar vocês na canoa e nós vamos ensiná-los a remar". Ele gostou. [risos] Ele gostava que a gente o repreendesse. Falei: "Caramba! Vocês vão soltar um monte de aposentados, e nós não temos essa experiência, não temos essa cancha que vocês da ativa têm”, nos anos 70... nos anos 50 até os anos 70. Aqui em São Bernardo havia mais fábricas de móveis. A gente perdia nosso tempo todo com fábrica de móveis. Tanto que aqui já foi a capital dos móveis. Já foi. Depois perdeu o título para capital dos automóveis. Até alguns anos atrás era capital dos automóveis. Agora já está meio fraco. Não é como nos anos 80, de 78 até 85. Aqui tinha uma produção de carros fora do comum. Hoje já está meio fraco. A Volks tinha 40 mil funcionários. Hoje tem o quê? A metade. Hoje tem metade, se tiver. Acho que tem até menos que a metade.

Eu cheguei no Sindicato, o presidente era o Lula. Tinha o Lula, o Rubão, Expedito, Mané Anísio, o Nelson Campanholo. E muitos outros. Alguns até já morreram. Djalma Bom, que chegou até a ser deputado federal, era também da diretoria naquela época.

E ele deu uma salinha ali no primeiro andar e falou: "Vocês vão se reunir aqui. Você faz seu expediente, vou dar uma máquina de escrever e um funcionário, para quando vocês se reunirem, para taxar os sócios para pagar ingresso. E esse funcionário vai imprimir os talões, e vocês vão cobrar uma taxa de cada um, de cada aposentado”. E nós começamos por ali.

Um certo dia, nós chegamos e estava tudo revirado, polícia ali na porta. Na sala do presidente tinha um cidadão sentado. "O que está havendo?” "O Sindicato está sob intervenção." Falei: “Nossa mãe, e agora?” Para o Sindicato tudo bem, pois eles tinham muitos anos, e qualquer dia eles retomariam as coisas. Mas nós não, nós estávamos começando. Em 78, 79. Nós fomos convidados para um seminário no Rio Grande do Sul, e falei: "Nós não vamos nos apresentar lá" "Por quê??, "Não temos dinheiro, não temos condições.", "Vocês podem escrever alguma coisa a respeito de aposentados e apresentar lá como tese". A gente não tinha estabilizado nada, não tinha uma diretoria efetiva. Era uma diretoria provisória. E eu fazia parte dessa provisória. Depois ele nos chamou lá e efetivou essa diretoria. "Olha, se formos fazer eleição, vai dar um trabalho do capeta. Quero que vocês fiquem por três anos. Vocês vão dirigir tudo. Escolham um secretário, um presidente e um tesoureiro". E foi o Franklin... o tesoureiro já morreu. E o secretário era Rudi Elias. Então ficou: o Franklin era um, o Rudi Elias era dois, o Antônio Raimundo era três, o José Salgado era quatro, e eu era número cinco. A minha matrícula consta aí até hoje. [pega sua carteirinha da AMA, para mostrar que é mesmo o número cinco] Matrícula... aqui no meio, dá pra ver? São 22 mil pessoas hoje, e eu sou o número cinco. Pra você ver há quanto tempo estou batalhando em prol dos aposentados.

Aposentado é uma luta inglória, rapaz! Você não consegue muita coisa. Há quantos anos a gente vem batendo, batendo, batendo.

Depois de todas as peripécias, o Lula deixou o Sindicato, e disse: "Vou descansar, por enquanto. Talvez eu vá para a política”. Ele já tinha sido preso. Foi libertado. Foi até esse senador, de nome Romeu Tuma. Foi quem prendeu ele. Ele até outro dia falou no senado. Ele é uma cara positivo, fala a verdade. Ele disse: "Ele foi meu hóspede, o presidente foi meu hóspede". [risos] Ele era delegado do DOPS, e vinha noite e dia, noite e dia, até que ele pôs a mão no Lula, e o prendeu. Era a ditadura naquele tempo. "Vocês têm 
que prender esse cara. Ele está falando demais, e precisamos colocá-lo no xadrez". Batalharam, batalharam, até que o prenderam.

Depois, nós falamos: "A salinha está muito apertada, não dá para nós." Tinha uma casa velha aqui em um terreno do sindicato. Ele falou: "Vou dar essa casa velha e vocês se viram lá." E agora? Isso era nosso segundo mandato. "Vou dar aquela casinha velha. Vocês aqui... fica chato. O pessoal da ativa não olha nem na cara de vocês. Vocês não estão sendo bem vistos aqui. Vou dar um lugarzinho só para vocês." O Vicentinho já era o presidente. Já não era mais o Jair Menegheli. Depois do Lula foi o Jair Menegheli, e depois o Vicentinho. Ele falou: "Reúna o seu pessoal aqui na minha sala que você vão ser mudados daqui. Vão sair do Sindicato". Nós continuamos como sócios remidos. Recebemos um comprovante uma vez por ano. E cada ano tem que trocar, tem que ir lá no segundo andar, levar a carteirinha vencida, e dão uma nova, por mais um ano. Sempre assim, sempre renovando. E nós continuamos sócios do Sindicato. Tomar parte em congresso. Mês passado eles fizeram um acampamento em Brasília e foram dois ônibus de aposentados.

E nós viemos aqui [a entrevista foi realizada na atual sede da AMA, a qual Reinaldo de refere]. Começamos com uma casinha velha. Fomos ajeitando, ajeitando. Derrubamos metade da casa que estava caindo. Construímos. Derrubamos outra metade. Terminou o mandato da diretoria e veio outra diretoria. Agora, essa já está há cinco anos, essa diretoria. O Wilson com essa diretoria nova. Te mostro um quadro que tem lá na entrada. Você viu um quadro que tem lá na parede?

Não reparei.

É a diretoria que fez essa construção aqui. Está tudo bem gravado, tudo em quadro de metal, para não enferrujar. Inclusive eu também fazendo parte do departamento de... suplente de... [longo silêncio] conselho fiscal. Suplente de conselho fiscal.

Eu já ocupei cinco cargos aqui. Já fui primeiro secretário, segundo secretário, suplente de departamento jurídico, ajudante de departamento jurídico. Já pintei e bordei. Eu tenho vinte e tantos anos aqui. Às vezes eu vou, passo fora uns quinze dias, faço uma excursão. Uma pessoa da minha idade não pode ficar só viver de trabalho. Fui para Serra Negra, fui para Angra dos Reis duas vezes. Fui para Maceió, fui para Pernambuco. Fiz uma porção de excursões. Sempre dez, quinze dias no máximo. Voltava e vinha trabalhar. E continuo aqui até hoje.

A pessoa fala: "Pô, você tem 84 anos, como é que vai todo dia trabalhar e volta?". Enquanto Deus me ajudar, vou fazer tudo isso que eu faço. Danço no meio deles aí, tem baile aqui a cada quinze dias. O Sindicato empresta o salão grande que eles têm no terceiro andar. Fazemos o baile. Sábado mesmo fizemos um. Começa às seis horas, e meia-noite mais ou menos se encerra tudo para cada um ir embora para suas casas.

Reinaldo, sobre as greves dos metalúrgicos, o que o Sr. Lembra? O que pode me contar? As greves... Na época era ditadura, e os sindicatos eram muito visados, principalmente esse aqui do ABC. Não sei se havia motivo. Porque era muito combativo, então os militares ficaram muito de olho neles. Não sei se tinha algum agente aqui infiltrado, não sei dizer. Mas ficou conhecido em Brasília, pelo comando maior, que tinha um Sindicato, que tinham uns elementos no $A B C$ que estavam querendo voar. Eles falavam assim, usavam esse termo. 
Então era muito visado o Sindicato aqui. Era polícia para cá, era o DOPS toda hora passando em frente, buzinando, elementos à paisana. Nas reuniões havia detetives. Era muito visado porque era muito combativo. O Lula era um cara... não era formado. Não era formado como vocês que fazem faculdade, que ficam prontos para assumir qualquer coisa. Não, ele não era. Ele veio também de dentro de uma fábrica. Era aqui na Vergueiro. Era na... Brasmotor? Não. Fazia peças de navio. Era na... Ele era um bom torneiro. Como era o nome? Eu esqueço. A idade já não está dando mais. Ele fazia peças de navio. Quando ele veio pro sindicato foi acidentado, ficou afastado. Cortou o dedo em um torno. Perdeu um dedo. Como era o nome da firma, meu Deus? Eu sei que ele tinha, ele tem, uma cabeça muito boa. Depois ele estudou e se formou. Mas antes mesmo de ele se formar, ele tocava esse Sindicato como ninguém. No Brasil havia poucos presidentes de sindicato igual a ele. Era um fenômeno. Era fora de série. Chegava nove horas, dava um tapinha no ombro. Mexia com um, mexia com outro. Passava no meio de todos nós e ia lá para a sala dele. E o dia todo era telefonema. "Quero falar com o Lula, quero falar como o presidente! Quero falar com o Lula, quero falar como o presidente!”. Era o dia todo, rapaz. Até que em 80, eles formaram um partido político, o PT. Aí o negócio não teve mais sossego. Virou um entra e sai que não tinha tamanho. Vinha gente do Rio Grande do Sul, de Brasília, de toda parte. Aquele que morreu estava sempre aí, o Ulisses Guimarães, aquele cara de Alagoas, Teotônio Vilela. Esse senador do Rio Grande do Sul estava sempre aqui. Aquele que morreu em Pernambuco. Foi governador três vezes de Pernambuco. Você não sabe o nome dele, né? Morreu no ano passado.

Não me lembro também.

Era uma pessoa muito conhecida.

Ah, é o Miguel Arraes.

Miguel Arraes! Ele vinha sempre aqui também visitar o Lula. O Lula era muito querido. Só que a ditadura queria acabar com ele. Não ia com a cara dele. Além de prender, ele ficou fichado como mau elemento. Eles davam um nome gozado. Não era agitador, era outro nome. Tinha um nome que eles davam para o Lula. Não era quinta coluna, não era agitador. Mas era mais ou menos como uma pessoa agitadora. No fundo era um nome de uma pessoa que sabia aglutinar, sabia juntar pessoas, tinha o domínio da fala. Ele sabia fazer discurso muito bem. Mesmo sem ter um estudo profundo, ele chegava no pessoal, naquela multidão, ali no terceiro andar, pedia silêncio e todo mundo obedecia. Ele tinha um dom para falar, para conversar com as pessoas. E me parece que foi essa maneira dele de se expressar, essa oratória dele, que chamou a atenção dos militares. Ele não era de promover quebra-quebra, anarquia, nunca foi. Ele gostava das coisas direitas. Ninguém tirava um centavo que não passava por ele. O tesoureiro assinava cheque de qualquer pagamento, de qualquer compra, junto com ele. Veio um interventor quando o prenderam, que fez um levantamento, mandou buscar até aqueles caras... contador. Até contadores, para ver se conseguia fazer alguma coisa contra o Lula. O cara é terrível, não tem uma falha na presidência dele. Todas as contas em ordem. Eles fizeram de tudo para... para ver se prejudicavam? Não era o termo certo. Para ver se o pegavam no contrapé. Eles ficam conversando com você, puxando você, mexendo com você, até você falar alguma coisa que interessa para eles. É uma coisa mais ou menos assim, nesse sentido, nessa direção. Veio contador, fizeram levantamento de conta, de 
tudo. Não acharam nada. "Olha, o cara dirige isso aqui com mão de ferro". O que é mão de ferro? Não tem falha. Se o cara tirou alguma coisa ninguém nunca vai descobrir. Não é que não vai descobrir. Não tem de onde descobrir nada, porque ele era de fato um cara maravilhoso, notável. Sensacional. E foi essa qualidade dele que chamou a atenção dos militares. Ele não era queridinho. Não era querido lá. Não conseguiu se meter no ambiente. De vez em quando ele dava uma cutucadinha, claro. A ditadura fazia muita coisa errada. Quando ele se reunia com os metalúrgicos, ele falava: "Olha pessoal, está acontecendo isso, isso e isso em Brasília”. Na ocasião em que estavam vendendo os imóveis do Brasil, chamou os metalúrgicos para se reunirem aí dentro e passou tudo a limpo, o que estava se passando no Brasil. Ele era uma pessoa assim.

Cada vez que ele fazia isso, acho que tinha gente ali disfarçada, e o prestígio dele diminuía com os militares em Brasília. Cada vez que ele se reunia em uma praça, em algum lugar, eles ficavam sabendo em Brasília. Eles mandavam alguém com um aparelho e gravava. Não sei dizer, não tenho conhecimento desses troços [aparelhos gravadores]. Mas que ele não tinha prestígio com a ditadura, não tinha. Trabalhei muito tempo, no tempo dele. Eu já era aposentado e ele estava na ativa. Demorou para ele se aposentar. Ele fez requerimento algumas vezes e não foi aceito. Quando foi aceito, ele já era deputado federal. Quase quando ele ganhou a presidência que ele foi efetivado como metalúrgico aposentado. Ele recebe como anistiado, como pessoa anistiada. É um aposentado especial. É um anistiado. Consta no documento dele: anistiado. São pessoas que perderam muita coisa. Não conseguia emprego. Se chegasse um uma metalúrgica, os caras mandavam ele voltar na hora. Ficou manjado. Não tinha outro emprego. Então quando ele chegou ao Congresso, tomaram conhecimento do caso dele e anistiou. E essa palavra consta em letras grandes no documento dele: anistiado.

O senhor participou de greves?

Participei um pouco.

O senhor pode contar como foi sua participação?

Na primeira greve eu trabalhava, em 80 . Em 77 eu já me aposentei. Eu tive um problema de saúde lá dentro da Volks. Eu trabalhava em uma fresa do eixo comando, na produção. Uma fresa grande, alta. Eu fazia o eixo comando, na usinagem. Trabalhava na usinagem em um fresazinha alemã. Eu tinha algum conhecimento, pois eu trabalhava na motores PEC. Então quando eu fui para lá já não tive problema.

Quando foi 77 eu tive um problemazinho de saúde. Eu já recebia o tal "pé-na-cova". Parece uma piada, né? (risos) Mas os metalúrgicos chamavam, não sei por que, quando a pessoa completava 30 anos de trabalho, fazia um requerimento no INPS, por intermédio do departamento jurídico, eles pagavam uma pequena porcentagem, 20 ou 25 por cento, sobre aqueles 30 anos. Então quando eu fui mandado embora, em 77, quase início de 78, eu peguei os documentos, recebi a indenização e fui lá falar para os advogados: "Olha, eu estou sem nada agora. Não tenho nenhum dinheiro. Como vou sobreviver daqui para frente? Os $25 \%$ dos 30 anos já foram embora”. Falaram: "Ah, não tem problema, não. A gente passa aquela provisória, aqueles 30 anos, coloca mais um resto de anos que você tem, e você vai ser efetivado como aposentado". Era um advogado de nome Dr. Décio. "Me dá alguns dados". 
Dei. "Quando você foi dispensado?", falei: "Mês passado". "É aquela aposentadoria de 25 anos que eu requeri para você", eu tinha 30 anos na época, "agora eu vou passar essa aposentadoria provisória para efetiva. Você vai ser efetivado como aposentado. Daqui para frente você não trabalha mais, não precisa trabalhar." Eu ainda andei trabalhando em escola, escolinha. Tinha um "Santinês", não sei se você escutou falar. Era uma escola de... não era uma "madureza", não. Era uma escola de primeiro e segundo graus. Ali na Silva Jardim. Você é de São Bernardo?

Não, sou de São Paulo.

É ali na Silva Jardim. E um dia o Lula me chamou e falou: "Reinaldo, você não quer mandar uma... tem um pedido aqui para mandar dois fiscais, dois inspetores de alunos." "Eu acho que vou eu, Lula." O Lula me falou: "Você vai lá em São Paulo, na Praça João Mendes, lá na Liberdade, e vai fazer ficha para trabalhar conosco aqui em São Bernardo". Falei: "Mas eu sou aposentado." "Não tem importância. Aqui no seu documento fala que você pode voltar quando você quiser". Peguei o documento, mostrei para ele e falei: "Olha, eu sou aposentado." "Não tem importância. Você vai pagar aposentadoria como se você estivesse começando". Fiquei lá uns quatro ou cinco anos. Quando saí eu fui ao INPS e nós dividimos o dinheiro. O INPS ficou com uma parte e eu me deu a outra. Hoje você pode voltar a trabalhar, mas quando sair não recebe nada. O que você pagar, morreu. E não consta também em documentos, em seu benefício. Também não consta. Não sei como é que é, no Brasil acontecem essas coisas. Não sei.

Outro dia perguntei para o departamento jurídico: “Ainda tem pé na cova?” Não, não tem mais”. Quem voltar a trabalhar agora pode pagar o INPS normalmente, pode até fichar o documento. Mas quando parar, não recebe de volta aquele dinheiro. Pecúlio, me deram esse nome de pecúlio. Eu fui lá, levei o comprovante de todo tempo que eu tinha trabalhado, de quanto eu ganhava, fizeram as contas e me deram. Saí com os bolsos cheios de dinheiro. Uma agência ali na Marechal, passei por lá, abri uma conta e deixei lá. Uma conta-poupança no Banespa.

As greves! Eu lembro de uma que foi meio violenta. Encheram de polícia aí. Nós estávamos começando a Associação do Aposentados, que é essa hoje. Haviam uns policiais sentados lá dentro. Eu cheguei, quis voltar, e ele falou: "Não, pode entrar, pode fazer o que você costuma fazer, rapaz!”. Eu olhei a porta da sala, e o cara sentado lá. "Pode sentar, fazer o que você costuma fazer. Para você, não há impedimento nenhum. Só o pessoal do Sindicato que não pode entrar aqui, mas você aposentados podem".

E não outra, de 80, não podia se reunir em lugar nenhum. Aí o padre deu aquele salão atrás da igreja, na greve de 80. Deu uma salão atrás da igreja para o pessoal se reunir. A cada dois dias tinha uma assembléia atrás da igreja. A Igreja Matriz. O Lula ia lá, fazia a assembléia. Eu morava na parte de baixo, ali. De manhã eu levava duas garrafas térmicas de café para o pessoal tomar. Na ocasião, acabou o dinheiro dos metalúrgicos, e eles estavam angariando dinheiro para dar para aquelas famílias mais necessitadas. Os metalúrgicos ganhavam um pouquinho mais, mas também gastavam bem mais. Então, quando a greve deu uma semana, quinze dias, o pessoal começou: "Vamos voltar a trabalhar. Não agüento! Na minha casa está faltando tudo!” A gente então fez uma campanha e começou a angariar geralmente mantimentos não perecíveis. E aí eu ia lá ajudar a pesar, ver quantos quilos, o 
tamanho da família, quantos elementos tem na família, quantas crianças, quantos adultos. Eu que fazia aquela fichinha, rápido, com a mão, e ajudava a pesar mantimentos e entregá-los. Nós tínhamos duas Kombis e íamos entregar nas casas das pessoas.

Esse velhinho aqui... tenho 84 anos. Se eu não morrer daqui até o fim do ano, já viu. Danço, nado, gosto de passear, vou à praia, faço tudo. Mas acredito que uma hora ou outra isso acaba, acaba tudo. Eu não acredito mais muito em mim. Um carro novo, o motor é uma beleza. Você não vê sinal disso, sinal daquilo, não precisa de conserto, não precisa de nada. Hoje eu estou todo dia no médico, cara. Nós somos como um motor: as peças vão se desgastando, estragando, ficando velhas, se deteriorando. Assim são as pessoas. Eu pulava uma mesa dessas [mesa que estava na sala onde a entrevista foi realizada], hoje não faço nem metade. Não consigo. Gostava muito de futebol, jogava futebol. Comecei com futebol na Bahia, na praia. Morava de frente para o mar, aprendi a jogar um pouco lá na praia. Depois nos campos por aí. Quando cheguei aqui em São Bernardo, tinha uma firma metalúrgica, era a Companhia Brasileira. Era o melhor ordenado aqui. Falei: "O que eu vou fazer? Não vou nem lá pedir serviço". Aí conversando uma noite em um barzinho, falaram: "Aquela firma lê tem uma coisa: só entra quem sabe jogar futebol. Quem não souber jogar futebol não precisa nem passar em frente. Os guardas não deixam". Aí insisti, insisti, falei: "Quero fazer um teste lá. O dia que vocês forem treinar eu vou com vocês." Você está insistindo, então quintafeira você vai. Quinta-feira, três e meia da tarde. Dá para você vir?" "Dá.". Treinei, na semana seguinte mandaram me buscar em casa. Eu fiz a ficha lá, e vi que o cara do departamento de pessoal perguntou ao gerente: "E o ordenado que a gente vai fazer para esse homem aqui?" "Ah, faz o teto aí para ele". Eu tinha visto o cara treinando na quintafeira.

Que firma era essa?

Companhia Comercial Brasileira. Uma firma inglesa. Faziam peças de carro. Austin. Foi a primeira firma de automóveis aqui de São Bernardo. Depois veio a Synca do Brasil. Aquela foi à falência, depois fui pra Synca do Brasil. Ali onde hoje é aquele depósito grande das Casas Bahia. A Volks também comprou uma parte. Quando a Synca faliu, a Volks comprou tudo. Montagem de caminhou aquilo ali. Depois comprou outro lugar e foi montar caminhão fora de São Bernardo. E ultimamente tem as Casas Bahia.

Em quais firmas o senhor trabalhou?

Trabalhei na Motores PEC. Comercial Brasileira foi a primeira, Synca do Brasil, Mercantil Suíssa, fábrica de bicicletas, e a última foi a Volkswagen.

E o que o senhor fazia nas fábricas?

Eu trabalhava em usinagem. Eu fresava o eixo comando. Eram trezentos, quatrocentos por dia. Quando dava sete, oito horas, já estava cansado de tanto fazer esse movimento. Não era fácil, não.

O que o senhor lembra do trabalho na fábrica?

Da fábrica eu lembro... O horário era das seis e meia até quatro e meia da tarde. Tinha um cronometrista, cronometrava meia dúzia de peças. Durante oito horas saía $x$, a quantidade 
era essa aqui. Vinha a empilhadeira com o material, deixava ali do lado. Aí você pegava e já colocava ali na máquina. Depois das oito horas, vinha um cara da inspeção, inspetor de qualidade, e contava. "Está perfeito". Às vezes eu terminava cedo, mas quando eu saía, entrava meu companheiro. Eu tinha medo de prejudicá-lo, pegava umas coisas, ficava enrolando ali, para não fazer muito a mais, para não prejudicar o outro. $O$ outro era fraquinho, magrinho. Eu fazia oito horas e ele fazia oito horas. Um fazia oito horas de dia, e o outro fazia oito horas de noite. Quando eu fazia oito horas de dia, ele fazia oito horas de noite. Na mesma fresa, e o mesmo serviço. Tem um padrão nessas coisas. É padronizado,o serviço é sempre igual.

Parece que é rotina, mas não é, não. É um serviço bonito. Eu comecei a gostar. Todo mundo falava da Volks: "Lá tiram o couro das pessoas". Mas eu falava: "Eu estou com 41 anos, preciso pegar uma firma dessas boas”. Faltavam alguns anos ainda para me aposentar. Meti a cara e consegui um emprego lá.

Eu lembro de uma passagem. Tinha muita gente que chegava com cartão, carta de vereador, político, de prefeito. Entregavam lá e falavam: "Fica desse lado aqui, rapaz. A pedido de fulano de tal”. E eu que fui por minha conta, para mim não ligaram, não falaram nada. Uma certa hora estava todo mundo lá: "Vocês vão começar a fazer ficha amanhã". Veio um lá: "Quem veio apresentado por alguém de lá de dentro, ou alguém de lá de fora? Levanta o braço." "Eu, eu, eu." "Passem para o lado de lá. E quem veio por conta própria, com a cara e a coragem, passa para o lado de cá”. Eu fui, não apresentado por ninguém. Na minha cabeça eu precisava trabalhar, e fazia questão que fosse uma firma boa. Firminha pequena tinha um monte ali. Faltavam dez anos para completar minha aposentadoria, ou oito anos. Queria uma firma boa. Entrei lá, e só saí quando me aposentei. Eu estava meio fraquinho, com uma doença nos nervos. Ficava de pé e sentia uma espécie de uma fraqueza. Fui aos médicos, tirei chapa, "ah, não tem nada, não tem nada”. Mas eu sentia. Com 53 anos eu encerrei. Já estou há trinta anos fora, trinta anos aposentado.

O senhor fazia parte de algum movimento de bairro, ou movimento ligado à igreja?

Não, não fazia. Eu era muito dorminhoco, gostava muito de dormir cedo. Então eles não me escalavam. O pessoal do Sindicato falava: "Ah, você dorme muito cedo. Tem um negócio bom, mas não vou te escalar. Você vai ficar aqui durante o dia conosco, dando expediente aqui, atendendo o pessoal, ajudando na secretaria, atendendo o pessoal no balcão. Mas quando for para fazer essas coisas...". Quando dava cinco horas, eu saía meio devagarinho e ia embora para casa. Não era contra nada disso. Colaborava. Eu ia nas portas de fábrica, entregar jornalzinho do Sindicato, na hora de almoçar. Fazia tudo durante o dia. Mas quando dava quatro e meia, cinco horas, já me despedia. "Pessoal, até amanhã". "Já vai?" "Já". "Amanhã você vem?" "Venho, venho. Oito horas estou aqui".

Ficava lá no primeiro andar. Tinha a secretaria. Almoçava ali mesmo, no quarto andar. Trabalhava na Associação, que eles me deram uma sala no primeiro andar. E ajudava na movimentação do Sindicato. Mas quando precisavam de uma equipe boa para fazer qualquer movimentação diferente, falavam: "Ah, você é muito dorminhoco. Você não vai". "Ah, tudo bem".

Voltando às greves, você lembra quais eram as reivindicações? 
Geralmente era ordenado. Só se falava em ganhar bastante. A conversa lá dentro era: "Estou ganhando pouco, estou trabalhando muito". Todo dia tinha reclamação. "O meu chefe está pegando no meu pé, o inspetor está pegando no meu pé”. Era reclamação de todo tipo, rapaz. Nossa Senhora! "A comida está ruim!” Era uma hora de almoço, aí cortaram, ficou 45 minutos. Era processo atrás de processo, um atrás do outro. Era uma loucura esse Sindicato! Agora está meio parado. No meu tempo tinha muito mais movimentação. Tinha um departamento médico enorme. Agora tem uma enfermeira e uma médica ali na esquina. $O$ primeiro andar inteiro tinha só médico e dentista. E não dava conta do tanto de gente que vinha nesse Sindicato.

Eu conheci Lula de presidente, Jair Menegueli, Vicentinho, esse que está agora na previdência social, o Marinho, Guiba. Interventor, conheci dois. Um era de São Bernardo, o outro de Brasília. Houve duas intervenções fortes aqui, no tempo do Lula. Ficaram não sei quanto tempo. Em uma ele se saiu bem. Na outra ele foi para na cadeia.

O senhor chegou a participar de assembléias e reuniões durante as greves?

Estava em todas elas, na Vila Euclides. Participava. Não perdia uma.

Como que eram, o senhor lembra?

Nós enchíamos aquele campo, na Vila Euclides. O Lula que marcava. "Amanhã, todo pessoal, às dez horas aqui! Tal dia, duas horas da tarde!”. Todo mundo ia. De todas as firmas que estavam paradas. Iam lá, conversar com ele. Ele subia naquele palanque improvisado. Só que havia fiscais, uns guardas que ficavam dando proteção a ele. Tinha um corredor para ele passar. Quando ele ia entrar no palanque, tinha uns elementos de confiança. Só ficava lá dentro o pessoal de confiança. Eram como se fossem uns guardas. Ele tinha proteção dos metalúrgicos. Era uma boa proteção.

Mas tinha assembléia toda semana. A cada dois dias. Ele não deixava a coisa esfriar. Marcava, convocava, e todos nós íamos para lá, na Vila Euclides. Dentro do campo. E o avião passava lá em cima, olhava de lá de cima. Colocavam holofotes. Faziam aquela pressão terrível. Mesmo assim, não evitavam. Toda a moçada, todas as firmas que estavam paradas iam lá na assembléia. Grandes e pequenas. Aí saía de alma lavada no fim da tarde. O chefe falou, já deu as explicações, já deu as orientações do que vai ser feito amanhã, do que vai ser feito depois de amanhã. Voltavam com todo o respeito, sem briga, sem encrenca. Nada de jogar pedra em vidraça. Não tinha nada disso. E cada qual ia para as suas casas, sem bagunça. E ele pedia também, quando ele fazia o discurso. Nada de bagunça, nada de provocação. Não mexa com nada de ninguém. E todos obedeciam. Ele tem o dom. Chamava e conversava. E todos entendiam bem. Ele fala um português claro. Ele é meio fanhoso como eu, mas ele fala um português limpo. Falava, e todos obedeciam. Ele era um líder. Ele nasceu... eu digo assim: o cara, quando nasceu para ser uma coisa, para onde ele for, aquilo vai e algum dia acontece. Ele era líder. Ele tinha uma liderança perante os metalúrgicos de São Bernardo que era coisa fora do comum. Fora de série mesmo. Nasceu para a coisa mesmo. Não é à toa que um dia chegou à presidência da República. E repetiu o mandato. Ganhou bem. Foi quatro anos, mais um agora. Cinco anos. Se não o pegaram e mandarem embora, ele vai até completar oito anos de mandato. Um operário da Vilares... Ah! Agora eu lembro. Vilares! Torneiro da Vilares. Uma firma que fazia peça de navio. No Vergueiro, ele 
trabalhava. Na hora do almoço, os colegas falavam que ele subia em cima das coisas $e$ falava: "Olha, vou fazer um discurso. Vocês fiquem escutando aî". Ele gostava muito de tirar um sarro dos outros. Era brincalhão. Gostava de dançar. Uma pessoa absolutamente normal. Eu não sei nem como é que ele está hoje. Porque hoje ele não faz nem o que ele quer. Mandam ele fazer isso. Os juízes e promotores mandam ele fazer aquilo outro. Ele gosta de andar sem gravata. Não pode mais, tem que ser com gravata. Aí já colocam gravata nele. Ele hoje está vivendo como um manequim. Os caras chegam nele e falam: "Você vai para Brasília. Você vai para a Argentina. Tem não sei o quê lá no Hugo Chávez. Tem não sei o quê lá na França”. E hoje não se governa. Ele trabalha para os outros, trabalha para o Brasil. Não é que pode acordar, escovar os dentes, tomar o café e falar: "Não vou trabalhar hoje. Não vou em tal lugar. Vou arrumar o carro e vou à praia”. Não. Acabou a vida dele. Ele tem que seguir aquele cronograma. Hoje é dia disso, amanhã é dia de não sei o quê. É bom, mas ao mesmo tempo o camarada perde a liberdade.

Sobre as greves ainda, tem mais alguma coisa que o senhor lembra e queira contar?

Nós vínhamos aqui espiar se havia policiamento na porta do Sindicato. Nós vínhamos, mas só não podia parar ali, se não o cara te intimava. Aí passava direto, fazia a volta ali por baixo. Voltava, subia, passava em frente. E lá a polícia, com metralhadora, cachorro. Tem de tudo lá na porta do Sindicato. Mas você deve pegar outros colegas. Tem boas cabeças, tem elementos que têm boa memória. Você deve pegar e conversar com eles.

Quais foram as repercussões das greves na vida dos trabalhadores?

Mudou muito. A greve serviu de parâmetro para muita coisa. O respeito, a maneira de tratar a chefia dentro das fábricas. $O$ trabalhador sindicalizado começou a ter muito mais respeito depois das greves. Foi uma coisa que serviu como uma lição. Os direitos começaram a aparecer. Você já não precisava requisitar tanta coisa. Proteção de máquina, proteção em uma portaria. A abordagem à gente. A revista passou a ser mais maneirada na entrada. Na entrada não. Mas na saída todo mundo era revistado. Começou a haver mais respeito. A greve serve, tem um significado bom. O resultado é sempre bom. Não parece, porque é um nome feio. Você para ali, quebra uma coisa aqui, faz sabotagem. Vai ter sabotagem, vai quebrar uma máquina, vai pôr uma bomba. Não tem nada disso. É balela. Não existe nada disso. A greve é duas coisas: você para por um pedido social, ou para por aumento de salário. Ninguém é inimigo do patrão. Essa história é outra coisa que não é verdade. Os jornais escrevem um monte de coisa. Mas o empregado gosta do patrão. O patrão gosta do empregado. Mas tem horas que o patrão precisa de algo, e você precisa de algo diferente. É essa a diferença. $O$ patrão precisa de uma produção melhor, precisa entregar tantos carros. E você precisa também manter sua família, tratar sua família de um modo melhor que antes. Aí começa o desacerto. Não combinam muito as idéias. Não combinam. O patrão precisa de algo, mas você também precisa de alguma coisa. E daí que nasce aquele atrito. Mas inimizade, não! Não existe. Eu ficar com ódio de você, e você de mim, não! Não existe. Quando termina a greve, parece que ninguém nem comenta. Nem comentário você vê. Cada qual vai fazer sua obrigação, e vai esperar o resultado. $O$ que foi acertado, o que foi conversado, o que foi decidido, tem que aparecer. Tem que aparecer. 
Você ainda encontra muitos dos companheiros dessa época, que participaram das greves...

Encontro. Eles vêm pagar mensalidade na minha salinha sala. Você entrou lá, né? Na minha salinha? Eu fico atendendo a moçada lá, que quer plano de saúde mais barato. Ele quer um médico, um urologista, um clínico geral. "Ô, Reinaldo. Pega aí a mulher do plano de saúde que eu estou precisando de um massagista, de um...” Aquele negócio da agulha, como é que chama?

Acupuntura.

Acupuntura. Telefono pra lá. "Seu nome. Sua ficha”. "Meu nome é tal". Ligo lá no plano de saúde: "Vê se marca uma consulta para esse elemento, que ele está precisando disso e daquilo”. Aí passo o dia. Mas como o acordo era para um só, e era muito, estava acarretando, mexendo com a mente, de tantas horas que ficava, então eles dividiram. Eu entro de manhã. À uma hora da tarde eu vou embora, descansar. Entra outro à uma hora. Cinco horas fecha o expediente e ele vai embora também. Somos em dois. É um cara que você deveria conversar com ele. Você deve conversar com o Roque, com o Geraldo. Eles são mais novos que eu. Mas eles lembram também de uma passagem boa. O Wilson, o negrão, o presidente. Também auxiliou muito nas greves. Ele também trabalhou nesse negócio que tem nas firmas agora, a comissão de fábrica. No meu tempo não tinha essa comissão. Agora tem. Eles são muito por dentro, conversam diretamente com o gerente, com os diretores da fábrica, com o pessoal da produção, com os mensalistas. Seria bom você conversar com eles também. É sempre bom.

Nos tempos da greve, os mensalistas se mancavam um pouco. Nós ficávamos em casa e eles iam trabalhar. "O que vier para vocês vem para nós também”. E eles não nos ajudavam a fazer greve. Mas quando vinha a porcentagem, eles queriam igual.

Mensalistas eram quem exatamente?

Mensalista era o pessoal do escritório. Nós éramos mais da graxa e do óleo. Era o pessoal da graxa e do óleo: "Vamos parar?" "Vamos". Mensalista não: "Ah, vou trabalhar. A porcentagem que vier para vocês vai ser dada para nós também”. E nascia um pouquinho desse desencontro. Mensalista. Pode gravar esse nome que é verdade. Eles eram mensalistas. Mensalista porquê? Você recebe por dia, por hora. Mas o mensalista não. Tem x por mês. A cada trinta dias o ordenado é x. Você tem tantos por hora. E lá também tinha uma coisa que eu esqueci de falar: hora extra. Depois do seu expediente, das suas oito horas de serviço, vinha um cara e falava: "Você precisa fazer mais duas horas! Você precisa fazer mais uma hora e meia! Estamos precisando de peças, precisando disso e daquilo. Você vai tomar um lanche aí, vamos dar um lanche para você e você vai ficar mais duas horas". Essas duas horas eram chamadas de horas extras. Nas fábricas tem muito disso.

O senhor fazia muita hora extra?

Fazia. Às vezes trabalhava sábado o dia todo, e o domingo também. Foi assim que eu construí minha casa. Com esse dinheiro extra eu construí uma casinha. Comprei uma casa velha, desmanchei e fiquei só com o terreno. Depois contratei um pedreiro e um ajudante. Primeiro pedi informação: se o cara sabe trabalhar, fazer acabamento. Me indicaram, fui lá, contratei o cara e fiz minha casa. Casa própria. Não pago aluguel. 
Essas horas extras ajudavam. É uma coisa que o Sindicato, e várias pessoas do Sindicato são contra. Mas às vezes dava algum resultado. O Sindicato é contra hora extra. Eles pedem para as pessoas não fazer hora extra. Mas não é de tudo ruim. A hora extra, na visão deles, quando alguém faz hora extra, caberia mais uma pessoa ou duas para trabalhar. Em vez de eu fazer dez, doze, ou quinze horas, poderia se pegar um cara na rua para trabalhar, para fazer mais oito. Nesse lado eles estão certos. A hora extra evita que a firma pegue mais um empregado. Eu concordo com eles. Mas ela não é um mal. A hora extra é um dinheiro que vem a mais no pagamento, e você pode contratar alguém lá fora para fazer algo em sua casa. E com aquele ordenadinho que a gente está acostumada a: recebeu, gastou, recebeu, gastou. Você não consegue fazer nada, fica paralisado. Mas com o extra tem um pouco a mais. Você pega o dinheiro extra, compra um pouco de material, paga o pedreiro, o encanador, o eletricista. Em uma construção precisa de um encanador, de um eletricista. Colocar as caixinhas, passar a fiação, puxar foi, puxar isso, puxar aquilo. No fim, colocar uns espelhos. A construção precisa de muita coisa. Além do pedreiro, você precisa de muitas pessoas. Uma pessoa para carregar o material, fazer a massa, fazer o reboque, fazer a massa fina, levar lá para o pedreiro executar. E seu ordenado são aqueles trinta dias. Não dão aquelas oito horas. Então você teria que fazer alguma coisa a mais para não ficar devendo. Você fica sujo. Chega sábado, o cara está esperando em sua casa, "O dinheiro acabou, não dá para pagar”. Não tem nada disso. Você contratou o cara, você deu a palavra. Nem que falte alguma coisa em casa, você tem que pagar. O que você acertou, tem que cumprir. Isso é lei de Deus. E as horas extras ajudavam. Meu sindicato é contra. Pedem para que a gente não faça as horas extras. Estamos tirando emprego de alguém que passa necessidade, de um pai de família que está gastando sua sola de sapato todo dia e não consegue emprego, porque um serviço que ele ia fazer, nós que estamos lá dentro estamos fazendo nas horas extras. $O$ Sindicato é totalmente contra.

O que o senhor achou de dar a entrevista? Como o senhor se sentiu?

Gostei, porque quando vocês aparecem aqui, é bom porque a gente volta a lembrar do nosso tempo de correria. Tomamos muita carreira dos soldados aqui. Vinha um, tudo bem. Vinham dois, tudo bem. Quando juntavam três ou quatro a polícia já chagava e "Ô, não pode! Nada de rodinhas aqui”. Se você insistisse, eles ameaçavam e você tinha que sair correndo. E eu já tinha esquecido tudo isso. Quando vocês aparecem por aqui, a gente volta a se lembrar. Era um tempo bom. A gente era bem mais novo. $O$ ano de 80 já está bem lá atrás. 70 então, nem se fala. Estamos hoje em 2007. Eé bom que a gente lembra de alguma coisa, passa a viver de

ilusão, de algumas coisas daquele tempo. É muito bom. E graças a vocês também. Vocês são um bem para nós. Lembrar de alguma coisa do passado é muito bom.

\subsection{Dimas}

Gostaria de saber algumas coisas de você. Onde você nasceu, se é casado, tem filhos, netos. 
Eu nasci na cidade de Timóteo, Minas Gerais. Vim para São Paulo em 72. Cheguei aqui no dia primeiro de setembro de 72, em São Paulo. Vai completar 36 anos, no dia primeiro de setembro. Eu casei faz 33 anos. Casei em 74, 30 de novembro de 74. Morei em São Bernardo, e continuo morando em São Bernardo. Tenho um filho de 25 anos que se formou no ano passado em educação física. É o Gabriel, meu único filho.

O que você faz hoje em dia?

Antes, você quer sabe as firmas onde trabalhei?

Claro, pode falar.

Eu comecei na Sesita, em Minas Gerais. Uma siderúrgica. Trabalhei nove anos e meio. Depois vim para São Paulo. Trabalhei na Lavos em Guarulhos. Fiquei dois meses e meio. Depois não deu certo, eu fui para a fundição Ebling, em Mauá. Fiquei dois meses e meio. Saí para entrar na Borg Warner. Na Borg Warner fiquei sete anos e sete meses. Depois da Borg eu fui para a Rolls Roice. Fiquei treze anos lá. Foi a firma pela qual me aposentei. Então trabalhei de 63 a 93. Trabalhei trinta anos e seis meses certinho. Eu me aposentei também por insalubridade, pela aposentadoria especial.

E hoje em dia você faz o quê?

Eu me aposentei pela Rolls Roice e sou diretor daqui da AMA desde 97. De 97 a 2007. Fez dez anos agora em novembro, e vai para onze anos. $O$ mandato nosso termina agora em novembro. Não sei se vamos pleitear um novo mandato ou não, como é que vai ser.

Dimas, sobre as greves das quais você participou, o que você lembra? O que você pode contar para mim?

Olha, eu participei de todas as greves, certo? Eu me lembro muito da Vila Euclides. Hoje é Estádio Primeiro de Maio. Não sei se é de sua época. Mas foi lá que eu participei de todas as greves. Vi muita repressão, inclusive da ditadura militar. Participei daquela cena onde os helicópteros passaram com os caras todos de metralhadora. E o Lula falando para todos ficarem calmos, para não sair do local. Ficar calmo, porque se tiver um tumulto, iria ser muito maior o acidente. Mas como todo mundo obedeceu direitinho, passaram, voltaram... Era o tipo de ameaça para inibir o pessoal. Assembléia na Vila Euclides era para mais de cem mil pessoas, na qual participavam Djalma Bom, Expedito Soares. Uma diretoria já passada. E não foi fácil. Depois não deixaram mais participar lá na Vila Euclides. Aí nós começamos a fazer nossas assembléias na Igreja Matriz de São Bernardo, nos fundos da paróquia. Houve vez em que o pessoal da polícia, através de investigação, entravam e iam prender as pessoas. Dentro da igreja. Houve até um conflito em que conseguiram descobrir quem era o investigador e colocaram o cara para fora. E depois que saía, também já tinha policial por fora. Houve aquele tumulto de jogar bomba de gás lacrimogêneo. E o pessoal enfrentou mesmo. E enfrentava mesmo. Não reprimia, não. O pessoal ia para cima mesmo.

$E$ as reivindicações nossas, acho que foi um avanço. Através desse movimento, dessas greves... Eu me lembro da questão da comissão de fábrica. Comitê sindical de empresa, comitê sindical de aposentados. Muitos diretores daquela época estão no governo, inclusive o presidente Lula. Então acho que tudo cresceu. Se não tivessem aquelas greves, em 79, 78... A primeira greve foi em 78 na Scania, você sabe, né? Depois em 79 e depois em 80. Depois teve 
em 81, mas aí foi mais devagar. Sofremos intervenção no Sindicato, em 79 e 80. Todos os diretores tiveram que sair. Aí entrou um interventor. E aqui, no Sindicato, ficou rodeado tropa de choque, polícia de todo jeito. Muitos que estavam aqui dentro tiveram que sair, não deixaram ninguém ficar. Mas o pessoal mesmo assim enfrentou. Até nesse dia eu vim aqui no Sindicato. Mas quando se viu a coisa, a polícia começava a jogar bomba. E aquilo dá uma queimação. Por isso que falam: bomba de efeito moral. Aquilo queima mesmo. Você tem que enfrentar uma cavalaria. Era um rebu danado!

Mas valeu a pena. Acho que nossa categoria metalúrgica, e vamos falar trabalhadores, evoluiu muito de 78 para cá. Agora com esse governo a gente tem mais diálogo, mais contato com eles para poder negociar. Antes nem abertura tinha. Hoje tem uma abertura. E agora, nesse momento, acho que a gente está passando por uma fase muito boa. É uma pena que é o último mandato do Lula. Gostaria que tivesse mais um mandato. Até para dar prosseguimento melhor das coisas. Vai entrar um outro que a gente não sabe quem vai ser. Talvez não siga a mesma linha. Muitos falam que não está indo bem. Mas eu acho, nós achamos que está indo bem. A opinião se diverge porque tem muita oposição, que sempre faz o jogo do contrário.

E o quais eram as reivindicações nas greves?

As reivindicações eram sobre campanha salarial. E também a carga horária, redução da jornada de trabalho. E também as causas sociais. As causas sociais também eram pauta das negociações. Porque o contrato coletivo dos metalúrgicos aqui favoreceu muita coisa. Favoreceu os que têm problemas de deficiência, favoreceu as mulheres, gestantes. Ampliou as causas sociais. Então foi criado o contrato coletivo na base aqui, especificamente dos metalúrgicos do ABC. E salarial. Foi uma coisa difícil, foi conquistado, mas não foi o que a gente queria na época. Então são essas as pautas.

Você lembra de seus companheiros na greve?

Nessa época eu não trabalhava na Rolls Roice. Eu estava na Borg, na qual eu era inspetor de qualidade. Sempre fui. Minha profissão sempre foi de inspetor. Então eu lidava com o pessoal da produção, com quem eu tinha amizade. Da inspeção também. E vinha para cá com eles. Agora falar nomes para você é difícil. Mas a gente trazia o pessoal para cá. Trazia para a Vila Euclides, trazia para a igreja, ia para as passeatas. Ia para a prefeitura, que tinha uma época que era na prefeitura. A gente trazia. A gente era bem mobilizado. Até mais que na Rolls Roice. Mas na Rolls Roice também ficou bom depois, ficou muito bom. Mas na época, naquele período, em 80, a Borg estava muito bem organizada. Então era fácil chamar o pessoal. O pessoal se mobilizava bem e vinha para cá. A gente vinha andando, participava de tudo. Tudo que você pensar a gente participava. Enfrentava também a "boca". Corria às vezes, ia para cima também. O negócio era pauleira. Era pauleira mesmo.

Eu acho que foi uma evolução. Acho que tudo, para melhorar, precisa de um sistema de evolução. Nada melhora só com diálogo, só com caneta. Você tem que criar um fato político. Se você não criar um fato político, não desenvolve nada. Então é isso que foi feito naquela época. Foram criados tantos fatos políticos que nós mobilizamos o Brasil todo. Então foi muito bom. 
O que você lembra da participação do Sindicato nas greves?

A participação do Sindicato, do qual o Lula era presidente... Tinha também o Djalma Bom, que era uma pessoa muito atuante. Tinha o Alemãozinho. Expedito Soares. Tinha o Rubão, que era o vice-presidente do Lula. Eu acho que a participação deles foi muito boa, porque eles conseguiram liderar todos os metalúrgicos, mobilizar todos os metalúrgicos, para poder participar. Eles não ficaram sozinhos. Então foi uma liderança muito perfeita, a melhor que teve até hoje, eu acho. Não desmerecendo quem está agora. Mas aquele momento era o momento da ditadura, um momento muito mais "fácil", que agora. Agora houve abertura, está mais democrático com o Lula. E na época estávamos na ditadura. Pode ter certeza que foi um dos movimentos que conseguiu acabar com a ditadura. Foi um negócio muito para frente. E graças ao Lula e à diretoria dele.

O que você lembra das assembléias e reuniões das quais você participava?

As assembléias... vamos pegar na Vila Euclides, que hoje é o Estádio Primeiro de Maio. Aconteceu também na Igreja da Matriz, aconteceu no Paço Municipal. Acontecia em vários lugares clandestinos também. Era o seguinte: a direção falava o que tinha que fazer, a pauta de reivindicações, como estava o movimento. Nós estávamos sendo reprimidos, como é que nós tínhamos que nos comportar, era um negócio que não poderia ser muito aberto. $E$ também dava a palavra para as pessoas falar. Não era só a diretoria que falava. Os metalúrgicos levavam, discutiam, aceitavam a opinião. Então foi um movimento histórico no qual participou a diretoria do Sindicato junto com os metalúrgicos. A diretoria não ficou sozinha. Tiveram respaldo da categoria. Isso em todos os sentidos. Estou falando da Vila Euclides, do Paço Municipal, da Igreja da Matriz. E estou falando de outros pontos também. Porque sempre tinha reuniões nas associações de amigos do bairro. Sempre tinha um lugar que fazia as reuniões em separado, porque era uma repressão muito grande.

O pessoal ficava muita atrás da gente, as Forças Armadas, inclusive a Tropa de Choque, Polícia Civil, a ROTA, investigadores. Isso que era pior, porque ficavam à paisana, todos no meio da gente, à paisana. Você não sabia se era ou não era. Pensava que era metalúrgico, e você estava se comunicando com a polícia. Esse que era perigoso. Esse é que dava mais problemas para a gente. Eles se infiltravam, no movimento e dentro das fábricas também. Punham o macacão, e você não sabia, no meio daquele monte de gente. Pensava que era metalúrgico também. E quando descobria o pessoal metia o pau mesmo. Dava o cacete e jogava para fora. Descobriam de vez em quando. Mas quando não descobriam, eles comunicavam à viatura. Mas tinha enfrentamento, também. Foi gente presa, muita gente. Só que os advogados do Sindicato iam lá e soltavam. Mas o que tinha de gente presa, não está escrito.

O pessoal naquela época enfrentava muito mais que agora. Mas também devido às condições daquela época. A gente sabe que hoje mudou, mudou completamente. Naquela época a gente sofria uma repressão que a gente tinha que desbloquear. Então foi um movimento muito bom.

\footnotetext{
${ }^{7}$ Provavelmente Dimas quis dizer "difícil”.
} 
Qual foi a primeira greve que você participou? Você lembra como começou a greve? Como foi participar de uma greve pela primeira vez?

A primeira vez foi por causa do restaurante da Borg. A comida não estava muito boa. Eu trabalhava só à noite lá. Então a comida estava muito ruim. Então nós, inspetores, junto com o pessoal da produção, mais os apontadores de produção, combinamos de fazer um boicote ao restaurante, à noite. O restaurante funcionava das nove às dez no jantar. E nós fizemos isso aí. Aí eu cheguei no supervisor de produção e falei: "Nós vamos fazer isso porque está ruim. O senhor almoça lá, o senhor percebe. O senhor janta lá, o senhor percebe". Ele: "Até acho que vocês devem fazer, mas eu não vou fazer. Nem eu nem os outros supervisores, senão fica mal para nós". "Então vocês aguardem, que nós vamos fazer". Paramos tudo! Ficamos uma semana. E depois dessa semana, eles trocaram o restaurante, por um muito bom. Aí todo mundo gostou.

Vocês pararam a produção?

Não, nós fizemos uma greve contra o restaurante. Só no horário da janta. A produção não tinha nada a ver, no caso. Aí o pessoal ia comer fora, na padaria. A gente se virava. Foi assim.

E de outras greves, que episódios são mais marcantes para você?

O episódio que mais marcou para mim foi na Vila Euclides, na greve de 80. Como eu te falei, foi quando eu vi aquele helicóptero passar, com o exército. Os caras de fora, dos dois lados, com metralhadora. Isso chocou demais, chocou pra caramba.

Sobre o trabalho na fábrica, o que você lembra? O que você fazia na fábrica?

$\mathrm{Na}$ Borg, fui inspetor de estamparia, fui inspetor de usinagem, fui inspetor de montagem. Depois desses três, eu vim para o dia. Eu trabalhava à noite. Vim para o dia, e vim para engenharia de produtos, e fiquei como inspetor de protótipos. Ali foi onde eu desenvolvi mais coisas. Foi na Borg. Fiz curso de desenho mecânico, fiz curso de dimensional. Ali aprendi muita coisa. Quando chegue na Rolls Roice, para mim era fichinha. Eu já tinha dominado tudo. Fiz muito curso, na minha profissão que sempre desempenhei.

E como era seu trabalho?

Na Borg, era embreagem. Platô e disco. Friç̧ão. Isso que eles faziam. Agora não é mais Borg, é Sachs. Eles produzem coisas da Lump, também. Então eu era inspetor disso aí. Só que tinha as peças, mola chata, bulbo. E fazia a montagem. Então eu tive uma experiência muito grande.

Quando eu fui para a Rolls Roice, já era diferente. Era motor de avião. Já tinha galvanoplastia, níquel penetrante, lavagem de peça inicial, tem solda, usinagem. Só que lá tinha que fazer o controle de um a um. Não pode fazer o controle por amostragem, pegar cem peças e olhar dez. Você tem que olhar as cem. É uma por uma. Porque depois que o motor é montado, vai para o banco de provas. Qualquer coisinha que acusar no banco de provar, tem que voltar para desmontar. A inspeção é cem por cento. Só que nessa firma que eu trabalhei, você trabalha à vontade, na Rolls Roice. Não ficam em cima de você. Show de bola para trabalhar. Restaurante de primeira, condução. Foi a firma de coração pela qual eu 
aposentei, que eu gosto. Não dizer que eu sou puxa-saco, nada disso. Tanto é que fizemos greve lá dentro de trinta dias. Tinha o presidente do Sindicato para reivindicar. E conseguimos aumento. Trinta dias direto. Fizemos passeata na Anchieta, vínhamos para cá no Sindicato. Foi pauleira. Ficava dentro da fábrica também, se reunia dentro da fábrica. Ficava para ver se tinha algum retorno da firma. Demorou trinta dias para sair a reivindicação, e conseguimos. E antes tínhamos feito uma greve de quinze dias. A firma não deu resposta, então ficamos mais trinta.

A experiência da gente é essa. A gente fala das greves da categoria, das greves gerais de 78, 79 e 80, mas a experiência da gente começa dentro da firma, dentro do chão de fábrica. Essa que é a experiência que a gente tem. É lá que a gente define, é lá que a gente faz. Quando você sai para fora, você sai junto, e já sai sabendo fazer. Já sai preparado.

O que você tem para falar sobre as condições de trabalho? Higiene, segurança.

Sobre as condições de trabalho, depende que firma. Tem firma que está bem mais preparada. No caso, por exemplo, da Rolls Roice. Eles dão o sapato de segurança, dão o capacete, protetor auricular, fechado dos dois lados. Dão protetor ocular. Visual e de ouvido. De concha, ou senão o outro. Têm um técnico de segurança. Têm todos os extintores preparados, certinho. Em cada sessão tem uma maca, caso aconteça alguma coisa com as pessoas. Uma vez caiu uma pessoa, pegamos a maca, levamos para a enfermaria. Desmaiou. Uma firma preparada.

Mas tem firma que não tem nada. São precárias na parte de segurança. Nas que eu trabalhei, a Rolls Roice é muito preparada. A Borg também era. Tinha todos os equipamentos, enfermaria, ambulância. Então estavam no mesmo nível. Agora, tem muitas firmas onde trabalhei, como a Fundição Ebling, em Mauá, que não tinha nada. Precária. A Lavos de Guarulhos, você não dá nada. Então acho que ainda tem muita coisa para ser melhorada nessa parte. A categoria tem que reivindicar essa parte também. Não só a parte salarial. É importante. Tem muito acidente, muito risco, falta muita coisa ainda. Agora, para falar a verdade, as grandes montadoras, eu sei que são preparadas também. Lá na Rolls Roice eu fui da CIPA, fui da Brigada de Incêndio, e fui fundador da Comissão de Fábrica. Por que eu estou falando isso, que sou fundador? Porque era para eu ser. O Miltão me chamou: "Vai você mesmo!". No final eu passei para um soldador. Porque depois eu aposentei. "Deixa ele porque eu aposentei, e ele tem muito tempo ainda para aposentar. Deixa ele trabalhar, porque já vou sair”. De fato, em janeiro eu me aposentei, e em novembro eu saí, em 93. Ele continuou, a comissão cresceu. Tinha um, agora tem três membros. Teve um avanço muito bom. É isso que eu falo: o principal é no chão da fábrica. Se cada fábrica fizer isso, resolve-se muito melhor coletivamente. Se cada fábrica tiver um movimento bom.

Nas Borg você foi de comissão também?

Na Borg, na verdade, eu não fui nada. Só trabalhei lá. Agora, na Rolls Roice eu fui três gestões da CIPA, uma gestão de suplente, na qual me mandaram embora no meu mandato ainda. Porque é assim: você tem um ano de mandato, e depois tem mais um ano de estabilidade. E me mandaram, mesmo como suplente. Aí quando eu saí, fui lá e reclamei; Falaram: "Você pode procurar seus direitos". E eu procurei no Sindicato. E ganhei o 
processo. E ganhei um processo de insalubridade também. Todos nós temos que reivindicar nossos direitos. Fiz tudo pelo Sindicato e ganhei.

E a comissão de fábrica se reunia bem. Apesar que a pessoa que foi primeiro foi muito fraca. Agora, não. Entrou o Rogerinho, mais a Tânia. Foi firmando. Fui confiando nessas pessoas. Até pensei: "Se soubesse que is ficar assim, tinha pego mais um mandato".

Como era na fábrica a relação com os supervisores e patrões?

Eu sempre fui mais do lado de nós mesmos, trabalhadores. Operadores de máquina, preparadores de máquina, apontadores de produção. Já o pessoal de escritório e da chefia, lógico que eu tinha que conversar. Tinha que conversar com encarregado, conversar com mestre. Mas procurava não misturar as coisas. Se tinha que conversar com um companheiro, coisas nossas, eu falava com eles. Eu não gosto de me envolver com chefe, nem para sim, nem para não. Só para tratar o que deve tratar. Só para fazer meu serviço. E quando tinha greve eu fazia também. A Rolls Roice até hoje não sabe. Mas nós viemos aqui no Sindicato, eu e um grupinho da CIPA, e conseguimos uma reivindicação de aumento. E depois na Rolls Roice veio no holerite, esse aumento. Aí todo mundo: "Como é que veio esse aumento aqui?" A gente sabe de onde veio. É o que eu falo, a gente tem que articular as coisas, tem que movimentar, porque nada cai do céu. Tem que ter união. A união faz a força, e se não tiver união não tem jeito. Aí criaram uma reivindicação boa para nós.

Você fez parte de movimento de bairro, ou ligado à igreja?

Fui vice-presidente da Sociedade dos Amigos do Jardim Silvina. Fiquei um mandato, de 76 a 78. Mas em 77 vim para cá e entrei aqui. Aí terminou o mandato lá, e fiquei só aqui. Mas mesmo assim, do que eles precisam, se tiver uma reunião, estamos todos juntos.

Movimento de igreja, quando precisa fazer uma passeata, alguma coisa assim, como primeiro de maio, estamos juntos também. Não que eu faça parte do movimento. Mas a gente está sempre aderindo.

E tinha alguma articulação com o movimento de bairro nas greves?

Tinha, porque o Lula, o Djalma, falavam muito para a gente nos bairros, nos botecos, em casa, comunicar os amigos. Conscientizar as pessoas do movimento que a gente estava fazendo. "Não saia daqui, e cuidado para não ser investigado por alguém, porque pode acontecer alguma coisa. Se quiserem, vão pescar, mas sempre tenha cuidado. Não se precipite em nada. Mas a mobilização é importante. Não só aqui, mas levando para o bairro, para a igreja, para a sociedade de amigos. Leve para qualquer lugar. Mas não deixe de fazer". Isso acho que foi muito positivo, porque aumentou muito o movimento. Foi um movimento muito grande. E eu fazia minha parte nisso aí. Não só eu, como outros. Levava o pessoal para a assembléia. Para a Vila Euclides, ou para o Paço Municipal. Na Vila Euclides proibiram. Aí depois fomos para o Paço. Ao proibiram o Paço. Aí depois o padre conseguiu para nós a Igreja da Matriz.

Você fazia parte de algum grupo político, ou de algum partido?

Meu partido é o PT, o Partido dos Trabalhadores. 
Mas você participou na época da fundação?

Mas na época que foi fundado não participei. Em 82 o Lula foi candidato a governador, $e$ perdeu feio. O Zé Ferreira ganhou como vereador aqui, e está até hoje como vereador do PT. $O$ Gilson Menezes ganhou como prefeito, o primeiro prefeito do PT, em Diadema. O que estou querendo dizer é o seguinte: sempre votei no PT. Porém não participei da fundação. Eu e minha família sempre votamos no PT. E vários outros amigos meus. Eu fui me filiar em 96, faz 12 anos.

No seu ponto de vista, quais foram as repercussões das greves na vida do trabalhador? O que mudou?

Eu acho o seguinte: depois das greves, o trabalhador ficou mais firme no chão da fábrica. Por tudo que nós passamos, quando voltamos para o chão da fábrica, voltamos com mais confiança. Tanto é que criamos as comissões de fábrica, o comitê sindical de empresa. Acho que foi um estímulo para melhora. Enquanto não tiver um movimento mais revolucionário, as coisas não melhoram não. Acho que esses movimentos de 78, 79 e 80, indiretamente foram revolucionários. Greve. Mas tem que criar um fato político. Quando o pessoal voltou para o chão da fábrica, voltou mais confiante. O pessoal ganha mais confiança. Confia mais em si e no conjunto dos trabalhadores.

Você ainda encontra os companheiros que participaram com você nas greves?

Encontro, da Borg, da Rolls Roice. Na Rolls Roice não pegamos a greve de 80, pegamos a greve de lá. Em 79 e 80, eu estava a Borg. Inclusive viemos até pegar cesta básica. Não tinha dinheiro mais, que a firma não estava pagando. Começaram a doar cestas básicas. Eu cheguei a pegar uma cesta básica, na época. Faltaram as coisas para mim também. Faltou para muita gente, porque a firma bloqueou o salário. Não só da Borg, de várias firmas. Foi uma greve de 41 dias. Então nós vínhamos pegar a cesta básica, entravamos na fila na Igreja da Matriz. Acho que foi uma passagem muito boa, porque teve uma evolução. Criou-se uma outra cara para os movimentos. $O$ movimento se estendeu mais, criamos os contratos coletivos. Acho que essa greve ajudou em muita coisa para os trabalhadores. Inclusive para derrubar a ditadura que estava aí.

Tem mais alguma coisa que você gostaria de falar sobre as greves?

O que eu queria falar é o seguinte: agora não está mais havendo muitas greves. Por que não está havendo mais greves agora? Porque esse governo tem mais diálogo. Negociação. $O$ ministro da previdência é nosso, que foi ministro do trabalho, que é o Luiz Marinho. Temos o presidente. E temos vários canais de comunicação agora. A rádio comunitária do trabalhador está saindo agora, em Mogi. Que é muito importante. E outras rádios comunitárias por aqui estão pedindo concessão.

Das greves de 78, 79 e 80, eu só tenho a acrescentar o seguinte: Houve muita covardia por parte do governador do estado, que na época era o Paulo Maluf. E ao mesmo tempo temos que agradecer o prefeito daqui, que cedeu o Paço Municipal. Que é o Tito Costa. E auxiliou a gente em tudo. E tem que agradecer os padres, que deram uma força danada, cedendo a Igreja da Matriz, inclusive para fazer reuniões, entrega de cesta básica para os trabalhadores que estavam precisando. É isso aí. 
O que você achou de dar essa entrevista, de lembrar das coisas? Como você se sentiu?

Olha, sinceramente, eu não gosto de dar entrevista. Mas no desenrolar da coisa eu gostei muito. Achei muito bom, bom mesmo. É que não sou muito bom de oratória. Mas você deve entrevistar outros. $O$ Wilson, o Geraldo. Você vai ver que tem coisa diferente no meio. Nós estávamos todos juntos, mas eles vão acrescentar mais coisas. Tem coisa que eu falei que eles não vão falar.

\subsection{Wilson}

Wilson, onde você nasceu?

Eu nasci em Bebedouro, uma cidade do estado de São Paulo, próxima a Barretos e Ribeirão Preto.

Você é casado? Tem filhos e netos?

Sou casado, tenho quatro filhos e cinco netos.

Em quais fábricas você trabalhou?

Eu comecei trabalhando na roça. Fui trabalhador rural desde criança até os 21 anos. Depois eu fui para Jundiaí, onde eu fui trabalhar em indústria. Primeiro eu trabalhei em uma empresa de terceirização de pinturas. Pinturas de máquinas e paredes. Houve um fracasso, $e$ meu patrão, como gostava muito do meu trabalho, arrumou para eu trabalhar na Crupi em Jundiaí. Aí eu trabalhei durante um ano na Crupi. Depois eu trabalhei um ano no frigorífico Guapeva. Hoje ele fechou, não existe mais esse frigorífico. Aí em 73 eu arrumei na Forjaria São Bernardo, aqui em São Bernardo, através de um tio de minha esposa que já trabalhava aqui. E passei para a área metalúrgica do ABC Paulista. Aí trabalhei catorze anos na Forjaria São Bernardo. Fui mandado por greve. Fui mandado sem justa causa, por greve. E dois meses depois eu entrei na Mercedes-Benz, aonde eu trabalhei nove anos e acabei me aposentando.

Hoje em dia você faz o quê?

Hoje eu sou presidente da Associação dos Metalúrgicos Aposentados do ABC. Até outubro eu fui presidente do Sindicato Nacional dos Aposentados e Pensionistas. E hoje eu sou presidente do Patronato INCA CGIL. É uma instituição da Itália, que tem aqui no Brasil. $O$ patronato quer dizer assistência na Itália. Aqui no Brasil dá a tendência para "patrão". Então eles colocaram o Instituto: Instituto Nationale de Assistência Previdenciária. É o INCA, que eles chamam. E eu sou presidente do INCA há dois anos, o presidente nacional.

E venho também trabalhando, porque dentro dessas instituições eu não tenho um salário. Então o que eu tenho é assim: se eu viajo para a Itália, para algum país fora, o INCA me banca a passagem, a hospedagem e a alimentação. E quando eu estou fora, quando eu 
viajo para alguma coisa aqui no Brasil, quando o INCA não paga, o Sindicato pagava, e a AMA também tem pago as passagens para mim. Para discutir a questão da aposentadoria com o governo federal, a gente tem feito esse trabalho. E a questão da AMA é estar discutindo e debatendo com os aposentados nossa questão salarial. Porque eles chamam de benefício. Não é um benefício. É um salário que nós depositamos durante um longo tempo de nossa jornada de trabalho no INSS, e depois quando a gente aposenta, a gente ressarce pouco a pouco esses valores. E tem uma briga. Porque? Porque nós sempre contribuímos com o teto da previdência. E o teto da previdência atinge uma média de dez salários. E quando nós aposentamos, nós aposentamos com uma média daquele teto da previdência, $e$ não com o salário que a gente tem na fábrica. Então já cai quarenta por cento do valor do nosso salário. E ano a ano o governo vem dando a inflação e valorizando o salário mínimo, dando um aumento real ao salário mínimo. E nós vamos ficando para trás. A gente vai perdendo nosso poder de compra. A mercadoria, a cesta básica, sobe de acordo com o salário mínimo, e não com o nosso valor, dos aposentados. Só que nós não temos um lugar, um local, um supermercado onde nós, aposentados, pagamos mais barato. Não temos desconto na conta de luz, na água. Não temos desconto no IPTU. Então pagamos todos nosso impostos como se estivéssemos na ativa. E o governo não passa esse valor que está depositado para a gente. Essa caixinha que nós formamos, ele não passa esse valor corrigido para nós. Então é essa a diferença que a gente tem. A previdência arrecada muito dinheiro. Mas na hora de distribuir, ela distribui, para nós que somos categoria mais fragilizada... Não temos como tirar mais do governo, porque não é uma categoria unida. É uma categoria praticamente desfacelada. E cada um que forma uma entidade, procura olhar para sua entidade e não para um contexto geral. Porque nós precisamos discutir com as entidades a questão de sua diretoria estar se unificando para a gente poder trabalhar na questão de pressionar o governo, a previdência, para ter uma melhora do nosso salário. Porque quando o governo deu dois por cento de aumento real para nós, conseguiram aumentar o valor do PIB, porque o aposentado foi à compra. Não que ele foi esbanjar, ele foi comprar o que ele precisava. Então você vê que a necessidade do aposentado é muito grande.

E a gente trabalha. Eu tenho trabalhado. Com os processos que eu ganhei, eu tive um acordo com a Mercedes quando eu saí, porque eu estava dentro da estabilidade. Eu ganhei um processo de insalubridade. E ganhei um processo da URV. Então, dentro disso, eu comprei uma van, e com essa van eu faço carreto, aos finais de semana. Então levo o pessoal para a praia, casamento, aniversário. Levo para o Playcenter. Então de sexta, sábado e domingo, depois do expediente da AMA eu vou fazer esse carreto. E antes de eu entrar aqui eu vendia produto de limpeza. E continuo vendendo produto de limpeza.

Wilson, voltando lá para 78, 79, 80, o que você lembra dessas greves? Que episódios são mais marcantes para você?

Olha, eu tenho uma grande admiração pelos metalúrgicos do ABC. E faço parte dessa história. Porque era uma época de ditadura militar, onde se você estivesse com duas ou três pessoas conversando na esquina, a polícia chegava e reprimia. Então na minha juventude... em 64 eu tinha catorze anos. E para 84, são vinte anos de ditadura militar. Então eu fiquei engrandecido em ver a coragem dos metalúrgicos em, naquela época, ir para a rua e pedir a mudança. Porque eles não agüentavam mais aquele regime. E também a inflação naquela 
época era enganosa, porque os militares diziam um valor para a inflação, e era outro totalmente diferente. Era o dobro ou o triplo daquilo. E a gente via no nosso salário a defasagem. E a gente não podia falar nada. E os metalúrgicos, com essa garra e essa coragem, entram de cabeça e conseguem a começar a mudar nos anos 78 e 79. Não que antes não tivesse luta. Teve luta. Mas eles conseguiram, nesses anos mais fortes, começar a transformar o país. E a solidariedade das pessoas que eram oprimidas, começou a ajudar nessa questão. Então a gente diz que naquela época o povo queira mudar.

E era uma coisa engraçada. Naquela época o sindicato dos Metalúrgicos tinha 24 diretores. E representava São Bernardo e Diadema. Eram essas duas cidades, não era o ABC todo. E não tinha comissão de fábrica, não tinha na época uma CIPA combativa. Os próprios trabalhadores, ao ouvirem o som da luta, entraram de cabeça nisso e fizeram o acontecimento. Então a gente ter vivido esse tempo, essa época, foi uma coisa muito gratificante, de ver essa coragem. Naturalmente, houve pessoas que se aproveitaram da ocasião. Houve pessoas que foram mandadas embora. Pessoas que não arrumaram mais emprego, porque a carteira foi marcada. Tiveram que arrumar outros meios para tirar carteira nova, para arrumar outros empregos, começar tudo de novo. Aquela experiência que tinha, devido a carteira estar marcada, se ele era ferramenteiro, se era mecânico, se era da manutenção, ele teria que começar outra profissão. Foram muitas famílias que se separaram na época. Porque perdia o emprego, o cara tinha um certo ganho. De repente a mulher não aceita, porque não está com aquela mente como a pessoa estava. Então isso aconteceu muito. A gente via muitos companheiros. Não cheguei a ver pessoas sendo mortas, mas vi muitas pessoas sendo baleadas no movimento, pela polícia. A policia vinha, reprimia. E aqui em São Bernardo mesmo chegou a ter até tanque de guerra. Eles traziam tanque de guerra e deixavam aqui. Aqui nessa Praça Brasil, aqui em baixo, ficaram três tanques de guerra. Eles chamavam São Bernardo de "a nova república", achavam que iríamos fazer a revolução. E fizemos a revolução. Não armada. Mas fizemos a revolução ideológica.

E eu sou um dos fundadores do fundo de greve. Lá na [Igreja da] Matriz a gente separava mercadoria para o pessoal. E até hoje eu sou sócio do fundo de greve. Então isso para a gente é uma coisa que não tem o que pague. Porque a gente faz parte dessa história. E eu lembro de uma frase do Lula na porta da Forjaria São Bernardo. Eles, do Sindicato, tinham uma Veraneio. E essa Veraneio era uma ambulância. E aí eles acabaram com a ambulância e a transformaram em um carro de som. E tinha um gerador. E antes disso tinha um megafone, começavam a falar com o megafone. Uma hora o Lula falou "Não quero isso aqui! Vou falar...”, e tirou o megafone e começou a falar sem ele, na porta de fábrica. E aí veio depois a Cacilda. Tinha aquela cornetona, tinha o auto-falante, e colocavam aquelas cornetonas, e o gerador. O gerador fazia mais barulho que a voz que saía do auto-falante [risos]. E aí a grande revolução mesmo foi quando veio o Barão de Tefé, que era um ônibus. O Sindicato comprou um micro-ônibus, e aí instalou um som extraordinário. Todo mundo quando ouvia aquele barulho na fábrica já sabia... quando tinha uma assembléia em uma fábrica, o pessoal na outra estava ouvindo. O som era muito bom. Barão de Tefé era o nome que deram para o ônibus, e Cacilda era a Veraneio. E aí veio o Barão de Tefé e todo mundo queria fazer seu discurso no Barão de Tefé. Era bonito o ônibus, era uma novidade naquela época. 
Sobre as reivindicações, você lembra quais eram as reivindicação de vocês nas greves?

Tinha uma coisa que era a seguinte, que o Sindicato fazia assim: a inflação estava em, vamos supor, vinte por cento. Então nós pedíamos oitenta. Vinte por cento de inflação e sessenta por cento de aumento real. Então esse era o lema, para a gente chegar pelo menos nos quinze. Aí tinha as negociações, ficava aquele debate.

E o que acontece? Inflamavam o pessoal. O pessoal já começou a fazer contas. $O$ metalúrgico começou a aprender a fazer cálculo. Então você via no pé da máquina, na hora do almoço, o cara fazendo conta de quanto iria ser o salário dele. E aquilo movimentava. Era um chamariz que a diretoria do Sindicato fez. E uma coisa, que não lembro se foi no ano de 80. A última grande greve mesmo foi em 80. Não sei se foi 79 ou 80. Saíram, ninguém sabe quem fez isso. A categoria estava um pouco oscilante. Então estava oscilando, vai para a greve, não vai, aquela coisa. E aí de madrugada soltaram um panfleto nas portas das fábricas, dizendo assim: "Еu amo meu patrão". [risos] Aí o pessoal pegava aquela papel, olhava assim, e jogava fora. Amassava e ficava revoltado. Aquilo deu impulso na greve porque ninguém queria amar o patrão, todo mundo ficou revoltado [risos]. Aí surgiu a greve. Em não estou lembrando se foi em 79 ou se foi em 80. Mas foi um fato que a gente lembra até hoje. Aquele comentário dentro da fábrica. E aí perguntavam: "Você ama seu patrão, né?". [risos] Muito boa essa aí.

Teve um fato também na Volkswagen. Eu trabalhava na Forjaria. Aí nós estávamos em uma reunião na Volkswagen, e a Volkswagen estava com problemas. Não queriam fazer um acordo, a Volkswagen estava segurando muito. Aí todo falando: "O que a gente faz? $O$ que a gente não faz?”. E a Volkswagen estava num patamar de mandar muita gente embora. Aí, a assembléia estava quase finalizando, um rapazinho chega e fala assim: "E se a gente for a um supermercado e pegar aqueles sacos de supermercado e fazer uns furos nos olhos $e$ no nariz? Ninguém vai conhecer quem é quem. A gente entra na fábrica, vai ao banheiro, coloca e sai fazendo um arrastão". Aí o pessoal foi. Pegaram a Tereza, que era um corda toda lambrecada de... Aí o pessoal saiu com aquela corda e ninguém sabia quem era porque estavam com aqueles sacos [risos]. E aí a Tereza começou a rodear todas as outras fábricas. Então quando tinha greve e o pessoal não queria parar, usavam a Tereza.

Quem eram seus companheiros de greve? De quem você lembra?

Na Forjaria São Bernardo, eram o Zezão, José Lopes, o Roberto. O Roberto a gente chamava de Robertão. Ele tem um nome suíço, o sobrenome dele é suíço. Um nome complicado, não lembro agora. O Nelo e eu. E nós tínhamos um grupo de fábrica formado por pessoas de vários setores que formavam o grupo de fábrica. Tinha o José Damião, tinha o Jacaré, tinha o Soldado. Mais apelido, a gente conhecia mais por apelido.

E essas pessoas eram as pessoas que a gente reunia, vinham para o Sindicato, discutíamos e debatíamos com eles e eles eram os formadores de opinião. Então a gente tinha toda essa questão. E lógico que nossa questão mesmo era o banheiro. Nossas reuniões, nossas assembléias dentro da fábrica eram no banheiro. Então a gente ia para o banheiro, $e$ tinha um grupo lá. A gente debatia, voltava dentro do prazo na hora do almoço. Então a gente sentava e discutia. Até que a gente conquistou na fábrica o direito de fazer uma vez por mês uma assembléia com o pessoal. Então a gente teve essa conquista. A gente sentava. Era uma hora por mês, a gente parava toda a fábrica e ia fazer reunião com o pessoal. O horista 
ia, mas mensalistas eram poucos que iam. Porque o mensalista se sentia bem informado, porque liam jornais, eles tinham tempo para ler os jornais. A empresa sempre pediu para os mensalistas estarem lendo os jornais, as notícias, até para ter um desembaraço na leitura e nas negociações.

E muitas vezes algum guarda acabava acompanhando a gente e ficava do nosso lado, e não do lado da empresa. Então aquele segurança, aquele cara que vigiava a gente, passava mais para o nosso lado que da empresa. Então isso era uma conquista.

E a gente vê que hoje a empresa se adaptou. Poucas hoje não fizeram isso. Mas a maioria das empresas respeitou essa organização. E hoje os comitês sindicais e as comissões de fábricas, antes de fazer qualquer pressão, ou qualquer greve, elas formulam propostas, levam para a empresa, sentam e discutem. Na época, não. Na nossa época de militante sindical a empresa não aceitava discutir. Por isso que tinha muita greve. A gente levava uma pauta e muitas vezes eles nem aceitavam a pauta. Teve caso de diretor da empresa rasgar a pauta na frente do dirigente sindical. Hoje a mudança foi muito grande. Mas não ficou fácil! Ficou mais difícil. Porque a pessoa, o próprio sindicalista hoje tem que estudar. Ele tem que ter uma formação. Para ele elaborar um documento, para ele elaborar algumas coisas, para ele ter propostas, ele tem que fazer por escrito e entregar para a empresa. Então não é que ficou fácil. O pessoal fala: "Ora, hoje não tem mais greve”. A empresa também foi se adaptando às coisas. Viram que o próprio trabalhador tem razão no que ele reclama. Agora, entra em debate, discute. Algumas empresas ainda fazem greve, porque o patrão ficou lá atrás, ainda está muito atrasado. Mas a discussão, o debate, isso faz parte da categoria. E sindicato é lei. Agora, muitos por aí não têm esse entendimento, que tem que existir o sindicato. Hoje o sindicalismo é um sindicalismo moderno.

O que você lembra sobre a repressão policial e política na época das greves?

A repressão policial foi muito dura para a gente. Era a época que a ROTA estava no auge. A ROTA, a tropa de choque. Era um momento muito dificil para a gente. Depois das dez horas, se você estava sozinho na rua, os caras vinham, reprimiam, batiam. E a tropa de choque, quando vinha, não queria saber se era trabalhador, se não era trabalhador, ou se estava indo ao banco. Eles vinham com o cacetete e todo mundo tinha que correr. Era uma repressão muito dura. E na época também era o governo Maluf, que dizia que bandido tinha que ir para a cadeia, que nós éramos vagabundos, que não queríamos trabalhar, que tínhamos serviço. $O$ Maluf foi na época um governador muito repressor. E mandava a polícia pra cima. E na época havia muitos policiais à paisana, que se infiltravam nas greves para ver o que estava acontecendo. Muitas vezes no Sindicato a gente tinha que apresentar carteirinha para entrar. Naquela época também tinha muitos guardas de empresas grandes que eram olheiros, para entregar o pessoal dentro da fábrica. Ele se sentia um dono da fábrica.

E depois os policiais começaram a ver realmente que a gente tinha razão naquilo que a gente fazia, que era pedir aumento. Porque fomos uma categoria que conseguiu segurar por muitos anos um salário que era um salário de referência no país. As outras categorias, como os bancários, que não entraram em greve na época, ou os professores, os químicos, tiveram um achatamento nos seus salários. A gente chegava no caixa do banco, e os caras engravatados, porque tinham um salário razoável. Aí a gente via o negócio cair, o pessoal começando a levar marmita. O cara trabalhava no banco e tinha que levar marmita. E na 
época a gente era criticado, porque entrava no banco, a pessoa se colocava como bancário, $e$ dizia que estávamos chorando de barriga cheia. E a gente vê hoje a grande defasagem dos bancos, a diferença salarial. Porque os bancários tinham um salário razoável. Eram praticamente classe média. A gente passava nas lojas e os lojistas, os operadores, os vendedores, todo engravatados, principalmente Pernambucanas, Riachuelo, estavam todos de camisa branca, com gravata, e de repente o salário começa a achatar. Começa a ter uma diferença salarial. E a gente era criticado por essas pessoas. Então tinha repressão tanto por parte dos policiais como por parte de operários contra a gente. E quando cai o salário deles e a gente passa a ter um salário de referência num nível nacional - não que estivéssemos ganhando bem, eles é que estavam ganhando mal - eles começaram a se mobilizar, começaram a lutar. Mas não conseguiram recuperar o valor de seus salários como os metalúrgicos. Eles ficaram sempre para baixo.

Então começa a ter também dispensas, e vem a questão da terceirização. O banco começa a terceirizar, algumas indústrias começam a terceirizar. E isso começa também a achatar o salário do pessoal. E hoje a terceirização é uma grande inimiga do trabalhador. Se antes ele ganhava seis mil reais, ele passa a ganhar mil e quinhentos, ou seiscentos, setecentos reais. Então isso é um achatamento na questão do trabalhador.

Mas acho que a repressão policial, nos anos setenta e oitenta foi muito grande, muito perversa. Também por orientação da ditadura militar. Eram anos de ditadura militar, e você não podia expressar nada. Eles davam a ordem e você tinha que obedecer. Os metalúrgicos foram desobedientes, por isso muito apanharam. Eu corri bastante. Nunca cheguei a levar cacetada da polícia, mas corri bastante. Corri e muitas vezes entrava dentro de um lugar, ficava quieto, como se estivesse olhando vitrine. Os caras passavam, e depois, tranqüilo. Mas era uma repressão muito difícil.

Como eram as assembléias e reuniões que você participava?

As primeiras assembléias que eu vim a participar foram no Sindicato. E pelo que eu sei da diretoria do Sindicato, eles tinham que mandar a pauta da reunião para o DOPS, qual seria o discurso, e vinha a polícia acompanhar a assembléia. E muitas vezes pessoas que se alteravam, falavam mal do governo, já saíam presas de dentro do Sindicato. Ou eles saíam lá fora, já estavam marcados, e o camburão já estava esperando para prendê-lo. E a maioria do pessoal então pedia para a pessoa ser branda.

E tinha também as reuniões secretas. Muitas reuniões secretas para ver qual era o perfil, como a gente ia se portar, como a gente ia se defender.

Depois foi para a Vila Euclides. Na época o prefeito aqui era o Tito Costa. Aí começaram a trabalhar na Vila Euclides. Na Vila Euclides foi proibido. Cortaram a luz, cortaram o som, cortaram tudo, o helicóptero voando por cima. Depois foi para a Praça no Paço Municipal. No Paço Municipal a polícia cercou também. E depois viemos aqui para a Igreja da Matriz. Aí na Matriz houve bombas dentro da igreja, pessoas machucadas, ensangüentadas. Mas o pessoal foi resistente. Como eu disse no início: eram 24 diretores no Sindicato. Mas tinha uma grande massa que queria mudança, e isso ajudou muito.

E uma coisa que a gente admira no companheiro Lula e na sua diretoria é que não foram omissos em nenhum momento. Eles assumiram a greve. Como liderança eles deram o exemplo de unidade, de vir na frente e trabalhar, assumindo totalmente a greve. $O$ apoio, 
vinham e conversavam com a gente, davam orientação, como a gente poderia se comportar. Nos estávamos de greve, então não era para destruir isso, destruir aquilo, jogar pedra. Alguns no meio a gente sabia que eram policiais infiltrados, e eles jogavam pedras nas vitrines das lojas. E aí a polícia vinha para dispersar tudo. Então teve passeata de mulheres. As mulheres vinham fazendo panelaço. Então as assembléias, as greves, as passeatas, tiveram uma influência muito grande na sociedade. E aí a gente começou também a montar os blocos. De um lado e de outro você vai ficar tomando conta, porque havia muita garrafa de pinga. Muitas vezes o cara terminava de tomar a garrafa de pinga e queria jogar a garrafa. Então já tinha um pessoal para segurar e ele não jogava. Porque o dono da loja, o pessoal que estava ali não tinha nada a ver com a greve. Era uma greve contra a empresa onde a gente trabalhava. E não contra o lojista, ou contra quem quer que seja. Então isso a gente conseguia controlar. E com o tempo a polícia começou a ser mais branda com a gente porque começou a entender nosso lado.

Mas a assembléia era sempre assim: com o Sindicato aqui eu aprendi muito a dar a palavra às pessoas, e não determinar quem ia falar. E o Lula sempre falou uma coisa que era a seguinte: você tem que conversar com aquela pessoa que é contra você. Porque ele que tem a crítica vai mostrar seu defeito. Quem te elogia não vai falar seus defeitos, vai sempre te elogiar. Mas aquele que faz a crítica sua é com quem você tem que conversar, porque você vai melhorar dentro da crítica que ele fala. Era uma coisa que a gente via ele falar muito.

Na realidade o Sindicato dos Metalúrgicos foi, é e continuará sendo uma escola para a gente. Eu acredito nisso porque muda a direção, mudam os diretores e a gente vê que ele mantém um padrão de articulação, como exemplo para os outros, sem medo de... errar todo mundo erra, né? Mas eles têm essa força e a coragem de estar mudando todo o conceito da história do sindicalismo no Brasil.

Você lembra qual foi a primeira greve da qual você participou? Como foi entrar em greve pela primeira vez?

A primeira greve que nós entramos foi em 79, não foi em 78. Em 78 só parou a Scannia, ficaram três dias. Em 79 nós ficamos 16 dias parados. Eu morava próxima a Piraporinha e vinha a pé para a Forjaria. E para mim era uma experiência, porque eu nunca tinha visto uma greve, pois eu tinha vindo do interior. Aí eu vi todo mundo andando para a firma, porque a greve foi decretada de madrugada, e eu entrava das duas às dez. Eu vim e estava tudo parado. Ali na Avenida Pirapirinha não era duplicado, era mão dupla com uma faixa no centro. E parecia festa. Então eu vim para a firma, e vinha até para trabalhar. Então quando eu cheguei perto da firma o pessoal, os colegas, falaram: "Olha, está tudo parado hoje”. Eu falei: "Nem vou chegar lá". Então fiquei ali na esquina com o pessoal. Depois nos chamaram para o Sindicato, viemos aqui para o Sindicato e foi feita uma assembléia. Já haviam decretado a greve de manhã cedo. Então ficamos 16 dias parados em 79. Foi a primeira greve que eu participei.

E depois veio a greve de 80 , que foi a segunda. O pessoal já estava vacinado. Então em 80 foram 42 dias parados. E a gente ali sem voltar para a firma. Alguns voltaram, furaram a greve. Era aquele negócio de "fura-greve". Eram os "furões" de greve. E foi uma coisa interessante que em 81 foi um fracasso. De 81 a 83 as greves foram um fracasso. E justamente os caras que furaram a greve foram mandados embora. [risos] A maioria. 
Inclusive tinha reclamação: "Poxa, eu vim trabalhar e agora você me manda embora!". Mas o que chefia entendia e depois falava para a gente? Falavam: "Poxa, se esse cara é furagreve, eu não posso confiar nele". [risos] Então a própria chefia falava que não podia confiar no fura-greve porque ele está contra os outros, é um traidor da categoria. Então ele era mandado embora. Havia outros que tinham problemas, o cara faltava e furava a greve para tentar apaziguar as coisas. Mas como eles diziam era um mau funcionário. Tinham problemas que eles não aceitavam. Então quando chegava o momento eles mandavam aquele pessoal embora. E houve pessoas que falavam: "Fui mandado embora por causa do Lula". A gente vê isso até hoje. Até outro dia tinha uma senhora falando: "Meu irmão foi mandado embora da fábrica porque ele foi acompanhar o Lula, e ficou um tempão, passou até fome". Aí eu falei para ela: "Mas eu não ouvi falar que o Lula teve fábrica". Aí ela falou: "Não, foi por causa da greve", "Não, a greve é outra coisa. Se ele foi mandado embora não foi por causa do Lula. Na empresa onde ele trabalhava, o pessoal votou pela greve. Então fizeram a greve. Mas não foi por causa do Lula. O pessoal vota. Se o Lula fosse pedir para cada um que faz greve ficar em casa, seria outra questão. Mas, não. Houve uma votação na porta das empresas". Aí ela falou: "Mas eu sei que ele não arrumou mais emprego". Eu falei: "É, deve ser porque ele tem algum problema. Porque a maioria do pessoal que foi mandado embora na greve arrumou emprego. Começou lá de baixo, novamente, fez alguma coisa e conseguiu arrumar emprego". Depois falou: "Vou conversar com ele". Mas ainda até hoje tem gente que fala isso. Mas era porque o pessoal era ruim mesmo de serviço, era ruim de trampo. Faltava, tinham muitos atestados. Quem trabalhava mesmo ficou. A não ser que brigava. Agora, quem era mandado por justa causa eram os dirigentes sindicais. Muitas vezes eram afastados. Entravam com processo e retornavam. Teve caso na Ford, teve caso na Volks, na Mercedes-Benz. Casos de diretor que em retornou. Preferiram pagá-lo estando fora a deixar que retornasse para a fábrica. Então teve muitos casos. Mas a peãozada, não. Mas tinha também aquelas fábricas que diziam que havia excedente. Então aproveitavam a ocasião e mandavam. [risos] Geralmente era isso.

Mas alguma coisa que você se lembra de alguma greve?

A gente fez greve não só nessa época. Na Forjaria São Bernardo a gente fez greve por terem mandado pessoas embora, pessoas doentes. Nós fizemos greve porque, como era forjamento, uma área perigosa, de risco, havia pessoas que perdiam a mão, perdiam parte do braço. Então a firma, na época, não tinha o... como se fala? Não é o contrato coletivo de trabalho. Me fugiu o nome agora. As cláusulas sociais. Então o Sindicato pouco discutia as cláusulas sociais. Depois esse pessoal passou a fazer acordo para ter estabilidade, os que se acidentavam dentro da empresa. Então a empresa tinha que ficar com ele e colocá-lo em uma área que se adaptasse à seqüela que a pessoa tivesse. Porque a pessoa se acidentava e a empresa mandava embora. Então o Sindicato começa a fazer o acordo nessas questões sociais e começa a garantir o trabalhador dentro da empresa até se aposentar. Então foi uma das coisas muito positivas que a gente teve. E aí, mesmo assim o pessoal desrespeitava essa cláusula, e acabava mandando embora. Então a gente parava para garantir o valor disso. Aí, com essa questão das cláusulas sociais a gente garantiu dentro da fábrica muitas pessoas acidentadas. E eles faziam o quê? Dentro daquilo, quando eles retornavam, eles iam pegar café, carregar folha, papel de escritório, porque estavam com o braço amputado e não 
tinham condições de trabalhar com uma mão. Ou então iam trabalhar no almoxarifado. Tinha caso de pessoas que ficaram cegas dentro da empresa. Então ele ficava dentro de um local mudando folha, fazia-se uma adaptação. Tinha uma coisa que a gente chamava de calibragem de peça. Batia a peça fria para ela ficar na medida. E com essa pessoa, a peça escapou, a ferramenta veio e bateu no óculos de segurança, quebrou o óculos e furou o olho da pessoa. E houve casos que a roldana caiu. Eu estava próximo de um senhor que se chamava José Joaquim. E a pedra do esmeril estourou e rachou a cabeça dele. E ele caiu trabalhando de um lado e o filho do outro. Matou na hora. A gente pegou o corpo, saiu correndo para o ambulatório e a ambulância já saiu, mas mais tarde veio a notícia que ele havia falecido. Então eram coisas assim que a gente via.

Aí teve outra coisa, que nós trabalhávamos à noite. Aí foram um médico e um advogado do Sindicato na firma. A lei fazia com que o pessoal que trabalhava à noite era 52 minutos, e não 60 minutos. Ele tinha que trabalhar oito minutos a menos que de manhã. E teria que ter uma hora de janta. E nós trabalhávamos direto. Então pegávamos das dezoito horas às seis da manhã. Estava totalmente errado. Aí a firma teve que fazer uma adaptação nesse horário. Então o pessoal entrava às dez horas, tinha uma de almoço. E com isso tinha insalubridade, tinha uma série de coisas acrescentadas ao salário. E aí começou a fazer um outro horário. Nós entrávamos no domingo e saíamos sábado de manhã. Então a adaptação foi que a gente entrava às onze horas e saía às seis da manhã. E tínhamos um intervalo de uma hora de almoço. Então diminuiu. Aí a maioria queria trabalhar à noite porque trabalhava menos [risos]. E aí começou o revezamento. Aí ficou um espaço da firma, porque o trabalhava umas quatro ou cinco horas a menos. Porque fazia doze horas, seriam quatro horas extras. Passou a ter uma redução bem grande. Não daria umas cinco, oito horas. Eu sei que trabalhava das onze às seis, e com uma hora de almoço. Onze, doze, meia-noite, uma, duas, três, quatro, cinco, seis - passou a trabalhar seis horas o noturno. Então isso deu uma redução muito boa. E aí o pessoal dormiu até um pouco mais. Porque se adaptava para dormir na parte da tarde. Dormia até nove horas da noite. Aí levantava, tomava banho e ia trabalhar. Então tinha um intervalo muito bom para o pessoal dormir, porque tinha um pedaço da noite. Então aí não dava sono. Mas quando eram doze horas era muito puxado. Muita gente se acidentava por isso. Eram doze horas de serviço. Num trabalho com muita caloria. Acontecia o seguinte: quando a gente parava de trabalhar, tanto na parte de inspeção quanto o pessoal que era forjador, no outro dia, quando a roupa da gente secava, você batia nela e caía sal, de tanto que a gente transpirava. A água, se não fosse gelada, a gente não conseguia tomar. Mesmo a água natural, se fosse tomar a gente sentia quente. Então tomava água gelada. Na forjaria, você não consegue tomar água normal. Tem que tomar água gelada para senti-la normal, de tanto calor que era.

Wilson, sobre o trabalho na fábrica, o que você lembra?

Eu entrei como ajudante dentro da fábrica. Fiz o SENAI, e aí passei a ser inspetor de qualidade. Eu nunca fui um cara de entregar amigos, colegas. Eu nunca fui esse cara. Eu procurei sempre ter amizade. Eu achava que o importante da gente era ter amizade com as pessoas. Então a gente via as pessoas: “Não fui eu, foi Fulano. Não fui eu, foi ele”. A pessoa fazia um tipo de peça, e quando tinha algum problema, ele jogava a culpa sempre no outro, 
nunca era ele. Eu sempre assumi meu erro, porque eu achava que era injusto você fazer uma coisa errada e não assumir. Até para aprender. Da outra vez você não faz.

E eu consegui passar de ajudante para inspetor de qualidade. Trabalhei no que eles chamavam de inspeção final, onde a gente olhava as peças com defeito. Media a peça $e$ mandava para a expedição, que era a embalagem, e daí já ia para a venda. E com esse conhecimento fui trabalhar na usinagem, aprender a traçar peças. Peças brutas, peças usinadas. Então eu aprendi essa traçagem. Dessa traçagem eu vou trabalhar na forjaria. No forjamento eram aquelas peças quentes. Então tinha que esfriá-las para ver se estavam na medida, se tinham trincas. E depois fui trabalhar como inspetor de ferramentaria. Fui trabalhar como inspetor de ferramentaria, e de ferramentaria passei a traçagem de gesso. $O$ gesso tinha que estar com a medida certa, não podia estar errada. E quando veio o retroprojetor, eu fui trabalhar com ele. Porque no SENAI eu conheci o retro-projetor, e o pessoal que tinha SENAI antes de mim não tinha conhecimento do retro-projetor. No retro-projetor você colocava o desenho, colocava a peça e ia conferir as medidas, se batia a peça com o desenho. E o desenho da ferramentaria era ao contrário. Então você tinha que aprender a ler o desenho ao contrário. Então eram coisas totalmente diferentes. Depois eu fui trabalhar com alumínio, e a temperatura do alumínio. O forno do alumínio não poderia ter uma caloria muito elevada, porque dependendo da elevação da caloria, o próprio alumínio trincava na hora de prensar. Então tinha que medir a temperatura do forno a toda hora, e trabalhava com aparelho, não tinha termômetro. Era um aparelhinho para medir. Era um termômetro, mas era um termômetro que a gente pendurava no ombro, e com uma varinha media a caloria do forno. Então se tivesse alta pedia para abaixar, se estivesse baixa pedia para aumentar. E media a temperatura da matriz, porque fazia o molde no martelete, voltava para o forno, e quando ele estava na temperatura que ia para... Então tinha que ter muito cuidado para o material não trincar. Muitas vezes o próprio inspetor de qualidade se apavorava na caloria. E acabava deixando muito alumínio estourar. Ficava apavorado, nervoso com aquela questão. Eu tinha essa tranqüilidade de trabalhar.

Até hoje, em função da AMA, do número de pessoas na AMA. Não foi só da Forjaria e da Mercedes que eu fiz amizades, mas em outras fábricas também. Devido a muitos seminários, muitos encontros, de levar jornal na porta das fábricas. Eu saía da Forjaria e ia para portas de outras fábricas. Teve uma vez que eu entrava das sete às cinco. Então eu saía de casa às cinco horas da manhã, vinha para o Sindicato e depois ia para a porta de outras fábricas para entregar a Tribuna Metalúrgica, junto com os diretores. Então nisso a gente pegou conhecimento. Então é essa amizade que a gente tem, esse conhecimento. O pessoal vem aqui, bate um papo, dá risada, conta casos do que aconteceu. Isso é muito gratificante, porque as pessoas vêm aqui na Associação, quer saber se a gente ainda está aqui, se encontra com a gente, vêm, aqui para sentar, dar risada. Você viu agora, você presenciou o pessoal vindo aqui para conversar com a gente.

E outra coisa, a pessoa sobre quem a gente estava falando é um chefe de sessão, que chegou a ser supervisor. E quer que a gente desça para lá. A gente que era de comissão de fábrica, ligado ao Sindicato. Então você vê que não era uma diferença que a gente tinha. Na Mercedes-Benz eu tinha uma questão: eu era da comissão de fábrica. E no distrito eu ia de máquina em máquina cumprimentando o pessoal, vendo o que poderia melhorar. Fazia relatórios, entregava para a empresa. Muitas vezes o pessoal tinha um problema, a máquina 
estava com problema e a chefia com aquela questão de produção, produção e produção. Eu conversava com o chefe e falava: "Estou fazendo um relatório assim e assim”. Ele falava: "É até bom que você faça porque eu sou pressionado lá em cima para dar produção aqui. Você fazendo um relatório eles olham para isso". Então com isso a gente adquiriu confiança tanto na empresa quanto com a chefia. E hoje aqui na Associação a gente não faz distinção. E nem na fábrica fazia. Porque eu achava o seguinte: o chefe estava ali representando a empresa, ele adquiriu o cargo para tomar conta de um departamento. O operário estava lá para trabalhar e a gente também. Não para ter o confronto. Esse negócio de xingar um e xingar outro, como muitas vezes a gente viu. $O$ dirigente sindical xingando na porta da fábrica. Eu nunca fiz isso. Eu chegava na pessoa e conversava com a pessoa. Achava melhor assim.

E a gente teve algumas conquistas, algumas gratificações. Algumas amizades que a gente conquistou dentro da empresa. E eu chego hoje na Mercedes e não preciso nem de carteirinha, nem anotar meu nome. Eu chego lá e o pessoal já manda para dentro. Então isso para a gente é gratificante. Sem precisar entregar amigo, ou quem quer que seja.

Como eram as condições de trabalho na fábrica? Questão de higiene e segurança.

A Forjaria São Bernardo não era boa na questão de higiene. No início, quando eu entrei, a gente comprava luva, o sapatão, o macacão, o óculos, e tudo. Era tudo descontado no pagamento. $O$ avental. Eles chegavam até a cobrar a tenaz. Eu não cheguei a trabalhar com a tenaz no forjamento, mas até a tenaz era cobrada.

Tenaz é o quê?

Tenaz é um alicate grande para pegar peça quente. Tinha a perneira, que é um tipo de bota que era de couro, não de PVC. E o pessoal pagava.

Você ia ao banheiro e não tinha papel higiênico. Você tinha que se virar. Levar de casa, arrumar, se virar. E o cafezinho havia, mas você tinha aquela hora para tomar o café. Tinha que levar marmita. Não tinha espiriteira para esquentar a marmita. A gente colocava a marmita na caixa quente e ficava de olho, porque a empilhadeira vinha pegar a caixa, $e$ levava a marmita do cara junto. [risos] Ou então colocava em cima do forno, no equipamento de produção, e ficava esperando a marmita esquentar.

As luvas de couro que a gente usava deveriam ser trocadas a cada quinze dias. Mas às vezes a pessoa estava com a luva toda rasgada, toda furada. Dependendo da peça que vinha com rebarba, a luva furava. E o pessoal não podia trocar, porque só podia trocar de quinze em quinze dias, e ainda era cobrado no salário. Tinha um período para trocar a luva. Se alguém pegasse seus óculos, seu sapatão. Muitas vezes a pessoa não tinha nem sapato para ir trabalhar, não tinha nem chinelo de dedo na época. Às vezes era aquele chinelinho de couro, tipo nordeste. Muitas vezes o pessoal vinha com aquele chinelinho. Aí o cara pegava aquele sapatão, pintava de outra cor. Aí não podia provar que era do outro cara. Então tinha que ter um cuidado violento. Ia tomar banho, tinha que trancar o armário. Colocava tudo dentro do armário e levava a chave para o banheiro. Chegava lá era uma confusão, porque tinha umas duas ou três chaves, sabonete, todo mundo tomando banho. Eu fazia o seguinte: esperava todo mundo tomar banho, porque eu não pegava ônibus. Aí tomava banho tranqüilo, e depois eu ia embora. 
Na Mercedes era mais controlado, porque já tinha um cara no banheiro para limpar, tinha papel higiênico. O cafezinho tinha. Não tinha pão, mas tinha o café. Tinha cantina. Você podia ir lá comprar o pão, comprar um lanche. Ou então o próprio faxineiro da sessão fazia isso. Você comprava o vale, depois ele ia lá com o vale. Tinha a cantininha, você entregava o vale do leite, o vale do pão, pão com manteiga, pão com queijo. Cada um tinha um valor. E aí você se alimentava. Na hora do almoço, se você quisesse fazer um lanche, que era costume de todo o pessoal, fazia. Vinha um guardanapo, você fazia o lanche no guardanapo. E antes de ir embora você comia aquele lanche. Então não Mercedes era mais controlado. Tinha uma higiene melhor. As sessões eram mais limpas. Quando chegava na sexta-feira o pessoal fazia aquela faxina. Parava a sessão na sexta-feira e já limpava, pintava. A cada quinze dias eles pintavam o setor. Mas era lavado toda semana. E aí lavava, e vinham enxugando com serragem. Passavam serragem, depois o pessoal vinha com a máquina. Então a gente como inspetor limpava todo aparelho de medição. Limpava o local onde a gente estava. E o pessoal lavava o setor.

Mas, por exemplo na Forjaria, onde as condições eram piores, vocês reivindicavam melhorias?

A gente brigou muito na Forjaria. Melhores condições de trabalho. A gente conquistou o macacão. A gente passou a não pagar mais o macacão, o sapatão. E quando rasgava, a gente ia lá e trocava. Então houve uma certa mudança. Tivemos muitas conquistas na Forjaria São Bernardo. A gente falava: era a idade da pedra. Você tem que trabalhar com aquilo que o pessoal determina. Então, com essa mudança, a gente acabou conquistando muita coisa. Hoje tem empresa que lava até a roupa dos funcionários. Mas naquela época, além de lavar a roupa, a gente tinha que pagar por ela. Então a gente teve essa conquista. Houve uma mudança muito grande. O layout da empresa também mudou muito. A partir do momento que o sindicato começou a entrar dentro da empresa, foi ajudando a mudar o layout, para ficar muito mais tranqüilo para as pessoas trabalhar, para trabalhar mais folgado. Antes era uma maquina em cima da outra. Houve algumas idéias dentro do Sindicato que acabaram em uma mudança no layout da empresa.

Sobre o Sindicato, o que você lembra dessa época?

O Sindicato, como eu disse para você... quando eu fiquei sócio, o presidente era o Paulo Vidal. Depois, em setenta e quatro... em setenta e... [pausa para lembrar]. Em 76, se não me engano, foi a primeira eleição do Lula. O mandato era de dois anos. Foi em 76 e em 78 que o Lula foi eleito. Foi eleito duas vezes. Aí depois, em 80, veio o Jair Menegueli. Mas aí ele já veio dentro de uma trajetória de um curso, um ensinamento pessoal. Dos cursos que o Sindicato deu eu fiz todos. Só se tiver um novo, agora, que a gente não sabe. Eu tenho mais diploma do Sindicato, de cursos, seminários, formação de formadores, formadores de formadores. Tive presença dando aula no Sindicato, na escola do Sindicato, de OSPB. Fiz o curso de expressão e oratória, dentro do Sindicato.

Na realidade o Sindicato é uma escola. Aí você começa a se apaixonar por aquilo. Começa a lutar com mais garra, mais força. Começa a conhecer aquela mudança de ter um conhecimento maior. E começa a se apaixonar pela luta, porque ela é gratificante. Não a luta por si, você lutar para você. Mas lutar pela comunidade. Então, se tem algum problema, você 
ir atrás, a maioria dos sindicalistas tem isso. Ele passa a pertencer ao sindicato, ele passa a defender. E passa a não ficar mais quieto diante das injustiças. Então, se uma pessoa está maltratando a outra, você tem aquele instinto que já fala. Você pensa, fala, não para atingir o agressor, mas para ele compreender que ele está errado fazendo aquilo, para que ele adquira o respeito à outra pessoa. Então, o sindicalista, quando começa a fazer parte, ele tem muito isso, de defender o próximo.

Muitas vezes eu falo para o pessoal: você faz uma assembléia, você conversa com as pessoas, você dá conselho para a pessoa, e quando você chega em casa, você não é capaz de falar isso. [risos] Então, quando chega em casa, bate aquela coisa. Aquilo que você consegue conquistar na rua, falar, mudar, quando chega em casa, a mulher tem tanto argumento, que você fica parado. Você não tem o argumento contra aquilo que ela está falando. Por quê? Porque você deixa de fazer compras, você deixa de fazer algumas coisas dentro de casa, em prol à luta. E não há uma compreensão dentro de casa que você está fazendo aquilo para o próximo, para todos. Que você quer mudar a sociedade. Então, dirigente sindical, quando está dentro do sindicato, ele está lutando não para si. Ele está lutando porque a ideologia dele é mudar a história da humanidade. É colaborar para mudar a história da humanidade, para as pessoas terem condições de vida melhores. Ele pensa nisso, ele vem para isso. Naturalmente que muita gente vem pensando que vai ter outro salário, pensando que vai ficar bem na vida. Mas quando ele vem com essa intenção e vê que não é isso, que ele não vai mais ter seu domingo, seu sábado, não vai mais poder ficar com a família, vai ter que participar de um seminário, vai participar de uma palestra, ele começa a ter problemas em casa. A vida dele era ir para a praia, a vida dele era visitar a família, ir ao Playcenter, ir almoçar em um restaurante. E de repente ele se vê preso dentro de um sindicato, e a família cobrando. Aí é onde começa a ter um conflito dentro de casa. E ele não sabe administrar isso. Muitas vezes a gente tem falado no sindicato: traga a família para dentro, para conversar. Deveriam fazer um seminário com as esposas dos dirigentes, até para elas entenderem qual é a função do dirigente sindical. E muitas vezes isso não é feito. Uma ou outra esposa entende. Mas isso é onde dá muita separação de dirigente sindical. A grande maioria é separado.

Wilson, você fez parte de algum movimento de bairro? Ou algum movimento ligado à igreja? Não, ligado à igreja não. Eu fiz parte de movimento de bairro. Eu fiz parte de conselho de bairro aqui na Ferrazópolis. Fui coordenador do núcleo do bairro de Ferrazópolis. A gente teve muitas discussões, muitos debates, trazia muitas pessoas.

Eu sou uma pessoa que busca alguém para fazer palestras. Então, sempre alguém para desenvolver algum trabalho. Se tem alguma coisa, eu trago. E dentro do bairro, no núcleo, tinha uma época que a gente não tinha nem lugar para o pessoal ficar dentro. $O$ pessoal ficava na rua. Sempre vinha muita gente, porque a gente sempre trazia alguém para falar. E aqui na Associação eu também faço isso. Toda assembléia nossa tem alguém para falar de um assunto ou de outro. Abre a palavra para perguntas. Isso traz o pessoal. E quando a gente pode, a gente faz alguma coisa assim. Tipo, a Caixa virá agora no dia 28. Dá para fazer um café da manhã? Dá. Aí eu convido o pessoal para vir de manhã. Aí tem frutas e outras coisas. Aí vem outro pessoal: "Dá para vocês pagarem um coquetel?" "Dá". Então essas doações a gente corre atrás. Aí vê um pessoal: "Olha, você é enfermeira, você pode medir a pressão do pessoal?”. Cada assembléia nossa tem uma coisa diferente. Na 
assembléia passada teve o Deputado Vicentinho. Veio aqui, falou com o pessoal, teve a questão da mulher, do dia internacional da mulher. Teve um deficiente visual, que falou sobre a questão do preconceito sofrido por eles.

E no bairro não era diferente. Eu fiz parte de comissão de escola, no bairro Ferrazópolis. A gente tentou, junto com os professores, mudar o ensino na escola. Muitas vezes o diretor vê o aluno que mora na favela como um marginal. E muitas vezes não é na favela que está o marginal. Ele está na família de classe média, ou de classe média-alta. Então a gente via muito essas coisas, de conversa com o pessoal. Eles confundiam muito o cara que era o brincalhão, ou o bagunceiro, como eles diziam, com um garoto de favela que é traficante. Tinha muito isso. E a gente conversava com o aluno. Fizemos campeonatos de classe, fizemos festa junina. A gente procurou trazer todos os garotos. Aí, quando muda a diretoria, muda tudo. Um aceita, outro não aceita. Depois que mudou a diretoria, a diretora nova achou melhor trazer um ex-sargento reformado para dentro da escola, para tomar conta. E acabou com o conselho. E numa dessas, tinha prova, o menino chegou atrasado. Apavorado, porque ela mandou trancar o portão. Ele tenta pular o mura, e naquilo que ele tenta pular o muro, o policial atira. Aífoi protesto, e todas essas coisas, e tiraram a diretora.

Outra coisa, é que acontece o seguinte: quanto mais burro, melhor. Então a lei do estado é a seguinte: o cara não pode ter entendimento, ele tem que passar a matéria. Se ele entendeu, entendeu. Se não entendeu, passa por presença. E não é isso que a gente quer. No meu tempo você decorava. No meu tempo de escola, você decorava a tabuada, o questionário. Você tinha que responder ao questionário, você tinha prova oral, você tinha que ir lá na frente, responder, falar a tabuada. Você tinha que decorar, fazer o dever de casa. Hoje muitas vezes gente não vê isso. Não tem dever de casa, faz só aquilo, e muitas vezes escreve mal. Não que a gente é expert nessas coisas. Mas a gente vê que nossos filhos pouco sabem os heróis brasileiros. Aí falam que a educação tem que ser em casa. Tudo bem. Mas a escola não ensina mais como deveria ensinar. Não é questão de educação, que a educação vem do berço. A escola é um complemento. Mas é um ensinamento para o cidadão ter um conhecimento do seu país. E isso não está acontecendo. E a gente procura ter esse acompanhamento. Hoje não tanto, porque a AMA ocupa muito tempo. Mas, de vez em quando eu vou à escola da minha filha. Então a gente vê que o ensino teve uma queda muito grande.

E sobre partido político? Você fazia parte de algum na época?

Eu faço parte até hoje do Partido dos Trabalhadores. Sou filiado.

Você participou da fundação?

$N a$ realidade eu participei da reunião de fundação do partido. Eu participei da reunião. $O$ partido nasce em 80. Mas eu venho a me filiar ao partido em 84, quatro anos depois de sua fundação. Aí eu me filiei ao partido, e continuo até hoje. Apoiei vários vereadores, fui coordenador de campanha de vereador. Hoje ele não está nem mais no partido, saiu fora. Mas eu continuei no partido. Eu fiz parte da direção do partido. Tive essa militância.

Muita gente me convidou para sair do partido. Eu achei que deveria me manter. Por quê? Quando eu sai $r$ desse, eu acredito que não vou me dar bem em outro. Então eu fico nesse. 
Aqui dentro da Associação muita gente sabe que eu sou do Partido dos Trabalhadores. Uma boa parte da diretoria é do partido, outros são simpatizantes. O Zé Fernandes era do PCML, que é uma outra corrente do "Pecezão". Deu um racha, e formaram o PCML.

E no Partido dos Trabalhadores eu sempre estive atuante. Assim como no Sindicato e na CUT, eu participo de seminário, de encontro do partido, de assembléias. Eu tenho sempre participado. Tenho conhecimento com vários outros partidos, mas eu não tive interesse em entrar, buscar estatuto. O Partido dos Trabalhadores tem estatuto, regimento interno. Então eu tenho conhecimento mais profundo.

No seu ponto de vista, quais foram as repercussões das greves na vida dos trabalhadores? O que mudou depois das greves?

Muita coisa mudou. O respeito aos trabalhadores, que não tinha. Antes das greves, a própria chefia batia no peito e falava: "Eu te mando embora a qualquer momento". Xingava. Teve caso que a gente soube de chefe que dava tapa na cara do operário. Após a greve isso foi mudando. O trabalhador passou a ter direito, passou a conversar, passou a opinar. Passou a ter uma série de coisas que antes ele não era ouvido. Antes ele dava opinião para melhorar, $e$ o pessoal não queria melhorar porque dizia que trabalhador não tinha que opinar, tinha que trabalhar. E o respeito ao trabalho, ao trabalhador, hoje, as empresas entendem. Elas procuraram melhorar seus quadros de RH, de chefia. Então, fazer um trabalho em grupo, fazendo cursos com chefias. O modo de tratar o trabalhador. Ele vivia mais na fábrica que em casa, então seria uma mudança necessária. Esse respeito foi uma grande mudança que houve com os trabalhadores.

Você ainda encontra muitos companheiros que estavam nas greves, né? Vocês conversam, relembram?

Sim, sim. A gente viveu aquele momento. Muitos casos aconteceram, a gente dá risada. Ficou a amizade. Ficou muito a amizade de companheiros. Isso é muito gratificante.

E tem mais alguma coisa que você queira acrescentar sobre as greves? Algo que você acha relevante, e não falou?

$O$ que a gente praticamente vê é que a direção do Sindicato hoje é formada praticamente pelos filhos dos metalúrgicos, dos antigos diretores. E a gente vê o seguinte: aquela união, aquele debate, aquelas conversações que tinha, a vontade de mudança, tudo isso continua. Dá a mesma seqüência, o mesmo tom. A gente vê que a escolha da formação de chapa, a escolha da direção, vem vindo em um patamar de honestidade, de igualdade, de companheirismo. Isso a gente vê no Sindicato dos metalúrgicos. Eu não vou dizer que isso acontece nos outros, porque eu não tenho a convivência. Mas a gente vê que esse sindicato aqui mantém esse padrão de discussão, que vem dentro daquele patamar que o Lula desenvolveu na época, que era não ficar só enfiado dentro do sindicato, mas ir para a base, discutir com a base. E a base sabe quem são os dirigentes sindicais. Então, um vai para a porta da empresa do outro. Faz aquele revezamento. Não precisa gravar todos os dirigentes. Mas pelo menos a grande maioria o pessoal fica conhecendo. Isso é uma coisa que o 
sindicato ainda conserva, essa unidade da diretoria. $O$ reconhecimento da peãozada com o dirigente sindical.

Para terminar, o que você achou de dar essa entrevista, de relembrar as coisas? Como você se sentiu?

Eu achei que foi bacana. A gente relembra o passado que a gente viveu. Eu costumo sempre falar para as pessoas o seguinte: faça sua história, não deixe que os outros contem. Porque quando o outro conta, ele não conta direito, ele conta mal. Então construindo sua, você está sempre contando aquilo que você viveu, que você presenciou. Isso é fundamental. Você dar a entrevista, o depoimento, ver aquilo pelo que você passou, a mudança que teve, tudo isso é uma coisa gratificante para a gente, porque a gente está aqui para dar o testemunho do que foi nossa vida naquele momento de greve, de trabalho, de tudo o que acontece no contexto das greves dos metalúrgicos. Então, para a gente, é gratificante quando você vem aqui e faz a entrevista com a gente. E sei que você vai levar e apresentar para algumas pessoas. Não só o meu depoimento, mas o depoimento de muitas pessoas. É muito ruim quando alguém inventa a coisa e fala para você. E é gratificante também para você quando a gente mostra tudo aquilo que a gente viveu.

Tem muito mais coisas que a gente não lembra na hora. Tem momentos tristes, momentos alegres. Como eu disse, teve companheiro que morreu, teve companheiro que perdeu o braço. E a gente está aqui para contar o que aconteceu no dia-a-dia com a gente. Eu sempre falo para o pessoal o seguinte: agradeço a Deus por ter pequenas seqüelas. Eu perdi um por cento do ouvido direito e meio por cento do esquerdo. Mas eu procurava sempre me cuidar. Não tinha EPI, colocava algodão no ouvido. O pessoal perguntava: pra que isso? Porque o barulho era muito grande. Sempre usando o equipamento, chego hoje aos 57 anos e meio, graças a Deus, com saúde. Trabalhando com veneno, química, tudo. Mas a gente procurou ter cuidado para chegar a essa idade. Daqui pra lá é outra coisa. [risos]

\subsection{Nelson}

[Nelson começa a falar sem eu fazer qualquer pergunta, assim que ligo o gravador]

Meu horário de trabalhar era às seis horas. Saía de casa às cinco horas e ia trabalhar. Então, na greve, a gente parava as máquinas. De greve! A gente saía, todo mundo, e ia para a assembléia, e ficava até meio-dia. Meio-dia a gente ia para casa almoçar, e depois voltava para a assembléia. Depois da assembléia ia para a igreja. Aí era aquele tumulto de gente. Tinha polícia militar, polícia civil, metendo o cacete. De noite ia embora para casa, e no outro dia era a mesma coisa.

Fazia piquete, porque tem muitos pelegos, que querem entrar para trabalhar. A gente tirava os pelegos de dentro do ônibus para ninguém trabalhar. E ninguém trabalhava. E aí voltava para a assembléia. Passavam aqueles aviões por cima, com aquelas metralhadoras, $e$ 
o Lula falando. O Lula falando e aquele barulho: pó, pó pó. E aí ia para casa. Voltava, e ia para a assembléia. Ficava até às cinco horas, e depois voltava para casa. "Hoje encerrou". No outro dia, a mesma luta. Sentava em cima da máquina. Eu era preparador de peça. Com a lima, [imita o som de alguma coisa que não sei bem o que é] e falava: "Hoje ninguém trabalha!". E começava a mesma luta. Mesma luta, mesma luta. E da última vez fizemos às três. Da uma às três. E polícia civil e militar descendo o cacete, e corre, corre, corre. Aqueles brucutus soltavam aquela fumaça, aquele gás, e ficavam todos chorando. Chorando sem querer. E a gente ia para casa.

E no dia que o Lula foi preso, a polícia vinha com os cacetetes. E corre pra lá, corre pra cá. Ali perto das Casas Bahia era um depósito. Era uma garagem. Tinha cada cachorrão grande. E um muro alto, e nós pulávamos o muro, e a polícia atrás. E sempre que passávamos pela Marechal [R. Marechal Deodoro da Fonseca, no centro de São Bernardo do Campo], falávamos para os comerciantes: "Não fecha a porta, não. Não fecha que não somos bandidos”. Tinha uns que por medo fechavam as portas. “Aqui só tem trabalhador”. E nós sempre na luta.

Tem alguma história, algum episódio, que foi mais marcante para você nas greves?

Tem um ex-diretor aí que a polícia pegou, levou preso e meteram o cacetete nele. Ele recuperou. Ele trabalhava na Volks. Deram o serviço para ele e aí ficou limpo. Eu sei que nunca mais eu o vi. A polícia levou muita gente presa. Metiam o cacete. Aqueles que eles pegavam, metiam o cacetete e levavam preso.

Você lembra quais eram as reivindicações dos metalúrgicos nas greves?

Em cima do salário. Era para reajustar nosso salário. Não lembro quanto era, mas era para reivindicar o salário. Era muito pouco que a gente ganhava e a firma não queria dar. E aí nos fizemos essa greve.

Para começar teve o "tartaruga", a gente trabalhava bem devagarzinho. "Hoje é tartaruga!", aí todo mundo trabalhava bem devagar, bem devagarzinho. Eu era da produção. Aí chegava e parava: "Vamos parar, todo mundo!". Aí começava tudo de novo.

Dos seus companheiros na greve, você lembra quem eram as pessoas com quem tinha mais contato?

Os companheiros eram Paulinho... mas a maioria mora muito longe, ou mora em São Paulo. Às vezes a gente vê na hora. Mas eu não lembro mais deles.

Como foi a participação do Sindicato nas greves? Quem eram os diretores?

O presidente eu sei que era o Lula. Mas teve vários diretores no Sindicato. Pelo nome eu não lembro. Agora, o presidente era o Lula. Mas os diretores eu não lembro o nome.

E quando tinha greve o pessoal do Sindicato ia nas fábricas?

Tinha o pessoal de comissão de fábrica. Era palavra de ordem. "Palavra de ordem!" Sempre tinha um com a palavra de ordem. Aí a gente ia seguindo.

O que você lembra das assembléias e reuniões durante as greves? 
Reunião era no Sindicato. O pessoal saía lá da Vila Euclides e ia lá para o Sindicato. Depois nós começávamos a passeata. Aqui no Sindicato, por aqui.

Qual foi a primeira greve que você participou? Como começou, como foi entrar em greve pela primeira vez?

Foi em 80. Teve outra em $69^{8}$. Foi assim: nós estávamos reivindicando reajuste. Os patrões não quiseram pagar. Aí nós começamos a [inaudível]. Aí de manhã vínhamos para o Sindicato. Aí antes de entrar, a gente parava em frente à fábrica. Ficavam todos lá. Aí tinha assembléia na Volkswagen, aí nós entrávamos. Antes de entrar, a gente ficava do lado de fora da Volks. Aí escutava o diretor do Sindicato falar alguma coisa.

Em quais fábricas você trabalhou?

Trabalhei na Volkswagen. Eu era preparador de peças. Preparador de peças tem que saber de tudo. Eu trabalhava com uma lima. E ia para outro serviço, [inaudível] com o grupo meu. Eu não podia trabalhar em outro grupo. No grupo tem mais que preparador de peças. Aí eu exigia mais salário. Meu grupo é tanto, eu não posso preparar mais que isso, porque aí já é outro grupo. Aí não trabalhava, ficava somente no meu, porque meu grupo é contínuo, e naquele ali eu não ia trabalhar.

Como era a função que você exercia? O que você fazia?

O preparador de peças trabalha com uma lima, tirando a rebarba das peças. Tirava a rebarba, para depois ir para a usinagem. Tinha o inspetor que olhava as peças. Se as peças estivessem boas, mandava para a usinagem. Se estavam ruins, ele mandava recuperar. Tinha que mandar para outro serviço. “Essa peça aqui não está boa”, aí passava a lima nela.

Como eram as condições de segurança e higiene na fábrica?

A segurança não era muito boa. Eu estava ali de auxiliar de "cipeiro", quando tinha alguma irregularidade... eu trabalhava embaixo, a comissão era em cima. Quando a máquina estava soltando alguma irregular, descia alguém: "China, vem aqui. Aquela máquina está assim, assim, assado". O titular era o Geraldo, eu era auxiliar. O Geraldo era da usinagem. Aí eu anotava tudo, chegava na chefia: "Tal máquina está assim, assim, assado". "Está bem, pode continuar trabalhando". Mandavam a chefia lá e ele parava a máquina. Aí ficava de quinze dias a um mês parada. Quando eles não paravam a máquina, eu ia falar com o Geraldo: "A máquina está assim e assim”. O Geraldo ia lá e mandava parar a máquina. Tinha uma máquina lá que tinha uma serra. Chegavam os caras lá, pegavam a serra, iam colocar. E os caras só reclamando que se acidentavam. Pedi para colocarem [inaudível]. A serra é muito grande, tem que encaixar. Aí colocaram uma [inaudível, fala o nome de uma peça], descia [imita o barulho da serra descendo], e aí o cara tinha que ter força para encaixar. Aí os caras falavam: "Muito bem, China! Você está trabalhando legal. Muitos caras se machucaram". Muitas coisas eu resolvi.

O pessoal te chamava de China?

\footnotetext{
${ }^{8}$ Nelson provavelmente quis dizer "79".
} 
Me chamavam de China. "Vem aqui, China! Você está com saudade de mim?". Eu subia lá. Meu serviço era produção. Quatro pessoas dependiam do meu serviço. Eu fazia "pá, pá, pá", terminava logo e ficava tranqüilo. Aí eu pegava a prancheta, subia, e os caras: "China, vem aqui. Tem uma máquina assim e assim". O feitor me tirou desse serviço: "Você está andando muito!", "Estou andando, mas todo mundo está trabalhando. Eles dependem do meu serviço". Aí o feitor me tirou do serviço, e me mandou limpar painel. Falei: "Tá bom". Concordei para não brigar. Pegava o cabo de vassoura e colocava uma estopa. "China, como está indo?" "Está indo. Devagar, mas está indo". Era o chefão. Aí ele olhou para mim: “Ah, pô, você não tem jeito, não! Vem para cá. Volta lá para o seu serviço.” [risos] Aí voltei para meu serviço. Eu controlei minha conduta. Porque eu fiz isso? Se a pessoa perder a conduta, brigar, é mandada embora sem direitos. "Você está enrolando aí!", "Estou trabalhando. Trabalhando do meu jeito”. Era um cara grandão, media quase dois metros. Magrinho ele. Ele usava uma capa amarela. "Vem cá, Nelson". Andava bem devagar. Ele reclamava. "Pô, não sou obrigado a correr atrás de você. Eu tenho a perna curtinha, você é grandão".

E na hora de almoço, eu levava suco. Naquela época não tinha Kisuco. Eu comprava laranja e deixava lá. Tinha quinze minutos no almoço e fazia o suco. Ele chegava assim: "Vamos, vamos! Você vai fazer esse suco agora!" "Já está todo mundo trabalhando, não tem ninguém parado lá. Você quer questionar minha conduta? Que é isso? Vai devagar, meu! Deixa eu fazer meu sucozinho". Tinha um negócio desse tamanho de suco [faz gesto comunicando que era um recipiente grande para o suco e ri]. Era um barato.

E como era essa relação sua com o supervisor? Ou feitor...

O feitor? O feitor, você saber, eles querem produção. Aí falava assim para mim: "Você não fez tantas peças!", sempre tem uns pelegos que fazem a mais, "Você não fez tantas peças. Olha o Fulano! Por que você não fez tantas?" Eu falava: "Para mim é qualidade. Quer quantidade? Eu mando quantidade. Mas para mim é qualidade. As peças deles voltam todas. Você quer quantidade? Vou mandar quantidade”. Aí no outro dia mandava: pá, pá, pá! Aí as peças voltavam todas. "A peça voltou!" "Você quer quantidade? Eu mandei quantidade. Os outros mandam mais peças que eu, mas voltam todas as peças. E as minhas não voltam. Mas você quer quantidade, eu mandei quantidade”. Eles queriam produção, mas quatro pessoas dependiam do meu serviço. Eu tinha que mandar qualidade para ter o outro serviço.

O que o Sr. lembra do Sindicato?

Toda a vida eu fui do Sindicato. Doze anos e pouco. O pessoal da comissão de fábrica vinha com um papel: "Quem quer ser sócio do Sindicato?” Eu preenchi aquela ficha. E aí todo mês vinha descontado. Sempre incentivando as pessoas para ser sócio do Sindicato, para lutar pela categoria. Tinha muito pelego que não assinava. Mas a maioria assinou. Tinha muitos que assinavam, mas depois ficavam reclamando do Sindicato. Aí falava para eles que o Sindicato é uma coisa boa para a pessoa, [inaudível] nosso salário, e tem que lutar pelos nossos direitos. Só o Sindicato não vai. Tem que ajudar o Sindicato. "O Sindicato não faz nada”, mas nós temos que ajudar o Sindicato. Aqui na Associação, a gente tem que ajudar a associação. Se não ajudar eles não conseguem fazer nada. 
O Sr. fez parte de algum movimento de bairro, ou movimento ligado à igreja?

Nunca fiz.

E partido político?

Não, não.

Vamos falar um pouquinho sobre você: onde o Sr. nasceu?

Nasci em Pernambuco.

Em qual cidade?

Moreno.

E quando veio para São Bernardo, já veio trabalhar direto na indústria?

Não, eu não vim direto para aqui. Fui para o Rio de Janeiro. No Rio de Janeiro trabalhei em uma fábrica de tinta, como auxiliar de almoxarifado. Tinha que pesar a tinta e o verniz. Então eu trabalhava na área de pesagem. Aí eu pesava para fazer a fórmula certa. Se pesava a mais, dava diferença na tinta. Eu trabalhava nessa área.

Então a firma lá fechou. E eles escolheram os melhores profissionais: "Você quer ir para São Paulo?" "Eu vou”. Deram dois meses. Eu fui trabalhar na fábrica de tintas Lorelei. Ali, perto do Cora. Comecei a trabalhar, e todo fim de semana eu ia para casa. A firma pagava hotel para a turma. No fim de semana ia para o Rio de Janeiro. Deram três meses. Aqueles que não conseguirem, voltam. Eles pagavam as passagens, a mudança. Eu fui o último a conseguir. Eles trouxeram minha mudança todinha. E comecei a trabalhar na fábrica. Em São Paulo eu trabalhei mais ou menos uns dois anos. Então eles conseguiram outra pessoa para pôr no meu lugar. Aí fui tentando encontrar trabalho por aqui. "Você trabalha na Volkswagen?”. Aí um dia eu fui. Fui à noite e consegui o trabalho. No mesmo dia fiz tudinho, todos documentos. No outro dia mesmo já estava trabalhando. Aí fiquei onze anos e pouco, quase dose anos. Aposentei, aí me mandaram embora. Perguntaram: "Você quer continuar aqui?", "Se vocês me derem outro serviço". Porque no serviço que eu fazia ficavam no meu pé. "Ah, você já está aposentado, vai embora!”. Me aposentei, não trabalhei mais.

Desde quando está aposentado?

Desde 85. Vai fazer 23 anos no dia três de julho.

O senhor trabalhou depois disso?

Trabalhei com pintura. Fui ser pintor de parede. Aí pintava apartamento, só por dentro. Quando é por fora, parede alta, não dava. Sempre trabalhei com tinta boa. Duas demãos. Lixava, passava massa corrida, para ficar legal. Mas eu deixei, porque o tempo passa. "Vou parar, porque esse negócio de lixar parede prejudica a saúde. Chega de tinta”. Outra vez fui dormir e a mulher: "Você está cheirando tinta!". Eu trabalhava com verniz, tudinho.

O senhor está com que idade?

Faço 73 no dia três de julho. 
Sobre as greves, quais foram as repercussões da greve na vida do trabalhador? O que mudou depois das greves, no seu ponto de vista?

Mudou muitas coisas. Muitas coisas nós conseguimos, depois da greve de 80. A melhor greve que teve foi a de 80. Nós ficamos 31 dias de greve, eu fui o último a trabalhar. Quando eu cheguei no meu setor, o pessoal já começou: "Vão mandar você embora! Vão mandar você embora!". Mandaram embora outros que eram pelegos, e eu fiquei lá, até aposentar. E consegui muitas coisas. Melhorou em muitos lugares depois daquela greve. Depois veio a CUT também. A CUT trabalha muito pelos trabalhadores. Conseguiram muitas coisas.

Você ainda encontra seus companheiros de greve daquela época?

Eu ainda encontro alguns. Muitos morreram. Outros moram em São Paulo, outros moram na praia. Esse pessoal daqui da AMA não conheci na greve. Do meu tempo muitos já morreram, e muitos moram muito longe.

Mais alguma coisa que você gostaria de falar sobre as greves?

Não lembro de mais nada.

O que você achou de dar a entrevista? Como se sentiu?

Foi a primeira vez, acho que me saí bem. Para falar sobre a greve. Eu sou objetivo. Falo pouco, mas certo.

\subsection{Rafael}

Onde você nasceu?

Nasci no dia três de maio de 1934. Dia três de maio agora estou completando 74 anos de idade. Já estou na automática, já não tem como escapar. Nasci lá no Nordeste, naquele deserto, que não tinha por onde ter uma roça para alimentação. Então, com sete anos de idade, eu fui parar em Presidente Wenceslau, uma cidadezinha no interior de São Paulo. Meu me levou para lá e nós convivemos até os onze, doze anos. Plantava-se muito algodão. Naquele tempo algodão era a renda do agricultor. Nós plantávamos algodão. O sistema de mecanização era o arado. Hoje temos maiores tratores, temos máquinas de alta capacidade. Naquele tempo era o burro, ou o boi. Colocávamos no arado para arrumar a terra para depois plantar o algodão.

Até que chegamos aproximadamente aos dezoito anos e viemos para cá, para o da Penha. Tanto que estive lá hoje. Saí de lá, fui para Carapicuíba, e de Carapicuíba vim fazer a entrevista com você.

Em 1963 trabalhei [inaudível], e não tinha emprego. A mão-de-obra qualificada tinha pouca. De qualificação de mão-de-obra eu entendo, é a pessoa que sabe fazer as coisas. E naquele tempo não tinha qualificação de mão-de-obra. No tempo do boi, do arado e do 
burro, quem tinha, tinha; quem não tinha, não tinha. O capitalismo sempre foi esse que tem aí: quem tinha, tinha; quem não tinha... Mas em 1963, depois desses empreguinhos que tive aí plantando algodão, depois eu vim aqui para a Vila Ré, eu vi num jornalzinho, a Gazeta Esportiva: "[inaudível] do Brasil precisa de caldeireiro que faça traçado geométrico". Traçado geométrico, dentro da caldeiraria, é a vida da mecânica. Em função daquilo, eu que tinha trabalhado em usina de açúcar (meu pai passou da plantação de algodão para a usina de açúcar), eu fui crescendo e entrei na usina de açúcar. Fui acidentado, cortei esse dedo que você está vendo aqui. Foi na Usina São Luiz. Eu posso citar nome, não tem problema não. Eu estava na usina analisando cana quando eu cortei o dedo. De cada caminhão de cana que chega, você retira uma unidade (naquele tempo, agora não sei mais), e passa uma máquina que mói, e você tira a concentração do açúcar na cana. Aí libera o caminhão de cana. Eu fazia isso. Eu mandava a cana para um químico. De Pernambuco vinha muita gente, os maiores químicos nas usinas de açúcar vinham do Nordeste. Era de Pernambuco, de Sergipe. Chamava-se Sr. Faria, eu trabalhava com ele. E foi aí que cortei o dedo. E aí? E naquele tempo era raro fichar uma pessoa. Mas foi por causa do dedo. Eu cortei o dedo e não tinha o que fazer. Então os usineiros... tem até hoje essa usina. Se você for lá, vai ver. Usina São Luiz, umas das maiores do mundo. Naquele tempo eles davam casa para a gente.

Em função disso, o que aconteceu? Meu pai veio para São Paulo e eu fiquei nas usinas. A usina, de acordo com a safra, da quantidade de cana que tem, aumento ou diminui. É de seis em seis meses. São seis meses de reparo, que se chama manutenção preventiva, ou seja, a máquina trabalhou seis meses, desmonta tudo. Faz a retífica e volta a funcionar como era antes. Quando cortei o dedo a Usina São Luís disse: "Agora temos que fichar você". Sabe o que é fichar? Fichar é pegar a carteira profissional. Aí eu tirei a carteira profissional, que é essa aqui. [mostra a carteira profissional] Não tinha outro jeito, se não me fichassem... Foi o Faria, um engenheiro químico que veio do Nordeste. Em Pernambuco tinha várias usinas de açúcar. Então precisava de um engenheiro em São Paulo, vinha de lá. "Você tem que ser fichado, Rafa”. Me chamava de Rafa. Um cara bom, um cara honesto comigo. Eu o chamava de Dr. Faria. Mas não era Dr. Faria, eu chamava assim para puxar o saco, para ajudar. "Vamos fichar!". Peguei e fichei. E foi aí que me deu sorte. E a mulher: "Mas o que é fichar?" "Fichar é ter o registro na carteira”. Foi aí que vim para São Paulo, ali onde é a estação Artur Alvim do metrô.

Naquele tempo era tudo terra por lá. Nós moramos no bairro Jardim Coimbra, se você tiver oportunidade você vai ver. Hoje é uma cidade evoluída. Mas naquele tempo era só barro. Tem um engenheiro da Ford que passou essa semana lá pela rua onde eu morava. Falou que passou por lá e viu uma casinha lá no fundo. E ele entrou em pânico, porque nasceu ali, se criou ali. Eu nunca deixei ele entra em uma fábrica antes da hora. Lá no Jardim Coimbra, onde morávamos, o pessoal era bem simples. Dos seis filhos que eu tenho, cinco eu não deixei que trabalhassem antes da hora. "Gente: escola, escola, escola, escola, escola. Depois tem mais escola. Depois de escola, vai vir o retorno automaticamente”. E o que aconteceu com o Tomás, ele viu a situação da casinha que morava, tão precária e entrou em pânico. Porque olha a qualidade da vida que tem hoje, da casa que ele mora. Hoje a gente chora porque é uma recordação daquele tempo nosso, de criança.

Outra coisa importante é que eu morava lá no Jardim Coimbra, em Artur Alvim, e saía de lá entre três e meia e quatro horas da manhã, pegava um ônibus e descia no metrô 
Belém, ali saía o ônibus da Willis. Saía de lá e vinha para cá. Sentava no ônibus, dormia, o motorista me acordava no pátio da Willis.

É importante saber que as horas extras eram tão aconchegante, tão chamadas pelas indústrias automobilísticas. E também para fazer minha casinha, no meu terreninho. É aquela casinha que meu filho passou por lá. É aquela casinha que meu filho viu e chorou de emoção, porque viu a situação que estamos hoje. Se a gente for ver a situação de hoje, mudou da água para o vinho. E hoje é assim: se eu vejo um coitado jogado na rua, não sei se encosto para dar um incentivo para que vá para a escola e [inaudível] as autoridades. Somos muitos... largados. Por isso que vejo que fui lá para as usinas de açúcar, depois para a Willis... sei lá, que situação.

Naquele tempo, a Willis e a Ford me deram escola, me ajudaram muito, me incentivaram muito. Passei para a área de engenharia aqui na Willis. Trabalhei 32 anos somente em um prédio, nunca saí. As pessoas que trabalhavam aqui, os engenheiros, sempre me incentivaram. E o retorno foi absoluto. Hoje tenho minha casa boa, tenho meu sítio para o lazer, meus filhos, cada um tem o seu carro. Uns trabalham de engenheiro, outro é diretor de um indústria em Indaiatuba, e assim por diante. Em função disso, eu só agradeço e falo: vamos para a escola! Esse negocia de pegar as crianças antes da hora e chegar em uma fábrica para trabalhar meio turno... não, deixa quieto. Ainda que passe um pouquinho de fome, ande com as roupinhas rasgadas, deixe na escola.

Tanto é que eu falei para você? Quantos filhos são? Cinco. Mas eu não escondo, não. Naquele tempo que eu tomava conta do departamento inteiro aqui na Ford do Brasil S. A., eu tinha um caso. E teve uma filha minha. Dra. Andressa, é advogada. Quando nasceu, da mãe eu não quis saber mais, foi uma coisa que deu, uma passagem. Mas a menina é minha filha. Registrada. E também está muito bem, está com sua casa boa, morando lá, e está vivendo.

Mais alguma pergunta para fazer?

Sim. E o Sr. trabalhou na Willis, que virou Ford, de que ano até que ano?

Foi de 1963 até 1994, 95. Deu 32 anos. Trabalhei três anos na Usina São Luiz, que eu comentei, mais 32 aqui, dá 35 anos de serviço. A idade hoje, eu comentei, estou com 74 anos, mas eu me aposentei por tempo de serviço.

E o que o Sr. faz hoje?

Atualmente eu cuido do meu sítio. Estou descansando. Estávamos comentando antes que a aposentadoria no Brasil é sinônimo de fome. Eu tinha um salário muito bom, trabalhava na área de engenharia. Era ativo em função daquilo que eu fazia. E nós lutamos e lutamos em cima disso para ter melhoras. Tanto é que eu comentei com você aquele dia que nós tivemos uma reunião na Praça da Sé, no dia 25, e eu comentei a respeito dos idosos que estão praticamente largados. O salário é baixíssimo para o aposentado, renda baixíssima, doença em cima, saúde não tem. De qualquer forma tem que lutar em cima disso, cobrar das autoridades que façam algumas coisa para a gente que está nessa situação. Quem aposentou em São Bernardo do Campo, que é a capital do automóvel, você sabe muito bem, tem a Ford a Mercedes... Em função disso, se nós tivéssemos tido outro tipo de adiantamento de [inaudível] das coisas, nós teríamos muito mais. E quando tem algum problema que o Sindicato me chama estou sempre na frente. Eu tenho meu sítio, tanto é que estamos para 
fazer uma festa lá. Não é bem uma festa... eu comentei que a vida na roça, quando eu era criança, era uma vida bem retroativa, atrasada. Então nós vamos fazer uma pamonha lá. $O$ pessoal ficou: "Vamos lá, vamos lá!”. Vamos ver se arrumamos uma condução para levar o pessoal para lá, pode ser que o próprio pessoal do Sindicato vá. Mas trabalhar em serviço pesado eu não trabalho. Mas tem que conter muito, porque com a aposentadoria que nós temos não dá para viver. Não dá para viver.

[inaudível], às vezes tinha que trabalhar na manutenção. Nós temos uma sub-estação, nós temos uma caldeira, temos compressores, que são máquinas de alta capacidade, e nós temos [inaudível] para a indústria inteira. E nós temos o restaurante. Sai de greve somente a mão-de-obra da fábrica. O resto, manutenção e segurança, fica. Então eu morava praticamente dentro da fábrica. Quando tinha que fazer hora-extra, eu ligava em casa. Quando não tinha telefone mandava recado. Pegava o cara da companhia e mandava recado: "Não posso ir hoje”. Ficava na fábrica. O Lula, que hoje é nosso presidente da República, é que tratava conosco. Às vezes eu precisava de dez pessoas e pedia vinte. Ele me dava cinco. Aí fechava as portas da fábrica, por lá não passava ninguém, por conta das greves. E eu dentro da fábrica, com o pessoal lá, os seguranças, os guardas e cuidando da caldeira, da sub-estação. 88 mil volts é muita responsabilidade. Hoje nós temos computador. Mas naquele tempo nós tínhamos 88 mil volts que você não podia errar. E eu dentro daquilo lá com meu pessoal, que foi treinado por mim, que eu qualifiquei para mim, vivia menos tempo dentro da minha casa. O pessoal era muito bom para mim. Convivia com esse pessoal o tempo todo. E o sucesso foi absoluto. Prova disso, eu comentei com você, desde que vim do interior até quando aposentei, em 94, trabalhei no mesmo lugar.

Então, levando a vida só tenho o sítio. Meu sítio é muito bom também. Mas eu dependo de outros meios para viver. É muito baixo, como comentamos. Porém, de qualquer forma, no sítio eu descanso.

E sobre as greves, o que você lembra?

As greves, é o seguinte. Vamos ser bem claro. Quando tinha greve, o Lula era o cabeça desse movimento. Mas é aquilo que eu falei: guardas, manutenção, e eu tomava conta da fábrica. E ficava lá. E quando a greve era chamada, parava dentro da fábrica, ninguém falava nada e eu entrava na fábrica. Mas o sucesso vem. Não sei se você concorda com isso. O sucesso vem porque sempre você tem que tomar uma posição. E com esse capitalismo que estamos vivendo, se não for assim você não tem nada. É isso mesmo, acabou, você não tem mais nada. É assim até hoje. Eu comentava com você que meu filho é responsável pela área de produção da Ford. E morava lá naquele lugarzinho que nós tínhamos, aquela situação bem precária. Apesar de ele estar em uma situação mais evoluída, não participou de greve porque nunca teve oportunidade. Tanto que eu falei: "Você só vai para a fábrica quando for a hora de trabalhar”. A ETE, aqui em Santo André, é uma escola técnica muito boa. E eu coloquei meus três filhos lá, para fazer o curso técnico. E o curso técnico, eles vinham chamar em casa. Como comentamos no começo da palestra, é a mão-de-obra qualificada. Aí toma conhecimento, faz um curso superior, e está nas usinas por aí. Nunca participou de greve.

Mas a greve ajudou muito. A greve ajuda muito. Porque se não for assim, vai deixando, deixando, deixando. Eu não participei das greves. Eu comentava com você que seu estava em uma área, e essa área, quando fechava as portas da fábrica, eu ficava dentro da 
fábrica com o pessoal da guarda e da manutenção. Não saíam da fábrica. E quando tinha problema com o presidente Lula, a gente discutia. Eu precisava de dez pessoas, pedia vinte, e ele dava cinco. "Cinco dá para ir?” Não dava, mas a fábrica parada... e assim por diante.

Distribuição de água. Durante as greves nós tínhamos umas bombas de alta potência, pegava água dos [inaudível] e mandava lá em cima para os reservatórios. Quem passava na avenida via lá em cima as torres de armazenamento de água. Então nas greves nós ligávamos as bombas e enchíamos o reservatório lá em cima, e ficávamos jogando dominó, jogando baralho o tempo todo. E a greve lá fora. Passavam dias e dias em greve.

Mas como era para o Sr. estar na fábrica e o pessoal todo em greve?

Nós tínhamos um contato muito bom, Guilherme, em respeito ao episódio. Tanto é que estou aqui, tenho contato com o pessoal. Quem era chefe era chefe. O chefe, com o peão chamado de chão de fábrica... chão de fábrica sabe o que é, né? O pessoal que trabalha na fábrica. $O$ chefe era muito diferente. Eu não, eu mantinha um contato com eles [os peões] de um modo muito bom. Tanto é que até hoje tem gente que vem aí e vem até chorando: "Você lembra de mim? Sou Fulano de Tal. O Sr. de u uma força para mim!" "Lembro, lembro sim!”. Eu era um dos responsáveis pela minha área, e eu sempre treinava do meu jeito. E tinha um sucesso absoluto, não tenho nada que reclamar.

Eu não participei, mas aqueles que participaram recebiam um aumentinho também. Recebiam um aumentinho também. Não era muito, mas recebiam um pouquinho.

O Sr. lembra quais eram as reivindicações nas greves?

As reivindicações... normalmente era salário. Veja bem, as reivindicações normalmente eram salário. E pediam um tanto assim. E como teve várias greves, formam tantas que eu não sei contar... como foram várias greves, ia um pouco, um pouco, um poисо, ит роисо, $e$ multiplicando, quando chega aí aposentado, chega ganhando um pouquinho mais. Porque se eu estivesse numa construção civil hoje, falando de greve e salário, estaria passando fome. Veja esse pessoal. É escola? Mas de qualquer forma se não for escola tem que melhorar um pouquinho, para ficar ruim ainda, porque hoje está ficado péssimo. A situação está péssima. Hoje, para aquele tempo, não melhorou nada. Para quem estava em uma montadora, quem estava de fora comentava a respeito do aumento. Ainda se vivia. Agora, para quem está em outro setor por aí, fabricando peças para as montadoras, é muito limitado.

O que o Sr. lembra da participação do Sindicato nas greves?

O Sindicato, Guilherme, na minha opinião particular, sempre ajudou. Nós tínhamos tantos companheiros, muitos aí ainda conosco, como você vê. Esse presidente de hoje era criança. O Feijóo. Você conhece, né? Ele esteve comigo agora no dia 25. Está sempre com a gente, se tem um problema qualquer, eles chamam, trocam idéia. Se não puder, manda alguém, e assim por diante. O pai dele, quando eu morava em Artur Alvim, naquela distancia do outro lado do mundo, que eu passei por lá ontem, ele morou lá também, na Vila Ré. Mora naqueles lados até hoje.

De qualquer forma, o Sindicato só ajudou, não prejudicou. Se um país não for sindicalizado, ele não tem como sobreviver. Principalmente por causa do capitalismo. Quando você fala nos cubanos, quando você fala em União Soviética... você vê que Cuba é 
uma ilhazinha, um país pequenininho. Só que lá ninguém passa fome, ninguém falta à escola, sem falar outras coisas.

De qualquer forma, a voz do povo é a voz de Deus. Quando eles falaram [inaudível]. Se não for assim, o capitalismo domina tudo. Quando temos um sindicalismo, temos um retorno. Com o capitalismo, não temos o que fazer. Vai embora, não tem mais retorno, $e$ assim por diante.

E me admira que esse sindicato não tinha esse prédio, não tinha nada aqui, em 1963, isso que era praticamente um deserto. Você acha que deixei de pagar o Sindicato? Não. Eu sempre paguei o Sindicato. Os companheiros que trabalhavam comigo, que eram minha equipe, falava para eles: "Vocês podem fazer o que quiser, mas na realidade com o Sindicato o futuro nosso é mais aconchegante. Melhor que ficar na dependência dos outros, pedindo”.

O Sr. falou que ficava na fábrica durante as greves. Então não chegou a sofrer algum tipo de repressão policial...

Nunca. Tinha para fora, mas para dentro da fábrica, não. Prova disso é que o chefe de segurança era um companheiro meu também. E ele não deixava entrar o pessoal, se quisesse quebrar o pau lá fora, tudo bem. Era um pessoal muito humilde. Se fosse hoje era diferente. Hoje está muito evoluído. O pessoal fazia porque não tinha jeito mesmo, não tinha jeito. Então fazia, a gente torcia, eles lutavam, entravam em um acordo, enfim... Até chegar a esse ponto que nós estamos vivendo hoje que é totalmente diferente.

O Sr. chegou a participar de assembléias ou reuniões?

De assembléia não participava. Se fosse hoje até poderia participar. Mas como eu ficava dentro da fábrica, tinha assembléia lá fora. Desligavam as máquinas. Era barulho o dia todo. Hoje tem gente com problema de audição por causa disso aí. São seqüelas. Então desligavam todas as máquinas, era silêncio total. Mas dentro da fábrica eu não me lembro de [inaudível]. Isso eu não lembro de jeito nenhum. Tinha uns companheiros, como o caso do Betão, do Jair Meneguelli, a própria família do presidente do Sindicato... o Feijóo. Eles estavam dentro das fábricas. Eu nunca fiz. Nunca tinha baderna. Que eu vivi, não. Tinha parada. Quando as máquinas paravam, simplesmente era desligado o sistema. Eu trabalhava com alta tensão, distribuindo energia elétrica para a fábrica em geral, para todo o complexo. A fábrica é um complexo, é uma cidade. A fábrica de automóveis é uma cidade. E eu fazia meu serviço. Na hora do almoço tinha um restaurante lá. O pessoal ia lá, almoçava. Mas baderna eu nunca vi. Chegar a quebrar. Mas se mexesse com eles, sim. Esse pessoal era bem humilde. Hoje é mais esclarecido, mais experiente.

Tem algum episódio que foi mais marcante para você no período das greves? Mesmo não participando.

Que eu me lembre... eи não me lembro de nenhum episódio, não. Os episódios que tinham eram na seqüência. Quando terminavam as greves, aceitavam os acordos, ou não aceitavam os acordos. Então os gerentes, que eram da parte elétrica, mecânica e hidráulica, sentavam e falavam "agora é assim, assim e assim", discutíamos. Os próprios supervisores e engenheiros não metiam o pau na greve, não. Quem viu, viu. Quem não viu, acabou a greve, vamos trabalhar. Quando tem greve, pára. Quando não tem greve, vamos trabalhar. 
O presidente da república, o Lula, que naquele tempo era totalmente diferente, participava dos movimentos. Ele que começou a as reivindicações. Apesar de hoje estar com o capitalismo. Com o capitalismo não pode mexer, senão faz uma revolução total. Então quem viu naquele tempo, e quem vê hoje... mudou. Mudou. De qualquer forma de todos os presidentes que nós tivemos, ainda ficaria com ele. Hoje nós estamos aí convivendo com os sem-teto, com os sem-emprego. Você chega em um bar e o cara está tomando uma cerveja, duas três, quatro, cinco cervejas, o problema é dele. Eu não bebo. Então se vai chamar alguém para trabalhar, geralmente é aquele de mais confiança. Tinha cara que era mais radical. Ele queria participar da greve, vai participar da greve. Mas dentre 60, 70 ou 100 pessoas, você acha cinco ou seis. Como eu comentei, eu precisava de 10, pedia vinte. Aqueles que vinham, a gente que escolhia, que eram Fulano, Fulano e Fulano. Os outros saíam e acabou. Quando voltavam, davam continuação e acabou. Nunca mandamos uma pessoa embora por causa de greve. Que eu me lembre, não. Nem se quebrassem. Mas não quebravam, não tinha porque quebrar. Se fosse quebrar ele destruiria. Porque o cara conhece a fábrica. Se fosse o caso de quebrar, ele sabe que bagunça tudo. Imagina que o cara trabalha na sub-estação, de distribuição de força e participar de quebra-quebra. Ele explode tudo. Não tem porquê. Eram caras de confiança, boa gente. Tem outro jeito melhor, se somarmos juntos? Todos juntos. Explicando assim, assim e assim. Dando a informação e buscando informação.

Outra coisa também diz respeito aos idosos. No Brasil os idosos são muito mal qualificados e mal vistos. Temos aqui a AMA, Associação dos Metalúrgicos Aposentados do ABC. Ainda aqui estamos evoluindo. Por aí afora, ficou velho, é simplesmente um trapo qualquer. Não tem quem não quer morrer velho. Concorda comigo? Tem que analisar direitinho, no dia-a-dia. Hoje com 74 anos de idade, com a carteira de identidade na mão, atravesso toda a cidade de São Paulo. Só mostro a identidade, pego ônibus, metrô, e vou embora. Mas tem uns caras que, quando vão me atender é um desacordo total. Mas de qualquer forma quando não estou muito bom falo um palavrão para ele, quando estou vou embora. E assim por diante. Como comentei com você, fui de Artur Alvim até Carapicuíba. E, dada a evolução, que foi o pé de apoio dos próprios sindicatos, melhorou muito do que estava. Mesmo sendo idoso, com uma identidade eu vou e volto. Não precisa nem de carteirinha, é só mostrar a identidade.

Como que era essa história que você contou, que pedia 20 para o Lula e ele te cedia 10 ? É assim: a fábrica era um complexo, uma cidade. A Ford do Brasil. A Ford do exterior eu não conheci, não sei como que era. Mas quando eu precisava de tantas pessoas... eu tinha, vamos supor, 100 pessoas trabalhando na manutenção comigo. Na hora de negociar esse pessoal pra trabalhar comigo, se eu pedisse 20 para ele... eu tratava com ele.

Você tratava com o Lula quantas pessoas ele ia liberar para voltar para o trabalho.

Era com ele, diretamente. Ele: "Não libera esse aí, não. Esse é puxa-saco". De qualquer forma, sempre comigo ele foi muito bom. Tanto é que estou aí. No meio da velharada que você vê, com uma qualidade muito superior. Isso aqui [se refere à AMA]. Lá fora, não. Idoso no Brasil sofre. Eu sempre comento para não nos afastarmos disso aqui, porque quando você chega alguém te conhece. Lá fora, não. É um tiozinho. "Olha o tiozinho aî”. 
Você já falou um pouco, mas me fala o que você lembra do trabalho na fábrica.

Desde que eu comecei na Willis do Brasil, eu tinha muito sucesso. Não tem porque não ter sucesso. Como eu comentei, meu filho passou ontem pela casinha que a gente morava nos fundos. Se emocionou. Falei: "Filho, olha onde nós estamos e o que nós fomos". Naquele tempo eram cinco para eu só cuidar. E eu tinha que trabalhar na fábrica. E às vezes tinha um problema, além da greve, não sei se você concorda comigo, mas quem trabalha em manutenção, você sabe a hora que você chega, mas não sabe a hora de sair. Hora de entrar é às sete da manhã, hora de sair é às cinco. E se quebrar alguma coisa? Vai levantar e vai embora? Não. Vai ficar lá até terminar.

E qual era sua função exatamente?

Supervisor de manutenção. Comecei como peão e saí como supervisor de manutenção e engenharia da fábrica. "Mas você é engenheiro?" Não sou engenheiro. Mas tem muito engenheiros que até hoje me chamar para trocar idéia. A Volkswagen me chamou para ir lá visitar. Quem me atendeu foi meu filho. Eu nem sabia o que era, que ele viria me atender. Aí veio ele.

E no interior é diferente? Não! Têm muitas oficinas de produção, tornearias grandes. O pessoal começou trabalhando comigo, e hoje está lá. Eles chamam, conversam.

O que o Sr. lembra em relação às condições de segurança e higiene na fábrica?

Segurança era 24 horas por dia e higiene era 24 horas por dia. Limpeza, higiene, era desde o papel higiênico. E segurança era desde a sub-estação até quando você vai colocar um [inaudível] num torno qualquer. Para mexer em um torno precisa de mão-de-obra qualificada. Você vê, esses filhos que eu tenho, e minha filha, eram tão dados comigo que eu nunca cheguei encostar... fábrica é a mesma coisa, tem que dar o exemplo. Tem uma turma de cem pessoas, você manda um cara embora para dar exemplo? Não. Você conversa com um, conversa com outro. O cara começa a beber, a não fazer as coisas, chega uma hora tem que chamar... Teve um senhor que uma vez veio chorando: "Você lembra de mim? Eu era viciado, hoje sou crente”. Foi um retorno. Era simplesmente minha obrigação, ele fez a dele. Não tem porque reclamar.

Você fez parte de algum movimento de bairro, ou ligado à igreja?

Fiz. Movimento de bairro fiz parte. Lá no Jardim, Coimbra, em Artur Alvim, todo mundo me conhece lá. Então tinha um negro, de boa qualidade, chamava-se Olavo Monteiro. Nós fundamos um bairro. Aquele bairro lá, onde eu estive ontem, por sinal. Foi um sucesso absoluto. Chega lá e vê a casinha onde nós morávamos. Colávamos os tijolinhos. Fizemos aos poucos, em mutirão. Um terreninho de dez por vinte e cinco, e fim de semana fazíamos as casinhas, aos pouquinhos. A gente ia lá no Ibirapuera, onde era a sede do prefeito. Hoje não é mais. Mas o Olavo nos levava. Desde muito tempo que eu participei de movimento de bairro. Tem que ser unido, se não, não tem jeito. Normalmente o brasileiro é muito sossegado, você concorda comigo? O povo tem que cobrar mais das autoridades. Quando tem um problema, se vai de encontro com o problema, vai buscar a solução do problema. $O$ brasileiro, não. "Ah, vou tomar uma pinga aqui." Se eu tenho um problema e vou de encontro e acho a solução. 
Outra coisa que eu faço e o pessoal entende bem é quando eu faço uma carta. Faço uma carta, pego o ônibus, levo na empresa. Eles vão lá na minha casa, eu discuto, falo. Diaa-dia está mudando, da água para o vinho. Dia-a-dia. No passado, essa coisa ninguém via. Quem foi, foi. Quem não foi , não vai mais.

A greve repercutia no bairro? Havia operários que falavam dela?

No bairro onde eu morava?

Isso.

No bairro onde eu morava, de onde nós mudamos, o Jardim Coimbra, tinha mais ou menos seis, sete. Tomava uma cerveja, comentava, e acabou. Agora, chegava na fábrica, tinha os líderes, que paravam o trabalho. Aí: "Estamos de greve." Não mexia muito com o bairro. Se fosse hoje até mexeria.

Aposentei já tem tantos anos. E hoje mudou da água para o vinho. A tecnologia, que eu não falei. Quem viu o passado e vê hoje, é como se fosse da noite para o dia. Ontem era a noite, que não tinha tecnologia nenhuma. Hoje é o dia. Temos melhores condições, melhores máquinas. Eu não conheço o exterior. Estou falando do Brasil. Você vê que mudou muito. $O$ presidente da república falava da automação. O Lula já falava que a automação ia dar em desemprego. Mas quem está qualificado está cada dia melhor. O computador está chegando, nós estamos recebendo um curso gratuitamente. Ou seja, tem que participar, tem que estar junto, na ativa.

Você fez parte de algum partido político?

Veja bem, já me falaram: "Por que você não sai candidato a vereador?". Não! Os políticos no Brasil são muito acomodados. Esse presidente que entrou está mudando dia-a-dia o Brasil. No entanto não tínhamos outros que eram um zero à esquerda. No tempo do Ademar de Barros. Era do meu tempo.

Mas você faz parte de algum partido, ou já fez?

O partido que eu simpatizo é o PT. Mas se por acaso vier um partido melhor, tudo bem. Tem que dirigir o país com dignidade. O Brasil vai ser uma potência, primeiro mundo. Esse que entrou aí fez coisas que, na minha opinião, foram muito boas. Esse aí que entrou está muito bom. Os outros são tão ruins, mas tão ruins, que eu não tinha como não votar nesse aí.

No seu ponto de vista, quais foram as repercussões das greves na vida do trabalhador? O que mudou depois das greves?

Olha, é bem verdade que muitas vezes, quando vinha a greve, tinha demissões como jeito... agora, não, agora é outra história. Mas vinha a demissão, quando tinha muita pressão. Mas a supervisão, que era meu caso, até a gerência... uma vez que teve uma greve que mandaram muita gente embora, eu tinha um pessoal muito bom. Mas mandei. Não tinha jeito, mandava gente embora.

Você ainda encontra seus companheiros da fábrica? 
De vez em quando eu encontro. Era muita gente. Não lembro de todos. Mas de vez em quando nas reuniões que a gente tem aqui a gente encontra as pessoas. No interior tem muitos engenheiros que trabalharam comigo.

Mais alguma coisa que você gostaria de acrescentar sobre as greves?

A greve não é a solução para o Brasil, a greve só traz prejuízos. A greve só se for o último jeito. Se não tem jeito, vai para a greve. Se não, quando puder negociar e falar, é mais fácil. A greve só traz prejuízos. Pega uma indústria qualquer, uma montadora qualquer, trabalhando 24 horas por dia, de repente fica dez, doze, quinze dias de greve. Não pode. Só se for um caso muito grave.

Para terminar, o que você achou de dar essa entrevista? Como se sentiu em lembrar das coisas?

Foi muito bom. Como eu disse, eu estava em Carapicuíba, e vim correndo para cá, almocei depressa, almocei de pé. A minha mulher: "Você não pode deixar o rapaz esperando". Você não ligou lá em casa, né?

Não.

De qualquer forma tem que ser assim. Conversar. Você que vem de uma USP, começando a vida. A diferença entre uma vida minha e uma vida sua é a diferença da água para o vinho. Você vai ficar como eu. Você vai ficar melhor, porque sua inteligência é maior. Mas você vai escutar a fita. Vai escutar várias vezes, porque eu falo rápido. Mas isso é ótimo. Ótimo, ótimo, ótimo. Se precisar fazer alguma anotação, disponha da gente. 


\section{OS SIGNIFICADOS DA GREVE}

\subsection{As motivações para fazer greve}

Para analisar o significado das greves para os trabalhadores metalúrgicos de São Bernardo do Campo e Diadema, comecemos olhando para as motivações para se entrar em greve. O que teria levado o trabalhador a se declarar grevista? A tentativa de responder a essa pergunta pode nos levar ao início de uma trajetória de formação de significados das greves.

A partir dos depoimentos, percebemos uma multiplicidade de fatores que podem ter levado cada trabalhador, ou um grupo de trabalhadores, a entrar em greve. Muitas vezes fica até difícil para o depoente localizar o momento em que ele conscientemente declarou-se grevista, por tal ou qual motivo. Esses elementos para a análise aparecem espontaneamente no transcorrer da narrativa do depoente, haja vista que nem mesmo foi feita se quer uma única pergunta sobre o que teria levado a pessoa a entrar em greve.

A dificuldade para encontrar as motivações que levaram os metalúrgicos a entrar em greve repousa não apenas na multiplicidade de fatores ou na falta de precisão da localização temporal da decisão de fazer greve, mas também no fato que, por se tratar de um movimento coletivo, as determinações de uma liderança ou de uma diretoria de sindicato pode não ser tão bem compreendida pelo trabalhador, quanto o sofrimento que é sentido no cotidiano duro da fábrica. A esse respeito, Weil (1996) denuncia que "os operários fazem a greve, mas deixam aos militantes o cuidado de estudar o pormenor das reivindicações.” (p. 129). A pensadora referia-se à greve dos metalúrgicos da fábrica na qual trabalhava na França, na década de 1930. E apesar de encontrarmos uma preocupação efetiva de que a base participasse das decisões durante as greves, perceberemos, logo mais, que havia uma distância entre as lideranças e a base, o que seria previsível em uma greve de massas.

Vejamos então alguns trechos das entrevistas que nos trazem pistas sobre as motivações para se fazer greve. Alguns metalúrgicos entrevistados revelam como o sofrimento vivido no cotidiano da fábrica teve ligação direta com a ebulição das greves. As condições de higiene e segurança eram ruins. Juntam-se aí as longas jornadas em ambientes extremamente quentes, resultando em constantes acidentes de trabalho. 
As perseguições no local de trabalho pelas chefias, as condições que você tinha, a jornada excessiva, máquinas péssimas, não existia nada de dispositivo de lei pra te amparar. A própria CIPA era feita pra inglês ver. (Adão)

Pra combater isso, essas questões de máquinas inseguras, o equipamento totalmente inseguro, perseguições, salário super achatado, a questão de higiene, a gente não tinha outro mecanismo a não ser greve. (Adão)

Tinha uma coisa que a gente chamava de calibragem de peça. Batia a peça fria para ela ficar na medida. E com essa pessoa, a peça escapou, a ferramenta veio e bateu no óculos de segurança, quebrou o óculos e furou o olho da pessoa. E houve casos que a roldana caiu. Eu estava próximo de um senhor que se chamava José Joaquim. E a pedra do esmeril estourou e rachou a cabeça dele. E ele cain trabalhando de um lado e o filho do outro. Matou na hora. A gente pegou o corpo, saiu correndo para o ambulatório e a ambulância já saiu, mas mais tarde veio a notícia que ele havia falecido. Então eram coisas assim que a gente via. (Wilson)

O despotismo era a marca das relações dos peões com as chefias. Vejamos alguns trechos a esse respeito:

Porque não tinha diálogo. Nessa época não tinha como dialogar de forma nenhuma. O patrão, os "homi”, ele falou, está falado e acabou. (Adão)

"O meu chefe está pegando no meu pé, o inspetor está pegando no meu pé". Era reclamação de todo tipo, rapaz. Nossa Senhora! "A comida está ruim!” Era uma hora de almoço, aí cortaram, ficou 45 minutos. Era processo atrás de processo, um atrás do outro. Era uma loucura esse Sindicato! (Reinaldo)

Se as condições eram indignas dentro das fábricas, fora delas não era diferente. Os salários sofriam crescente desvalorização. Abramo (1999) e Antunes (1992), como vimos no capítulo 1, são enfáticos em apontar tal desvalorização como fator determinante para que acontecessem as greves, da mesma forma que os seguintes trechos das entrevistas aqui realizadas apontam:

E a gente via no nosso salário a defasagem. E a gente não podia falar nada. E os metalúrgicos, com essa garra e essa coragem, entram de cabeça e conseguem a começar a mudar nos anos 78 e 79. (Wilson) 
Tinha uma coisa que era a seguinte, que o Sindicato fazia assim: a inflação estava em, vamos supor, vinte por cento. Então nós pedíamos oitenta. Vinte por cento de inflação e sessenta por cento de aumento real. Então esse era o lema, para a gente che gar pelo menos nos quinze. Aí tinha as negociações, ficava aquele debate. (Wilson)

E o que acontece? Inflamavam o pessoal. $O$ pessoal já começou a fazer contas. $O$ metalúrgico começou a aprender a fazer cálculo. Então você via no pé da máquina, na hora do almoço, o cara fazendo conta de quanto iria ser o salário dele. E aquilo movimentava. Era um chamariz que a diretoria do Sindicato fez. (Wilson)

Geralmente era ordenado. Só se falava em ganhar bastante. A conversa lá dentro era: “Estou ganhando pouco, estou trabalhando muito”. Todo dia tinha reclamação. (Reinaldo)

Em cima do salário. Era para reajustar nosso salário. Não lembro quanto era, mas era para reivindicar o salário. Era muito pouco que a gente ganhava e a firma não queria dar. E aí nos fizemos essa greve. (Nelson)

O Sindicato dos Metalúrgicos de São Bernardo do Campo e Diadema teve um papel importante na eclosão das greves, embora, como apresentado no capítulo 1, não foi o agente deflagrador das primeiras greves. De uma linha comprometida com o discurso progressista do governo militar da década de 70, o Sindicato vai gradativamente se opondo a esta linha e adotando um discurso de aproximação e mobilização das bases, e de autonomia sindical, juntamente com uma forma de ação que buscava garantir os direitos trabalhistas e a nãodesvalorização salarial (ABRAMO, 1999).

Adão se lembra como entrou em contato com esse Sindicato:

E aconteceu que o Lula montou uma chapa e venceu as eleições no ABC. A partir daí começaram então a vir as problemáticas todas. Foi uma derrota incalculável pra classe patronal. Que eles sabiam que iam mexer com muita coisa, como mexeram mesmo. Se brigava por pouca coisa, tinha que fazer greve. Se fosse necessário, se fazia greve. E aí começou a conscientização. O Sindicato começou a chamar os operários pra ir até a sede do Sindicato. E aí já foram proporcionadas um monte de palestras, de cursos, se criou apostilas, se criou tribunas. Então tudo isso aí era um meio de formação. (Adão)

Em 77 já se começava a falar em possibilidade de greve. Se fosse necessário, se faria greve, sim. Quando esgotassem os recursos, teria que se fazer greve, sim. [...] Durante 
o processo da eleição dele em 76, ele [Lula] já tinha colocado essa proposta de como seria o Sindicato. E se fosse necessário, indiretamente ele já dizia isso, a gente ou teria que fazer greve - só que ele falava em outras palavras - ou a gente fecha esse Sindicato pra não ficar tirando dinheiro do trabalhador, ou o coloca a seu serviço. Isso a gente entendia que tinha que fazer o movimento, e o Sindicato estaria dando o respaldo. (Adão)

É interessante notar como, nos anos antecessores às greves, crescia a indignação dos trabalhadores. Wilson e Adão usam o mesmo termo para descrever a forma que as lideranças grevistas usavam para mobilizar os trabalhadores: inflamar.

Nosso salário estava muito defasado em relação aos gêneros de primeira necessidade, aluguel e outras coisas. As condições de trabalho eram péssimas. A falta de respeito com o trabalhador era muito grande. Cada vez ia indignando mais. A gente costumava usar o vocabulário: inflamando, inflamando. Você imagina uma fogueira, e iam jogando mais combustível. Todas as ações autoritárias que eles tomavam, mesmo a gente não tendo a liberdade de se organizar devido ao regime, gerava muita indignação. Inflamava muito a gente. Cada um que era perseguido, despedido do emprego, apanhava da polícia, ou coisas perecidas, parece que era mais um volume de combustivel que jogavam na fogueira. E a coisa foi se alastrando desse jeito. (Adão)

E o que acontece? Inflamavam o pessoal. O pessoal já começou a fazer contas. $O$ metalúrgico começou a aprender a fazer cálculo. Então você via no pé da máquina, na hora do almoço, o cara fazendo conta de quanto iria ser o salário dele. E aquilo movimentava. (Wilson)

Adão se refere à indignação vinda do sufoco, da opressão sentida pelos operários no cotidiano da fábrica. Wilson refere-se à ação do Sindicato e de algumas lideranças operárias nas fábricas que ensinavam os trabalhadores a fazer cálculos do salário. Em comum, podemos dizer que ambos se referem ao que Adão chamou de fogueira, que era alimentada sem parar por combustível, seja ele a opressão, seja ele a conscientização dessa opressão.

Devemos tentar distinguir, do caldeirão de motivações das greves, aquelas que estão atreladas à primeira grande greve do ciclo grevista. Antunes (1992) define o início do ciclo grevista, em 1978, da seguinte forma: "Em sua efetividade, as Greves de Maio tiveram um claro caráter espontâneo: sua lógica foi ditada pela dura realidade do cotidiano operário, não contando com direção consciente." (p. 32). 
Assim mesmo, segundo o próprio Antunes e alguns entrevistados, como Adão e Wilson, os trabalhadores foram adquirindo experiência em fazer greve. Dessa maneira, as motivações foram mudando, assim como a espontaneidade na sua deflagração. Adão contanos sobre a pauta de reivindicações:

Isso aí mudava, Guilherme, de um ano pra outro. Às vezes, em um ano, dependendo da negociação que acontecia, você eliminava alguma coisa, já estabilizando aquilo por dois anos, três anos, até cinco anos. Então aquilo saía da pauta, e com certeza outros problemas surgiam e já se encaixavam nos pontos de pauta pra se discutir nas próximas... Quando você eliminava alguns itens, com certeza, no processo de negociação, surgiam outros itens, que já se encaixavam na próxima rodada. (Adão)

A espontaneidade dos trabalhadores para fazer greve aparece nos depoimentos quando citadas as paralisações em determinada fábrica ou setor de produção. Nem sempre o Sindicato estava envolvido na deflagração da greve, ou pelo menos não diretamente.

E aí, com essas intimidações, essas repressões todas que houve nessas greves, a gente já não pôde fazer coisas conjuntas. Surgiu a necessidade então de você fazer coisas isoladamente em cada fábrica da categoria. Faziam seus movimentos, criavam seus líderes naqueles lugares. Lógico que era negociado com o Sindicato. A gente nunca deixou de legitimar o Sindicato, porque a gente entendia que era de suma importância a gente ter um sindicato que representasse a gente. Faziam essas negociações, e aí que o pau comia direto, rapaz. Quando se fazia greve em um local isolado, digamos assim que um bairro tem cinco ou seis fábricas. Aí você fez greve em uma fábrica, e as outras estão trabalhando, pra polícia era um prato cheio, porque ela ia atacar só ali. O pau comia solto mesmo. Então a gente teve aquelas greves longas em algumas firmas. (Adão)

A gente fez greve não só nessa época. Na Forjaria São Bernardo a gente fez greve por terem mandado pessoas embora, pessoas doentes. Nós fizemos greve porque, como era forjamento, uma área perigosa, de risco, havia pessoas que perdiam a mão, perdiam parte do braço. Então a firma, na época, não tinha o... como se fala? Não éo contrato coletivo de trabalho. Me fugiu o nome agora. As cláusulas sociais. Então o Sindicato pouco discutia as cláusulas sociais. Depois esse pessoal passou a fazer acordo para ter estabilidade, os que se acidentavam dentro da empresa. (Wilson)

A primeira vez foi por causa do restaurante da Borg. A comida não estava muito boa. Eu trabalhava só à noite lá. Então a comida estava muito ruim. Então nós, inspetores, 
junto com o pessoal da produção, mais os apontadores de produção, combinamos de fazer um boicote ao restaurante, à noite. (Dimas)

A experiência da gente é essa. A gente fala das greves da categoria, das greves gerais de 78, 79 e 80, mas a experiência da gente começa dentro da firma, dentro do chão de fábrica. Essa que é a experiência que a gente tem. É lá que a gente define, é lá que a gente faz. Quando você sai para fora, você sai junto, e já sai sabendo fazer. Já sai preparado. (Dimas)

\subsection{O grau de envolvimento de cada metalúrgico nas greves}

Péssimas condições no local de trabalho, arrocho salarial, repressão policial, sindicato atuante, inflamação das massas, conscientização política, tudo dentro do caldeirão de motivações para se entrar em greve. Podemos perceber assim alguns temperos sutis que estão no depoimento de cada trabalhador. Se há um movimento grevista, que por vezes é um movimento de massa, não devemos deixar de direcionar o olhar para as motivações de cada trabalhador. E em cada depoimento aparecem juntas as relações do indivíduo com seu grupo e as relações do indivíduo com ele mesmo. Cada trabalhador tem uma relação singular com esse movimento que é coletivo. O grau de importância e envolvimento de cada um na greve é variável.

O memorialista entrelaça as marcas de sua vida pessoal com a vida pública. Bosi (1994) diferencia a memória do militante daquele que não se envolve em política, sugerindo que a riqueza de detalhes do primeiro grupo, quando se trata de acontecimentos ligados à política, é muito maior em relação ao segundo. Contudo, não necessariamente as lembranças estão isentas de uma modelagem ideológica, que conduz a uma visão estereotipada do passado. Ainda, segundo a autora, "a lembrança de certos momentos da vida pública (guerras, revoluções, greves...) pode ir além da leitura ideológica que eles provocam na pessoa que recorda. Há um modo de viver os fatos da história, um modo de sofrê-los na carne que os torna indeléveis e os mistura com o cotidiano [...]" (p. 464).

Vejamos como alguns entrevistados mostram, por meio de seus relatos, como as greves dos metalúrgicos do $\mathrm{ABC}$ os atingiam de diferentes maneiras. 
O modo como os metalúrgicos grevistas dedicavam-se as suas famílias, relacionando as greves à vida doméstica, pode ser um termômetro do envolvimento pessoal com a política operária. Adão considera que sua família vai além daquela formada por seus parentes sanguíneos:

Minha família sempre teve muito medo. Pai, irmãos, parentes sempre recomendaram que eu deveria esquecer isso aí. Deixar isso de lado e voltar a cuidar mais da minha vida própria, se dedicar mais à minha própria família, mulher e filhos. Eu sempre dizia a eles o seguinte: "Olha, a minha família, no meu ponto de vista, é muito maior que a família de sangue. Consigo ver que minha família é um pouco mais ampla. Seria covardia resumir a meu mundinho, seis irmãos que nós somos, meu pai e minha mãe. Não que não mereçam, merecem sim toda a atenção. $O$ que a gente pode fazer a gente faz. Mas eu não me sentiria bem, porque eu sei que as conseqüências desse comodismo poderia trazer sérias conseqüências para o coletivo no final. Como eu respeito a particularidade de cada um, peço que vocês me entendam. Me desculpem pelas faltas que eu tenho em casa. Mas não vou abrir mão disso. É uma coisa que eu pretendo continuar. Se por acaso isso trouxer um problema maior, se eu tiver que ser preso, ou mesmo morto, eu não gostaria que vocês chorassem por isso. Porque é uma coisa minha, eu faço com gosto. Ninguém está me obrigando a fazer. Faço porque acredito que um dia a coisa pode mudar. Quem sabe depois dessa mudança, as famílias possam viver a harmonia que vocês querem que eu viva, dentro de uma desordem completa”. (Adão)

Um episódio marcante que apresenta a forma de Adão lidar com a vida pública e a vida privada é narrado por ele:

Nessa greve pesada que estou te falando, da qual nasceu meu filho mais novo, meu filho fui conhecer com três dias de idade. Eu estava ajudando a coordenar essa greve. Então eu entendi que a situação era muito grave, mas muito grave mesmo... eu minto, não foi em 80, foi em 82. A de 80 foi outro caso. E como eu vi que muitas cabeças iam rodar, minha esposa foi para o hospital para dar a luz a esse filho mais novo. Eu falei: "Bom, lá no hospital, está sob os cuidados do médico, tudo beleza. E aqui na fábrica, vai rolar muita cabeça. Então se não tiver alguém com a cabeça no lugar para tentar negociar, e tentar evitar expressões erradas, evitar conversa torta no boteco, vai rolar muita cabeça”. (Adão) 
Wilson também revela a dificuldade do militante em lidar com a vida pública e a vida privada:

Muitas vezes eu falo para o pessoal: você faz uma assembléia, você conversa com as pessoas, você dá conselho para a pessoa, e quando você chega em casa, você não é capaz de falar isso. [risos] Então, quando chega em casa, bate aquela coisa. Aquilo que você consegue conquistar na rua, falar, mudar, quando chega em casa, a mulher tem tanto argumento, que você fica parado. Você não tem o argumento contra aquilo que ela está falando. Por quê?? Porque você deixa de fazer compras, você deixa de fazer algumas coisas dentro de casa, em prol da luta. E não há uma compreensão dentro de casa que você está fazendo aquilo para o próximo, para todos. Que você quer mudar a sociedade. (Wilson)

Dimas chega a dizer que participava de todas as ações do movimento grevista, mas não fala muito da relação de sua vida privada com a greve.

Já Rafael e Reinaldo, por motivos diferentes, não tiveram um envolvimento tão intenso nas greves. Rafael afirma que as greves foram benéficas para os trabalhadores e que o Sindicato dos Metalúrgicos foi fundamental na luta pelos direitos dos mesmos. Mas sua condição de chefe, de um setor vital para o funcionamento da fábrica, o impedia de abandonar o serviço.

E às vezes tinha um problema, além da greve, não sei se você concorda comigo, mas quem trabalha em manutenção, você sabe a hora que você chega, mas não sabe a hora de sair. Hora de entrar é às sete da manhã, hora de sair é às cinco. E se quebrar alguma coisa? Vai levantar e vai embora? Não. Vai ficar lá até terminar. (Rafael)

Já Reinaldo justifica sua menor participação nas greves por conta de uma característica bem pessoal: prezava um bom sono, indo para a cama sempre cedo.

Eu era muito dorminhoco, gostava muito de dormir cedo. Então eles não me escalavam. O pessoal do Sindicato falava: "Ah, você dorme muito cedo. Tem um negócio bom, mas não vou te escalar. Você vai ficar aqui durante o dia conosco, dando expediente aqui, atendendo o pessoal, ajudando na secretaria, atendendo o pessoal no balcão. Mas quando for para fazer essas coisas...”. Quando dava cinco horas, eu saía meio devagarinho e ia embora para casa. Não era contra nada disso. Colaborava. Eu ia nas portas de fábrica, entregar jornalzinho do Sindicato, na hora 
de almoçar. Fazia tudo durante o dia. Mas quando dava quatro e meia, cinco horas, já me despedia. "Pessoal, até amanhã". "Já vai?" "Já”. "Amanhã você vem?" "Venho, venho. Oito horas estou aqui". (Reinaldo)

Reinaldo estava presente nas greves, participando das grandes assembleias e do fundo de greve. Mas se envolveu muito mais na causa dos aposentados, por ter sido escolhido como membro da primeira diretoria da Associação dos Metalúrgicos Aposentados por Lula. Quando aconteceu a primeira greve do ciclo grevista, do final da década de 1970 e início da década de 1980, Reinaldo já estava aposentado.

Outro fato curioso é Reinaldo ser favorável às horas extras, mesmo que a regulação ou supressão das mesmas seja uma bandeira dos trabalhadores.

O Sindicato é contra hora extra. Eles pedem para as pessoas não fazer hora extra. Mas não é de tudo ruim. A hora extra, na visão deles, quando alguém faz hora extra, caberia mais uma pessoa ou duas para trabalhar. Em vez de eu fazer dez, doze, ou quinze horas, poderia se pegar um cara na rua para trabalhar, para fazer mais oito. Nesse lado eles estão certos. A hora extra evita que a firma pegue mais um empregado. Eu concordo com eles. Mas ela não é um mal. A hora extra é um dinheiro que vem a mais no pagamento, e você pode contratar alguém lá fora para fazer algo em sua casa. E com aquele ordenadinho que a gente está acostumado a: recebeu, gastou, recebeu, gastou. Você não consegue fazer nada, fica paralisado. Mas com o extra tem um pouco a mais. Você pega o dinheiro extra, compra um pouco de material, paga o pedreiro, o encanador, o eletricista. Em uma construção precisa de um encanador, de um eletricista. Colocar as caixinhas, passar a fiação, puxar foi, puxar isso, puxar aquilo. No fim, colocar uns espelhos. A construção precisa de muita coisa. [...] E as horas extras ajudavam. Meu Sindicato é contra. Pedem para que a gente não faça as horas extras. Estamos tirando emprego de alguém que passa necessidade, de um pai de família que está gastando sua sola de sapato todo dia e não consegue emprego, porque um serviço que ele ia fazer, nós que estamos lá dentro estamos fazendo nas horas extras. (Reinaldo)

Sader (1988), ao falar da cultura operária nas décadas de 70 e 80, conta como o sonho da casa própria aparecia forte entre os trabalhadores. Atrelado intimamente a projetos da família, este sonho aparece em um lugar de destaque na vida do trabalhador.

A casa bem equipada, com o maior conforto possível, com os sinais visíveis dos resultados dos esforços coletivos, com os enfeites que manifestam os 
gostos dos moradores, constitui o lugar primeiro onde os trabalhadores se reconhecem entre os seus, no seu mundo, livre da impertinência dos chefes, da indiferença dos guichês, da violência das ruas. (SADER, 1988, p. 110).

Esse esforço ao qual Sader se refere é o mesmo que faz com que Reinaldo não ache as horas extras de todo ruim. $\mathrm{O}$ argumento do Sindicato é compreendido e aceito, porém a busca por alcançar um sonho situado no âmbito da família, neste caso, supera o interesse da categoria, ou da classe.

Se compararmos o envolvimento de Reinaldo no movimento grevista com o de Adão, percebemos que não há um padrão de trabalhador grevista. Mesmo considerando que Adão não deixa de lado o sonho familiar (em um trecho de seu depoimento ele declara não ter enfrentado a chefia para não perder o emprego, fonte de sustento de sua família), temos que considerar, ao analisar as memórias das greves, que cada trabalhador está inserido em outros grupos, além do grupo de trabalhadores grevistas. O estudo de Sader (1988) chama a atenção para a diversidade de experiências da classe trabalhadora, bem como a diversidade de possibilidades de atuação política.

Mesmo considerando essa diferença de grau de envolvimento nas greves, podemos apontar alguns temas em comum que são destacados nos depoimentos, como poderemos visualizar na sequência.

\subsection{Significado das greves: os temas a elas ligados}

Afinal, o que podemos perceber que permanece de importante e significativo dessas greves para os metalúrgicos? Quais são as associações que eles fazem às greves? Ao menos alguns temas podemos destacar por estarem presentes em todos, ou em quase todos os depoimentos. 


\subsubsection{A violência}

Primeiramente, podemos destacar a violência em algumas ações grevistas, a qual está geralmente ligada às ações policiais de repressão à greve.

Adão é claro ao se referir sobre o significado de uma greve: Greve é estado de guerra! A violência imposta pela repressão, a dificuldade em mobilizar os companheiros, a dureza patronal nas negociações, são fatores que devem deixar o trabalhador grevista em alerta. Adão lembra dos conselhos que dava aos companheiros:

Aí, uma parte ia pra casa, outra parte ia pro boteco. E pros donos do boteco era uma grande felicidade. Vendiam que era uma beleza. Vendiam muito. E ali, o pessoal já ficava tomando uma, tomando outra, quando dava oito horas que vinha o pessoal administrativo, uma parte entrava, outra parte ia lá pro boteco provocar uma discussão, que era para levantar nomes de pessoas que estavam mais envolvidas no assunto, que era pra levar lá pra dentro. A gente tinha essa preocupação de estar orientando: "Gente, greve é coisa séria! Greve é um estado de guerra. Quando você está de greve, você tem que estar mais consciente que nunca. Quando você não tem que passar a noite toda na luta, tenta dormir, tenta descansar, e se alimentar, porque você está numa guerra, você não pode estar fraco, senão o cara te quebra mesmo. Agora, você vai beber? Você vai estar inconsciente, cara! Você não vai poder estar consciente nem dos atos que você pratica, você vai estar bêbado. Se você for pego pela polícia, além de agitador, você é um cachaceiro também. Bêbado, um incompetente. Vai acabar perdendo seus direitos todos. Vai entregando o ouro todo. Então, tudo que a gente faz, que está fazendo de mobilização aqui, vai por água abaixo, que você vai entregar de bandeja”. (Adão)

A guerra da greve tem espiões, e os trabalhadores devem ficar atentos a eles. Quais são as armas que os grevistas dispõem? Segundo Adão:

Quando tinha uma greve, você tem que ter uma consciência que você está como se fosse um cara que está com uma "metranca" na mão pra meter fogo a qualquer hora. Qual é sua arma? Você não tem nenhuma faca, nenhuma arma explosiva. É seu braço, sua força, sua cabeça, o convencimento. Tinha que usar desses artifícios. (Adão) 
A greve precisa de treinamento para ser bem sucedida. Os trabalhadores que querem lutar pelos seus direitos e por melhores condições de trabalho e vida devem saber como fazêlo. Neste ponto a Igreja Católica, os movimentos de bairro e o Sindicato foram fundamentais. Conforme Adão, aqueles que não estavam conscientes do que faziam acabavam presos, por não saberem como agir. A repressão policial em tempos de regime ditatorial era implacável.

Nós temos entidades aqui, inclusive eu faço parte da direção de uma delas, que teve papel fundamental nisso aí. Isso era feito aos domingos. Não precisava nem fazer hora extra. Aos domingos a gente ia pra lá. Tinha alguém que já tinha estudado um pouco, já tinha avançado, e mostrava pra gente a relação capital e trabalho. Foi quando a gente começou a aprender esse troço aí. Como se dava a relação capital e trabalho, ou seja, a mais-valia. A alta produção, o cansaço do cara, como a empresa lucrava. Isso começou a ser estudado e passado para os operários. Foi fundamental pra abrir a cabeça pra ter uma greve mais organizada. Por isso que a greve de 80 já foi mais organizada. Se tornava quase impossível as empresas e a polícia saber quem era quem. Nessa daí, eu não tenho dúvida nenhuma, que muita gente inocente, principalmente os que não estavam muito de participar de uma reunião no Sindicato, nas comunidades de base, as associações... esses que faziam esse treinamento já estavam um pouco mais livre de sofrer as penalidades porque já sabiam como agir numa greve. Agora esse que não queria nem saber era o primeiro que levava pau. (Adão)

Dimas descreve brevemente como eram os enfrentamentos entre a polícia e os grevistas.

E aqui, no Sindicato, ficou rodeado tropa de choque, polícia de todo jeito. Muitos que estavam aqui dentro tiveram que sair, não deixaram ninguém ficar. Mas o pessoal mesmo assim enfrentou. Até nesse dia eu vim aqui no Sindicato. Mas quando se viu a coisa, a polícia começava a jogar bomba. E aquilo dá uma queimação. Por isso que falam: bomba de efeito moral. Aquilo queima mesmo. Você tem que enfrentar uma cavalaria. Era um rebu danado! (Dimas)

A violência está ligada à repressão imposta durante o regime ditatorial no país. A organização coletiva tinha que acontecer de forma clandestina.

Você não podia estar distribuindo jornalzinho na porta da fábrica, senão os caras prendiam. Mesmo na rua pra você distribuir isso tinha que montar um esquema, 
senão, não funcionava. Você colocava debaixo do braço, ou coisa parecida, deixava cair, o colega que vinha atrás tropeçava, aquilo espalhava, o outro pegava e a notícia começava a espalhar. Você não podia distribuir. Tinha espião em vários lugares e te engaiolavam mesmo e ninguém poderia garantir que você voltava com vida, não. Se os caras pegassem, era muito difícil sair vivo. (Adão)

Mas acho que a repressão policial, nos anos setenta e oitenta foi muito grande, muito perversa. Também por orientação da ditadura militar. Eram anos de ditadura militar, e você não podia expressar nada. Eles davam a ordem e você tinha que obedecer. Os metalúrgicos foram desobedientes, por isso muito apanharam. Eu corri bastante. Nunca cheguei a levar cacetada da polícia, mas corri bastante. Corri e muitas vezes entrava dentro de um lugar, ficava quieto, como se estivesse olhando vitrine. Os caras passavam, e depois, tranqüilo. Mas era uma repressão muito difícil. (Wilson)

Aí nós começamos a fazer nossas assembléias na Igreja Matriz de São Bernardo, nos fundos da paróquia. Houve vez em que o pessoal da polícia, através de investigação, entravam e iam prender as pessoas. Dentro da igreja. (Dimas)

O clima de medo estava espalhado:

Nós vínhamos aqui espiar se havia policiamento na porta do Sindicato. Nós vínhamos, mas só não podia parar ali, senão o cara te intimava. Aí passava direto, fazia a volta ali por baixo. Voltava, subia, passava em frente. E lá a polícia, com metralhadora, cachorro. Tem de tudo lá na porta do Sindicato. (Reinaldo)

A repressão policial foi muito dura para a gente. Era a época que a ROTA estava no auge. A ROTA, a tropa de choque. Era um momento muito difícil para a gente. Depois das dez horas, se você estava sozinho na rua, os caras vinham, reprimiam, batiam. E a tropa de choque, quando vinha, não queria saber se era trabalhador, se não era trabalhador, ou se estava indo ao banco. Eles vinham com o cacetete e todo mundo tinha que correr. Era uma repressão muito dura. E na época também era o governo Maluf, que dizia que bandido tinha que ir para a cadeia, que nós éramos vagabundos, que não queríamos trabalhar, que tínhamos serviço. (Wilson)

Não cheguei a ver pessoas sendo mortas, mas vi muitas pessoas sendo baleadas no movimento, pela polícia. A polícia vinha, reprimia. E aqui em São Bernardo mesmo chegou a ter até tanque de guerra. Eles traziam tanque de guerra e deixavam aqui. (Wilson) 


\subsubsection{A criatividade}

Muitas vezes, conforme relatam Adão e Wilson, os trabalhadores tinham que ser criativos na resistência e no enfrentamento. Eram métodos de mobilização e de protesto, cujo efeito estava relacionado ao impacto que poderiam ter, tanto sobre os trabalhadores como sobre a classe patronal.

Olha, Guilherme, é impressionante como esse pessoal tinha criatividade pra organizar. Lógico, eu já comentei com você em outros momentos, que a gente não tinha liberdade de fazer reunião, de distribuir panfletos nem coisa nenhuma. Já comentei como se dava esse processo. Mas na organização da greve a coisa era rapidinha. Se espalhava isso dentro de vários setores, e o pessoal tinha uma criatividade muito grande. Em cima das perseguições, foram obrigados a ter essa criatividade. Não sei se você conhece fábrica. Imagina o início de uma linha de produção. Como é que fica? Os caras têm uma facilidade muito grande de saber quem é que parou primeiro. Porque tem o cara que abastece a linha, tem o meio de linha, que é o meio de campo, e tem o final. Aonde congestionou mais peças, estão sabendo que é aquele que parou. Existia essa organização que quando parava, era como se desligasse o interruptor. Pá! Parou tudo de uma vez. Então não tinha cabeça. Os caras ficavam loucos. Por isso que até saiu o nome de uma greve, a vaca louca. O patrão, o chefão, ficava feito louco pra procurar. Eles davam aquelas investidas pra saber quem, de onde originou, quem parou primeiro, quem deu a idéia, essa coisa toda. Ninguém entregava ninguém, não. "Bom, parou. Se todo mundo parou, como é que eu vou trabalhar sozinho?” E assim ia. Achava super importante a maneira como aconteciam as coisas nesse processo de greve. (Adão)

E uma coisa, que não lembro se foi no ano de 80. A última grande greve mesmo foi em 80. Não sei se foi 79 ou 80. Saíram, ninguém sabe quem fez isso. A categoria estava um pouco oscilante. Então estava oscilando, vai para a greve, não vai, aquela coisa. $E$ aí de madrugada soltaram um panfleto nas portas das fábricas, dizendo assim: "Eu amo meu patrão". [risos] Aí o pessoal pegava aquela papel, olhava assim, e jogava fora. Amassava e ficava revoltado. Aquilo deu impulso na greve porque ninguém queria amar o patrão, todo mundo ficou revoltado [risos]. Aí surgiu a greve. Eu não estou lembrando se foi em 79 ou se foi em 80. Mas foi um fato que a gente lembra até hoje. Aquele comentário dentro da fábrica. E aí perguntavam: "Você ama seu patrão, né?”. [risos] Muito boa essa aí. (Wilson) 


\subsubsection{A amizade}

A greve era, enquanto movimento coletivo, uma ocasião de formação de laços de amizade. Esses laços estão ligados à formação e à prática política.

Até hoje, em função da AMA, do número de pessoas na AMA. Não foi só da Forjaria e da Mercedes que eu fiz amizades, mas em outras fábricas também. Devido a muitos seminários, muitos encontros, de levar jornal na porta das fábricas. Eu saía da Forjaria e ia para portas de outras fábricas. Teve uma vez que eu entrava das sete às cinco. Então eu saía de casa às cinco horas da manhã, vinha para o Sindicato e depois ia para a porta de outras fábricas para entregar a Tribuna Metalúrgica, junto com os diretores. Então nisso a gente pegou conhecimento. Então é essa amizade que a gente tem, esse conhecimento. O pessoal vem aqui, bate um papo, dá risada, conta casos do que aconteceu. Isso é muito gratificante, porque as pessoas vêm aqui na Associação, quer saber se a gente ainda está aqui, se encontra com a gente, vêm, aqui para sentar, dar risada. (Wilson)

Dentro da fábrica não dava pra conversar. De jeito nenhum. Tinham lá os encarregados e sub-encarregados. E tinha a questão do barulho. Pra você falar, era gritando um com o outro. Não tinha jeito. [...] Mas dentro da fábrica, naquela época, não tive condições de crescer coisa nenhuma. Foi depois dessa formação, que a gente passou por algumas palestras, por algumas formações, a gente começou a... como eu já te disse, mais dos anos 80 pra cá que a gente passou a conhecer a questão do capital versus trabalho, da organização no local de trabalho, e essa coisa toda foi mudando. Primeiro a gente começou a formar grupinho de amigos, e depois a gente até começou a saber como você vivia dentro da sociedade. (Adão)

\subsubsection{A solidariedade}

A solidariedade aparece principalmente ligada ao fundo de greve. Os trabalhadores que pararam de receber salário contaram com a ajuda desta entidade criada durante a greve. 
Em 79 e 80, eu estava na Borg. Inclusive viemos até pegar cesta básica. Não tinha dinheiro mais, que a firma não estava pagando. Começaram a doar cestas básicas. Eu cheguei a pegar uma cesta básica, na época. Faltaram as coisas para mim também. Faltou para muita gente, porque a firma bloqueou o salário. Não só da Borg, de várias firmas. Foi uma greve de 41 dias. Então nós vínhamos pegar a cesta básica, entrávamos na fila na Igreja da Matriz. (Dimas)

Na ocasião, acabou o dinheiro dos metalúrgicos, e eles estavam angariando dinheiro para dar para aquelas famílias mais necessitadas. Os metalúrgicos ganhavam um pouquinho mais, mas também gastavam bem mais. Então, quando a greve deu uma semana, quinze dias, o pessoal começou: "Vamos voltar a trabalhar. Não agüento! Na minha casa está faltando tudo!" A gente então fez uma campanha e começou a angariar geralmente mantimentos não perecíveis. E aí eu ia lá ajudar a pesar, ver quantos quilos, o tamanho da família, quantos elementos têm na família, quantas crianças, quantos adultos. Eu que fazia aquela fichinha, rápido, com a mão, e ajudava a pesar mantimentos e entregá-los. Nós tínhamos duas Kombis e íamos entregar nas casas das pessoas. (Reinaldo)

A solidariedade é fator de transformação social, de acordo com Wilson.

E os metalúrgicos, com essa garra e essa coragem, entram de cabeça e conseguem a começar a mudar nos anos 78 e 79. Não que antes não tivesse luta. Teve luta. Mas eles conseguiram, nesses anos mais fortes, começar a transformar o país. E a solidariedade das pessoas que eram oprimidas, começou a ajudar nessa questão. (Wilson)

E Adão, ocupando uma posição de chefia durante uma greve, demonstrou solidariedade a seus colegas de setor tirando proveito de sua posição para impedir as suas demissões.

Só que nessa greve de 85, depois que fecharam os acordos das reivindicações que a gente tinha... já tínhamos fechado durante a greve, primeiro que a firma ia dispensar bastante gente. Eles falaram: "Vamos ter que enxugar isso aqui, vamos ter que tirar bastante gente". Aí eles diziam assim: "Não existe um momento melhor do que esse. Todo suspeito vai ser demitido. Todos, todos. Sem exceção de nenhum”. Terminou a greve, começou a caça às bruxas. Já foi convidado um supervisor, o filha da puta já foi logo com uma lista de quinze nomes. Foram todos. Outro, acho que vinte nomes. Não me lembro o número exato. Foram todos. Aí, Guilherme, que eu fiquei bastante 
marcado nessa empresa. Me convocaram: "Adão, quantos vão lá do seu setor?" "Nenhum." "Como? Fulano é agitador, Sicrano também”. Eles apontaram cinco como agitadores do meu setor. Eu falei: "Engano seu. Vocês não viram eles participando de nada aqui. Desafio vocês: quem daqui viu?”. Nessas alturas do campeonato, nessa sala, tinha o Santino Carlos, que era o chefão lá dentro, tinha um japonês de nome Makoto, e o Sr. Moisés, que era o chefe de recursos humanos, já pra deixar tudo pronto. Quando eu fui com essa postura, que ninguém do meu setor iria: "Mas por quê? Se todos os outros setores têm, o seu tem. E nós vamos levantar nomes". Aí levantaram nomes, citou o Etevaldo, o Zé Bonfim, que está lá até hoje, o Abílio, a Maria Zilda e a Dona Lídia, como os cabeças. Falei: "Não, engano seu, nenhum desses participou. Eles ficaram na greve porque não dava pra ninguém furar a greve. Vocês sabem que quem tentasse passar entrava no porrete", "Não, mas tem gente que entrou, porque eles não entraram?", "Bom, essa pergunta não sei responder. Mas eles não são grevistas, não são agitadores, são pessoas excelentes. E no setor, como vocês têm aí no arquivo de vocês, eles estão requisitando mais cinco funcionários. Porque vocês vão mandar mais cinco? Aí eu vou ficar com uma defasagem de dez. Como eu vou atender a produção que vocês querem?”. Aí o filha da puta do japonês, radical pra caramba... inclusive, Guilherme, parece mentira, cara. Acredite se você quiser. Os caras tinham cacetetes em cima da mesa pra conversar com a gente. [...] O japonês bateu o cacetete debaixo da mesa: "Você não vai mandar?” "Não." "Então eu escolho!” "Makoto, você fica à vontade. Só que na medida que você está me tirando a autoridade do meu setor, você põe o meu nome em primeiro na lista. Você só vai fazer o que você quer no meu setor depois que você me tirar de lá, porque lá eu sou supervisor. Você é o meu superior, mas supervisor daquela área, quem responde por esse pessoal, sou eu. Pra tirar uma pessoa de lá, você põe o meu nome primeiro. Eu só pediria a vocês que respeitassem uma pessoa, que é um deficiente de audição, e é mudo." "Mediante essa sua postura aí, Adão, não sei." "Já falei, façam o que quiserem, com essa condição: põe meu nome aí.". Aí conversaram entre os três lá: "Faz o seguinte: nós vamos estudar esse caso" e já ligaram pra vir outro supervisor. Quando outro supervisor foi entrando e eu saindo, perguntou: "E aí? Menos dez lá?" "Depois te falo o número”. Ele estava trazendo uma lista de doze. Não é falar que eu sou bonzinho. Mas fui o único supervisor nessa greve de 85 que não deixou sair um dos subordinados. Não saíram. (Adão)

\subsubsection{Lula}

Lula, então presidente do Sindicato dos Metalúrgicos, entra como figura central nas greves. Para Adão, Lula foi quem o despertou para a política operária. 
E aí tentei procurar conhecer isso aí, aí que eu fiquei sabendo que o Lula - Luís Inácio Lula da Silva, mas todo mundo o conhecia por Lula - fez uma reunião com o pessoal que compunha a direção do Sindicato lá do $A B C$ que não era simpático à maneira como o Sindicato dos Metalúrgicos de São Paulo era conduzido. Essa equipe se reuniu. Nessa época o Djalma Bom era o presidente, ou diretor. Não me lembro exatamente o cargo que ele ocupava lá, era representante dos trabalhadores nesse Sindicato. O Lula sentou com ele e disse o seguinte: "Olha Djalma, nós precisamos montar uma chapa, conversar com o pessoal nas portas de fábrica, e com isso a gente ganha a direção desse Sindicato para a gente dar um rumo neste Sindicato. Que a gente ter um sindicato para ficar descontando mensalidade e não estar a serviço dos trabalhadores não faz sentido. Ou a gente muda esse Sindicato para ele ser um instrumento para os trabalhadores, ou vai deixar de existir, porque do jeito que está não tem utilidade nenhuma. Só tirar dinheiro das pessoas com essas histórias de assistência médica e colônia de férias e essas babaquices todas aí. Então isso não serve, não é o modelo de sindicato ideal. $O$ pessoal aqui do ABC está crescendo muito, muitas indústrias estão vindo, e nós precisamos ganhar este Sindicato e mudar os rumos dele". E aconteceram estas eleições, o Lula venceu, ficou sendo presidente desse Sindicato, e eu continuei aí observando, ouvindo o que acontecia dentro da empresa e acompanhando também o movimento dentro do Sindicato. (Adão)

Para Reinaldo, a greve está muito relacionada a Lula. Mas de maneira diferente de Adão, Lula foi para Reinaldo uma liderança a ser seguida, uma relação quase paternal.

Mas tinha assembléia toda semana. A cada dois dias. Ele não deixava a coisa esfriar. Marcava, convocava, e todos nós íamos para lá, na Vila Euclides. Dentro do campo. E o avião passava lá em cima, olhava de lá de cima. Colocavam holofotes. Faziam aquela pressão terrível. Mesmo assim, não evitavam. Toda a moçada, todas as firmas que estavam paradas iam lá na assembléia. Grandes e pequenas. Aí saía de alma lavada no fim da tarde. O chefe falou, já deu as explicações, já deu as orientações do que vai ser feito amanhã, do que vai ser feito depois de amanhã. Voltavam com todo o respeito, sem briga, sem encrenca. Nada de jogar pedra em vidraça. Não tinha nada disso. E cada qual ia para as suas casas, sem bagunça. E ele pedia também, quando ele fazia o discurso. Nada de bagunça, nada de provocação. Não mexa com nada de ninguém. E todos obedeciam. Ele tem o dom. Chamava e conversava. E todos entendiam bem. Ele fala um português claro. Ele é meio fanhoso como eu, mas ele fala um português limpo. Falava, e todos obedeciam. Ele era um líder. Ele nasceu... eu digo assim: o cara, quando nasceu para ser uma coisa, para onde ele for, aquilo vai e algum dia acontece. Ele era líder. Ele tinha uma liderança perante os metalúrgicos de São Bernardo que era coisa fora do comum. Fora de série mesmo. (Reinaldo) 


\subsubsection{As conquistas}

As greves dos metalúrgicos de São Bernardo e Diadema são abordadas por diversos pontos de vista nos depoimentos. Mas um significado é unanimemente dado às greves pelos entrevistados: as conquistas políticas por parte dos trabalhadores.

Todos os direitos que nós conquistamos com esses esquemas que estou te falando, não foi dado de graça. Foi na porrada, foi no grito, foi na paralisação, na mobilização, não foi fácil, não. Hoje você negocia até participação de lucro. Você nem sabia o que era lucro, hoje você faz discussão de participação de lucro, de resultados. Mas é fruto de lutas do passado. (Adão)

Eu não teria medo de errar nem um pouquinho afirmando pra você: o que temos de direitos conquistados na área trabalhista hoje, foi muita luta nossa. (Adão)

Eu acho que foi uma evolução. Acho que tudo, para melhorar, precisa de um sistema de evolução. Nada melhora só com diálogo, só com caneta. Você tem que criar um fato político. Se você não criar um fato político, não desenvolve nada. Então é isso que foi feito naquela época. Foram criados tantos fatos políticos que nós mobilizamos o Brasil todo. Então foi muito bom. (Dimas)

\subsubsection{O resgate da dignidade}

Os direitos conquistados, citados por Adão, aparecem para Laís Abramo (1999) tendo um significado simbólico, chamado por ela de "o resgate da dignidade". Afirma a autora: "Levantar a cabeça é romper a submissão e vencer a humilhação. Dizer eu estou aqui, eu existo e devo ser reconhecido como trabalhador e ser humano a partir da minha condição de trabalhador." (p. 273). E ainda:

A greve é o momento em que o trabalhador consegue recuperar a consciência da sua própria individualidade e da força do seu poder coletivo, em um mesmo processo. Em que ele se sente novamente gente e parte de 
uma categoria, representada por um sindicato, que consegue impor limites à opressão. Nisso está o resgate da dignidade. (ABRAMO, 1999, p. 275).

O resgate da dignidade aparece nos depoimentos colhidos para este trabalho.

E lógico que nossa questão mesmo era o banheiro. Nossas reuniões, nossas assembléias dentro da fábrica eram no banheiro. Então a gente ia para o banheiro, $e$ tinha um grupo lá. A gente debatia, voltava dentro do prazo na hora do almoço. Então a gente sentava e discutia. Até que a gente conquistou na fábrica o direito de fazer uma vez por mês uma assembléia com o pessoal. Então a gente teve essa conquista. A gente sentava. Era uma hora por mês, a gente parava toda a fábrica e ia fazer reunião com o pessoal. (Wilson)

Muita coisa mudou. O respeito aos trabalhadores, que não tinha. Antes das greves, a própria chefia batia no peito e falava: "Eu te mando embora a qualquer momento". Xingava. Teve caso que a gente soube de chefe que dava tapa na cara do operário. Após a greve isso foi mudando. $O$ trabalhador passou a ter direito, passou a conversar, passou a opinar. Passou a ter uma série de coisas que antes ele não era ouvido. Antes ele dava opinião para melhorar, e o pessoal não queria melhorar porque dizia que trabalhador não tinha que opinar, tinha que trabalhar. E o respeito ao trabalho, ao trabalhador, hoje, as empresas entendem. Elas procuraram melhorar seus quadros de RH, de chefia. Então, fazer um trabalho em grupo, fazendo cursos com chefias. O modo de tratar o trabalhador. Ele vivia mais na fábrica que em casa, então seria uma mudança necessária. Esse respeito foi uma grande mudança que houve com os trabalhadores. (Wilson)

Eu acho o seguinte: depois das greves, o trabalhador ficou mais firme no chão da fábrica. Por tudo que nós passamos, quando voltamos para o chão da fábrica, voltamos com mais confiança. Tanto é que criamos as comissões de fábrica, o comitê sindical de empresa. Acho que foi um estímulo para melhora. Enquanto não tiver um movimento mais revolucionário, as coisas não melhoram não. Acho que esses movimentos de 78, 79 e 80, indiretamente foram revolucionários. Greve. Mas tem que criar um fato político. Quando o pessoal voltou para o chão da fábrica, voltou mais confiante. $O$ pessoal ganha mais confiança. Confia mais em si e no conjunto dos trabalhadores. (Dimas)

Mudou muito. A greve serviu de parâmetro para muita coisa. O respeito, a maneira de tratar a chefia dentro das fábricas. O trabalhador sindicalizado começou a ter muito mais respeito depois das greves. Foi uma coisa que serviu como uma lição. Os direitos começaram a aparecer. Você já não precisava requisitar tanta coisa. 
Proteção de máquina, proteção em uma portaria. A abordagem à gente. A revista passou a ser mais maneirada na entrada. Na entrada não. Mas na saída todo mundo era revistado. Começou a haver mais respeito. A greve serve, tem um significado bom. $O$ resultado é sempre bom. Não parece, porque é um nome feio. Você para ali, quebra uma coisa aqui, faz sabotagem. Vai ter sabotagem, vai quebrar uma máquina, vai pôr uma bomba. Não tem nada disso. É balela. Não existe nada disso. (Reinaldo)

As lembranças que os metalúrgicos do $\mathrm{ABC}$ têm das greves da categoria estão associadas a múltiplos fatores, não necessariamente desconexos. O momento político e social do Brasil na época estava relacionado ao fim do regime ditatorial, e as greves estavam conectadas a esse contexto.

Permanece até hoje um orgulho de ter feito parte deste movimento, dada a importância dele. Como disse Wilson: Eu tenho uma grande admiração pelos metalúrgicos do $A B C$. E faço parte dessa história. 


\section{MEMÓRIA COLETIVA/MEMÓRIA DA AÇÃO}

\subsection{Memória das testemunhas}

Nos depoimentos ${ }^{9}$, uma série de acontecimentos marcantes para todos os metalúrgicos do ABC aparece de uma forma ou de outra, que são as assembleias no Estádio da Vila Euclides. Vejamos como cada entrevistado relata a assembleia:

O episódio que mais marcou para mim foi na Vila Euclides, na greve de 80. Como eu te falei, foi quando eu vi aquele helicóptero passar, com o exército. Os caras de fora, dos dois lados, com metralhadora. Isso chocou demais, chocou pra caramba. (Dimas)

Das greves de 78, 79 e 80, eu só tenho a acrescentar o seguinte: Houve muita covardia por parte do governador do estado, que na época era o Paulo Maluf. E ao mesmo tempo temos que agradecer o prefeito daqui, que cedeu o Paço Municipal. Que é o Tito Costa. E auxiliou a gente em tudo. (Dimas)

Nós enchíamos aquele campo, na Vila Euclides. O Lula que marcava. "Amanhã, todo pessoal, às dez horas aqui! Tal dia, duas horas da tarde!”. Todo mundo ia. De todas as firmas que estavam paradas. Iam lá conversar com ele. Ele subia naquele palanque improvisado. Só que havia fiscais, uns guardas que ficavam dando proteção a ele. Tinha um corredor para ele passar. Quando ele ia entrar no palanque, tinha uns elementos de confiança. Só ficava lá dentro o pessoal de confiança. Eram como se fossem uns guardas. Ele tinha proteção dos metalúrgicos. Era uma boa proteção. (Reinaldo)

Mas tinha assembléia toda semana. A cada dois dias. Ele não deixava a coisa esfriar. Marcava, convocava, e todos nós íamos para lá, na Vila Euclides. Dentro do campo. E o avião passava lá em cima, olhava de lá de cima. Colocavam holofotes. Faziam aquela pressão terrível. Mesmo assim, não evitavam. Toda a moçada, todas as firmas que estavam paradas iam lá na assembléia. Grandes e pequenas. Aí saía de alma lavada no fim da tarde. O chefe falou, já deu as explicações, já deu as orientações do

\footnotetext{
${ }^{9}$ Rafael é o único que não menciona as assembleias. No entanto, seria interessante saber o que ele sabe das assembleias no Estádio da Vila Euclides, mesmo sem que ele tenha participado delas, pois ele faz parte do mesmo grupo (metalúrgicos do $\mathrm{ABC}$ ) que construiu uma memória coletivamente.
} 
que vai ser feito amanhã, do que vai ser feito depois de amanhã. Voltavam com todo o respeito, sem briga, sem encrenca. Nada de jogar pedra em vidraça. Não tinha nada disso. E cada qual ia para as suas casas, sem bagunça. E ele pedia também, quando ele fazia o discurso. Nada de bagunça, nada de provocação. Não mexa com nada de ninguém. E todos obedeciam. (Reinaldo)

E numa manifestação nós estávamos na Vila Euclides, ainda quando os militares... não me lembro exatamente se foi em 79... a coisa ficou feia, rapaz. Olha! A ordem lá de cima era para que não acontecesse essa manifestação. E os diretores do Sindicato e todos os trabalhadores entendiam que tinha que acontecer. Aí fomos para a Vila Euclides. Aquilo ficou de um jeito que não dava nem para andar. Começaram as falas. Daí a pouco chegou a tropa aqui de São Paulo. O Maluf estava no poder na época, era governador biônico. E mandou a tropa toda daqui para lá para descer o pau, nos dispersar, descer o pau. Tinha cachorro, cavalo, e muitos caras à paisana no meio para tentar agarrar um aqui e agarrar outro ali. Além do pessoal com equipamentos oficiais dos poderosos, tinha também o pessoal que estava disfarçado. Esse dia houve um derramamento de sangue em São Bernardo que eu achei que iria marcar legal a bandeira do Brasil. Um derramamento de sangue dos maiores que a gente poderia imaginar. Mas tivemos a felicidade de um cidadão de nome Tito Costa, que era o prefeito de São Bernardo na época, ele subiu na escada, pegou um megafone [não tinha carro de som naquela época]. Subiu na escada e ordenou que o comandante daquela tropa retirasse aquela tropa dali. Ali estava acontecendo uma manifestação de várias pessoas, tinha muita criança, mães, e não era justo que as coisas andassem daquele jeito. E colocou a seguinte fala: "Olha, na cidade de São Bernardo, eu sou a autoridade máxima porque eu sou o prefeito, e eu não solicitei a ajuda de São Paulo. Portanto eu sugiro que o comandante dessa tropa se retire imediatamente ou ele, junto com quem mandou ele para cá, se responsabilizará por tudo. E gostaria que a imprensa registrasse isso, se é que tem alguma imprensa por aqui, que eu, Tito Costa, prefeito de São Bernardo, estou ordenando que a tropa vinda de São Paulo, se retire para evitar maiores problemas. Caso contrário, o comandante, junto com o governo de São Paulo, responderá pelos acontecimentos”. E aí ele fez o toque de recolhimento, retirou a tropa. Porque a gente também não ia deixar barato, já tinha combinado com o pessoal, que a gente não ia provocar, mas não ia aceitar provocação. Se era para quebrar o pau a gente ia quebrar mesmo. Já tinha alguns esquemas para entrar no enfrentamento. A gente sabia que não era fácil, ia ocorrer um grande derramamento de sangue se não houvesse essa intervenção do então prefeito de São Bernardo. Se foi bom ou foi ruim são outros quinhentos, mas se muitas vidas se salvaram, se deve à posição desse cara que acho que agiu na hora certa. No meu ponto de vista, né? De repente, não está certo. Mas no meu ponto de vista ele evitou que muitas mortes acontecessem. Com certeza ia morrer gente inocente. Não ia dar para separar quem é quem. Ia ser uma guerra mesmo. Com isso aí a tropa saiu. A gente conseguiu continuar e terminar o ato. (Adão) 
Meu horário de trabalhar era às seis horas. Saía de casa às cinco horas e ia trabalhar. Então, na greve, a gente parava as máquinas. De greve! A gente saía, todo mundo, e ia para a assembléia, e ficava até meio-dia. Meio-dia a gente ia para casa almoçar, e depois voltava para a assembléia. Depois da assembléia ia para a igreja. Aí era aquele tumulto de gente. Tinha polícia militar, polícia civil, metendo o cacete. De noite ia embora para casa, e no outro dia era a mesma coisa. (Nelson)

Fazia piquete, porque tem muitos pelegos, que querem entrar para trabalhar. A gente tirava os pelegos de dentro do ônibus para ninguém trabalhar. E ninguém trabalhava. E aí voltava para a assembléia. Passavam aqueles aviões por cima, com aquelas metralhadoras, e o Lula falando. O Lula falando e aquele barulho: pó, pó pó. E aí ia para casa. Voltava, e ia para a assembléia. Ficava até às cinco horas, e depois voltava para casa. "Hoje encerrou”. No outro dia, a mesma luta. Sentava em cima da máquina. Eu era preparador de peça. Com a lima, [imita o som de alguma coisa que não sei bem o que é] e falava: "Hoje ninguém trabalha!". E começava a mesma luta. Mesma luta, mesma luta. E da última vez fizemos às três. Da uma às três. E polícia civil e militar descendo o cacete, e corre, corre, corre. Aqueles brucutus soltavam aquela fumaça, aquele gás, e ficavam todos chorando. Chorando sem querer. E a gente ia para casa. (Nelson)

As primeiras assembléias que eu vim a participar foram no Sindicato. E pelo que eu sei da diretoria do Sindicato, eles tinham que mandar a pauta da reunião para o DOPS, qual seria o discurso, e vinha a polícia acompanhar a assembléia. E muitas vezes pessoas que se alteravam, falavam mal do governo, já saíam presas de dentro do Sindicato. Ou eles saíam lá fora, já estavam marcados, e o camburão já estava esperando para prendê-lo. E a maioria do pessoal então pedia para a pessoa ser branda. (Wilson)

E tinha também as reuniões secretas. Muitas reuniões secretas para ver qual era o perfil, como a gente ia se portar, como a gente ia se defender. (Wilson)

Depois foi para a Vila Euclides. Na época o prefeito aqui era o Tito Costa. Aí começaram a trabalhar na Vila Euclides. Na Vila Euclides foi proibido. Cortaram a luz, cortaram o som, cortaram tudo, o helicóptero voando por cima. Depois foi para a Praça no Paço Municipal. No Paço Municipal a polícia cercou também. E depois viemos aqui para a Igreja da Matriz. Aí na Matriz houve bombas dentro da igreja, pessoas machucadas, ensangüentadas. Mas o pessoal foi resistente. Como eu disse no início: eram 24 diretores no Sindicato. Mas tinha uma grande massa que queria mudança, e isso ajudou muito. (Wilson)

E uma coisa que a gente admira no companheiro Lula e na sua diretoria é que não foram omissos em nenhum momento. Eles assumiram a greve. Como liderança eles 
deram o exemplo de unidade, de vir na frente e trabalhar, assumindo totalmente a greve. O apoio, vinham e conversavam com a gente, davam orientação, como a gente poderia se comportar. Nós estávamos de greve, então não era para destruir isso, destruir aquilo, jogar pedra. Alguns no meio a gente sabia que eram policiais infiltrados, e eles jogavam pedras nas vitrines das lojas. E aí a polícia vinha para dispersar tudo. Então teve passeata de mulheres. As mulheres vinham fazendo panelaço. Então as assembléias, as greves, as passeatas, tiveram uma influência muito grande na sociedade. E aí a gente começou também a montar os blocos. De um lado e de outro você vai ficar tomando conta, porque havia muita garrafa de pinga. Muitas vezes o cara terminava de tomar a garrafa de pinga e queria jogar a garrafa. Então já tinha um pessoal para segurar e ele não jogava. Porque o dono da loja, o pessoal que estava ali não tinha nada a ver com a greve. Era uma greve contra a empresa onde a gente trabalhava. E não contra o lojista, ou contra quem quer que seja. Então isso a gente conseguia controlar. E com o tempo a polícia começou a ser mais branda com a gente porque começou a entender nosso lado. (Wilson)

Há alguns elementos em comum nos relatos: a ação truculenta e violenta da polícia, chegando em helicópteros; o governador do Estado à época, Paulo Maluf, que enviou a polícia para conter a manifestação; o prefeito de São Bernardo do Campo, Tito Costa, que interveio na ação da polícia; e Lula em cima do palanque proferindo seu discurso. Esses são episódios contados e recontados pelos metalúrgicos do ABC. A imprensa escrita e os meios tele ou rádio-difusores divulgaram, de alguma forma, a manifestação. Há registros em filmes e livros sobre ela. Sua consolidação na memória coletiva é forte.

"Contudo", diz Halbwachs (2006), "se a memória coletiva tira sua força e sua duração por ter como base um conjunto de pessoas, são os indivíduos que lembram, enquanto integrantes do grupo. Dessa massa de lembranças comuns, umas apoiadas nas outras, não são as mesmas que aparecerão com maior intensidade a cada um deles." (p. 69). Complementa Bosi (1994): "Ele (o indivíduo) é o memorizador e das camadas do passado a que tem acesso pode reter objetos que são, para ele, e só para ele, significativos dentro de um tesouro comum.” (p. 411). Notamos que cada depoimento sobre as assembleias na Vila Euclides tem um foco, uma dramatização, uma intensidade, uma coloração diferente.

Dimas lembra mais da violência da polícia; ver os helicópteros sobrevoando o Estádio com policiais o chocou pra caramba. Nelson também tem marcada em sua lembrança a violência policial, citando o gás lacrimogênio. Reinaldo chega a citar aviões passando por cima da assembleia. 
Dimas diz que o prefeito Tito Costa ajudou muito os metalúrgicos, e este é citado também por Wilson. Mas é Adão quem conta com detalhes o ato do prefeito que impediu um derramamento de sangue.

Wilson não se detém muito às assembleias da Vila Euclides, e menciona os outros espaços onde aconteceram as assembleias. Ele narra mais a importância de Lula e do resto da diretoria do Sindicato na orientação de como agir nas manifestações ${ }^{10}$.

Lula é também mencionado por Nelson, cujo som do discurso era abafado pelo barulho dos helicópteros. Já Reinaldo focaliza nas assembleias a figura de Lula, que marcava as reuniões, ordenava que ninguém quebrasse nada, e fazia discursos que deixavam o pessoal de alma lavada.

De todos esses trechos, nos chama atenção a forma como Wilson lembra das greves em um entrelaçamento, na sua narrativa, entre seu testemunho individual e a construção coletiva da memória. No trecho transcrito anteriormente, da entrevista de Wilson, fica claro como ele distingue o $e u$, usado para os momentos que descrevem suas sensações e o localizam como indivíduo, do nós, que o coloca como parte de uma coletividade.

Em seu depoimento, Wilson nos dá um exemplo da construção coletiva da memória. Ao afirmar que as primeiras assembléias que eu vim a participar foram no Sindicato, fica clara uma marcação no tempo de seu envolvimento com o grupo grevista. Ao mencionar as reuniões secretas, necessárias ao movimento devido à repressão policial, ele já se inclui como parte do grupo, dizendo que estas serviam para decidir como a gente ia se portar, como $\underline{a}$ gente ia se defender. Ele ainda distingue a diretoria do Sindicato, liderada por Lula, que dava apoio à base, onde ele se localizava.

Em outro momento, Wilson deixa claro como sabe localizar-se no grupo do qual faz parte: Olha, eu tenho uma grande admiração pelos metalúrgicos do ABC. E faço parte dessa história.

A construção coletiva da memória das greves passa pelo testemunho dos fatos e pela troca de experiências e informações. Wilson nos conta, em uma mesma passagem, fatos que ele testemunhou - as passeatas, o panelaço, os diretores orientando os grevistas sobre comportamento na greve - e fatos que ele possa ter testemunhado ou até mesmo ter sido informado sobre eles. Ele viu as pessoas sendo presas na saída do Sindicato? Ele viu manifestantes ameaçando jogar as garrafas de pinga nas vitrines? Ninguém duvida que isso

\footnotetext{
${ }^{10}$ Adão também menciona a preparação para a ação na greve, mas em outros momentos.
} 
tenha acontecido. Mas é interessante notar, em sua fala, a construção coletiva da memória desses fatos.

Há algumas narrativas de Adão de fatos que ele não testemunhou, mas que foram importantes para ele. Duas delas referem-se a Lula: a conversa de Lula com Djalma Bom sobre a reformulação do Sindicato, e a recusa de Lula em ser cooptado pelos patrões. É possível identificar nessas ocasiões, mais que uma memória de sua participação efetiva ou testemunhal, uma construção coletiva da memória.

Há informações, que sabendo das péssimas condições de vida que o Lula tinha, a Volks comprou um apartamento, mobiliou, pôs um carro [um Fusca, parece] na garagem. Mandou representante e falou: "Lula, isso aqui é seu. Pra você não se meter mais nesse negócio aí. Deixa agora pros outros presidentes”. [...] Eu não presenciei. Isso foi o que eu ouvi. (Adão)

Como diz Halbwachs (2006), não é preciso haver testemunhado um fato para que este faça parte do repertório do memorialista. E segundo Mahfoud e Schmidt (1993), a elaboração da experiência daquele que narra os fatos "pode ser entendida como um processo de diálogo entre diferentes pontos de vista atuais e passados que, de alguma forma, estão presentes para o indivíduo.” (p. 295). A consolidação de uma memória coletiva passa pela narração dos fatos, postos em confronto pelos diferentes pontos de vista.

\subsection{Memória da ação}

Pudemos contrastar alguns pontos de vista sobre um grande acontecimento público, como foram as assembleias no Estádio da Vila Euclides, onde um grande número de metalúrgicos reunia-se para escutar os discursos de Lula e outros diretores sindicais. Nessas assembleias, talvez o máximo que cada indivíduo pudesse fazer fosse votar contra ou a favor de alguma proposta, levantando a mão.

Chama a atenção, por outro lado, a vivacidade com que são narrados alguns episódios que têm o próprio depoente como protagonista. São lembranças da própria "ação", que estão relacionadas a momentos em que houve participação efetiva do entrevistado. A greve geral, 
ou uma grande assembleia, impõe uma limitação de ação à grande massa de grevistas. Mas momentos de resistência e de greve na fábrica, momentos de prestar solidariedade aos companheiros, momentos de enfrentamento às chefias, são momentos que exigem do grevista uma "iniciativa". Agir, para Arendt (2005), significa tomar iniciativa. "É de natureza do início que se comesse algo novo, algo que não pode ser previsto a partir de coisa alguma que tenha ocorrido antes. Este cunho de surpreendente imprevisibilidade é inerente a todo início e a toda origem.” (p. 190-191). A ação, enquanto iniciativa, corresponde ao fato do nascimento. Cada início é como se fosse um segundo nascimento.

Vejamos então de que fatos se lembram os depoentes que agiram.

\subsubsection{Greve na fábrica}

O movimento grevista na fábrica é aquele que permite a cada trabalhador um papel importante de ação, pois é no chão da fábrica que ele conhece seu cotidiano. Vejamos nos trechos a seguir como eles sentem certa familiaridade com o lugar e com as pessoas, tornando a ação mais fácil.

Aí eu cheguei no supervisor de produção e falei: "Nós vamos fazer isso porque está ruim. O senhor almoça lá, o senhor percebe. O senhor janta lá, o senhor percebe”. Ele: "Até acho que vocês devem fazer, mas eu não vou fazer. Nem eu nem os outros supervisores, senão fica mal para nós". "Então vocês aguardem, que nós vamos fazer”. Paramos tudo! Ficamos uma semana. E depois dessa semana, eles trocaram o restaurante, por um muito bom. Aí todo mundo gostou. (Dimas)

Numa outra greve, nessa unidade mesmo, uma greve que durou vinte e poucos dias, também com a presença da polícia, que chegava pra arrepiar, eu fiquei do lado de dentro da firma. Eu já havia sido promovido pra supervisor. A empresa percebeu o poder de fogo que a gente tinha, e a capacidade profissional. E como eu havia sido eleito pela CIPA, eu tinha estabilidade. E eles sabiam que o Sindicato não ia abrir mão pra eles me mandarem embora e me pagarem os meses que eu tinha direito de estabilidade. Eu tinha uns seis meses de mandato, eram dois anos de estabilidade, então eu tinha um ano e meio pela frente de salário garantido. E mesmo assim, eu não ia aceitar de forma nenhuma. Mesmo se o Sindicato acordasse com a empresa pra me mandar embora e me pagar os direitos previstos por lei, me pagar esses meses de 
estabilidade, jamais eu aceitaria. Inclusive eu já tinha até me programado pra uma greve de fome na porta da fábrica. Se isso viesse a acontecer eu iria fazer. Não ia abrir mão. Enquanto não fosse modificado, eu não voltaria atrás. Eu já tinha até conversado com algumas pessoas mais próximas: "Se isso acontecer, pode ser o meu fim, porque eu vou ficar na porta da fábrica e não vou sair, não. Só saio morto”. Só que o que aconteceu? Me promoveram pra supervisor. E um dos critérios pra supervisor é não participar da greve. E a nossa orientação mesmo, como funcionário, é de não confiar em supervisor. Não dá pra confiar mesmo. Supervisor é bicho safado. Inclusive eu aceitei o cargo de supervisão estrategicamente. Nessa greve aí, vou te contar, eu já estava como supervisor. Aconteceu essa greve, a firma mandou uma infinidade de gente embora. No décimo primeiro dia em diante, começou. A gente chegava de manhã e lá estava a listona dos caras que tinham que assinar o aviso prévio. Dispensados por justa causa ou coisa parecida. E eu, do lado de dentro. Nessa aí, eu comecei a participar das reuniões internas, que a direção da empresa fazia junto com representantes da polícia. Eu vou citar nomes, senão fica muito vazio. Eu poderia falar que alguém da manutenção, ou alguém da segurança. Eu prefiro citar nomes, porque eu não tenho medo de fazer isso. Os caras estão vivos, e se vierem me perguntar, eu vou falar: "Quer negar o que você falou, o que você fez?". Então tinha o supervisor da manutenção, de nome Ivani. Ele se prontificou a ir à serra da carpintaria, e cortar os sarrafos pra polícia entrar que nem uns loucos. Os policiais falaram: "Está inflamado aí fora, o pessoal está pra invadir a qualquer hora, e a gente não sabe se vai agüentar isso sozinho. Então o que vocês vão fazer? Se tiver bastante pedaços de madeira aí, vamos colocar em alguns pontos, e na hora da invasão, todos que estão aqui pegam esses sarrafos e descem o pau. Vocês batem despreocupados. Se quebrar o osso, ou se matar, não são vocês, somos nós da polícia que fizemos". Aí esse Ivani falou: "Não temos essas madeiras, mas eu vou sarrafear as tábuas lá, vou cortar”. Ele sarrafeou um monte de pedaços de madeira. Sarrafos de madeiras de cinco por dois e meio, por um e vinte mais ou menos de comprimento, que era a medida certa pra descer o pau. E colocou em três pontos estratégicos, onde poderia acontecer a chegada do pessoal. Então já fomos orientados: "Se você ver que vão invadir por lá, já tem as madeiras ali. Mete o pau! Qualquer coisa, foi a polícia que fez". Aí, Guilherme, que eu achei que foi muito importante meu papel em estar lá dentro. $O$ que eu fazia? Se essa reunião acontecia na parte da manhã, no primeiro período - e normalmente tinham duas reuniões por dia, uma de manhã e uma à tarde, pra fazer a avaliação e a programação de quais estratégias seriam montadas. E o chefe da segurança, Sr. Lázaro, ficou com a incumbência de articular as pessoas pra fazer espionagem lá fora. O Ivani assumiu o papel de cortar as madeiras, e o Sr. Lázaro assumiu o papel de articular a espionagem. Quando eu saí pra almoçar, eu já tinha aquelas pessoas de alta confiança que estavam na greve. Eu chegava lá e falava: "Fulano," - um deles era o Etevaldo, que não trabalha lá mais, o outro era o Abílio "em tal lugar tem tantos sarrafos. Se nós entrarmos, é pra descer o pau em vocês. Se nós matarmos um de vocês, ou quebrarmos os ossos de um de vocês, a polícia vai assumir. Então a primeira coisa..." Só que aí, Guilherme, você tem que saber com quem você está falando. Não podia falar pra qualquer tranqueira senão 
você se ferrava todinho. Era meu caso que estava lá dentro. Eu disse: "Vocês já sabem o que fazer. Se vocês entrarem pelo portão tal, os sarrafos estão em tal lugar. Primeiro lugar que vocês têm que dominar é esse, pra não deixar que a gente pegue. Porque eu não vou poder me afastar”. Eram trinta e poucas pessoas de chefia que estavam ali dentro. Eu não podia me recusar sozinho. Pelo menos pegar na madeira eu ia ter que pegar. Muito embora eu já tinha na cabeça em quem eu bateria. Não ia bater em peão. Acidentalmente, eu já sabia em quem eu bateria. [risos] Já que podia matar ou quebrar um, que não teria problema, eu já sabia perfeitamente em quem eu ia bater. E foi muito legal, cara! Porque aconteceu. Aconteceu a invasão. O pessoal quebrou o portão. No que entraram, foram todos em cima daqueles blocos de madeira. [risos] Aqueles sarrafos que seriam pra nós usarmos, serviram de arma pra eles. Aí não deu pra polícia confrontar, não. Recuou todo mundo. Aí foi o dia que apedrejaram, deu um rebuliço mais ou menos. Aí eles ficaram preocupados depois em saber como é que o pessoal sabia que tinha madeira ali. Todo mundo ficou na sua. E a partir desse ponto, já começaram a negociar. Isso aí foi de manhã cedo, que teve a reunião. Eu passei essa informação. Na parte da tarde desse mesmo dia não houve nada. No dia seguinte é que houve a invasão de manhã. Aí a gente não teve nem como fazer essa reunião. O pau comeu. Na parte da tarde a gente já foi fazer a avaliação. E aí que saiu o questionamento: como eles puderam saber dessas madeiras? Ninguém sabia. Lá, quando eu passei as informações, eles também já tinham os contatos deles. (Adão)

Dimas avalia que a greve na fábrica é o que forma o militante operário.

A experiência da gente é essa. A gente fala das greves da categoria, das greves gerais de 78, 79 e 80, mas a experiência da gente começa dentro da firma, dentro do chão de fábrica. Essa que é a experiência que a gente tem. É lá que a gente define, é lá que a gente faz. Quando você sai para fora, você sai junto, e já sai sabendo fazer. Já sai preparado. (Dimas)

\subsubsection{Enfrentamento à chefia e à polícia}

Alguns trechos mostram como o grevista usava sua inteligência para se rebelar contra a repressão policial e patronal. 
O que as firmas faziam? Começaram a contratar os policiais pra prestar serviço fora do expediente de trabalho. [...] E aí até cito um exemplo, na greve de 82, onde eu trabalhei. Ficaram lá quatro policiais uns quinze dias. Sempre os mesmos, nos nossos horários. Eles faziam bico lá, e trabalhavam na Ford, e da Ford já vinham direto. [...] Quando ia ter um conflito, eles queriam mandar uma turma nossa embora. A gente não aceitou, e aqueles quatro policiais que estavam ali não davam nem pro cheiro. Foi quando eles mesmos solicitaram reforço. Daí a pouco chegaram uns dez ou quinze camburões. [...] Três camburões entraram nas dependências, já abriram as portas traseiras, e ele procurando o pessoal pra prender. E prendeu. Prendeu cinco. Foi interessante isso, rapaz, um ponto muito interessante nessa unidade. Quando esses cinco companheiros foram presos, o pessoal circulou as viaturas. [...] Sabe o que acontece? Isso aí, rapaz, é até bonito, que foram as mulheres que fizeram isso. Elas chegaram na lateral do carro e levantaram o carro. O pneu girava em falso. [risos] Foi muito legal isso! Não consigo esquecer, o filme ficou gravado na minha mente. [...] Aí, o motorista engrossou: "Quem são vocês pra me dar ordem?" "Nós estamos pedindo. Você não quer descer? Então você vai ficar aí até a hora que você sentir vontade. Nós não estamos cansados de segurar o carro. Pode roçar motor, pode fazer o que você quiser”. Com muito custo, desceu. O cara desceu. Desceram dois de um lado, dois de outro. Foi a conta de o cara descer, o pessoal fechou a porta do carro de uma vez, e a gente isolou a polícia do carro. Aí falamos: "Agora nós vamos negociar". "Mas negociar o quê? Vocês têm que negociar com a empresa!" "Não. Cinco companheiros estão aí dentro. Nenhum vai preso. Vocês não têm dignidade pra levar nosso pessoal preso. Vocês já mataram uma infinidade. Esses cinco aí vocês não vão matar, não. Se forem matar, vão ter que matar o resto." Eram 1.200 pessoas. "Pode mandar vir transporte da companhia de vocês pra levar todos nós, porque os cinco só não vão. Ou vocês liberam esses cinco, ou levam todo mundo”. Aí foi aquele bafafá danado. Chegou o mais forte deles e acabou negociando. Aí chegou a imprensa. Aí a coisa já começou a complicar. De repente ele: "Então vamos fazer o seguinte: eu vou abrir a porta traseira”, eles não falam chiqueirinho, o papo deles lá é outro, "os cinco infratores vão descer, e juntos, vocês vão tirar uma comissão pra responder pra nós o que vai rolar daqui pra frente”. Tudo bem. Aí já desceram os cinco. Aí não fomos pra dentro do carro, fomos pra uma sala negociar. (Adão)

O pessoal se mobilizava bem e vinha para cá. A gente vinha andando, participava de tudo. Tudo que você pensar a gente participava. Enfrentava também a "boca". Corria às vezes, ia para cima também. O negócio era pauleira. Era pauleira mesmo. (Dimas) 


\subsubsection{Solidariedade: 0 fundo de greve}

Para alguns trabalhadores foi marcante a participação no fundo de greve, que ajudava os grevistas sem salário sustentarem a si próprios e as suas famílias.

De manhã eu levava duas garrafas térmicas de café para o pessoal tomar. Na ocasião, acabou o dinheiro dos metalúrgicos, e eles estavam angariando dinheiro para dar para aquelas famílias mais necessitadas. Os metalúrgicos ganhavam um pouquinho mais, mas também gastavam bem mais. Então, quando a greve deu uma semana, quinze dias, o pessoal começou: "Vamos voltar a trabalhar. Não agüento! Na minha casa está faltando tudo!" A gente então fez uma campanha e começou a angariar geralmente mantimentos não perecíveis. E aí eu ia lá ajudar a pesar, ver quantos quilos, o tamanho da família, quantos elementos têm na família, quantas crianças, quantos adultos. Eu que fazia aquela fichinha, rápido, com a mão, e ajudava a pesar mantimentos e entregá-los. Nós tínhamos duas Kombis e íamos entregar nas casas das pessoas. (Reinaldo)

E eu sou um dos fundadores do fundo de greve. Lá na [Igreja da] Matriz a gente separava mercadoria para o pessoal. E até hoje eu sou sócio do fundo de greve. Então isso para a gente é uma coisa que não tem o que pague. Porque a gente faz parte dessa história. (Wilson)

\subsubsection{Resistência na fábrica}

A resistência às condições de trabalho ruins e ao despotismo patronal aparece nos depoimentos de forma mais ou menos organizada. Adão conta como tirava proveito de uma posição de membro da CIPA (Comissão Interna de Prevenção de Acidentes) para reivindicar a garantia de direitos. Wilson fala como a organização coletiva driblava a repressão dentro da fábrica. Já Nelson, mesmo sendo membro da CIPA, conta de uma ação mais isolada da organização coletiva. 
No bebedouro, tinha dia que saía uma larvazinha na minha água. Isso me marcou muito pelo seguinte: os colegas meus foram tomar água, não sentiram isso na boca, o outro percebeu num copo... Não era copo descartável como hoje em dia tem, naquela época cada um tinha seu copo. Acionou o botão pra tirar água, veio um monte de bichinho dentro da água. Como eu era da CIPA, ele veio reclamar isso pra mim. Levei essa reclamação pro gerente. (Adão)

Fez um sinal que não estava nem aí, o Sr. Lázaro. Falei: "Não posso deixar isso continuar". Fui nos recursos humanos e falei com esse Moisés. Ele falou: "Olha, eu cuido aqui de papelada. Como é que eu vou me envolver com isso aí?". Falei: "Porra, mas tá danado. O chefe de segurança não diz nada. O chefe de recursos humanos não diz nada. A peãozada já quer resolver”. Aí pulei todas as instâncias. Fui direto pro presidente da empresa. O falecido Leonel, que na época era um nó cego do caramba. Autoritário que era o diabo. "Sr. Leonel, dá licença”. Ele abaixou os óculos assim: "O que você quer?" "Vim mostrar pro senhor a água que o pessoal está bebendo na fábrica”. (Adão)

E essas pessoas eram as pessoas que a gente reunia, vinham para o Sindicato, discutíamos e debatíamos com eles e eles eram os formadores de opinião. Então a gente tinha toda essa questão. E lógico que nossa questão mesmo era o banheiro. Nossas reuniões, nossas assembléias dentro da fábrica eram no banheiro. Então a gente ia para o banheiro, e tinha um grupo lá. A gente debatia, voltava dentro do prazo na hora do almoço. Então a gente sentava e discutia. (Wilson)

A segurança não era muito boa. Eu estava ali de auxiliar de "cipeiro", quando tinha alguma irregularidade... eu trabalhava embaixo, a comissão era em cima. Quando a máquina estava soltando alguma irregular, descia alguém: "China, vem aqui. Aquela máquina está assim, assim, assado”. O titular era o Geraldo, eu era auxiliar. $O$ Geraldo era da usinagem. Aí eu anotava tudo, chegava na chefia: "Tal máquina está assim, assim, assado". "Está bem, pode continuar trabalhando". Mandavam a chefia lá e ele parava a máquina. Aí ficava de quinze dias a um mês parada. Quando eles não paravam a máquina, eu ia falar com o Geraldo: "A máquina está assim e assim". O Geraldo ia lá e mandava parar a máquina. Tinha uma máquina lá que tinha uma serra. Chegavam os caras lá, pegavam a serra, iam colocar. E os caras só reclamando que se acidentavam. Pedi para colocarem outra peça. A serra é muito grande, tem que encaixar. Aí colocaram uma [inaudível] [peça], descia [imita o barulho da serra descendo], e aí o cara tinha que ter força para encaixar. Aí os caras falavam: "Muito bem, China! Você está trabalhando legal. Muitos caras se machucaram”. Muitas coisas eu resolvi. [...] Eu subia lá. Meu serviço era produção. Quatro pessoas dependiam do meu serviço. Eu fazia "pá, pá, pá”, terminava logo e ficava tranqüilo. Aí eu pegava a prancheta, subia, e os caras: "China, vem aqui. Tem uma máquina assim e assim". O feitor me tirou desse serviço: "Você está andando muito!", "Estou andando, mas todo mundo está trabalhando. Eles dependem do meu 
serviço". Aí o feitor me tirou do serviço, e me mandou limpar painel. Falei: "Tá bom”. Concordei para não brigar. Pegava o cabo de vassoura e colocava uma estopa. "China, como está indo?" "Está indo. Devagar, mas está indo”. Era o chefão. Aí ele olhou para mim: "Ah, pô, você não tem jeito, não! Vem para cá. Volta lá para o seu serviço." [risos] Aí voltei para meu serviço. Eu controlei minha conduta. Porque eu fiz isso? Se a pessoa perder a conduta, brigar, é mandada embora sem direitos. "Você está enrolando aí!”, "Estou trabalhando. Trabalhando do meu jeito”. Era um cara grandão, media quase dois metros. Magrinho ele. Ele usava uma capa amarela. "Vem cá, Nelson". Andava bem devagar. Ele reclamava. "Pô, não sou obrigado a correr atrás de você. Eu tenho a perna curtinha, você é grandão”. (Nelson)

\subsection{A revelação do agente da ação}

A ação e o discurso são, para Arendt (2005), os modos pelos quais os seres humanos se manifestam uns aos outros, enquanto homens. Por meio da ação e do discurso o ser humano revela-se aos outros. Diz a autora:

Se existe relação tão estreita entre ação e discurso é que o ato primordial e especificamente humano deve, ao mesmo tempo, conter resposta à pergunta que se faz a todo recém-chegado: 'Quem és?' Esta revelação de quem alguém é está implícita tanto em suas palavras quanto em seus atos; contudo, a afinidade entre discurso e revelação é, obviamente, muito maior que a afinidade entre ação e revelação, tal como a afinidade entre ação e início é maior que a afinidade entre discurso e início, embora grande parte, se não a maioria, dos atos assuma forma de discurso. (p. 191).

Assim, a identidade única e singular revela-se "na conformação singular do corpo e no som singular da voz." (ARENDT, 2005, p. 192). E é a companhia de outros homens, em situação onde se está "com" alguém, e não "pró" ou "contra" alguém, que acontece a revelação.

Por que tais narrativas, como as anteriormente transcritas, são tão significativas para os depoentes? Os episódios contados revelam o agente da ação, revelam "quem" são eles. Uma ação iniciada e uma revelação da identidade através do discurso iniciam um processo 
que emerge como história de vida do iniciador. Esta história afeta de modo singular a história de vida daqueles que com ela entram em contato. Sobre ela, diz Arendt (2005):

O único 'alguém' que ela revela é o seu herói; e ela é o único meio pelo qual a manifestação originalmente intangível de um 'quem' singularmente diferente pode tornar-se tangível ex post facto através da ação e do discurso. Só podemos saber quem um homem foi se conhecermos a história da qual ele é o herói - em outras palavras, sua biografia; tudo o mais que sabemos a seu respeito, inclusive a obra que ele possa ter produzido e deixado atrás de si, diz-nos apenas o que ele é ou foi. (p. 198-199).

Se recorremos a Benjamin (1994), vemos que a narrativa é a forma de passar a experiência de alguém. O memorialista, que narra os episódios dos quais participou, não está apenas contando sua experiência, mas ativamente está revelando quem ele é. 


\section{TRAJETÓRIAS DE FORMAÇÃO POLÍTICA}

\subsection{Trajetórias grevistas ${ }^{11}$}

Vejamos a seguir o que estamos chamando de "trajetórias grevistas", ou seja, o caminho percorrido pelo trabalhador nos anos antecedentes à greve, durante os períodos de greve e também pós greve, considerando seus efeitos e resultados.

\subsubsection{A resistência no chão da fábrica}

Durante a década que antecedeu o ciclo grevista iniciado em 1978, houve por parte dos metalúrgicos uma reação às condições de trabalhado por eles experimentadas. Em pleno regime militar, qualquer tipo de manifestação mais visível contra o patronato seria violentamente reprimido. Essas reações eram marcadas pela astúcia e pela clandestinidade.

Nelson lembra-se das sabotagens sobre a produção:

Para começar teve o "tartaruga", a gente trabalhava bem devagarzinho. "Hoje é tartaruga!”, aí todo mundo trabalhava bem devagar, bem devagarzinho. Eu era da produção. Aí chegava e parava: "Vamos parar, todo mundo!’. Aí começava tudo de novo. (Nelson)

Frederico (1979) constata diferentes formas de sabotagem à produção, que iam desde desaceleração na linha de montagem até danos intencionais (mas com intencionalidade disfarçada) às peças, como produzi-las com defeito ou derrubar uma pilha de peças "sem querer".

11 Como apontado anteriormente, Rafael não participou das greves, e tampouco relata paralisações ou participação em movimentos sociais, o que faz com que não apareça nenhum trecho de seu depoimento nesta sessão. 
Tal tipo de resistência estava ligado a pequenos grupos e geralmente não representava uma mobilização coletiva de uma categoria profissional, e nem mesmo de uma classe.

Manifestações mais organizadas coletivamente eram planejadas fora da vista dos patrões e supervisores, conforme relata Wilson.

E essas pessoas eram as pessoas que a gente reunia, vinham para o Sindicato, discutíamos e debatíamos com eles e eles eram os formadores de opinião. Então a gente tinha toda essa questão. E lógico que nossa questão mesmo era o banheiro. Nossas reuniões, nossas assembléias dentro da fábrica eram no banheiro. Então a gente ia para o banheiro, e tinha um grupo lá. A gente debatia, voltava dentro do prazo na hora do almoço. Então a gente sentava e discutia. Até que a gente conquistou na fábrica o direito de fazer uma vez por mês uma assembléia com o pessoal. Então a gente teve essa conquista. A gente sentava. Era uma hora por mês, a gente parava toda a fábrica e ia fazer reunião com o pessoal. (Wilson)

Adão também relata a clandestinidade do movimento, e o cuidado que os operários tinham de ter com a espionagem.

A gente tinha que ter bastante jogo de cintura para driblar os espiões dentro da firma, e conseguir participar desse movimento muito camuflado. Estas reuniões tinham que ser feitas em lugares não divulgados, senão tinha muitos observadores que traziam informação. (Adão)

Para Dimas, é na fábrica que começa a organização operária.

A experiência da gente é essa. A gente fala das greves da categoria, das greves gerais de 78, 79 e 80, mas a experiência da gente começa dentro da firma, dentro do chão de fábrica. Essa que é a experiência que a gente tem. É lá que a gente define, é lá que a gente faz. Quando você sai para fora, você sai junto, e já sai sabendo fazer. Já sai preparado. (Dimas)

Mas, se de acordo com Dimas, é na fábrica que se define o movimento, foi fora dela que algumas mediações sociais importantes influenciaram diretamente na eclosão das greves. Sader (1988) refere-se a "matrizes discursivas [...] entendidas como modos de abordagem da 
realidade, que implicam diversas atribuições de significado.” (p. 143). Dentre elas, aparecem nos depoimentos dos entrevistados a Igreja Católica e o chamado Novo Sindicalismo.

\subsubsection{Igreja Católica e movimentos de bairro}

Adão é o único dos entrevistados que fez parte de movimentos ligados à Igreja Católica, na década de 70. Teve contato com dois padres que foram muito importantes na sua formação política, os quais apresentaram as ideias sobre a sociedade capitalista, como ela funciona, como se obtém lucro etc. Foram em cursos oferecidos pela Pastoral que Adão começou a entrar em contato com conceitos, como mais-valia, exploração do trabalho e mesmo a aprender a calcular o lucro das empresas. Sua ligação com a Igreja era menos religiosa e mais política.

E davam essas palestras pra gente, e iam mostrando pra gente como é que funcionava essa questão. A partir daí ele mostrou pra gente como é que funcionava a sociedade, como a sociedade estava dividida entre uma classe dominada e uma classe dominante. Isso foi muito importante. Fez com que no decorrer do tempo a gente fosse descobrindo uma coisa aqui e outra coisa ali, as falcatruas ideológicas, que surgiam propriamente dentro da igreja, com seu rebanho todo. Ensinou muito pra gente. Portanto, até hoje, não me desvinculei da Igreja Católica. (Adão)

O meu despertar da consciência crítica se deu nos papos que nós falamos há uns minutos atrás, naquelas palestras que a gente teve que eu fui ver que o peão era explorado, e continua sendo. Cada vez exploram de um jeito. Mas dentro da fábrica, naquela época, não tive condições de crescer coisa nenhuma. (Adão)

Eu comecei a ter essas formações na chamada... um grupo que tinha, é um grupo muito importante no meu ponto de vista: ACO, que é Ação Católica Operária. Nisso eu aprendi muita coisa. Aprendi bastante mesmo! Foi essa questão de algumas palestras que a gente ia aos domingos. Aí já não era dentro da igreja, já era numa associação, mas o mesmo padre que celebrava a missa, tinha uma cabeça muito arejada. Um italiano. Eram um italiano e um francês. (Adão) 
Sobre esse padre, Adão diz:

Mas essa foi uma das pessoas que mais colaborou, que começou a mostrar pra gente como que funcionava a mais-valia. A questão da força de trabalho versus capital. Sei que ele fazia o convite a muitas pessoas. Isso normalmente acontecia aos domingos, às três ou quatro horas da tarde, mas já não era no salão da igreja, era numa associação de bairro. (Adão)

Tive o privilégio de estar fazendo isso aqui no meu bairro mesmo. Vinha o pessoal já com mais informação e passava para gente. Começaram a mostrar para a gente a questão do capital versus trabalho, que era dado outro nome, que era mais-valia. Com isso a gente aprendeu bastante, muitas pessoas aprenderam bastante. Ai começaram a mostrar em termos de números, faziam algumas simulações para saber quanto você rendia de lucro para trabalhar na empresa. Já vinha a informação de como os metalúrgicos de países desenvolvidos viviam. Era bem diferente do nosso mundo aqui. (Adão)

Adão conta, portanto, sobre a aproximação da igreja com as associações de bairro. Dimas e Wilson não estavam ligados à Igreja Católica, mas fizeram parte de associações de bairro.

Eu fiz parte de movimento de bairro. Eu fiz parte de conselho de bairro aqui na Ferrazópolis. Fui coordenador do núcleo do bairro de Ferrazópolis. A gente teve muitas discussões, muitos debates, trazia muitas pessoas. Eu sou uma pessoa que busca alguém para fazer palestras. Então, sempre alguém para desenvolver algum trabalho. Se tem alguma coisa, eu trago. E dentro do bairro, no núcleo, tinha uma época que a gente não tinha nem lugar para o pessoal ficar dentro. O pessoal ficava na rua. Sempre vinha muita gente, porque a gente sempre trazia alguém para falar. (Wilson)

Dimas conta da aproximação do Sindicato com os movimentos de bairro.

O Lula, o Djalma, falavam muito para a gente nos bairros, nos botecos, em casa, comunicar os amigos. Conscientizar as pessoas do movimento que a gente estava fazendo. "Não saia daqui, e cuidado para não ser investigado por alguém, porque pode acontecer alguma coisa. Se quiserem, vão pescar, mas sempre tenha cuidado. Não se precipite em nada. Mas a mobilização é importante. Não só aqui, mas levando para o bairro, para a igreja, para a sociedade de amigos. Leve para qualquer lugar. 
Mas não deixe de fazer". Isso acho que foi muito positivo, porque aumentou muito o movimento. Foi um movimento muito grande. E eu fazia minha parte nisso aí. Não só eu, como outros. (Dimas)

Sader (1988), em seu estudo sobre a emergência dos movimentos sociais nas décadas de 70 e 80, afirma que "as classes populares se organizam numa extrema variedade de planos, segundo o lugar de trabalho ou de moradia, segundo algum problema específico que as motiva ou segundo algum princípio comunitário que as agrega.” (p. 313). Podemos perceber nos trechos apresentados como os movimentos se articulavam e prestavam solidariedade uns aos outros. A trajetória de um metalúrgico grevista está pautada não apenas pelo movimento e pelo discurso de sua categoria profissional, mas por todos os ambientes de socialização pelos quais cada pessoa está associada.

\subsubsection{Conversas informais}

As conversas entre os companheiros metalúrgicos, em ambientes mais informais, também contribuíram muito para que surgisse e se desenvolvesse um interesse pela política operária. Uma palavra, um convite, uma provocação poderiam instigar o operário a procurar saber do que se tratava o movimento sindical. Os laços de amizade têm um potencial político. Quantas vezes não nos interessamos por um assunto por conta de um amigo que se dedica com emoção a ele!

E surgiu, através de formação nas entidades, táticas de como se organizar no local de trabalho, é onde eu tive um sucesso maior com os colegas. Porque tinha aquele pessoal que você ia conversando com um, conversando com outro, na hora de almoço, na hora de entrada e de saída, até que você começasse a conhecer. Um negócio legal também é que tinha um time de futebol, na época, e eu ia bater bola com o pessoal. (Adão)

Na Forjaria São Bernardo, eram o Zezão, José Lopes, o Roberto. O Roberto a gente chamava de Robertão. Ele tem um nome suíço, o sobrenome dele é suíço. Um nome complicado, não lembro agora. O Nelo e eu. E nós tínhamos um grupo de fábrica formado por pessoas de vários setores que formavam o grupo de fábrica. Tinha o José 
Damião, tinha o Jacaré, tinha o Soldado. Mais apelido, a gente conhecia mais por apelido. (Wilson)

Não foi só da Forjaria e da Mercedes que eu fiz amizades, mas em outras fábricas também. Devido a muitos seminários, muitos encontros, de levar jornal na porta das fábricas. Eu saía da Forjaria e ia para portas de outras fábricas. Teve uma vez que eu entrava das sete às cinco. Então eu saía de casa às cinco horas da manhã, vinha para o Sindicato e depois ia para a porta de outras fábricas para entregar a Tribuna Metalúrgica, junto com os diretores. Então nisso a gente pegou conhecimento. Então é essa amizade que a gente tem, esse conhecimento. O pessoal vem aqui, bate um papo, dá risada, conta casos do que aconteceu. Isso é muito gratificante, porque as pessoas vêm aqui na Associação, quer saber se a gente ainda está aqui, se encontra com a gente, vêm, aqui para sentar, dar risada. (Wilson)

\subsubsection{O Sindicato}

O Sindicato dos Metalúrgicos de São Bernardo do Campo e Diadema tem papel importante nas trajetórias grevistas dos trabalhadores. Embora o Sindicato não tenha iniciado a greve de 1978 (a primeira depois de muitos anos sob repressão do governo militar), foi por meio de seu discurso e sua proposta de atuação junto à base que muitos trabalhadores puderam entrar em contato com as questões que viriam a determinar o início do ciclo grevista.

É interessante notar como aparecem as relações dos entrevistados com o Sindicato.

Adão começa a se interessar pelo Sindicato quando seu patrão adverte os operários acerca de um "comunista" que estava montando uma chapa para a direção do mesmo, em 1976. Quem encabeçava a chapa era Lula, de quem Adão escutou pela primeira vez o discurso que defendia um sindicato voltado para o interesse dos trabalhadores.

Me lembro bem dessa questão do ABC, pelo fato de eu liderar o setor, mesmo com as limitações que eu tinha, a gente foi chamado para algumas reuniões com a direção da empresa, aonde eles colocaram a preocupação que eles tinham com a questão... tem que citar o nome da pessoa, que no caso era o Lula na época. Os boatos que andavam... em 76 eu não tinha tanto contato com ele, eu fui conhecendo através desses papos de reunião lá na empresa. O diretor industrial nos reuniu e disse: "Olha, vamos tomar muito cuidado que tem um nordestino aí, barbudo, que está com 
uns discursos de comunista". Isso foi em 76. "Ele está fazendo de tudo para ganhar as eleições do Sindicato aqui no ABC e formou um novo Sindicato aqui no ABC". Isso foram palavras do diretor dessa empresa. "Se ele ganha o Sindicato aqui no ABC pode acontecer um monte de coisas ruins". Aí ele citou: "Pode haver um monte de desemprego, um monte de firmas podem ir embora. Porque vocês imaginam, um comunista... não vai dar certo isso aí. Vamos ver no que vai dar. Então vocês fiquem atentos com o pessoal que trabalha com vocês. E vocês fiquem atentos com o que pode acontecer se ele vier a ganhar esse Sindicato". E aí eu procurei me informar que tipo de coisa era essa. Como já era sócio "automático" - de São Paulo me transferi pra lá - eu disse "Poxa, vou precisar conhecer isso melhor". E aí tentei procurar conhecer isso aí, aí que eu fiquei sabendo que o Lula - Luís Inácio Lula da Silva, mas todo mundo o conhecia por Lula - fez uma reunião com o pessoal que compunha a direção do Sindicato lá do ABC que não era simpático à maneira como o Sindicato dos Metalúrgicos de São Paulo era conduzido. (Adão)

Adão relata que se tornou sindicalizado automaticamente, assim que foi contratado pela empresa para a qual trabalhava em São Paulo. Dentre tantas fichas cadastrais que teve que preencher uma delas era para se tornar sócio do Sindicato dos Metalúrgicos de São Paulo. Quando a empresa se mudou para Diadema, ele se tornou, automaticamente, sócio do Sindicato de São Bernardo e Diadema. No entanto, Adão só procurou saber do que se tratava essa questão quando seu chefe o alertou para o "perigo comunista".

Com a vitória da chapa encabeçada por Lula, nas eleições do Sindicato, o programa de ação de sua chapa começou a ser implementado.

O Sindicato começou a chamar os operários pra ir até a sede do Sindicato. E aí já foram proporcionadas um monte de palestras, de cursos, se criou apostilas, se criou tribunas. Então tudo isso aí era um meio de formação. (Adão)

Wilson também menciona os debates e discussões promovidos pelo Sindicato.

E essas pessoas eram as pessoas que a gente reunia, vinham para o Sindicato, discutíamos e debatíamos com eles e eles eram os formadores de opinião. (Wilson)

Dos cursos que o Sindicato deu eu fiz todos. Só se tiver um novo, agora, que a gente não sabe. Eu tenho mais diploma do Sindicato, de cursos, seminários, formação de formadores, formadores de formadores. Tive presença dando aula no Sindicato, na 
escola do Sindicato, de OSPB ${ }^{12}$. Fiz o curso de expressão e oratória, dentro do Sindicato. (Wilson)

Wilson menciona também como o Sindicato mobilizava os trabalhadores, incentivando-os a aprender como fazer os cálculos dos salários, e consequentemente fazendoos notar como os índices de reajuste eram forjados pela política salarial do governo.

E também a inflação naquela época era enganosa, porque os militares diziam um valor para a inflação, e era outro totalmente diferente. Era o dobro ou o triplo daquilo. E a gente via no nosso salário a defasagem. [...] Inflamavam o pessoal. $O$ pessoal já começou a fazer contas. O metalúrgico começou a aprender a fazer cálculo. Então você via no pé da máquina, na hora do almoço, o cara fazendo conta de quanto iria ser o salário dele. E aquilo movimentava. Era um chamariz que a diretoria do Sindicato fez. (Wilson)

Wilson conta ainda sobre alguns aprendizados da prática política.

Mas a assembléia era sempre assim: com o Sindicato aqui eu aprendi muito a dar a palavra às pessoas, e não determinar quem ia falar. E o Lula sempre falou uma coisa que era a seguinte: você tem que conversar com aquela pessoa que é contra você. Porque ele que tem a crítica vai mostrar seu defeito. Quem te elogia não vaifalar seus defeitos, vai sempre te elogiar. Mas aquele que faz a crítica sua é com quem você tem que conversar, porque você vai melhorar dentro da crítica que ele fala. Era uma coisa que a gente via ele falar muito. (Wilson)

Wilson fala com entusiasmo do Sindicato, da força, da coragem e da paixão sentidas a partir da luta por um coletivo. O Sindicato é para ele uma escola.

Na realidade o Sindicato dos Metalúrgicos foi, é e continuará sendo uma escola para a gente. Eu acredito nisso porque muda a direção, mudam os diretores e a gente vê que ele mantém um padrão de articulação, como exemplo para os outros, sem medo de... errar todo mundo erra, né? Mas eles têm essa força e a coragem de estar mudando todo o conceito da história do sindicalismo no Brasil. (Wilson)

${ }^{12}$ Organização Social e Política Brasileira - matéria obrigatória nas escolas durante o governo militar, aparentemente foi lecionada em um curso do Sindicato, provavelmente com teor diferente daquele que os militares desejavam. 
Na realidade o Sindicato é uma escola. Aí você começa a se apaixonar por aquilo. Começa a lutar com mais garra, mais força. Começa a conhecer aquela mudança de ter um conhecimento maior. E começa a se apaixonar pela luta, porque ela é gratificante. Não a luta por si, você lutar para você. Mas lutar pela comunidade. (Wilson)

Nelson traz uma visão do Sindicato que dá valor à participação das bases.

Sempre incentivando as pessoas para ser sócio do Sindicato, para lutar pela categoria. Tinha muito pelego que não assinava. Mas a maioria assinou. Tinha muitos que assinavam, mas depois ficavam reclamando do Sindicato. Aífalava para eles que o Sindicato é uma coisa boa para a pessoa, [inaudível] nosso salário, e tem que lutar pelos nossos direitos. Só o Sindicato não vai. Tem que ajudar o Sindicato. "O Sindicato não faz nada”, mas nós temos que ajudar o Sindicato. (Nelson)

Dimas fala da liderança dos diretores do Sindicato na condução das greves e das reivindicações.

A participação do Sindicato, do qual o Lula era presidente... Tinha também o Djalma Bom, que era uma pessoa muito atuante. Tinha o Alemãozinho. Expedito Soares. Tinha o Rubão, que era o vice-presidente do Lula. Eu acho que a participação deles foi muito boa, porque eles conseguiram liderar todos os metalúrgicos, mobilizar todos os metalúrgicos, para poder participar. Eles não ficaram sozinhos. Então foi uma liderança muito perfeita, a melhor que teve até hoje, eu acho. (Dimas)

Já Reinaldo tem uma aproximação diferente do Sindicato. Ele já estava aposentado em 1978, quando estourou a primeira greve, e Lula o chamou para fazer parte da primeira gestão da diretoria da AMA.

Ajudei o Lula a formar esta entidade em 1978. Ele era na época o presidente do Sindicato, e ele: "Tem muito aposentado. Não estou dando conta, não". Perguntei: "E qual é o melhor? Manda embora, ué!”. Ele falou: "Não! Vou reuni-los em um grupo, em um lugar só pra eles”. Falei: "Como? Como reunir?”, "A gente faz uma associação de aposentados. O pessoal da ativa fica de um lado, continua fazendo tudo que estão fazendo. E os aposentados vão seguir seu caminho", eu falei: "Mas nós aposentados não temos essa experiência toda pra chegar e tocar nosso destino", "Nós vamos enfiar vocês na canoa e nós vamos ensiná-los a remar”. (Reinaldo) 
Reinaldo tem uma admiração um tanto paternalista por Lula (apesar de ser bem mais novo). Esse diálogo mostra quase uma imposição. Lula é o líder que sabe conduzir os trabalhadores, e a relação de Reinaldo com o Sindicato é ligada a maior parte das vezes a Lula.

\subsubsection{Treinamento para a greve}

Adão menciona frequentemente a importância de se preparar para a greve. As táticas, para divulgar o que era relativo ao movimento reivindicatório, tinham que ser pensadas com inteligência suficiente para que a repressão do regime militar não as detivessem.

Só que lá no início, nós estamos falando de década de 70 ainda, isso era muito complicado. Que até para você distribuir papel pra você divulgar uma palestra, ou divulgar uma nota, ou um recado que você quisesse passar. A gente não tinha liberdade de forma nenhuma de ficar com papelzinho debaixo do braço folhetando, como se faz hoje. Hoje é fácil, naquela época não era assim. Pra gente espalhar uma notícia do Sindicato, ou uma possível greve, ou denunciar uma possível falcatrua, os militantes tinham que passar por um processo de formação, que tinha que se dar muito rápido, senão você não conseguia acompanhar a evolução do tempo. Como se dava isso? Os primeiros passos foi alguém fazer esse documento, bem escondido, que era pra ninguém saber quem eram realmente os autores disso aí. Então se arrumou um monte de nomes de autores conhecidos, que eram companheiros, e outros nomes mais que eles davam. E pra distribuir era assim: digamos que nós dois estávamos com a incumbência de espalhar essas notícias em uma determinada fábrica. Então um de nós ia na frente, como se um não conhecesse o outro, com um pacote. De repente, você deixava isso cair, e o que vinha atrás, despercebidamente, tropeçava naquilo e espalhava, e aí pessoal passava e catava e começava a ler. E aí, ninguém sabia quem deixou cair. O cara sumia. Cada um entrava pra sua fábrica e não tinha nem como perguntar como isso funcionava. E isso começou a funcionar de militante pra militante. Era uma forma que a gente tinha de divulgar como se organizar dentro do Sindicato. (Adão)

Só que a gente usava essas táticas. Digamos assim que eu trabalhava a um quarteirão daqui, eu ia fazer esse trabalho a dois quilômetros daqui. Fazia esse trabalho e voltava pra casa de ônibus, ou de outros meios que dessem pra vir, e ninguém ia descobrir quem foi que fez isso aí. Ia trabalhar normalmente, se por alguma 
eventualidade qualquer fosse levantada alguma suspeita, eu tinha como provar que não era eu, porque tal hora eu estava na fábrica, tinha o cartão marcado. Uma coisa até bem organizada. E essas coisas foram se espalhando, Guilherme. Até ir pegando outras dimensões. (Adão)

Adão e Wilson falam da diferença entre o trabalhador que havia se preparado para enfrentar a dureza da greve e aquele que não havia passado por um treinamento. Greve é um estado de guerra, segundo Adão. Ninguém vai para a guerra sem saber o que fazer.

E muitas vezes pessoas que se alteravam, falavam mal do governo, já saíam presas de dentro do Sindicato. Ou eles saíam lá fora, já estavam marcados, e o camburão já estava esperando para prendê-lo. E a maioria do pessoal então pedia para a pessoa ser branda. E tinha também as reuniões secretas. Muitas reuniões secretas para ver qual era o perfil, como a gente ia se portar, como a gente ia se defender. (Wilson)

Aí, falando desses acontecimentos de 79, nós tivemos que avançar bastante em aperfeiçoamento de greve. Sem fazer esses treinamentos, essas palestras, esse material que o pessoal leu... ou deu pra alguém ler, porque a maioria na época não sabia ler. [...] Por isso que a greve de 80 já foi mais organizada. Se tornava quase impossível as empresas e a polícia saber quem era quem. Nessa daí, eu não tenho dúvida nenhuma, que muita gente inocente, principalmente os que não gostavam muito de participar de uma reunião no Sindicato, nas comunidades de base, as associações... esses que faziam esse treinamento já estavam um pouco mais livre de sofrer as penalidades porque já sabiam como agir numa greve. Agora esse que não queria nem saber era o primeiro que levava pau. Ele se expunha. Vamos supor que nós dois estávamos lá. Por mais que a gente seja amigo, naquele momento ali, de corpo a corpo, depois que você está não mão da polícia, do corpo a corpo, a não ser que eu fale: "Morre nós dois". E o resto? Muito confuso esse troço. Pra gente foi bastante confuso nessa parte. Até se atingir uma grande parcela. E aí foi onde começaram a surgir essas reuniões de Sindicato, palestras. (Adão)

Adão conta da importância da leitura e da mediação de uma cultura letrada para o treinamento direcionado à greve. A organização da greve, de acordo com ele, está diretamente relacionada a esse tipo de formação.

Sem fazer esses treinamentos, essas palestras, esse material que o pessoal leu... ou deu pra alguém ler, porque a maioria na época não sabia ler. Hoje mudou-se o quadro. Tem analfabeto, mas não na mesma dimensão. Naquela época era uma 
infinidade de gente que não sabia ler nada. Alguém lia, e as pessoas prestavam muita atenção. Nós temos entidades aqui, inclusive eu faço parte da direção de uma delas, que teve papel fundamental nisso aí. Isso era feito aos domingos. Não precisava nem fazer hora extra. Aos domingos a gente ia pra lá. Tinha alguém que já tinha estudado um pouco, já tinha avançado, e mostrava pra gente a relação capital e trabalho. Foi quando a gente começou a aprender esse troço aí. Como se dava a relação capital e trabalho, ou seja, a mais-valia. A alta produção, o cansaço do cara, como a empresa lucrava. Isso começou a ser estudado e passado para os operários. Foi fundamental pra abrir a cabeça pra ter uma greve mais organizada. Por isso que a greve de 80 já foi mais organizada. (Adão)

\subsubsection{As greves}

Wilson conta do impacto de participar de uma greve pela primeira vez, sem saber exatamente o que estava acontecendo.

A primeira greve que nós entramos foi em 79, não foi em 78 . Em 78 só parou a Scania, ficaram três dias. Em 79 nós ficamos 16 dias parados. Eu morava próxima a Piraporinha e vinha a pé para a Forjaria. E para mim era uma experiência, porque eu nunca tinha visto uma greve, pois eu tinha vindo do interior. Aí eu vi todo mundo andando para a firma, porque a greve foi decretada de madrugada, e eu entrava das duas às dez. Eu vim e estava tudo parado. Ali na Avenida Piraporinha não era duplicado, era mão dupla com uma faixa no centro. E parecia festa. Então eu vim para a firma, e vinha até para trabalhar. Então quando eu cheguei perto da firma o pessoal, os colegas, falaram: "Olha, está tudo parado hoje”. Eu falei: "Nem vou chegar lá". Então fiquei ali na esquina com o pessoal. Depois nos chamaram para o Sindicato, viemos aqui para o Sindicato e foi feita uma assembléia. Já haviam decretado a greve de manhã cedo. Então ficamos 16 dias parados em 79. Foi a primeira greve que eu participei. (Wilson)

Dimas e Adão relatam como, durante a greve, os trabalhadores entravam em contato com os temas relativos às reivindicações.

As reivindicações eram sobre campanha salarial. E também a carga horária, redução da jornada de trabalho. E também as causas sociais. As causas sociais também eram 
pauta das negociações. Porque o contrato coletivo dos metalúrgicos aqui favoreceu muita coisa. Favoreceu os que têm problemas de deficiência, favoreceu as mulheres, gestantes. Ampliou as causas sociais. Então foi criado o contrato coletivo na base aqui, especificamente dos metalúrgicos do ABC. E salarial. Foi uma coisa difícil, foi conquistado, mas não foi o que a gente queria na época. Então são essas as pautas. (Dimas)

A partir de 78 começou a acontecer o crescimento da participação das pessoas. Não posso dizer com muita certeza se é consciência ou se é conseqüência do que estava se passando naquela época, o salário sendo achatado, sem direitos quase nenhum. Acidentes de trabalho: isso é o que mais rolava, e era tudo camuflado. Então fica até difícil eu falar pra você: o pessoal começou a tomar consciência. Ou não... corrigindo: eu acho que o pessoal começou a tomar consciência, mas naquele momento você não pode dizer que era um pessoal que estava fazendo a coisa conscientemente. Eles começaram a tomar consciência a partir desses acontecimentos. Cada acontecimento era pra nós, eu e tantos outros colegas, uma etapa de aula que a gente teve. Na luta que a gente ia, cada acontecimento era mais uma lição que você aprendia para dar os próximos passos. (Adão)

É interessante notar como Adão relata o avanço da conscientização dos trabalhadores a partir do aprendizado de participação nas greves. Ele não sabe dizer ao certo se é consciência ou se é conseqüência do que estava se passando naquela época. Fica a impressão que foi um processo contínuo e integrado com tudo relativo, à época, ao que antecedeu às greves, quando houve pequenas paralisações e atos de resistência no chão da fábrica, passando pela formação política no Sindicato, e nos movimentos de bairro e ligados à Igreja Católica. Para ele, a participação nas greves foi uma lição que levou ao acesso a informações importantes sobre política, legislação, história etc.

Mas eu peguei como lição também que isso, apesar do sofrimento que a gente teve, foi uma etapa que a gente conseguiu aprender também. Ninguém conhecia os direitos que tinham. Coberto por um monte de coisas, mas ninguém lia história, não existia esse negócio de Constituição. Não tinha essa coisa toda. Era fechado. A gente começou a ter acesso a essas informações na década de 80. (Adão)

Adão e Dimas falam de pontos diretamente ligados à vida do trabalhador, que eram discutidos durante as greves. 
Hoje você negocia até participação de lucro. Você nem sabia o que era lucro, hoje você faz discussão de participação de lucro, de resultados. Mas é fruto de lutas do passado. (Adão)

As reivindicações eram sobre campanha salarial. E também a carga horária, redução da jornada de trabalho. E também as causas sociais. As causas sociais também eram pauta das negociações. Porque o contrato coletivo dos metalúrgicos aqui favoreceu muita coisa. Favoreceu os que têm problemas de deficiência, favoreceu as mulheres, gestantes. Ampliou as causas sociais. Então foi criado o contrato coletivo na base aqui, especificamente dos metalúrgicos do ABC. E salarial. Foi uma coisa difícil, foi conquistado, mas não foi o que a gente queria na época. (Dimas)

Dimas fala também do impacto político que a greve tem em termos de mobilização, mencionando a necessidade de criar fatos políticos.

Eu acho que foi uma evolução. Acho que tudo, para melhorar, precisa de um sistema de evolução. Nada melhora só com diálogo, só com caneta. Você tem que criar um fato político. Se você não criar um fato político, não desenvolve nada. Então é isso que foi feito naquela época. Foram criados tantos fatos políticos que nós mobilizamos o Brasil todo. Então foi muito bom. (Dimas)

Nelson e Dimas contam sobre as assembleias durante as greves. Percebemos nas falas uma diferença importante: Nelson relata que o diretor do Sindicato falava alguma coisa, enquanto Dimas conta de um aprendizado importante da greve, que se trata do direito à palavra, não apenas por parte da direção sindical.

Foi em 80. Teve outra em $69^{13}$. Foi assim: nós estávamos reivindicando reajuste. Os patrões não quiseram pagar. Aí de manhã vínhamos para o Sindicato. Aí antes de entrar, a gente parava em frente à fábrica. Ficavam todos lá. Aí tinha assembléia na Volkswagen, aí nós entrávamos. Antes de entrar, a gente ficava do lado de fora da Volks. Aí escutava o diretor do Sindicato falar alguma coisa. (Nelson)

Era o seguinte: a direção falava o que tinha que fazer, a pauta de reivindicações, como estava o movimento. Nós estávamos sendo reprimidos, como é que nós tínhamos que nos comportar, era um negócio que não poderia ser muito aberto. E também dava a palavra para as pessoas falar. Não era só a diretoria que falava. Os metalúrgicos

\footnotetext{
${ }^{13}$ Nelson provavelmente quis dizer "79".
} 
levavam, discutiam, aceitavam a opinião. Então foi um movimento histórico no qual participou a diretoria do Sindicato junto com os metalúrgicos. A diretoria não ficou sozinha. Tiveram respaldo da categoria. Isso em todos os sentidos. (Dimas)

\subsection{Greve e consciência política}

\subsubsection{O salário}

Todos os entrevistados constatam que pelo menos uma das reivindicações das greves metalúrgicas é o reajuste salarial. Mas nem todos relacionam a desvalorização do salário à política governamental. É o governo que decidia o índice de reajuste salarial, no período militar, e os índices de reajuste eram fixados sempre proporcionalmente abaixo do aumento do custo de vida, medido pelo DIEESE (ABRAMO, 1999; ANTUNES, 1992). O Sindicato denunciava que, em 1973, o índice de reajuste salarial concedido pelo governo foi baseado em dados fraudulentos, fato que foi denunciado pelo Sindicato em 1977 (ANTUNES, 1992). Mas nem todos citam isso, relacionando o reajuste salarial às condições privadas de vida e consumo. Ou seja, é relatado apenas o sofrimento cotidiano causado por uma política nacional.

Em cima do salário. Era para reajustar nosso salário. Não lembro quanto era, mas era para reivindicar o salário. Era muito pouco que a gente ganhava e a firma não queria dar. E aí nós fizemos essa greve. (Nelson)

Geralmente era ordenado. Só se falava em ganhar bastante. A conversa lá dentro era: “Estou ganhando pouco, estou trabalhando muito”. Todo dia tinha reclamação. (Reinaldo)

Quanto aos salários, Adão e Wilson contam de como o Sindicato ensinava os trabalhadores não apenas como fazer os cálculos da desvalorização salarial, mas também o real significado da desvalorização salarial. 
E também a inflação naquela época era enganosa, porque os militares diziam um valor para a inflação, e era outro totalmente diferente. Era o dobro ou o triplo daquilo. E a gente via no nosso salário a defasagem. [...] Inflamavam o pessoal. $O$ pessoal já começou a fazer contas. O metalúrgico começou a aprender a fazer cálculo. Então você via no pé da máquina, na hora do almoço, o cara fazendo conta de quanto iria ser o salário dele. E aquilo movimentava. Era um chamariz que a diretoria do Sindicato fez. (Wilson)

Aí começaram a mostrar em termos de números, faziam algumas simulações para saber quanto você rendia de lucro para trabalhar na empresa. Já vinha a informação de como os metalúrgicos de países desenvolvidos viviam. (Adão)

\subsubsection{Direitos trabalhistas}

Também as leis que podem proteger o trabalhador metalúrgico de acidentes de trabalho, que prevê horas de descanso e férias, que prevê pagamento de horas extras, assim como limite de horas extras, foram introduzidas aos trabalhadores pelo Sindicato e pelos movimentos sociais.

Dimas fala da reivindicação sobre a criação de contratos coletivos de trabalho, um ponto defendido pelo Sindicato em suas reivindicações.

Acho que foi uma passagem muito boa, porque teve uma evolução. Criou-se uma outra cara para os movimentos. O movimento se estendeu mais, criamos os contratos coletivos. Acho que essa greve ajudou em muita coisa para os trabalhadores. Inclusive para derrubar a ditadura que estava aí. (Dimas)

No trecho a seguir, Dimas relaciona a importância dos contratos coletivos como garantia de condições de trabalho mais dignas, além do que ele chama de causas sociais ligadas a direitos de grupos específicos de trabalhadores, como as mulheres e os deficientes físicos.

As reivindicações eram sobre campanha salarial. E também a carga horária, redução da jornada de trabalho. E também as causas sociais. As causas sociais também eram 
pauta das negociações. Porque o contrato coletivo dos metalúrgicos aqui favoreceu muita coisa. Favoreceu os que têm problemas de deficiência, favoreceu as mulheres, gestantes. Ampliou as causas sociais. (Dimas)

Wilson comenta sobre o Sindicato ter enviado um médico e um advogado à fábrica para fazer valer a legislação sobre o trabalho noturno.

Aí teve outra coisa, que nós trabalhávamos à noite. Aí foram um médico e um advogado do Sindicato na firma. A lei fazia com que o pessoal que trabalhava à noite era 52 minutos, e não 60 minutos. Ele tinha que trabalhar oito minutos a menos que de manhã. E teria que ter uma hora de janta. E nós trabalhávamos direto. Então pegávamos das dezoito horas às seis da manhã. Estava totalmente errado. Aí a firma teve que fazer uma adaptação nesse horário. Então o pessoal entrava às dez horas, tinha uma de almoço. E com isso tinha insalubridade, tinha uma série de coisas acrescentadas ao salário. (Wilson)

Wilson e Adão contam da importância do Sindicato para a garantia de outros direitos relativos à segurança do trabalho.

A gente brigou muito na Forjaria. Melhores condições de trabalho. A gente conquistou o macacão. A gente passou a não pagar mais o macacão, o sapatão. E quando rasgava, a gente ia lá e trocava. Então houve uma certa mudança. Tivemos muitas conquistas na Forjaria São Bernardo. A gente falava: era a idade da pedra. Você tem que trabalhar com aquilo que o pessoal determina. Então, com essa mudança, a gente acabou conquistando muita coisa. Hoje tem empresa que lava até a roupa dos funcionários. Mas naquela época, além de lavar a roupa, a gente tinha que pagar por ela. Então a gente teve essa conquista. Houve uma mudança muito grande. O layout da empresa também mudou muito. A partir do momento que o Sindicato começou a entrar dentro da empresa, foi ajudando a mudar o layout, para ficar muito mais tranqüilo para as pessoas trabalhar, para trabalhar mais folgado. Antes era uma máquina em cima da outra. Houve algumas idéias dentro do Sindicato que acabaram em uma mudança no layout da empresa. (Wilson)

Ninguém tinha informação dos valores dessas peças, como eram vendidas, pra onde iam. Nem coisa nenhuma. As máquinas eram todas super ultrapassadas. Não tinha protetor, não tinha óculos pra proteção da vista. Luva, aquelas luvas de raspa, grandonas. Mais no sentido de proteger a peça que a própria mão. Então deu para a gente presenciar, infelizmente, algumas vezes, colegas terem o dedo decepado, mão decepada. Isso eu presenciei. [...] E a jornada de trabalho naquela época você sabe, 
era 48 horas semanais, e você ainda era intimado a trabalhar depois dessa jornada, a fazer hora extra. Se você não fizesse, no decorrer do tempo você era substituído. Falavam que você não estava colaborando, que só via seu lado e não via o lado da firma. Então, assim não dava pra a continuar trabalhando lá. Além das perseguições que tinham, acontecia isto. E não tinha nessa época, na firma que eu trabalhei, participação do Sindicato. Apesar de ter alguém que já estava contribuindo pro Sindicato, mas não tinha participação ativa do Sindicato como um todo. A discussão do Sindicato pra valer começou a vigorar de 76 pra cá. Agora não posso negar pra você de forma nenhuma que quando se organizou o Sindicato, o povo tomou consciência e essas coisas foram mudando gradativamente. A gente foi conquistando uma coisa, conquistando outra. Mas foi tudo assim na base da organização, e muitas vezes não dava pra negociar muito na conversa, não. Então a gente tinha que parar mesmo. (Adão)

Essa fala de Adão revela uma articulação entre o sofrimento vivido na fábrica, a intermediação do Sindicato no sentido de garantia de direitos e a conscientização dos trabalhadores, possível apenas por meio da organização coletiva.

Reinaldo e Rafael, a despeito do risco de acidente de trabalho causado pela fadiga, que por sua vez é causada pelo excesso de trabalho, enxergam as horas extras como algo que ajuda o trabalhador a realizar seus sonhos. Sonhos esses ligados ao âmbito privado, geralmente de possuir a casa própria.

Essas horas extras ajudavam. É uma coisa que o Sindicato, e várias pessoas do Sindicato são contra. Mas às vezes dava algum resultado. O Sindicato é contra hora extra. Eles pedem para as pessoas não fazer hora extra. Mas não é de tudo ruim. A hora extra, na visão deles, quando alguém faz hora extra, caberia mais uma pessoa ou duas para trabalhar. Em vez de eu fazer dez, doze, ou quinze horas, poderia se pegar um cara na rua para trabalhar, para fazer mais oito. Nesse lado eles estão certos. A hora extra evita que a firma pegue mais um empregado. Eu concordo com eles. Mas ela não é um mal. A hora extra é um dinheiro que vem a mais no pagamento, e você pode contratar alguém lá fora para fazer algo em sua casa. E com aquele ordenadinho que a gente está acostumado a: recebeu, gastou, recebeu, gastou. Você não consegue fazer nada, fica paralisado. Mas com o extra tem um pouco a mais. Você pega o dinheiro extra, compra um pouco de material, paga o pedreiro, o encanador, o eletricista. (Reinaldo)

É importante saber que as horas extras eram tão aconchegante, tão chamadas pelas indústrias automobilísticas. E também para fazer minha casinha, no meu terreninho. É aquela casinha que meu filho passou por lá. É aquela casinha que meu filho viu e 
chorou de emoção, porque viu a situação que estamos hoje. Se a gente for ver a situação de hoje, mudou da água para o vinho. (Rafael)

Reinaldo ainda chega a comentar a posição do Sindicato em relação às horas extras, e que até acha justo que elas sejam abolidas por conta do aumento do desemprego. É curioso ainda notar que, durante a entrevista, Reinaldo comenta que sofria de doença causada por esforço repetitivo no trabalho.

Adão fala das horas extras como algo que o trabalhador era obrigado a fazer, sob o risco de demissão. No entanto, ele próprio admite ser seduzido pelo aumento do valor do salário recebido no fim do mês.

Você imagina o cara trabalhando a quantidade de horas que trabalhava, até doze horas por dia. Lógico que não eram todas horas normais, entravam as horas extras. Hora extra existia por alguns motivos: ou você fazia hora extra, ou estava convidado a sair do emprego, porque tinha mais gente pra suprir seu lugar. Por outro lado, salário baixo. Infelizmente a gente fazia isso: "Se eu trabalhar duas horas a mais, já vai ajudar no meu salário”. (Adão)

Ao comentar sobre o trabalho na fábrica e o sofrimento causado pelas operações realizadas junto às máquinas, Weil (1996) é clara quanto ao objetivo do avanço tecnológico.

\begin{abstract}
De uma forma geral, uma reforma de importância social infinitamente maior do que todas as medidas classificadas sob o rótulo de socialismo, seria uma transformação na própria concepção das pesquisas técnicas. Até agora, nunca se imaginou que um engenheiro ocupado em pesquisas técnicas sobre novos tipos de máquinas pudesse ter em vista outra coisa que não fosse um duplo objetivo: de um lado, aumentar os lucros da empresa que the encomendou essas pesquisas, do outro, servir ao interesse dos consumidores. (p. 422).
\end{abstract}

A autora completa: "Não só não se pensa no bem-estar moral dos operários [...]; não se pensa sequer em não lhes machucar a carne.” (WEIL, 1996, p. 423).

Os relatos dos depoentes mostram uma sensibilidade ao sofrimento imediato causado pelos ambientes de trabalho insalubres e que oferecem risco de acidentes. Mas a relação entre o sofrimento operário e a obtenção de lucro, tal como Weil a faz, não chega a ser notada nas entrevistas. 


\subsubsection{Consciência de classe}

Ter consciência que a política salarial pode ser manipulada e que existem leis que protegem o trabalhador em seu trabalho, pode levá-lo a reivindicações que amenizem seu sofrimento cotidiano. No entanto, não há garantia que as causas do sofrimento operário (a dominação de classes) sejam combatidas.

Antunes (1993) analisa as possibilidades da greve quanto ao plano da consciência operária.

Concluindo: na medida em que a greve possibilita ao operariado dar passos no sentido de superar a imediatidade, através da articulação de suas causas e motivações, levando-o a avançar qualitativamente no sentido de aprofundar as contradições do capital em sua totalidade e a pensar na problemática do controle social da produção, na medida em que esta articulação entre interesses postos pela imediatidade e interesses mais globais de transformação social for efetivada - o que somente se concretiza quando a ação grevista é resultado de uma teleologia consciente - a greve estará se constituindo em um instrumento real no processo de desenvolvimento da subjetividade do ser social. Se, entretanto, ela não supera o plano da imediatidade e atém aos aspectos isolados da contradição, se não capta suas múltiplas dimensões, se ela não pauta sua ação conduzida por uma direção política consciente, sua significação será muito mais restrita, podendo inclusive impedir, obscurecer ou até mesmo fazer retroceder o movimento da consciência de classe. (p. 211).

Esta pesquisa não se propõe a analisar o avanço ou retrocesso da consciência de classe do movimento grevista, mas sim quais são os fatores que podem levar o trabalhador grevista a ter consciência dos processos que desencadeiam seu sofrimento.

A organização coletiva é um primeiro passo para que, juntos, os trabalhadores possam dar um sentido ao sofrimento cotidiano. Vimos como as associações de bairro, a Igreja Católica ligada à Teologia da Libertação e a organização sindical, além de uma organização no chão da fábrica (mesmo que precária por muitas vezes) constituem um suporte para as lutas populares.

O horizonte utópico que estabelece um operário militante depende não apenas do quanto ele se sensibiliza com o sofrimento, mas do quanto ele entende o sofrimento como 
fruto da dominação de classes. A formação política, que seria um segundo passo, supõe cursos, livros e palestras que informem o trabalhador do funcionamento social e político do capitalismo. Adão e Wilson são quem mais comentam dos cursos e palestras, sendo que o primeiro entra no conteúdo destes, destacando temas como capital e trabalho, mais-valia, lucro etc.

A greve, por si só, não é suficiente para levar o trabalhador a ter consciência da dominação de classes.

Vejamos o trecho a seguir:

A greve é duas coisas: você para por um pedido social, ou para por aumento de salário. Ninguém é inimigo do patrão. Essa história é outra coisa que não é verdade. Os jornais escrevem um monte de coisa. Mas o empregado gosta do patrão. O patrão gosta do empregado. Mas tem horas que o patrão precisa de algo, e você precisa de algo diferente. É essa a diferença. O patrão precisa de uma produção melhor, precisa entregar tantos carros. E você precisa também manter sua família, tratar sua família de um modo melhor que antes. Aí começa o desacerto. Não combinam muito as idéias. Não combinam. O patrão precisa de algo, mas você também precisa de alguma coisa. E daí que nasce aquele atrito. Mas inimizade, não! Não existe. Eu ficar com ódio de você, e você de mim, não! Não existe. Quando termina a greve, parece que ninguém nem comenta. Nem comentário você vê. Cada qual vai fazer sua obrigação, e vai esperar o resultado. O que foi acertado, o que foi conversado, o que foi decidido, tem que aparecer. Tem que aparecer. (Reinaldo)

Este trecho do depoimento de Reinaldo mostra que a superação da divisão capitalista do trabalho não é uma questão para ele.

Já para Adão:

Mas tinha um ponto importante nessa época, Guilherme, eu não sei hoje, como vocês que são novos enxergam isso, eu considerei muito importante naquela época. E continuo acreditando que isso não poderia ter sido perdido de vista de jeito nenhum. Não era só eleger sindicalista ou trabalhador pra cercar ali lá pra cima, mas precisaria fazer um grande número e tentar provar pra elite que o sistema em que a gente vive é um sistema que não funciona. Antes de tudo você teria que derrubar esse sistema. E eu sou um dos que cheguei a defender que não seria via voto pra mudar isso aí. Teria que fazer algumas organizações, mesmo depois que a gente começou a adquirir um pouco mais de conhecimento, a gente começou a conhecer as limitações que a gente tem. A questão da formação, de você conhecer geograficamente seu país, seus pontos estratégicos. Ninguém saberia lidar com armas. Nós chegamos a pensar 
em uma época em querer tomar o poder na base da porrada, da bala mesmo. Chegar, subir a rampa, e falar: "Chega! Agora é nossa vez, já fizeram muita cagada”. Mas, tem uma maioria que pensou diferente e falou: "Não, vamos fazer isso por uma via saudável". Ou seja, na linha de raciocínio de alguns amigos meus "vamos brincar de bobo". Quando você vai conseguir que o sistema capitalista proporcione uma boa condição de vida para o trabalhador? Eu, por exemplo, nunca perdi isso de vista. No conflito capital e trabalho, quem sempre vai levar mais vantagem vai ser patrão. Ele tem o maior poder disso aí. Mas infelizmente... ou felizmente, essas coisas aconteceram. E junto com isso aí, uma coisa bem complicada, junto com esse conjunto de coisas que estava acontecendo, dentro do Sindicato começou a gerar divisão. Tinha aqueles que defendiam essa linha de raciocínio que eu acabei de falar pra você. Tinha outros que defendiam uma outra linha de raciocínio, que tinha que ser no diálogo, no voto, na lei. E aí começou a gerar os conflitos dentro da própria classe trabalhadora: as maneiras de pensar. (Adão)

Para Simone Weil (1996), o ser humano é capaz de suportar muitos sofrimentos. O sofrimento de um escravo é que é insuportável.

Gonçalves Filho (1998) aponta o sofrimento provindo da desigualdade de classes como algo enigmático. "A realidade da sociedade de classes, atravessada pela desigualdade política, participa de um círculo de mensagens enigmáticas e traumáticas.” (p. 52). Ainda afirma que a divisão política é

antiga, sua origem e determinação perderem-se de vista, encontram-se bem fora e bem antes da cena atual, onde são cegamente retomados, onde se renovam e se deformam, onde tão tranqüilamente representamos os papéis de tiranos, tiranetes e tiranizados, como se tratando de um roteiro universal. A humilhação é uma modalidade de angústia que se dispara a partir do enigma da desigualdade de classes. (GONÇALVES FILHO, 1998, p. 53).

Adão resolveu o enigma da dominação junto com seus companheiros, com o auxílio da cultura letrada. E, conforme ele relata, levou muito tempo. 


\section{TEMPO E MEMÓRIA: PASSADO, PRESENTE E FUTURO}

\subsection{Comparações entre passado e presente}

É a partir do presente que se lembra do passado. O presente é a referência, pois não há como não ter vivido a vida no intervalo entre o momento em que aconteceu o fato hoje lembrado e o presente. Lembrar é o trabalho de reconstruir o passado, e o material para essa empreitada está disponível no presente; são os recursos que temos hoje. "A lembrança é uma imagem construída pelos materiais que estão, agora, à nossa disposição, no conjunto de representações que povoam nossa consciência atual.” (BOSI, 1994, p. 55).

O juízo que cada depoente faz dos fatos lembrados acompanha a memória em si. O julgamento é feito de um ponto de vista que parte do tempo presente. Entretanto, esse ponto de vista é também formado pelas experiências do passado.

\subsubsection{Sindicato e entidades políticas}

Adão nunca deixa de lado as perspectivas de projeto político que as entidades sindicais e partidárias tinham na época. É assim quanto ao Sindicato dos Metalúrgicos, ao Partido dos Trabalhadores e à Central Única dos Trabalhadores.

Aí, em São Bernardo, parece que essa doença, apesar da discussão, o discurso que o Lula fez com os objetivos que ele tinha pra criar o Sindicato, só que isso contagiou lá depois. Ele criou o Sindicato com uma filosofia de trabalho, um determinado idealismo. Mas isso contagiou lá, e acabou gerando essa facção, algumas facções dentro do Sindicato, e uma delas, a dominante, que a gente chama de rolo compressor, ou pelego. O nome mais fácil é rolo compressor mesmo, que passa por cima de tudo e predomina a vontade deles. (Adão) 
Bom, daí nasce o PT. Com uma proposta linda, maravilhosa, que a gente poderia, se seguisse aquilo ali, dar certo. A principal maneira era a mudança de sistema. $O$ capitalismo pra gente não ia ter jeito. Eu, por exemplo, nunca perdi isso de vista, até hoje. Está aí o partido no poder, está a porcaria que está. Saiu lá do princípio; este partido que está no poder não é o que nós criamos. Era um partido com outro objetivo. Não era fazer essas besteiras que são feitas. (Adão)

Minha posição é a seguinte: eu sempre estou com a esquerda do partido. Ou seja, aquela ala do partido que defende, que os tradicionais do partido, os "donos da verdade", costumam tratar a gente de dinossauro. "Você não conseguiu acompanhar a evolução do tempo, que hoje os tempos são modernos, você tem que fazer aquilo $e$ isso". Eu não abro mão dos meus princípios. Lá nos anos 70 eu era trabalhador, e hoje em 2006 eu continuo trabalhador. Nos anos 70 eu recebia salário. Hoje eu continuo recebendo salário. É a mesma coisa. Se eu comia feijão naquela época, eu continuo comendo feijão hoje. Se eu morava num casa humilde naquela época, hoje eu moro em uma casa humilde. Eu não deixei de ser trabalhador em momento nenhum. Não posso abrir mão dos princípios de quando nós criamos, ou o Lula criou, um sindicato de resultado, um sindicato progressista. Nasceu da discussão com o Lula. Quem trouxe isso pra ele, eu não sei te explicar. Como ele conseguiu, e nós conhecemos a história do Lula, de onde ele veio, o que ele fez e essa coisa toda, com certeza alguém o trabalhou muito bem pra formá-lo. Foi um cara inteligente pra fazer o que ele fez, não dá pra negar. Hoje, honestamente, não comungo com muita coisa que ele faz, e principalmente os grandões do partido fazem. Não estou de acordo de forma nenhuma. (Adão)

Outros depoentes enxergam o Sindicato e o Partido de forma diferente. O fato de Lula, antigo presidente do Sindicato, ser hoje presidente da República, representa um avanço, representa a conquista que é fruto daquelas greves.

Na realidade o Sindicato dos Metalúrgicos foi, é e continuará sendo uma escola para a gente. Eu acredito nisso porque muda a direção, mudam os diretores e a gente vê que ele mantém um padrão de articulação, como exemplo para os outros, sem medo de... errar todo mundo erra, né? Mas eles têm essa força e a coragem de estar mudando todo o conceito da história do sindicalismo no Brasil. (Wilson)

E a gente vê que hoje a empresa se adaptou. Poucas hoje não fizeram isso. Mas a maioria das empresas respeitou essa organização. E hoje os comitês sindicais e as comissões de fábricas, antes de fazer qualquer pressão, ou qualquer greve, elas formulam propostas, levam para a empresa, sentam e discutem. Na época, não. $\mathrm{Na}$ nossa época de militante sindical a empresa não aceitava discutir. Por isso que tinha 
muita greve. A gente levava uma pauta e muitas vezes eles nem aceitavam a pauta. Teve caso de diretor da empresa rasgar a pauta na frente do dirigente sindical. Hoje a mudança foi muito grande. Mas não ficou fácil! Ficou mais difícil. Porque a pessoa, o próprio sindicalista hoje tem que estudar. Ele tem que ter uma formação. Para ele elaborar um documento, para ele elaborar algumas coisas, para ele ter propostas, ele tem que fazer por escrito e entregar para a empresa. Então não é que ficou fácil. $O$ pessoal fala: "Ora, hoje não tem mais greve”. A empresa também foi se adaptando às coisas. Viram que o próprio trabalhador tem razão no que ele reclama. Agora, entra em debate, discute. Algumas empresas ainda fazem greve, porque o patrão ficou lá atrás, ainda está muito atrasado. Mas a discussão, o debate, isso faz parte da categoria. E sindicato é lei. Agora, muitos por aí não têm esse entendimento, que tem que existir o sindicato. Hoje o sindicalismo é um sindicalismo moderno. (Wilson)

Eu me lembro da questão da comissão de fábrica. Comitê sindical de empresa, comitê sindical de aposentados. Muitos diretores daquela época estão no governo, inclusive o presidente Lula. Então acho que tudo cresceu. (Dimas)

Mas valeu a pena. Acho que nossa categoria metalúrgica, e vamos falar trabalhadores, evoluiu muito de 78 para cá. Agora com esse governo a gente tem mais diálogo, mais contato com eles para poder negociar. Antes nem abertura tinha. Hoje tem uma abertura. E agora, nesse momento, acho que a gente está passando por uma fase muito boa. É uma pena que é o último mandato do Lula. Gostaria que tivesse mais um mandato. Até para dar prosseguimento melhor das coisas. (Dimas)

Mesmo Rafael, que não participou das greves, tem um ponto de vista positivo sobre a evolução do Sindicato. Aponta o Sindicato como um aconchego em tempos que com o capitalismo, não tem o que fazer:

De qualquer forma, o Sindicato só ajudou, não prejudicou. Se um país não for sindicalizado, ele não tem como sobreviver. Principalmente por causa do capitalismo. [...] Quando temos um sindicalismo, temos um retorno. Com o capitalismo, não temos o que fazer. Vai embora, não tem mais retorno, e assim por diante. E me admira que esse Sindicato não tinha esse prédio, não tinha nada aqui, em 1963, isso que era praticamente um deserto. Você acha que deixei de pagar o Sindicato? Não. Eu sempre paguei o Sindicato. Os companheiros que trabalhavam comigo, que eram minha equipe, falava para eles: "Vocês podem fazer o que quiser, mas na realidade com o Sindicato o futuro nosso é mais aconchegante. Melhor que ficar na dependência dos outros, pedindo”. (Rafael) 


\subsubsection{Lula}

Lula chegou à presidência da República. E é inevitável, para aqueles que conviveram com ele pessoalmente, fazer comparações daquela pessoa que conheceram na condição de metalúrgico sindicalista com essa que é hoje presidente.

Adão quase o isenta de culpa por agir contra os princípios defendidos no período das greves e da fundação do PT. Mas diz que a melhor escolha seria não ter entrado em um sistema onde tem que seguir uma certa cartilha para não ser excluído.

Hoje você tem um presidente da República que veio do Nordeste, que passou por fábrica, que passou pelas repressões. Está presidindo a nação, entre aspas, porque ele tem que falar o que outras pessoas querem. A gente sabe, tenho muita clareza disso. $O$ que o Lula aplica hoje não é o que está na cabeça dele, é o que mandam ele fazer. Porque eu conversei com o Lula várias vezes. Ele morou aqui, foi vizinho meu. Aquele ponto onde você desceu, aquela primeira rua pra lá, ele morou ali seis meses. Depois morou ali no Maristela, depois foi pra outro lugar. Em várias reuniões que eu tive com ele, a linha de raciocínio dele é totalmente oposta ao que ele está fazendo hoje. Agora a gente já faz algumas avaliações que a gente sabe, que ou ele faz assim, ou ele sobra. A gente chega até a avaliar que talvez fosse melhor ele sobrar, que estar fazendo tanta besteira, assinando embaixo todas as trapalhadas que estão acontecendo. (Adão)

A imagem que se faz de Lula é muito forte. Sua ascensão como sindicalista significou muito para os trabalhadores na época. Adão lembra com emoção de uma passagem:

Teve uma vez que estávamos em uma manifestação em São Bernardo, lá na Vila Euclides, e parece que o Lula já tinha ganhado uma popularidade muito grande. E foi muito emocionante o acontecimento, e de repente sai uma foto na "Folha de São Paulo" que mostrava o Lula lá com o microfone e aquela multidão de gente ouvindo ele. Se tornou um grande líder a partir daí. Todo mundo atento, seguia rigorosamente as orientações dele, porque percebeu que o cara tinha umas idéias que levavam a gente a algum lugar que a gente desejava. Se tornou uma pessoa muito importante para nós. A nível de sindicalista, é o que o Brasil não teve e não sei se vai ter um como esse cara. (Adão) 
Rafael avalia que Lula está com o capitalismo, o que é inevitável, em seu ponto de vista. Ainda assim, acha que Lula representa a melhor opção para o cargo de presidente da República.

O presidente da República, o Lula, que naquele tempo era totalmente diferente, participava dos movimentos. Ele que começou as reivindicações. Apesar de hoje estar com o capitalismo. Com o capitalismo não pode mexer, senão faz uma revolução total. Então quem viu naquele tempo, e quem vê hoje... mudou. Mudou. De qualquer forma de todos os presidentes que nós tivemos, ainda ficaria com ele. Hoje nós estamos aí convivendo com os sem-teto, com os sem-emprego. (Rafael)

Reinaldo também vê Lula de forma diferente em relação àquele que era presidente do Sindicato, e com quem tinha muito contato pessoal. Mas Lula abre mão, para Reinaldo, de aspectos ligados a um campo mais pessoal do que político.

Ele tinha uma liderança perante os metalúrgicos de São Bernardo que era coisa fora do comum. Fora de série mesmo. Nasceu para a coisa mesmo. Não é à toa que um dia chegou à presidência da República. E repetiu o mandato. Ganhou bem. Foi quatro anos, mais um agora. Cinco anos. Se não o pegaram e mandarem embora, ele vai até completar oito anos de mandato. Um operário da Vilares. [...] Torneiro da Vilares. Uma firma que fazia peça de navio. No Vergueiro, ele trabalhava. Na hora do almoço, os colegas falavam que ele subia em cima das coisas e falava: "Olha, vou fazer um discurso. Vocês fiquem escutando aî”. Ele gostava muito de tirar um sarro dos outros. Era brincalhão. Gostava de dançar. Uma pessoa absolutamente normal. Eu não sei nem como é que ele está hoje. Porque hoje ele não faz nem o que ele quer. Mandam ele fazer isso. Os juízes e promotores mandam ele fazer aquilo outro. Ele gosta de andar sem gravata. Não pode mais, tem que ser com gravata. Aí já colocam gravata nele. Ele hoje está vivendo como um manequim. Os caras chegam nele e falam: "Você vai para Brasília. Você vai para a Argentina. Tem não sei o quê lá no Hugo Chávez. Tem não sei o quê lá na França”. E hoje não se governa. Ele trabalha para os outros, trabalha para o Brasil. Não é que pode acordar, escovar os dentes, tomar o café e falar: "Não vou trabalhar hoje. Não vou em tal lugar. Vou arrumar o carro e vou à praia”. Não. Acabou a vida dele. Ele tem que seguir aquele cronograma. Hoje é dia disso, amanhã é dia de não sei o quê. É bom, mas ao mesmo tempo o camarada perde a liberdade. (Reinaldo) 


\subsubsection{Situação social}

Alguns depoimentos mostram uma avaliação de melhora da vida do trabalhador e mesmo da situação social mais geral do país, melhora essa ligada às greves.

Para Wilson, as empresas se convenceram que é direito do trabalhador ser tratado com dignidade.

A gente brigou muito na Forjaria. Melhores condições de trabalho. A gente conquistou o macacão. A gente passou a não pagar mais o macacão, o sapatão. E quando rasgava, a gente ia lá e trocava. Então houve uma certa mudança. Tivemos muitas conquistas na Forjaria São Bernardo. A gente falava: era a idade da pedra. Você tem que trabalhar com aquilo que o pessoal determina. Então, com essa mudança, a gente acabou conquistando muita coisa. Hoje tem empresa que lava até a roupa dos funcionários. Mas naquela época, além de lavar a roupa, a gente tinha que pagar por ela. Então a gente teve essa conquista. Houve uma mudança muito grande. O layout da empresa também mudou muito. A partir do momento que o Sindicato começou a entrar dentro da empresa, foi ajudando a mudar o layout, para ficar muito mais tranqüilo para as pessoas trabalhar, para trabalhar mais folgado. Antes era uma máquina em cima da outra. Houve algumas idéias dentro do Sindicato que acabaram em uma mudança no layout da empresa. (Wilson)

Muita coisa mudou. O respeito aos trabalhadores, que não tinha. Antes das greves, a própria chefia batia no peito e falava: "Eu te mando embora a qualquer momento". Xingava. Teve caso que a gente soube de chefe que dava tapa na cara do operário. Após a greve isso foi mudando. O trabalhador passou a ter direito, passou a conversar, passou a opinar. Passou a ter uma série de coisas que antes ele não era ouvido. Antes ele dava opinião para melhorar, e o pessoal não queria melhorar porque dizia que trabalhador não tinha que opinar, tinha que trabalhar. E o respeito ao trabalho, ao trabalhador, hoje, as empresas entendem. Elas procuraram melhorar seus quadros de RH, de chefia. Então, fazer um trabalho em grupo, fazendo cursos com chefias. $O$ modo de tratar o trabalhador. Ele vivia mais na fábrica que em casa, então seria uma mudança necessária. Esse respeito foi uma grande mudança que houve com os trabalhadores. (Wilson) 
Dimas ao comparar a combatividade dos trabalhadores da época com a de agora, atribui ao momento político atual a falta de necessidade de se fazer greve.

O pessoal naquela época enfrentava muito mais que agora. Mas também devido às condições daquela época. A gente sabe que hoje mudou, mudou completamente. Naquela época a gente sofria uma repressão que a gente tinha que desbloquear. Então foi um movimento muito bom. (Dimas)

O que eu queria falar é o seguinte: agora não está mais havendo muitas greves. Por que não está havendo mais greves agora? Porque esse governo tem mais diálogo. Negociação. O ministro da previdência é nosso, que foi ministro do trabalho, que é o Luiz Marinho. Temos o presidente. E temos vários canais de comunicação agora. (Dimas)

Adão, ao falar das consequências das greves para a política nacional, pondera as conquistas dos trabalhadores, mas revela uma insatisfação em relação àquilo que considerava um horizonte utópico.

Todos os direitos que nós conquistamos com esses esquemas que estou te falando, não foi dado de graça. Foi na porrada, foi no grito, foi na paralisação, na mobilização, não foi fácil, não. Hoje você negocia até participação de lucro. Você nem sabia o que era lucro, hoje você faz discussão de participação de lucro, de resultados. Mas é fruto de lutas do passado. (Adão)

Foi uma abertura que se conseguiu como conseqüência das greves também. Houve uma contribuição muito grande pra destruir o poder autoritário. Essa coisa que a gente chama de sociedade democrática não tem nada de democracia ainda, na prática não é real. O fato de você poder vir aqui conversar comigo não é uma democracia total, os direitos ainda estão muito longe de ser respeitados. Mas também eu julgo que essas conquistas estão relacionadas com os resultados das greves. Isso vendo por um lado político, positivando um pouco a questão da sociedade. (Adão)

Todos os entrevistados fazem algum tipo de comparação entre o passado e o presente. As greves se configuram como um importante momento da história do país. Um dos ramos da fundação do Partido dos Trabalhadores sai do movimento sindical do ABC. Lula, então presidente do Sindicato, ocupa atualmente o cargo de presidente da República, eleito por esse mesmo partido. Ou seja, há um elo entre as greves e o momento político atual. 
No entanto, notamos diferentes formas de julgar esse elo por parte dos depoentes. A maioria deles enxerga uma evolução social e política. A exceção de Adão que vê avanços nos direitos conquistados, mas longe do ideal. Como vimos no capítulo anterior, a existência de um horizonte utópico que leva em conta o fim da exploração de classes está presente em seu depoimento, o que nos leva a crer no ceticismo da comparação entre passado e presente.

\subsection{Temporalidade nos depoimentos: os caminhos da memória}

Dificilmente tenderemos a acreditar que a memória reconstrói os fatos passados de maneira retilínea. Não esperaríamos que o metalúrgico grevista do $\mathrm{ABC}$ desse seu depoimento da seguinte forma: "Em 78, foi assim. Em 79, foi assim porque em 78 foi assim. E em 80 foi assim porque em 78 e 79 foi assim".

Notamos idas e vindas nos depoimentos aqui colhidos. Alguns desses caminhos percorridos pela memória são interessantes.

Notemos como alguns valores políticos e sociais foram sendo construídos ao longo da trajetória de Adão. Ele narra um episódio de negociação de salário com seu chefe, que se deu no início de sua vida de metalúrgico.

O salário estava tão baixo, foi até na época que eu comprei esse terreno aqui, onde está a casa que a gente mora. Você imagina: uma mulher, uma filha, a filha meio doente, o salário baixo, pagando prestação e aluguel. A coisa estava pegando feia mesmo pro meu lado. Falei: "Bom, tenho que brigar com esses caras pelo salário. Não tem jeito”. E eu tinha informação que o serviço que eu estava executando, tinha que ter pelo menos umas cinco vezes mais o salário que eu estava recebendo. Falei pro chefe, ele me enrolou. Falei pro gerente, e ele me enrolou também. E essas enrolações aí, de um chefe, pro gerente, até eu chegar no gerente da empresa, isso rolou quatro meses. [...] Aí cheguei no presidente da empresa. (Adão)

Era uma época em que Adão não conhecia a negociação coletiva, portanto, ele narra a negociação sem mencionar qualquer espírito coletivo. Ele resolveu seu problema indo conversar, sozinho, diretamente com o presidente da empresa. 
Foi depois de passar por formações no Sindicato e nas comunidades operárias ligadas à Igreja que Adão pôde conscientizar-se das lutas coletivas. Isto é, temporalmente, este episódio se localiza "antes" de sua formação política, o que pode fazer com que seja narrado sem um crivo crítico.

Chama a atenção também a vivacidade de algumas narrativas, como as que seguem:

E uma coisa, que não lembro se foi no ano de 80. A última grande greve mesmo foi em 80. Não sei se foi 79 ou 80. Saíram, ninguém sabe quem fez isso. A categoria estava um pouco oscilante. Então estava oscilando, vai para a greve, não vai, aquela coisa. E aí de madrugada soltaram um panfleto nas portas das fábricas, dizendo assim: "Eu amo meu patrão”. [risos] Aí o pessoal pegava aquela papel, olhava assim, e jogava fora. Amassava e ficava revoltado. Aquilo deu impulso na greve porque ninguém queria amar o patrão, todo mundo ficou revoltado [risos]. Aí surgiu a greve. Em não estou lembrando se foi em 79 ou se foi em 80. Mas foi um fato que a gente lembra até hoje. Aquele comentário dentro da fábrica. E aí perguntavam: "Você ama seu patrão, né?”. [risos] Muito boa essa aí. (Wilson)

Me chamavam de China. "Vem aqui, China! Você está com saudade de mim?”. Eu subia lá. Meu serviço era produção. Quatro pessoas dependiam do meu serviço. Eu fazia "pá, pá, pá”, terminava logo e ficava tranqüilo. Aí eu pegava a prancheta, subia, e os caras: "China, vem aqui. Tem uma máquina assim e assim”. O feitor me tirou desse serviço: "Você está andando muito!", "Estou andando, mas todo mundo está trabalhando. Eles dependem do meu serviço". Aí o feitor me tirou do serviço, e me mandou limpar painel. Falei: "Tá bom". Concordei para não brigar. Pegava o cabo de vassoura e colocava uma estopa. "China, como está indo?" "Está indo. Devagar, mas está indo". Era o chefão. Aí ele olhou para mim: "Ah, pô, você não tem jeito, não! Vem para cá. Volta lá para o seu serviço”. [risos] Aí voltei para meu serviço. Eu controlei minha conduta. Porque eu fiz isso? Se a pessoa perder a conduta, brigar, é mandada embora sem direitos. "Você está enrolando aí!", "Estou trabalhando. Trabalhando do meu jeito". Era um cara grandão, media quase dois metros. Magrinho ele. Ele usava uma capa amarela. "Vem cá, Nelson". Andava bem devagar. Ele reclamava. "Pô, não sou obrigado a correr atrás de você. Eu tenho a perna curtinha, você é grandão”. (Nelson)

Wilson, quando perguntado sobre as reivindicações do movimento grevista, conta essa história do panfleto provocativo. E Nelson, quando perguntado sobre as condições de higiene e segurança na fábrica, conta como resistiu a uma transferência de função não desejada. São fatos carregados de sentido para eles. Benjamin (1994) fala da relação ingênua entre narrador e ouvinte como sendo dominada pelo interesse em conservar o que foi narrado. 
"Contar histórias sempre foi a arte de contá-las de novo." (BENJAMIN, 1994, p. 205). Adão repete algumas histórias por algumas vezes durante a entrevista, o que poderia ter acontecido com outros entrevistados, mas a entrevista com Adão, como já foi visto, se deu em condições diferentes das outras cinco. A história da carne estragada, da água contaminada e do filho que conheceu com alguns dias de idade porque não podia abandonar o movimento grevista (apesar que esta última parece carregar certo sentimento de culpa), são relatos recontados em alguns momentos da entrevista.

Reinaldo, o mais velho dos depoentes, é o que menos se prende ao roteiro. A memória daquele cuja vida não está mais tão voltada para o presente, como uma atividade profissional, aparece de forma mais espontânea e fluente (BOSI, 1994). "A memória dos velhos pode ser trabalhada como mediador entre a nossa geração e as testemunhas do passado." (BOSI, 2003, p. 15). Reinaldo nos conta que São Bernardo já foi a capital dos móveis, antes de ser a capital dos automóveis. E como ele jogava futebol! Lula era um grande brincalhão, ele não gosta de usar gravata. São poucas as vindas de Reinaldo para o presente. Ele faz a mediação entre as gerações.

\subsection{Um elo entre o passado e o futuro}

Assim como os depoentes enxergam o presente como consequência de um passado do qual participaram, o futuro não está desligado dessa trama.

O futuro é visto por Adão com preocupação. Muitos direitos foram conquistados, mas estão sendo esquecidos. O futuro está na mão das novas gerações. Adão conta que sempre conversa com sua filha, que é educadora, sobre sua responsabilidade com as novas gerações. Responsabilidade essa que Adão também reconhece em si ao continuar militando em movimentos de bairro. Ao mesmo tempo há um ceticismo e uma certa sensação de missão cumprida.

E eu pretendo até acompanhar um pouco, mais através da Associação dos Metalúrgicos Aposentados. Não tenho a ilusão de fazer muita coisa, não. Eu já sei até qual é o pessoal que está lá, como age, essa coisa toda. É mais pra administrar plano de convênio médico, colônia de férias. Também, pro pessoal que já está aposentado, 
não sei como investir muito. Quem fez, fez. Quem não fez, aposto que não vai fazer. (Adão)

Adão reconhece avanços e teme retrocessos em relação às conquistas dos trabalhadores:

Eu vejo, com muita preocupação agora, até saindo um pouco da sua pergunta, o desmonte dos direitos que nós conseguimos. Esses direitos nós não podemos nem pensar em abrir mão deles. Olha, muitas vidas se foram. Mortes ocorreram. Mortes lentas. O que é morte lenta? Aquele cara que ficou excluído do mercado pra nós está em um processo de morte lenta, porque ele não terá condições de se sustentar mais. A família dele vai começar a entrar em degradação porque não tem recursos pra se manter. Aí, dependendo da maneira da família dele, começa até a sobrar, a ser excluído da própria família. "Você já está velho e não está conseguindo arrumar mais porcaria nenhuma, você arrumou um monte de treta lá fora, está desempregado, agora vai ficar enchendo o saco”. Esse é um grande problema que a gente está vivendo, dá pra perceber isso nitidamente dentro da sociedade. É muito complicado. (Adão)

Dimas lamenta que o mandato de Lula na presidência da República esteja chegando ao fim. Talvez o ápice das consequências das greves metalúrgicas seja, para ele, o fato de um metalúrgico do $\mathrm{ABC}$ ter chego a tal cargo político, onde tem oportunidade de defender a causa dos trabalhadores.

É uma pena que é o último mandato do Lula. Gostaria que tivesse mais um mandato. Até para dar prosseguimento melhor das coisas. Vai entrar um outro que a gente não sabe quem vai ser. Talvez não siga a mesma linha. Muitos falam que não está indo bem. Mas eu acho, nós achamos que está indo bem. A opinião se diverge porque tem muita oposição, que sempre faz o jogo do contrário. (Dimas)

Já Reinaldo fala de sua condição de idoso. Compara-se a um motor de automóvel, daqueles tantos motores que ajudou a fabricar na Volkswagen.

Esse velhinho aqui... tenho 84 anos. Se eu não morrer daqui até o fim do ano, já viu. Danço, nado, gosto de passear, vou à praia, faço tudo. Mas acredito que uma hora ou outra isso acaba, acaba tudo. Eu não acredito mais muito em mim. Um carro novo, o 
motor é uma beleza. Você não vê sinal disso, sinal daquilo, não precisa de conserto, não precisa de nada. Hoje eu estou todo dia no médico, cara. Nós somos como um motor: as peças vão se desgastando, estragando, ficando velhas, se deteriorando. Assim são as pessoas. Eu pulava uma mesa dessas [mesa que estava na sala onde a entrevista foi realizada], hoje não faço nem metade. Não consigo. (Reinaldo)

O que redime sua vida que está chegando ao fim é a oportunidade de lembrar.

Tomamos muita carreira dos soldados aqui. Vinha um, tudo bem. Vinham dois, tudo bem. Quando juntavam três ou quatro a polícia já chagava e "Ô, não pode! Nada de rodinhas aqui”. Se você insistisse, eles ameaçavam e você tinha que sair correndo. E eu já tinha esquecido tudo isso. Quando vocês aparecem por aqui, a gente volta a se lembrar. Era um tempo bom. A gente era bem mais novo. $O$ ano de 80 já está bem lá atrás. 70 então, nem se fala. Estamos hoje em 2007. E é bom que a gente lembra de alguma coisa, passa a viver de ilusão, de algumas coisas daquele tempo. É muito bom. E graças a vocês também. Vocês são um bem para nós. Lembrar de alguma coisa do passado é muito bom. (Reinaldo)

Já Wilson marca o elo de gerações no Sindicato dos Metalúrgicos.

$O$ que a gente praticamente vê é que a direção do Sindicato hoje é formada praticamente pelos filhos dos metalúrgicos, dos antigos diretores. E a gente vê o seguinte: aquela união, aquele debate, aquelas conversações que tinha, a vontade de mudança, tudo isso continua. Dá a mesma seqüência, o mesmo tom. A gente vê que a escolha da formação de chapa, a escolha da direção, vem vindo em um patamar de honestidade, de igualdade, de companheirismo. Isso a gente vê no Sindicato dos metalúrgicos. Eu não vou dizer que isso acontece nos outros, porque eu não tenho a convivência. Mas a gente vê que esse Sindicato aqui mantém esse padrão de discussão, que vem dentro daquele patamar que o Lula desenvolveu na época, que era não ficar só enfiado dentro do Sindicato, mas ir para a base, discutir com a base. E a base sabe quem são os dirigentes sindicais. Então, um vai para a porta da empresa do outro. Faz aquele revezamento. Não precisa gravar todos os dirigentes. Mas pelo menos a grande maioria o pessoal fica conhecendo. Isso é uma coisa que o Sindicato ainda conserva, essa unidade da diretoria. $O$ reconhecimento da peãozada com o dirigente sindical. (Wilson)

Hannah Arendt (2000) discorre sobre a quebra do elo entre o passado e o futuro. Ao comentar a resistência francesa durante a Segunda Guerra Mundial, a autora refere-se a um 
tesouro que tiveram em mãos enquanto mantiveram constituído um domínio público para resolver os problemas urgentes que apareciam durante a guerra. Esse tesouro, que os franceses não souberam nomear à época, era a liberdade decorrente do poder da iniciativa, da criação de um espaço público.

Este tesouro desapareceu logo após a guerra, sem que pudesse ser guardado e conservado - desaparecimento recorrente, segundo a autora, quando se trata das grandes revoluções. Não houve nenhuma tradição, nenhuma luz do passado, que pudesse ter previsto o aparecimento de tal tesouro. "Nossa herança foi deixada sem nenhum testamento", com essa citação de René Char começa o prefácio de "Entre o passado e o futuro" (ARENDT, 2000, p. 28). O tesouro, herdado de ninguém, não foi guardado no baú da memória, e

somente em raríssimas ocasiões a mente humana é capaz de reter algo inteiramente desconexo. [...] O ponto em questão é que o 'acabamento' que de fato todo acontecimento vivido precisa ter nas mentes dos que deverão depois contar a história e transmitir seu significado deles se esquivou, e sem este acabamento pensado após o ato e sem a articulação realizada pela memória, simplesmente não sobrou nenhuma história que pudesse ser contada. (ARENDT, 2000, p. 31-32).

O desfalecimento da tradição é próprio da época moderna, que a deixa de lado em nome do progresso. Weil (1996) define o enraizamento nesta célebre frase: “O ser humano tem uma raiz por sua participação real, ativa e natural na existência de uma coletividade que conserva vivos certos tesouros do passado e certos pressentimentos do futuro." (p. 411). O enraizamento é uma das necessidades mais importantes da alma humana, e se alimenta da participação nos grupos aos quais a pessoa pertence e também da troca com os grupos aos quais não pertence.

O desenraizamento é dos piores males que assolam a humanidade. No caso dos operários, são tolhidos de qualquer participação real nos processos de produção, a não ser aquela (se é que se pode chamar de participação) que os colocam como acionadores das máquinas.

Quais são os tesouros do passado e os pressentimentos do futuro que os metalúrgicos do ABC guardam? Eles existem?

Adão lembra com emoção dos companheiros que morreram na luta, especialmente de Santo Dias da Silva. 
Até que no ano de 79 o bicho já pegou mais feio. Bastante gente foi presa, e a intervenção era imediata da polícia. Decretou greve, batiam um fio, e a tropa de choque estava ali todinha, como se a gente fosse um bando de bandido. Isso ocorreu durante o ano todo, e eles fecharam o ano com uma sacanagem muito grande, que gostaria até de estar lembrando da morte do metalúrgico Santo Dias da Silva, que se completa agora 26 anos. Foi baleado pelas costas pelo soldado Herculano, na porta da empresa Sylvania em Santo Amaro. Ele era uma pessoa muito ponderada, muito consciente. Era querido por todo mundo, no lugar onde ele trabalhava, no lugar onde ele morava. A gente sabia que ele tinha uma ligação muito grande com a Igreja Católica, ajudava com essa coisa da evangelização, onde entra a formação. E nesse dia 30 de outubro de 1979, uma greve já bem inflamada na Sylvania, e estava pra acontecer. Porque a polícia estava de um lado, o pessoal já não estava agüentando do outro, e em um determinado momento, quando o Santo Dias levantou a mão pra sinalizar aos grevistas pra pedir calma, a tropa da Polícia Militar que estava atrás tirou a vida dele. Atirou pelas costas. E deu um trabalho. Como eu falei que sumia muita gente, com o Santo Dias não foi diferente. Logo que o soldado Herculano executou o serviço... lógico que não se poderia atribuir somente a ele, é um coletivo que estava ali, era uma tropa, e alguém estava comandando. Alguém tinha que atirar, e esse alguém foi o soldado Herculano, e não podemos esquecer esse nome de forma nenhuma, porque ele tirou estupidamente a vida de um militante. [...] Completou agora 26 anos, e todo dia 30 de outubro, no mesmo horário, que foi às duas e pouco da tarde, ainda se reúne um pessoal no local do assassinato dele e cada um manifesta sua solidariedade da sua própria maneira. Nada é imposto pra ninguém. A família dele a gente sempre tem contato, a Dona Ana Dias, a filha e as três netinhas. Sábado ainda estive com eles. (Adão)

"As lutas pela memória, eis algo que todos temos conhecimento de causa." (BOSI, 1994, p. 411). Adão faz questão de contar essa história de modo que aqueles que a escutarem não a esquecerão. Um militante morreu em greve. A reunião com a família não se trata apenas de manifestação de solidariedade, mas da construção de uma memória que jamais se perderá no tempo.

Os metalúrgicos que lutaram nas greves sabem, em algum nível de consciência, que estão deixando um legado para as gerações futuras. Adão e Wilson contam sobre a experiência de ter dado o depoimento.

Mas pra mim foi muito bom, foi muito bom isso aí. Acho que é uma maneira de, quem sabe, daqui a alguns anos, se alguém se interessar, tornar isso... você vai escrever isso, né? Quem sabe daqui a algum tempo alguém pegar isso, ler e falar: "Mudou? Alguém já trabalhou essa mudança há muito tempo. Não mudou? Mas alguém já 
trabalhou há muito tempo tentando mudar, mas esse bicho é feroz, não tem muito jeito com ele, não”. Se várias pessoas pegam o texto pra ler, cada um vai interpretar de um jeito. Mas o que fica bem claro de tudo isso aí é que a gente está falando de tudo aquilo que a gente viveu no dia-a-dia. (Adão)

Eu achei que foi bacana. A gente relembra o passado que a gente viveu. Eu costumo sempre falar para as pessoas o seguinte: faça sua história, não deixe que os outros contem. Porque quando o outro conta, ele não conta direito, ele conta mal. Então construindo a sua, você está sempre contando aquilo que você viveu, que você presenciou. Isso é fundamental. Você dar a entrevista, o depoimento, ver aquilo pelo que você passou, a mudança que teve, tudo isso é uma coisa gratificante para a gente, porque a gente está aqui para dar o testemunho do que foi nossa vida naquele momento de greve, de trabalho, de tudo o que acontece no contexto das greves dos metalúrgicos. Então, para a gente, é gratificante quando você vem aqui e faz a entrevista com a gente. E sei que você vai levar e apresentar para algumas pessoas. Não só o meu depoimento, mas o depoimento de muitas pessoas. É muito ruim quando alguém inventa a coisa e fala para você. E é gratificante também para você quando a gente mostra tudo aquilo que a gente viveu. Tem muito mais coisas que a gente não lembra na hora. Têm momentos tristes, momentos alegres. Como eu disse, teve companheiro que morreu, teve companheiro que perdeu o braço. E a gente está aqui para contar o que aconteceu no dia-a-dia com a gente. Eu sempre falo para o pessoal o seguinte: agradeço a Deus por ter pequenas seqüelas. Eu perdi um por cento do ouvido direito e meio por cento do esquerdo. Mas eu procurava sempre me cuidar. Não tinha EPI, colocava algodão no ouvido. O pessoal perguntava: pra que isso? Porque o barulho era muito grande. Sempre usando o equipamento, chego hoje aos 57 anos e meio, graças a Deus, com saúde. Trabalhando com veneno, química, tudo. Mas a gente procurou ter cuidado para chegar a essa idade. Daqui pra lá é outra coisa. [risos] (Wilson)

\subsection{Para finalizar, uma questão}

Vimos no capítulo 6 quais são os significados que os metalúrgicos atribuem à greve. Eles são, na verdade, múltiplos. Dependem, dentre outros fatores, da vivência que tiveram na greve, e também do tipo de envolvimento.

Observamos no capítulo 7, que há uma construção coletiva da memória que atribui os significados às greves. Ao mesmo tempo, os metalúrgicos lembram com vivacidade impressionante de episódios onde eles puderam agir. 
Já no capítulo 8 pudemos perceber que as trajetórias dos metalúrgicos em um movimento político, como é o movimento grevista, depende muito da mediação de agentes formadores. A consciência da greve enquanto política depende de como o metalúrgico passa por essa formação.

Neste capítulo verificamos os caminhos que a memória faz, tendo o presente sempre como referência. Vimos também que o elo da tradição, que une passado e futuro, está quebrado na modernidade.

Pois bem, o que teriam os metalúrgicos do $\mathrm{ABC}$ para nos deixar de herança? Os depoentes relatam que ainda se encontram com os companheiros e, juntos, lembram das greves que já aconteceram a cerca de 30 anos. Esses metalúrgicos estão envelhecendo. Quem contará suas histórias no futuro?

Estariam os metalúrgicos criando uma tradição de luta para os oprimidos? Será que estes movimentos grevistas influenciarão os que quiserem lutar por justiça e dignidade? Como, concretamente, a política pode se beneficiar da memória? Essas perguntas podem nos remeter à importância da memória para a política. 


\section{REFERÊNCIAS}

A GREVE na voz dos trabalhadores: da Scania a Itu. São Paulo: Ed. Alfa-Ômega, 1979. (História Imediata 2).

ABRAMO, L. W. O resgate da dignidade: greve metalúrgica e subjetividade operária. São Paulo: Imprensa Oficial; Campinas: Ed. UNICAMP, 1999.

ANTUNES, R. L. C. A rebeldia do trabalho: o confronto operário no ABC Paulista: as greves de 1978/80. Campinas: Ed. UNICAMP, 1992.

ARENDT, H. Entre o passado e futuro. São Paulo: Ed. Perspectiva, 2000.

A condição humana. Rio de Janeiro: Forense Universitária, 2005.

BARGAS, O.; RAINHO, L. F. As lutas operárias e sindicais dos metalúrgicos em São Bernardo (1977/79). São Paulo: Associação Beneficente e Cultural dos Metalúrgicos de São Bernardo do Campo e Diadema, 1983. 1 v.

BENJAMIN, W. Magia e técnica, arte e política: ensaios sobre literatura e história da cultura. São Paulo: Brasiliense, 1994.

BOSI, E. Memória e sociedade: lembrança de velhos. São Paulo: Companhia das Letras, 1994.

O tempo vivo da memória: ensaios de psicologia social. São Paulo: Ateliê Editorial, 2003.

FREDERICO, C. A vanguarda operária. São Paulo: Símbolo, 1979.

GONÇALVES FILHO, J. M. Humilhação social: um problema político em psicologia. Psicologia USP, v.9, n.2, p.11-67, 1998. 
Problemas de método em psicologia social: algumas notas sobre a humilhação política e o pesquisador participante. In: BOCK, A. M. B. (Org.). Psicologia e compromisso social. São Paulo: Cortez, 2003.

Instrução 1 para o trabalho de campo. Texto usado na disciplina Psicologia Social I (graduação IP-USP). mimeo, [s.d].

HALBWACHS, M. A memória coletiva. São Paulo: Centauro, 2006.

MAHFOUD, M. e SCHMIDT, M. L. S. Halbwachs: memória coletiva e experiência. Psicologia USP, v.4, n.1/2, p.285-298, 1993.

MARONI, A. A estratégia da recusa: análise das greves de maio/78. São Paulo: Brasiliense, 1982.

MARTINS, H. H. T. S. Igreja e movimento operário no $A B C$. São Paulo: Hucitec; São Caetano do Sul: Prefeitura de São Caetano do Sul, 1994.

MORTADA, S. P. Memória e política: um estudo de psicologia social a partir do depoimento de militantes estudantis. 2002. Dissertação (Mestrado em Psicologia) - Instituto de Psicologia, Universidade de São Paulo, São Paulo.

RODRIGUES, I. J. A trajetória do novo sindicalismo. In: RODRIGUES, I. J. O novo sindicalismo: vinte anos depois. Petrópolis: Vozes, 1999.

SADER, E. Quando novos personagens entraram em cena: experiências e lutas dos trabalhadores da Grande São Paulo (1970-80). Rio de Janeiro: Paz e Terra, 1988.

WEIL, S. A condição operária e outros estudos sobre a opressão. In: BOSI, E. (Org.). Simone Weil: a condição operária e outros estudos sobre a opressão. Tradução de Therezinha G. G. Langlada. Rio de Janeiro: Paz e Terra, 1996. 


\section{ANEXOS}

\section{ANEXO 1 - Roteiro de Entrevista Piloto}

I. A vida fora da fábrica

- Onde você nasceu? Em que ano?

- Onde você morava na década de 70? Morava com quem?

- Quanto você ganhava? Alguém mais trabalhava na sua família? Como era o orçamento familiar?

- Você freqüentava a igreja, ou era praticante de alguma religião?

- Quais jornais ou revistas você lia na época?

- Quando você começou a trabalhar como operário? Em qual fábrica?

II. A vida na fábrica

- Em que fábrica você trabalhava? Quantas pessoas trabalhavam lá?

- Qual função você exercia na fábrica? Como era este trabalho? Você pode descrever o que você fazia?

- A que horas você entrava para trabalhar? E a que horas saía? Quantos intervalos para descanso você tinha? Duravam quanto tempo? O que fazia durante os intervalos?

- Quem eram seus companheiros de trabalho? Eles eram do mesmo setor que você? Vocês se encontravam fora da fábrica, para outras atividades (lazer, sindicato etc.)?

- Havia alguém que supervisionava seu trabalho? Quem era? Como era sua relação com esta pessoa?

- Quem eram os patrões? Como eles eram? Você tinha contato pessoal com eles?

III. O sindicato

- Você era filiado a algum sindicato? Qual? Onde ficava?

- Quem eram os diretores/dirigentes do sindicato? Como você se relacionava com eles?

- Como funcionava o sindicato? Quais eram as discussões e debates que o sindicato realizava?

- Os diretores do sindicato pertenciam a algum grupo ou partido político? Qual? Você também fazia parte de algum destes grupos, ou simpatizava mais com algum deles?

- Você lembra de publicações do sindicato, como jornais ou boletins? Você tem alguma destas publicações guardadas?

IV. As greves

a) greve de 1978

- Como era o clima dentro da fábrica nos meses que antecederam à greve de 1978? As pessoas falavam em greve? Havia uma repressão forte para que não houvesse manifestações políticas dentro das fábricas?

- Como começou a greve de 1978? O que levou os trabalhadores a pararem de trabalhar e aderir à greve? Quais eram a reivindicações?

- Você aderiu à greve imediatamente? $\mathrm{O}$ que levou você a aderir à greve? Todos os seus companheiros aderiram?

- Como foi a greve? Como eram as assembléias? Onde elas aconteciam?

- Como era a ação do sindicato na greve? Como era a relação do sindicato com as bases?

- Quem eram as lideranças da greve? Como estas pessoas agiam? 
- Quais fábricas aderiram à greve? Como era o contato com os trabalhadores das outras fábricas?

- O que sua família achava da greve? Eles apoiavam as reivindicações? Eles tinham medo da repressão, ou que você fosse preso pela repressão?

- O que a mídia publicava sobre a greve?

- Quanto tempo durou esta greve? Como ela terminou? Quais foram os resultados? Houve acordo com o patronato? Houve conquistas do movimento grevista? Quais?

- Como foi voltar ao trabalho?

b) greve de 1979

- Qual era o clima na fábrica entre a greve de 1978 e a de 1979? Você e seus companheiros conversavam sobre a greve ocorrida e a realização de uma nova?

- Como começou a greve de 1979? Você chegou a aderir? Como foi sua adesão à greve?

- Quais eram as reivindicações nesta greve? Eram as mesmas da outra greve?

- Como se desenrolou esta greve?

- Como era a ação do sindicato na greve? Como era a relação do sindicato com as bases?

- Quem eram as lideranças da greve? Como estas pessoas agiam?

- Quanto tempo durou esta greve? Como ela terminou? Quais foram os resultados? Houve acordo com o patronato? Houve conquistas do movimento grevista? Quais?

- Como foi voltar ao trabalho?

c) greve de 1980

- Qual era o clima na fábrica depois da greve geral?

- Como começou a greve de 1980 ?

- Quais eram as reivindicações nesta greve? Eram as mesmas das outras greves?

- Como se desenrolou esta greve?

- Como era a ação do sindicato na greve? Como era a relação do sindicato com as bases?

- Quem eram as lideranças da greve? Como estas pessoas agiam?

- Quanto tempo durou esta greve? Como ela terminou? Quais foram os resultados? Houve acordo com o patronato? Houve conquistas do movimento grevista? Quais?

- Como foi voltar ao trabalho?

V. Repercussões das greves

- Quais foram as repercussões das greves na vida dos trabalhadores? O que mudou depois das greves?

- Quais foram as conseqüências das greves na cidade e no resto do país?

- O que sua família achava da greve? Eles apoiavam as reivindicações? Eles tinham medo da repressão, ou que você fosse preso?

- O que a mídia publicava sobre a greve? O que aparecia nos jornais e revistas? E no rádio e na TV? Estas informações condiziam com o que você vivenciou nas greves?

VI. Finalização

- Você ainda encontra alguns dos companheiros que participaram das greves?

- Há alguma coisa que você queira acrescentar? Você se lembra de alguma coisa relevante que não tenha dito?

- O que você achou de dar esta entrevista? Como se sentiu? 


\section{ANEXO 2 - Roteiro de Entrevista}

Dados do entrevistado:

- onde e quando nasceu, é casado, tem filhos, netos

- o que faz hoje em dia

- em quais fábricas trabalhou

I. As greves

- O que você se lembra das greves das quais você participou? O que você pode me contar delas?

Temas que desejo que o entrevistado aborde:

- pauta de reivindicações

- companheiros de greve

- participação do sindicato

- repressão policial e política

- assembléias e reuniões

- volta ao trabalho

- Qual foi a primeira greve da qual você participou? Você se lembra como ela começou?

- De quais outras greves você se lembra? Você pode contar algum episódio marcante sobre a greve?

II. A vida na fábrica

- O que você lembra sobre o trabalho na fábrica?

- Qual função você exercia na fábrica? Como era este trabalho? Você pode descrever o que você fazia?

Temas que desejo que o entrevistado aborde:

- salário

- condições de trabalho (higiene, segurança)

- supervisores e patrões

III. O sindicato

- O que você lembra sobre o sindicato na época das greves?

IV. Movimentos sociais e políticos

- Você fazia parte de algum movimento de bairro ou ligado à Igreja? O que você lembra sobre esses movimentos?

- Você fazia parte de algum partido ou grupo político? O que você lembra desse partido ou grupo?

VI. Finalização

- Quais foram as repercussões das greves na vida dos trabalhadores? O que mudou depois das greves?

- Você ainda encontra alguns dos companheiros que participaram das greves? Vocês conversam sobre as greves, relembram os acontecimentos da época?

- Há alguma coisa que você queira acrescentar? Você se lembra de alguma coisa relevante que não tenha dito?

- O que você achou de dar esta entrevista? Como se sentiu? 